\author{
UNIVERSIDADE DE SÃO PAULO \\ FACULDADE DE FILOSOFIA, LETRAS E CIÊNCIAS HUMANAS \\ DEPARTAMENTO DE GEOGRAFIA
}

MONICA AMENDOLA

Uma avaliação do ordenamento territorial no processo de planejamento governamental:

estudo do Rio de Janeiro

versão revisada

São Paulo 
Monica Amendola

\title{
Uma avaliação do ordenamento territorial no processo de planejamento governamental: estudo do Rio de Janeiro
}

\author{
versão revisada
}

Tese apresentada ao Programa de Pós-Graduação em Geografia Humana, do Departamento de Geografia da Faculdade de Filosofia, Letras e Ciências Humanas da Universidade de São Paulo, para obtenção do título de Doutor em Geografia Humana

Área de Concentração: Geografia Humana Orientador: Profa. Dra. Ana Maria Marques Camargo Marangoni

São Paulo

2011 
Autorizo a reprodução e divulgação total ou parcial deste trabalho, por qualquer meio convencional ou eletrônico, para fins de estudo e pesquisa, desde que citada a fonte.

Catalogação na Publicação

Serviço de Biblioteca e Documentação

Faculdade de Filosofia, Letras e Ciências Humanas da Universidade de São Paulo

A511a

Amendola, Monica

Uma avaliação do ordenamento territorial no

processo de planejamento governamental: estudo do

Rio de Janeiro / Monica Amendola ; orientadora Ana

Maria Marques Camargo Marangoni. - São Paulo, 2011.

$287 \mathrm{f}$.

Tese (Doutorado)- Faculdade de Filosofia, Letras e Ciências Humanas da Universidade de São Paulo. Departamento de Geografia. Área de concentração:

Geografia Humana.

1. Ordenamento Territorial. 2. Planejamento

Governamental. 3. Planejamento Urbano e Regional. 4. Rio de Janeiro. 5. Aménagement du Territoire. I. Marangoni, Ana Maria Marques Camargo, orient. II. Título. 
Folha de Aprovação

Monica Amendola

Uma avaliação do ordenamento territorial no processo de planejamento governamental: estudo do Rio de Janeiro

Tese apresentada ao Programa de Pós-Graduação em Geografia Humana, do Departamento de Geografia da Faculdade de Filosofia, Letras e Ciências Humanas da Universidade de São Paulo, para obtenção do título de Doutor em Geografia Humana

Aprovado em:

\section{Banca Examinadora}

Prof. Dr.

Instituição: Assinatura:

Prof. Dr.

Instituição: Assinatura:

Prof. Dr.

Instituição: Assinatura:

Prof. Dr.

Instituição: Assinatura:

Prof. Dr. Instituição: Assinatura: 
Aos meus pais,

Oswaldo (in memorian) e Luiza

Verdadeiros amigos que sempre me deram as bases necessárias para passos mais largos na vida com muito amor, confiança e dedicação.

Ao Caio,

Filho amado que sempre me dá forças para prosseguir.

À Professora Ana Maria,

De uma

incomparável sapiência e experiência, mostrava o caminho das pedras e nos momentos de insegurança, mostrou-se doce e firme. 


\section{Agradecimentos}

Meus sinceros agradecimentos a todas as pessoas e instituições que contribuíram de forma decisiva para a realização deste trabalho.

Agradeço a Profa Dra Ana Maria Marques Camargo Marangoni pela orientação, tamanha sabedoria e experiência de vida.

Meu apreço em especial às Profa. Dra. Monica Arroyo e à Geógrafa Dra. Cleide Poletto, que fizeram parte da banca de qualificação e puderam contribuir ao máximo com críticas e sugestões.

Aos colegas com os quais convivi e a todos da equipe da Secretaria de Pós-Graduação de Geografia Humana, Ana, Jurema, Rosângela, Maria Aparecida, José Firmino, pela atenção e eficiente atendimento às minhas demandas.

Aos bibliotecários de todas as universidades e instituições pelas quais passei, em especial a Rosana, Carlos e Antônio do IBGE; a Ângela do IPEA, a Teresa do IBAM; ao Rutônio da Biblioteca Nacional; a Cristiane do IPP, a Lígia e sua equipe da FGV.

À Glória, secretária e assessora do ex-Ministro do Planejamento, economista João Paulo dos Reis Velloso, que eficientemente intermediou a tamanha oportunidade de entrevistá-lo.

Ao considerável sociólogo Prof. José Arthur Rios com quem estive conversando sobre as favelas da cidade e que se disponibilizou a contribuir no que fosse necessário.

Ao CNPQ pelo apoio financeiro despendido. 


\section{RESUMO}

AMENDOLA, Monica. Uma avaliação do planejamento no ordenamento territorial: o caso Rio de Janeiro. 2011.287fls Tese (Doutorado) - Faculdade de Filosofia, Letras e Ciências Humanas, Universidade de São Paulo, São Paulo, 2011.

Esta tese avalia o ordenamento territorial urbano no planejamento da metrópole do Rio de Janeiro e de sua região de influência. O ordenamento territorial implica estabelecer conexões complexas e por vezes inusitadas. Envolto em numerosos conflitos políticos, o ordenamento territorial urbano carioca conjuga o impasse entre as expectativas da sociedade quanto ao acesso aos bens e serviços urbanos e o anacronismo dos instrumentos jurídicos, administrativos e normativos. A cidade do Rio de Janeiro, outrora capital federal (1834 a 1960), Estado da Guanabara (1960 a 1975) e, atualmente, capital do Estado do Rio de Janeiro (a partir de 1975), adquiriu numerosas peculiaridades no ordenamento de seu território. As dificuldades em estabelecer uma estrutura de planejamento urbano e regional, assim como as intervenções localizadas de elevado custo resultaram num espaço bastante segmentado e suscetível aos conflitos sociais e territoriais impeditivos para políticas públicas integradas em toda região metropolitana. A estruturação do espaço urbano carioca caracterizou-se por intensos conflitos oriundos da complexa estrutura interna de poderes sobrepostos; um conjunto de legislações urbanísticas excludentes, ineficazes no que se refere à justiça social; a intensa presença do governo federal em políticas locais; ineficiente estrutura organizativa e administrativa dos órgãos de planejamento do governo; distanciamento dos planos e programas da realidade dinâmica das relações sociais estabelecidas e principalmente pela descontinuidade das ações e políticas urbanas. Há que se considerar que hoje o ordenamento territorial deixou de ser apenas uma incumbência de um único representante político o intervir sobre o território. De modo conflituoso a proposta do ordenamento territorial vem se tornando um tema político importante ao se confrontar com o quadro de crise que se estabeleceu entre as formas e sistemas de governos centralizadores, nacionalistas e autoritários. O ordenamento territorial impõe reformas governamentais diante de uma realidade de novas repartições de poderes sobre o território, dos desafios lançados às administrações públicas e das mudanças do papel do governo no mundo de relações globalizadas.

Palavras-chave: ordenamento territorial, desenvolvimento territorial, planejamento governamental, Rio de Janeiro. 


\begin{abstract}
AMENDOLA, Monica. Uma avaliação do planejamento no ordenamento territorial: o caso Rio de Janeiro. 2011. 287 sht. Tese (Doutorado) Faculdade de Filosofia, Letras e Ciências Humanas, Universidade de São Paulo, São Paulo, 2011.

This thesis evaluates the urban land use in planning of the metropolis of Rio de Janeiro and it's region of influence. Evaluating the spatial planning in Rio de Janeiro implies establish complex and unusual bonds. Wrapped in many political conflits, the spatial planning in the state combines the impasse between the society expectations regarding the acess to the urban goods and services and the anacronism of the legal, administrative and regulatory requirements. The city of Rio de Janeiro, once federal capital (1834 to 1960), State of Guanabara (1960 to 1975) and currently capital of the State of Rio de Janeiro (from 1975 to nowadays), acquired many singularities in spatial planning. The difficulties of establishing a structure of urban and territorial planning and the located interventions of high cost resulted in a highly segmented space and susceptible to social and territorial conflits, liable to affect integrated public policies across the whole metropolitan area. The structuring of carioca urban space was featured by a deep conflicts caused by the complex internal structure of overlapping powers; a set of ineffective and exclusionary urban legislation when it comes to social justice; strong presence of the federal government in local policies; inefficient organizational and administrative structure organs of government planning; detachment of plans and remoteness of plans and programs of the dynamic reality of social relations and especially by the discontinuity of urban policies and actions. There has to be considered that today, the land use is no longer just a task of a single political representative to speak on the territory. So the proposal of the spatial planning, in a conflicting way, is becoming an important political issue against the crisis situation that has developed between the forms and systems of centralized, nationalist and authoritarian government. The spatial planning imposes government reforms against a reality of new public offices and new challenges over the territory, of challenges posed to public administrations and to the changes of the government's role on the world of global relationships.
\end{abstract}

Key-word: spatial planning, territorial development, government planning, Rio de Janeiro 


\section{RESUMÉ}

AMENDOLA, Monica. Uma avaliação do planejamento no ordenamento territorial: o caso Rio de Janeiro. 2011.287 f. Tese (Doutorado) - Faculdade de Filosofia, Letras e Ciências Humanas, Universidade de São Paulo, São Paulo, 2011.

Cette thése évalue le planning d'aménagement territorial urbain de la métropole du Rio de Janeiro et sa région d'influence. L'aménagement du territoire entraîne à établir des liaisons complexes et inusitées. Entouré des nombreux conflits politiques, l'aménagement territorial urbain de Rio de Janeiro conjugue l'impasse entre les expectatives de la societé, en ce qui concerne à l'accessibilité aux biens et services urbains, et l'anachronisme des instruments juridiques, administratifs et nomatifs. La ville de Rio de Janeiro, dans le passé, capitale federale (1834-1960), État de la Guanabara (1960-1975) et actuallement capitale de l'État de Rio de Janeiro (à partir de 1975), a acquis des nombreuses spécificités dans l'aménagement de son territoire. Les difficultés à fixer une structure du planning urbain et regional, aussi que les intervertions localisées à coût élevé ont déterminé un espace plus segmenté et susceptibles aux conflits sociaux et territoriaux qui rendent difficiles les politiques publiques integrées dans toute la région metropolitaine. La

structuration de l'espace urbain de la ville de Rio de Janeiro s'est caracterisée par des intenses conflits, issus de la complexe structure interne des pouvoirs superposés; un ensemble de législations urbanistiques d'exclusion, inefficaces en ce qui concerne à la justice sociale; l'intense présence du gouvernement fédéral dans les politiques locales; la structure inefficace d'organisation et d'administration des institutions de planning du gouvernement; les plans et les programmes éloignés de la realité dynamique des rapports sociaux fixés et, principalement, par la discontinuité des actions et des politiques urbaines. II faut considérer que, aujourd'hui, l'aménagement du territoire n'est pas seulement une tâche d'un seul représentant politique de intervenir dans le territoire. D'une manière conflictueuse, la proposition d' aménagement territorial est devenue un sujet politique important en face de la situation de crise, établie entre les formes et les système de gouvernements centralisateurs, nacionalistes et autoritaires. L'aménagement du territoire impose des réformes gouvernementeles en face d'une realité de nouvelles répartitions des pouvoirs dans le territoire, des défis lancés aux administrations publiques et aux changements des rôles du gouvernement dans le monde des rapports globalisés.

Mots- L'aménagement du territoire, développement territorial, planning gouvernamental, Rio de Janeiro 


\section{LISTA DE MAPAS}

Mapa 1 - Região Metropolitana do Rio de Janeiro - 1974............................ 134

Mapa 2 - Região Metropolitana do Rio de Janeiro - 2009 ...........................134

Mapa 3 - Áreas de Planejamento......................................................... 191

\section{LISTA DE FIGURAS}

Figura 1 - O Rio de Janeiro, sua Região Metropolitana e o Estado do Rio de Janeiro.

Figura 2 - Fundação da Cidade de São Sebastião do Rio de Janeiro - primeiro núcleo.

Figura 3 - Plano de um Trecho do Rio de Janeiro e de Niterói

Figura 4 - A Delimitação do Grande Rio de Janeiro................................ 133

Figura 5 - O Plano Agache........................................................... 148

Figura 6 - Estado da Guanabara - Regiões Administrativas - 1 ................... 157

Figura 7 - Estado da Guanabara - Regiões Administrativas - 2..................160

Figura 8 - O Plano Doxíadis................................................................ 165

Figura 9 - Áreas de Planejamento - Macrozonas de Ocupação .................. 206 


\section{LISTA DE SIGLAS}

ACRJ Associação Comercial do Rio de Janeiro

ADESG Associação dos Diplomados da Escola Superior de Guerra

ADEMI Associação dos Dirigentes de Empresas do Mercado Imobiliário

APA Área de Proteção Ambiental

APAC Área de Proteção do Ambiente Cultural

APARU Área de Proteção Ambiental e Recuperação Urbana

APP Áreas de Preservação Permanente

ARECIP Associação Regional das Empresas de Crédito Imobiliário e Poupança

BID Banco Interamericano de Desenvolvimento

BIRD Banco Internacional para Reconstrução e Desenvolvimento

BNDES Banco Nacional de Desenvolvimento Econômico e Social

BNH Banco Nacional de Habitação

BRT Bus Rapid Transit

CDE Conselho de Desenvolvimento Econômico

CDURP Companhia de Desenvolvimento Urbano da Região Portuária

CEE's Comissões Estaduais de Energia

CEDES Conselho Estadual de Desenvolvimento Econômico e Social

CEHAB-RJ Companhia Estadual de Habitação do Rio de Janeiro

CEPAL Comissão Econômica para a América Latina e o Caribe

CEF Caixa Econômica Federal

CIAT Comitê Interministerial de Ordenamento do Território

CIBPU Comissão Interestadual da Bacia Paraná-Uruguai

CIRJ Confederação das Indústrias do Rio de Janeiro

CNG Conselho Nacional de Geografia

CHISAM Coordenação de Políticas de Habitação de Interesse Social da Área Metropolitana do Rio de Janeiro

CNDU Conselho Nacional de Desenvolvimento Urbano

CNPU Comissão Nacional de Regiões Metropolitanas e Políticas Urbanas

COB Comitê Olímpico Brasileiro 
COHAB- RJ Cooperativa Metropolitana de Habitação do Rio de Janeiro

COHABs Companhias Estaduais (ou Municipais) de Habitação

COI Comitê Olímpico Internacional

CODESCO Companhia de Desenvolvimento das Comunidades

COPEG Companhia Progresso do Estado da Guanabara

CVSF Comissão do Vale de São Francisco

DATAR Delegação para o Ordenamento do Território e da Ação Regional

DEERs Departamentos Estaduais de Estradas de Rodagem

DER-GB Departamento de Estradas de Rodagem da Guanabara

DIACT Delegação Interministerial ao Ordenamento e a Competitividade dos Territórios

DNER Departamento Nacional de Estradas de Rodagem

DNOCS Departamento Nacional de Obras Contra as Secas

DNOS Departamento Nacional de Obras e Saneamento

DOT Diretoria de Ordenamento Territorial

EBTU Empresa Brasileira de Transportes Urbanos

ELETROBRAS Centrais Elétricas Brasileiras S.A.

EMATER Empresa Brasileira de Extensão Rural (uma para cada Estado)

EMBRATUR Empresa Brasileira de Turismo (antigo)

EMBRATUR Instituto Brasileiro de Turismo (atual)

EOM Empresa Olímpica Municipal

ESG Escola Superior de Guerra

EPEA Escritório de Pesquisas Econômicas Aplicadas

EPGE Escola de Pós-Graduação em Economia da Fundação Getúlio Vargas

FAFEG Federação das Associações de Moradores das Favelas da Guanabara

FAS Fundo de Apoio ao Desenvolvimento Social

FEDER Fundo Europeu de Desenvolvimento Regional

FDES Fundo de Desenvolvimento Econômico e Social

FIAT Fundo de Intervenção para o Ordenamento do Território

FIEGA Federação das Indústrias do Estado da Guanabara

FIFA Federação Internacional do Futebol 
FINEP Financiadora de Estudos e Projetos

FIPLAN Fundo de Financiamento de Planos de Desenvolvimento Local Integrado

FUNDEC Fundo de Desenvolvimento Econômico

FUNDREM Fundação para o Desenvolvimento da Região Metropolitana do Rio De Janeiro

FNDU Fundo Nacional de Apoio ao Desenvolvimento Urbano

GEIPOT Empresa Brasileira de Planejamento de Transportes

GERMET Grupo de Estudo da Região Metropolitana do Rio de Janeiro

HIS Habitações de Interesse Social

HMP Habitações do Mercado Popular

IAB Instituto de Arquitetos do Brasil

IAT Índice de Aproveitamento do Terreno.

IDEG Instituto de Desenvolvimento do Estado da Guanabara

IBAD Instituto Brasileiro de Ação Democrática

IBAM Instituto Brasileiro de Administração Municipal

IBGE Instituto Brasileiro de Geografia e Estatística

IBMEC Instituto Brasileiro de Mercado de Capitais

IPP Instituto Municipal de Urbanismo Pereira Passos

ICM Imposto sobre Circulação de Mercadorias

ILPES Instituto Latino-Americano e do Caribe de Planejamento Econômico e Social

INAE Instituto Nacional de Altos Estudos

IPES Instituto de Pesquisa e Estudos Sociais

IPASE Instituto de Previdência a Assistência dos Servidores do Estado

IPLAN RIO Instituto de Planejamento do Rio de Janeiro

IPTU Imposto Predial e Territorial Urbano

ISS Imposto sobre Serviços

ITBI Imposto sobre Transmissão de Bens Imóveis

LRF Lei de Responsabilidade Fiscal

LOADT Lei de Orientação para o Ordenamento e Desenvolvimento do Território

LOADDT Lei de Orientação para o Ordenamento e Desenvolvimento Durável do Território 
MINTER Ministério do Interior

MCT Ministério de Ciência e Tecnologia

NEURB Núcleo de Estudos Sociais para Habitação e Urbanismo

OEA Organização dos Estados Americanos

PAC Programa de Ação Concentrada

PAC Programa de Aceleração do Crescimento

PDT Partido Democrático Trabalhista

PIT-METRO Plano de Integração Metropolitano

PLANHAP Plano Nacional de Habitação Popular

PND Plano Nacional de Desenvolvimento

PNOT Plano Nacional de Ordenamento Territorial

POUSO Posto de Orientação Urbanística e Social

PRODENOR Programa Especial do Norte Fluminense

PRODESP Programa de Desenvolvimento Microrregional do Norte do Espírito Santo

PRODEVALE Programa de Desenvolvimento do Vale do Jequitinhonha

PROMORAR Programa de Erradicação da Sub-Habitação

PUB-RIO Plano Urbanístico Básico da Cidade do Rio de Janeiro

PUC/RJ Pontifícia Universidade Católica do Rio de Janeiro

REMI Representação do Ministério do Interior no Rio de Janeiro

RBG Revista Brasileira de Geografia

SAE Secretaria de Assuntos Estratégicos

SAGMACS Sociedade para a Análise Gráfica e Mecanográfica Aplicada aos Complexos Sociais

SALTE (plano) Saúde, Alimentação, Transporte e Energia

SAMI Serviço de Apoio aos Migrantes

SAREM Secretaria de Articulação com os Estados e Municípios

SEMA Secretaria Especial do Meio Ambiente

SEPLAN-PR Secretaria de Planejamento da Presidência da República

SERFHA Serviço Especial de Recuperação de Favelas e de Habitação Insalubre

SERFHAU Serviço Federal de Habitação e Urbanismo 
SERSE Secretaria Especial da Região Sudeste

SIMI Sistema de Informação sobre Migrações Internas

SMU Secretaria Municipal de Urbanismo

SNUC Sistema Nacional de Unidades de Conservação da Natureza

SPLAN Subsecretaria de Planejamento

SPVEA Superintendência do Plano de Valorização da Amazônia

SPVESUD Superintendência do Plano de Valorização da Fronteira Sudoeste do País

SUDAM Superintendência de Desenvolvimento da Amazônia

SUDENE Superintendência de Desenvolvimento do Nordeste

SUDECO Superintendência de Desenvolvimento do Centro-Oeste

SUDESUL Superintendência de Desenvolvimento do Sul

SURSAN Superintendência de Urbanização e Saneamento

TELEBRÁS Telecomunicações Brasileiras S.A.

UERJ Universidade do Estado do Rio de Janeiro

ZEIS Zona Especial de Interesse Social 


\section{SUMÁRIO}

1-APRESENTAÇÃO. 17

2-NOTAS INTRODUTÓRIAS 26

\section{3- PARTE 1-BASES CIENTÍFICAS PARA UMA RACIONALIZAÇÃO, INTEGRAÇÃO E CONSTRUÇÃO DO ESPAÇO URBANO E REGIONAL}

3.1 Capítulo 1 - O ordenamento territorial: a construção de um ideário.

3.1.1 - O ordenamento territorial: o ideário sob novas influências .50

3.2 Capítulo 2 - As influências estrangeiras no ordenamento territorial no Brasil: adaptando racionalidades à realidade do país.

3.3 Capítulo 3 - A institucionalização do planejamento do ordenamento territorial: reflexões comparativas entre França e Brasil.

3.4 Capítulo 4 - A integração vertical e horizontal na perspectiva territorial: os desequilíbrios nas relações entre governos.

3.5 Capítulo 5 - O Ordenamento Territorial Urbano e sua constituição: uma avaliação dos instrumentos urbanísticos

3.6 Capítulo 6 - A questão metropolitana no Ordenamento Territorial: um desafio

3.7 Capítulo - 7- Requisitos para o planejamento governamental: desafios lancados ao desenvolvimento territorial.

4- PARTE 2 - O RIO DE JANEIRO À LUZ DO ORDENAMENTO TERRITORIAL URBANO NO PLANEJAMENTO

4.1 Capítulo 1 - Pontos e contrapontos do ordenamento territorial urbano da metrópole do Rio de Janeiro: subsídios para uma avaliação

4.2 Capítulo 2 - Um breve histórico de estruturação de uma região: dos obstáculos naturais às contradições na estruturação da região

4.3 Capítulo 3 - Uma avaliação da construção política de uma região: da ausência de planejamento ao espaço segmentado e segregado

4.4 Capítulo 4 - Uma região atípica ao ideário do planejamento Integrado: os ideais nacionais e locais em jogo na metrópole.

4.5 Capítulo 5 - As ameaças ao planejamento do desenvolvimento territorial: entre a ação planejada e as intervenções imediatistas.

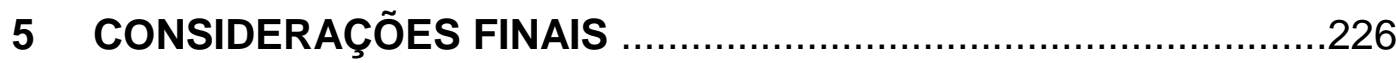

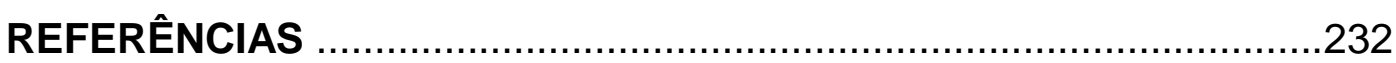

ANEXOS 


\section{APRESENTAÇÃO}

"Um termo francês aménagement não compreende uma noção simples não corresponde nem a planejamento físico ou territorial, nem a planejamento econômico. Desenvolvimento regional e organização do território são noções distintas, pois a organização do território inclui simultaneamente o planejamento setorial e o planejamento espacial. Quando se fala em planning com os anglo-saxões eles pensam essencialmente em desenvolvimento econômico ou planejamento setorial. Nos países latinos, ao contrário, quando se diz planejamento regional se cogita quase sempre, antes de mais nada, do crescimento econômico e só secundariamente em arranjo do espaço ...."

(Jean Labasse e Michel Rochefort in Revista Arquitetura de 1967Organização do Território, disciplina do solo, pág. 23. Palestra proferida no I Ciclo de Conferências sobre Planejamento Urbano, promovido pelo SERFHAU e o Centro de Treinamento e Pesquisa para 0 Desenvolvimento Econômico)

O trabalho que se apresenta é resultante de uma trajetória acadêmica iniciada pelas inquietações com relação ao quadro conflitante das relações sociais estabelecidas na Região Metropolitana do Rio de Janeiro constituída por um núcleo urbano conurbado e seus municípios integrantes. Nascida e criada nessas terras, parti de observações dos mais variados conflitos expressos territorialmente e da percepção do quadro que se apresenta como resultante de um longo período histórico de estruturação desse espaço. A percepção da realidade metropolitana no país foi tratada pelo governo de forma tardia quando vários problemas urbanos instalados apontavam para reformulação do planejamento do desenvolvimento territorial.

Em vista das dificuldades de compreender o ordenamento territorial no processo de planejamento do governo numa realidade como a da metrópole do Rio de Janeiro, a proposta do trabalho é lançar um pensar e um modo de atuar novos numa realidade de estruturação e consolidação extra município, de provável concepção regional, inter-regional e até nacional com base na relação direta dos habitantes com os recursos naturais e dos habitantes com a acessibilidade à infraestrutura em geral. A investigação parte dos obstáculos ou [Digite texto] 
limitações impostos na implementação das políticas de ordenamento territorial à luz da estrutura de planejamento no país ao longo dos anos e a avaliação de seus resultados.

A opção pela extensão do período em análise: antes e após a Segunda Guerra Mundial até aos dias atuais, durante períodos democráticos e autoritários do país teve por objetivo abarcar uma miríade de racionalidades predominantes e determinantes das políticas intervencionistas desconexas de um ideário maior de ordenamento territorial a que foi submetida à região metropolitana em questão. A escolha por um período mais extenso de análise permitiu uma percepção de descontinuidade das políticas urbanas por questões políticas num contexto de continuidade das políticas intervencionistas desconexas de um sistema de planejamento integrado, permitindo com isso um acúmulo de situações ilegais e informais que contribuem para o agravamento das condições de vida de seus habitantes.

Partindo de determinadas nuanças da estruturação do espaço em questão, a favela simboliza um dos mais perfeitos exemplos de espaço contido no tecido urbano, porém nunca integrante e sempre distante das políticas urbanas gerais adotadas. Instituições governamentais e religiosas intervinham nas favelas reforçando racionalidades até antagônicas reforçando a ausência de uma unidade de política urbana e regional. A favela sempre assumiu um importante papel de elemento estruturante e estruturador desse processo. A favela se insere perfeitamente no processo de descontinuidade das políticas governamentais e ao mesmo tempo de continuidade das políticas intervencionistas sem o aporte de um sistema de planejamento integrado. Considera-se que favela tornou-se um grande palco das políticas sociais do governo principalmente a partir de vultosas quantias provenientes das instituições financeiras mundiais e, portanto manter esses espaços carentes de infraestrutura, ilegais do ponto de vista fundiário, não reconhecidos como espaços para uma política habitacional do governo, composto por problemas sociais e distantes do ordenamento territorial justifica a continuidade das políticas clientelistas ao longo do tempo. 
Tornou-se muito importante criar verdadeiros parâmetros com relação ao ordenamento territorial em realidades político-institucionais diferentes como a do Rio de Janeiro e a de Paris, que permitissem subsidiar as análises e críticas desenvolvidas ao longo do trabalho. Ao analisar a estrutura de poder do governo sobre o território numa realidade expressa do federalismo e do desenvolvimento institucional à luz do aménagement du territoire entre Paris e Rio de Janeiro, percebe-se o quanto a concepção do ordenamento territorial e sua prática de fato devem avançar no nosso país, principalmente a partir de uma percepção política da própria sociedade e consequentemente em termos políticos, jurídicos e administrativos. Vale acrescentar a urgente revisão das relações estabelecidas entre governos de modo a subsidiar a proposta de ordenamento territorial em contraposição ao chamado federalismo predatório estabelecido no país em que uma competição muito acirrada entre governos contraria o princípio de cooperação e equilíbrio e leva as perdas expressivas de recursos para atrair investimentos a partir de incentivos e isenções fiscais que poderiam perfeitamente ser revertidas nas demandas de transportes, moradias, hospitais, escolas, saneamento dos habitantes por melhores condições de vida na metrópole.

O trabalho ressalta que a concepção de ordenamento territorial no Brasil surgiu atrelada ao processo de desenvolvimento econômico e social sobre o poder dos organismos e instituições internacionais. O ideário que se consolidou no país se impõe de modo autoritário "de cima pra baixo" principalmente com a tomada do governo pelos militares no contexto de grandes e acirradas rivalidades ideológicas no mundo. As políticas de desenvolvimento regional sustentavam-se pelo discurso nacionalista cujas ações e intervenções tinham por base todo o território nacional. A racionalidade predominante era de ocupação do território a partir de uma política de planejamento físicodemográfico capaz de propiciar a integração das áreas já ocupadas aos vazios visando um desenvolvimento orgânico e de forma a obter melhor rendimento aos investimentos públicos e privados.

A ideia principal que norteava as políticas era que as disparidades regionais estariam relacionadas à má distribuição da população e a necessária estratégia de localização de novos investimentos. Portanto, os problemas que 
se avolumavam nas metrópoles seriam solucionados a partir do controle dos fluxos migratórios. Surge a necessidade de introduzir uma política de uso da terra urbana e rural que visasse desestimular a especulação imobiliária e a consequente ordenasse o território. Assim, passando por uma reformulação da estrutura administrativa do governo federal, foi atribuído ao Ministério do Interior competência sobre assuntos relativos ao desenvolvimento regional, controle das migrações internas, ocupação do território, saneamento básico e a proteção contra as secas, irrigação, assistência aos municípios e programa nacional de habitação numa experiência única de ordenamento territorial. Busca-se o importante papel da SERSE e da FUNDREM nesse processo de ordenamento territorial da Metrópole do Rio de Janeiro.

Dos acervos consultados, alguns artigos da Revista Arquitetura, em especial dos anos de 1963 e 1967, apontavam a tamanha importância do planejamento integrado no país a partir do conhecimento da realidade social, econômica, ambiental e cultural do espaço que atuamos ou intencionamos atuar. $O$ trabalho em si busca a análise do ordenamento territorial entre escalas político-administrativas sobre um território de notável base regional. Considerando as mudanças das relações entre governos nos últimos anos, percebe-se que após a última Constituição Federal de 1988 medidas corroboram o centralismo de recursos e competências da União e um intenso processo de municipalização das políticas de ordenamento territorial, sem os necessários avanços das condições financeiras, jurídicas e administrativas para o pleno desenvolvimento das funções dos governos locais nesse processo.

A estruturação do espaço em questão teria desde os primórdios uma diretriz racional inserida numa lógica predominante de cada momento histórico e político e, portanto, o atual quadro conflitante das relações seria resultante das diretrizes racionais que de alguma forma buscaram ordenar esse território. Coube buscar o aporte teórico no ordenamento territorial ou Aménagement du Territoire de modo a criar um contraponto às racionalidades ao longo do tempo e que de certa forma contribuem no aprofundamento da análise da estruturação desse espaço. A avaliação do ordenamento territorial no planejamento governamental, no caso do Rio de Janeiro, teve por base as 
condições físicas, constitutivas, administrativas, jurídicas e políticas, além dos planos, programas e instrumentos urbanísticos que se tornaram frágeis diante das grandes mudanças das relações políticas entre países, governos e sociedades.

Em nosso estudo de caso, a concepção do planejamento urbano esteve sempre restrita ao local tratando dos aspectos urbanísticos da cidade e muitos estudiosos, pesquisadores e planejadores atentavam para a necessidade da multiplicidade de visões de diferentes profissionais e da interdisciplinaridade, principalmente pela visão qualitativa na importante tarefa de ordenar 0 território. Muito mais que apenas planejar o desenvolvimento territorial integrado, ordenar o território impõe uma preocupação em oferecer bem-estar aos habitantes por um longo tempo e deve-se muito mais alcançar resultados sociais numa desafiante tarefa de reformular o que se realizou até os dias atuais. A principal intenção é despertar para uma nova forma de pensar e agir.

Pretende-se que a presente tese possa contribuir em termos teóricos e reflexivos para a reformulação de uma prática de planejamento governamental, que tenha por base, o ordenamento territorial. Metrópoles e regiões metropolitanas devem se inserir no contexto do ordenamento territorial que é uma base efetiva para a promoção de mudanças, rumo a um amplo desenvolvimento e bem-estar de seus habitantes.

O período atual corresponde a um momento histórico de transformações, novas perspectivas e percepções. Nele, torna-se necessário reconhecer a importância do planejamento do desenvolvimento territorial de modo integrado entre as instâncias do governo e direcionado às regiões metropolitanas, a partir do reconhecimento da necessidade de se criar um novo projeto, em que políticas e ações de desenvolvimento territorial busquem aperfeiçoamento, transformação e mudança no sistema de planejamento no país.

O fio condutor que induzirá o presente trabalho de avaliação e investigação é a hipótese de trabalho enunciada a seguir:

O ordenamento territorial urbano deve ser uma ação científica, técnica e política necessária para conjugar todos os interesses em jogo na ocupação e apropriação do espaço metropolitano, porém, não se mostra suficiente para 
garantir a funcionalidade dos territórios e o bem-estar dos habitantes das regiões metropolitanas. No caso brasileiro, a perspectiva regional dos planos nacionais tem se deparado com os limites nas relações intergovernamentais previstas na Constituição Federal, com o centralismo do governo federal e com os entraves institucionais para legitimar a realidade metropolitana do país. Neste século, diante do agravamento da crise econômica no mundo e interna do país, a perspectiva estratégica nacional e subnacional foi abandonada pelo governo dando lugar aos planos de estabilização monetária e financeira e novas influências políticas e tecnológicas que surgiam, apontando para a necessidade de um outro ordenamento territorial urbano, mais abrangente que o até então concebido.

Para a discussão desta hipótese, esta tese está dividida em duas partes.

A Parte 1, intitulada "Bases científicas para uma racionalização, integração e construção do espaço urbano e regional" consiste em análises do ordenamento territorial tendo por base as concepções originais de Lebret, Labasse e Boudeville, e concepções tidas como mais modernas de Lefebvre e Subra. Trata-se de apreender os princípios, mecanismos e políticas capazes de promover o ordenamento rumo a outro planejamento do desenvolvimento territorial com maior justiça social. Pretende-se verificar as possíveis influências externas, em especial norte-americanas e francesas, no ordenamento territorial das regiões metropolitanas brasileiras e estabelecer analogias entre a institucionalização do ordenamento territorial na França e no Brasil e a estrutura de planejamento do desenvolvimento integrado do território entre diferentes realidades constitutivas de sistemas de governos.

A Parte 2, intitulada "O Rio de Janeiro à luz do ordenamento territorial urbano no planejamento governamental" parte do reconhecimento de que a Região Metropolitana do Rio de Janeiro inseriu-se no processo de ordenamento territorial urbano de modo tardio e sem os avanços institucionais e estruturais de planejamento mais efetivos, resultando nos mais sérios impactos sócio-econômicos gerados por este processo. São elaboradas análises sobre a estruturação desse espaço segundo:

- os aspectos físicos;

- os recursos naturais;

- a constituição político-administrativa de diferentes épocas;

[Digite texto] 
- a dinâmica urbana;

- os arranjos político-institucionais;

- as funções urbanas, - o papel dos órgãos governamentais;

- os instrumentos disciplinadores do uso do solo;

- planos e programas;

- as políticas públicas;

- a legislação urbanística.

Tais elementos são, todos eles, pertinentes à prática do planejamento do desenvolvimento integrado do território, no contexto político e geopolítico em que se insere o ordenamento territorial urbano no país. A fim de estabelecer uma conexão com a Parte 1, realizou-se esforço por elaborar uma relação entre o planejamento do desenvolvimento integrado do território e a concepção do ordenamento territorial, pretendendo-se construir reflexões quanto aos fatores presentes ou ausentes no ordenamento territorial urbano da metrópole carioca.

Como parte inspiradora das reflexões que se seguem sobre 0 ordenamento territorial no processo de planejamento governamental, segundo o ex: ministro do planejamento dos governos Médici e Geisel, Sr. Reis Velloso ${ }^{1}$, em entrevista (Anexo A), para que se criem estratégias de planejamento territorial, é necessário antes de tudo que se tenha uma determinada concepção de país, um Projeto de Brasil. As estratégias devem se voltar à economia do conhecimento aplicada em todos os setores econômicos e a todos os segmentos da sociedade, aproveitando as grandes oportunidades de

\footnotetext{
1 - O economista João Paulo dos Reis Velloso organizou o EPEA- Escritório de Pesquisa Econômica e Social em 1964, atual IPEA- Instituto de Planejamento Econômico e Social. Como Ministro do Planejamento no governo de Médici, realizou-se o Censo de 1970, a cargo do IBGE- Instituto Brasileiro de Geografia e Estatística, vinculado ao Ministério do Planejamento; criou o Fundo de Reorganização e Modernização Industrial, coordenou a elaboração do Programa de Metas e Bases para a Ação do Governo e os programas nacionais de desenvolvimento, organizou o I PND para o período de 1972 a 1974 e coordenou o Plano Básico de Desenvolvimento Científico e Tecnológico e tornou-se professor da EPGE-Escola de Pós-Graduação em Economia da Fundação Getúlio Vargas em 1973. No governo de Geisel, o então Ministério do Planejamento transformado em Secretaria de Planejamento da Presidência da República a fim de aproximar o órgão do presidente da República, a quem daria assistência na coordenação dos programas de planejamento, elaborou o II PND em 1974. Em 1980, tornou-se presidente do IBMEC- Instituto Brasileiro de Mercado de Capitais, ligado à Bolsa de Valores do Rio de Janeiro. Foi membro do Conselho de Administração do BNDES entre 1991 e 1997, em 1992 passou a coordenar o Fórum Nacional, promovido pelo INAE- Instituto Nacional de Altos Estudos, espaço de encontro de economistas, cientistas sociais e políticos, lideranças sindicais, empresariais e políticas, para discussão de temas sociais e econômicos da atualidade.
}

[Digite texto] 
que dispõe o Brasil; além disso, garantindo a qualidade dos técnicos de planejamento e estudos desenvolvidos pelos órgãos, autarquias e empresas públicas de planejamento. $O$ país precisa ser pensado a médio e longo prazo para que de fato haja planejamento. O planejamento regional deve-se voltar para as oportunidades de cada região. Existe, portanto, um grande desafio ao governo que é resgatar o ideário do desenvolvimento metropolitano no país, aprofundando os princípios de cooperação e confiança entre agentes públicos e privados e a sociedade, num ambiente em que se entrecruzam os mais variados conflitos e interesses.

Algumas questões colocadas pelo Sr. Reis Velloso em entrevista foram de grande valia na condução deste trabalho. $O$ ex-ministro do planejamento questiona sobre que direção o país seguiria e sobre como queríamos que o Brasil fosse entregue à próxima geração. O Sr. Reis Velloso invoca a importância de se resgatar a concepção do planejamento que impulsiona a iniciativa privada. E citando o escritor espanhol Salvador de Madariaga, sintetiza: o planejamento é para ordenar as forças vivas da sociedade.

Deve-se perguntar sempre, a quem interessa uma ação e intervenção planejada a médio e longo prazo? Estão todos os agentes públicos e privados, e instituições preparados para este processo? A princípio, alguns fatores são de extrema importância e devem nortear o planejamento do desenvolvimento territorial integrado como: os meios de articulação entre os agentes públicos e privados e a sociedade, a capacidade de governança, os avanços institucionais e um sistema dinâmico de dados e informações sobre uma determinada realidade, instituindo um aprendizado contínuo de todos os agentes, técnicos, estudiosos e profissionais envolvidos.

Assim, a ação de planejamento proposta pretende defender a sua importância no ordenamento territorial urbano levando às reflexões necessárias aos avanços institucionais, visando especialmente à articulação de políticas públicas e interesses nacionais, regionais e locais no desenvolvimento. Há uma proposta de modelo de pensar e uma nova atitude a serem construídas, para que ações coordenadas de controle público e privado tornem-se instrumentos capazes de acompanhar a dinâmica das relações sociais sobre o território; e de dotar o governo de percepções, mecanismos e mudanças no controle do processo do ordenamento territorial urbano, criando ou fortalecendo as 
instituições. E, para que assim se alcance, é necessário criar uma nova percepção sobre o planejamento na sociedade e da importância do desenvolvimento integrado do território baseada numa capacitação dos profissionais dos órgãos de planejamento a partir de verdadeiros subsídios às ações articuladas ou integradas que visem à funcionalidade do território e qualidade de vida de seus habitantes. 


\section{NOTAS INTRODUTÓRIAS}

O objetivo geral deste trabalho é o de avaliar a consolidação do espaço urbano do Rio de Janeiro à luz do ideário do ordenamento territorial urbano, considerando o contexto político e geopolítico, a estrutura de planejamento, normas e leis urbanísticas, o desempenho das instituições nas intervenções promovidas em seu território.

Figura 1 - O Rio de Janeiro, sua Região Metropolitana e o Estado do Rio de Janeiro

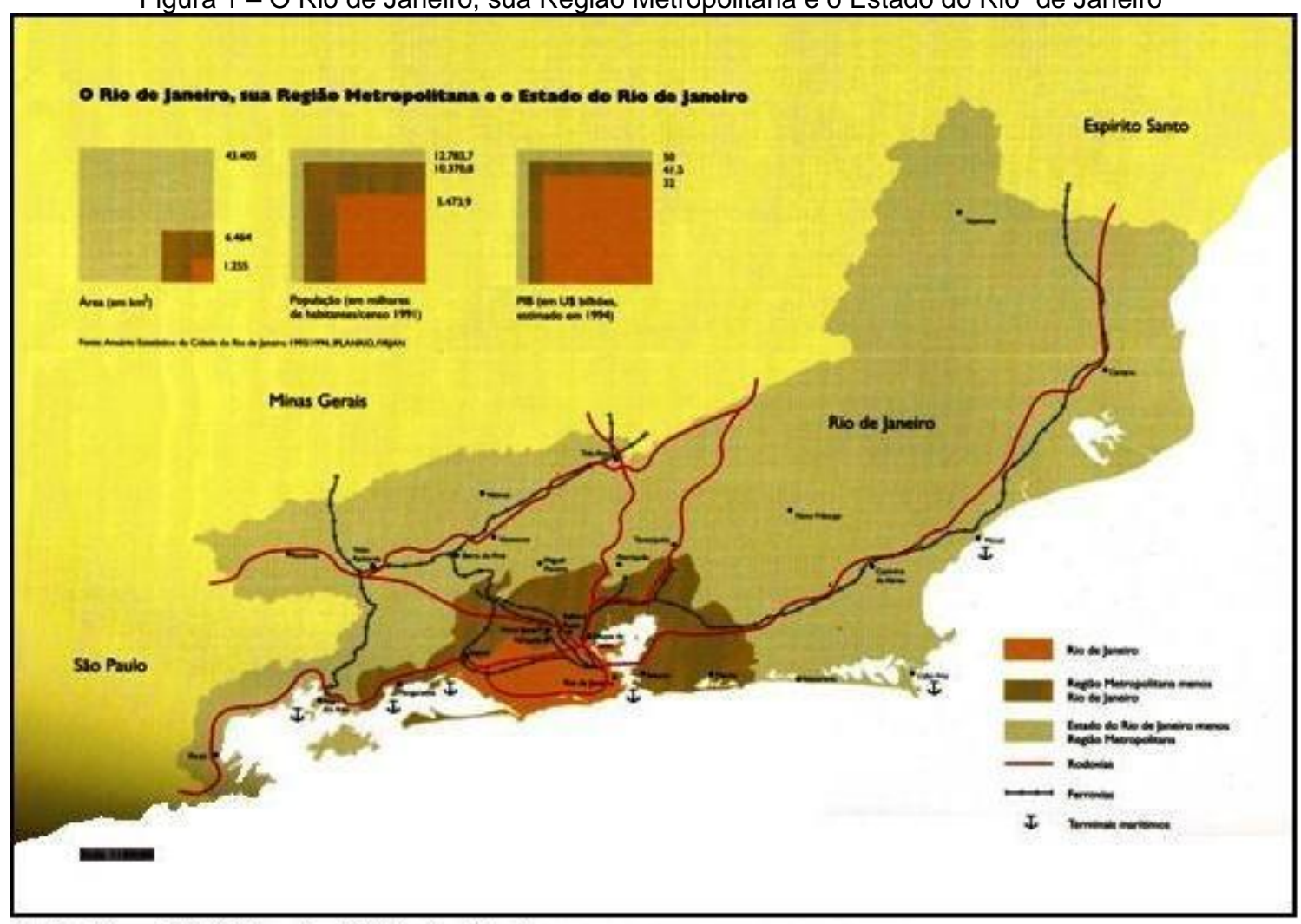

Fonte: Plano Estratégico da Cidade do Rio de Janeiro - Rio Sempre Rio, 1996

A trajetória acadêmica e profissional da autora justifica o tamanho desafio do trabalho que se apresenta e baseia-se em experiências adquiridas ao longo do período de graduação em Geografia na UERJ, especificamente quanto ao estágio no IBAM- Instituto Brasileiro de Administração Municipal no Centro de Estudos e Pesquisas Urbanas com a participação em planos-diretores de municípios brasileiros assim como no Projeto Megacidades. A formação multidisciplinar das equipes técnicas dos planos-diretores e as concepções sobre o espaço segundo diretrizes e legislações imperativas que lançavam um ambiente de diversos interesses atuantes com influências diretas da sociedade 
organizada, do setor público e privado no ordenamento territorial e os desafios lançados às metrópoles mundiais quanto à qualidade de vida de seus habitantes contribuíram de fato para o despertar da autora por novas reflexões sobre a metrópole do Rio de Janeiro. Ao de término do curso de graduação elaborou-se uma monografia intitulada "Paquetá: a ilha dos (des)amores" orientada pelo professor Gilmar Mascarenhas cujo enfoque principal é a análise da decadência social, econômica e ambiental da llha de Paquetá no contexto urbano da cidade do Rio de Janeiro. Iniciou-se assim os primeiros passos de uma reflexão sobre as nuanças da cidade do Rio de Janeiro.

Buscou-se em 2000, no curso de especialização em Organização Espacial do Rio de Janeiro na UFF, maior aprofundamento sobre a cidade do Rio de Janeiro. A monografia elaborada e intitulada "Uma análise sobre a política urbana desenvolvida pelo Plano Estratégico do Rio de Janeiro durante o governo César Maia (1993 a 1995)" tem por objetivo analisar os projetos urbanos desenvolvidos para a cidade neste período para a cidade na perspectiva do plano que proporciona uma visão multifacetada das políticas públicas adotadas pelo poder local refletida nas grandes reestruturações e adaptações do espaço urbano.

Em 2002, a dissertação de mestrado da autora ${ }^{2}$ permitiu constatar que a estrutura de planejamento tinha sido relativamente preterida pelo governo local, que passou a priorizar os chamados planos estratégicos de cidade a partir dos anos de 1990. Um dos principais instrumentos de planejamento, como o plano diretor, necessitava de revisões e atualizações e não direcionava as ações e intervenções do governo sobre o território. Diante de uma queda expressiva da participação da cidade no PIB estadual e nacional e o considerável

\footnotetext{
2 Uma leitura geográfica dos Planos Estratégicos da Cidade do Rio de Janeiro" dissertação apresentada ao término do curso de Pós-Graduação Stricto-Sensu em Ordenamento Territorial e Ambiental da Universidade Federal Fluminense em 2002 sob a orientação do Prof. Hélio de Araújo Evangelista. 0 enfoque da dissertação foi a reafirmação e adaptação da cidade do Rio de Janeiro às mudanças que ocorrem no mundo da globalização em que é lançada a disputa entre cidades para se tornarem espaços atraentes aos grandes empreendimentos susceptíveis aos grandes negócios, às grandes transações econômicas e aos grandes eventos culturais. Os Planos Estratégicos de Cidades foram elaborados pelo governo local nos anos 90 sob o ideário da gestão empresarial regidos pelos princípios mercadológicos. A experiência de Barcelona em sediar as Olimpíadas em 1992 inspirou a administração local da cidade do Rio de Janeiro em adequar o espaço urbano às grandes mudanças no controle dos fluxos de capitais, bens e serviços e assim buscar-se-ia uma alternativa para reverter o quadro de deterioração dos equipamentos urbanísticos e da crise sócio-econômica na cidade.
}

[Digite texto] 
agravamento das condições sociais e econômicas expressas no acirramento dos conflitos territoriais, a impressão que o trabalho deixou foi que o futuro da cidade estaria entregue às mãos dos grandes investidores e empreendedores, apenas. As ações e intervenções do governo consistiam nos projetos urbanos localizados e o principal papel do governo seria regulamentá-los ou promovêlos a partir de parcerias público-privadas entre outras. As definições quanto ao uso e ocupação do solo dispostas no plano diretor eram irrelevantes nas tomadas de decisões políticas diante das inúmeras possibilidades de burlar a lei sem avaliar seus impactos, dando prioridade ao ideário empreendedorista da cidade. Onde estaria o planejamento? Como entender a dinâmica das transformações urbanas do Rio de Janeiro na perspectiva integrada das políticas local, regional e nacional? Caberia maior aprofundamento do tema numa perspectiva de avaliar as intervenções no plano físico e suas implicações nas relações sociais. O estudo proposto abarcaria uma visão territorial integrada que desse os necessários subsídios para uma reflexão quanto às condições político-administrativa da cidade do Rio de Janeiro e seus resultados à luz do ordenamento territorial urbano.

Considerou-se o quanto seria relevante realizar esse trabalho na tentativa de contribuir para a construção do conhecimento que envolva uma avaliação mais aprofundada das relações que se estabelecem e se expressam territorialmente na metrópole do Rio de Janeiro, considerando algumas peculiaridades que despertaram interesses diversos.

A escolha da metrópole do Rio de Janeiro justifica-se pelas instigantes peculiaridades que envolvem o seu ordenamento territorial urbano. A atual metrópole carioca em questão assumiu a condição de Distrito Federal em 1889 com a Proclamação da República a 1960 quando foi transferida para Brasília essa titularidade e nela se instaurou o Estado da Guanabara que assim permaneceu até 1975 , quando foi alvo de uma manobra estratégica do governo federal, a fusão entre os Estados, e tornou-se município e capital do Estado do Rio de Janeiro. Essas diferentes condições político-administrativas assumidas pela metrópole foram fundamentais no processo de consolidação de seu território desarticulado do ponto de vista estrutural e político de sua respectiva região metropolitana. As condições político-administrativas assumidas pela metrópole inserem-se no contexto de racionalização do ordenamento territorial 
e das políticas regionais formuladas pelo governo federal. Assim, avaliar a estruturação física e social da metrópole carioca à luz do ordenamento territorial urbano envolve considerar as condições político-administrativas e seu peso na formulação de leis e normas urbanísticas que de fato foram determinantes nesse processo.

A fim de avaliar a consolidação da metrópole carioca sob a ótica do ordenamento territorial urbano, toma-se por ponto de partida o levantamento dos planos, leis e normas urbanísticas predominantes em cada momento político-administrativo da cidade, levando em conta sua inserção no contexto político e geopolítico do período. Acredita-se merece destaque a tentativa de detectar o ideário predominante de cada momento associado à estrutura de planejamento, às intervenções propostas e/ou realizadas e seus resultados.

Diante da atual configuração territorial da metrópole carioca como núcleo hipertrofiado, concentrador da maioria da renda e dos recursos urbanísticos disponíveis, cercado por estratos urbanos periféricos cada vez mais carentes de serviços e de infraestrutura à medida que se afastam do núcleo, o primeiro pressuposto seria que em todas as condições político-administrativas assumidas pela cidade no contexto político e geopolítico do país, a formulação de planos e programas e de leis e normas urbanísticas numa estrutura ineficiente de planejamento iam ao encontro do ideário do ordenamento territorial urbano vigente.

Em outras palavras, a atual configuração da metrópole carioca resultaria do acúmulo de condições físicas, políticas e históricas que contribuíram para a estruturação de uma metrópole conurbada; e desconexa de sua região metropolitana e muito complexa na implementação das políticas de ordenamento territorial urbanas.

No decorrer da pesquisa alguns contratempos se fizeram presentes, como a escassez de material e a localização do acervo da Secretaria Especial da Região Sudeste (SERSE), e da Representação do Ministério do Interior no Rio de Janeiro (REMI/MINTER). Tendo em vista o relatado por Abreu (2001:21) sobre o acervo da SUDECO $^{3}$ (Superintendência de Desenvolvimento do

\footnotetext{
${ }^{3}$ A Superintendência de Desenvolvimento do Centro Oeste ou SUDECO é uma autarquia federal brasileira criada por meio da lei No 5.365 de 10 de dezembro de 1967 com o objetivo de promover o [Digite texto]
} 
Centro-Oeste) que foi esfacelado posteriormente à extinção do órgão em 1990, no governo Collor; conclui-se que o mesmo tratamento tenha sido dado à documentação em pauta no contexto de redução de órgãos do governo à época.

Depois de um longo período procurando e coletando material bibliográfico e documental e contactando órgãos, bibliotecas e pessoas que estiveram envolvidas de alguma forma com a SERSE, como os Ministérios do Planejamento, Orçamento e Gestão, das Relações Exteriores, da Integração e do próprio Congresso Nacional; obtivemos cópias dos relatórios de auditoria referente à tomada de contas da REMI nos anos de 1970 e ratificadas pelo ministro Maurício Rangel Reis. Localizamos também relatórios da SERSE, que substituiu a REMI em 1979, referentes aos anos de 1980 e ratificados pelo ministro Mário David Andreazza, em correspondência ao previsto no art. 82 do Decreto-Lei 200/1967. O acervo de consulta restringiu-se a poucos livros disponíveis na Biblioteca Nacional e aos Diários Oficiais da União (Anexo D). Acreditamos que esta constatação seja um aspecto importante, resultado desta pesquisa.

Compreender as limitações impostas pelas dificuldades apresentadas acima permitiu que nos aprofundássemos em nossas reflexões acerca da defasagem cultural, documental e até mesmo da percepção em trocar experiências, o que de certa forma nos faz concluir o quanto ainda devemos avançar. Para tanto, embora não pudéssemos contar com todo o acervo da secretaria, consideramos fundamental avaliar aspectos das ações programadas no ordenamento territorial urbano da metrópole carioca nesse período, de modo a possibilitar uma idéia da intenção do governo em atuar de modo integrado com outros níveis de governo.

De modo contextualizado, cada momento político e geopolítico abordado refletia-se na definição dos atributos e na capacidade tributária de cada ente federativo, nos planos e programas do governo e nas leis e normas urbanísticas que foram de fundamental importância na compreensão do

desenvolvimento econômico da região Centro-Oeste. Foi extinta em 1990 durante o governo Collor e somente em 2008 no governo Lula foi proposta a recriação da autarquia, mas a sua recriação de fato só foi regulamentada no governo Dilma que a recriou em 2011 vinculada ao Ministério da Integração Nacional".

[Digite texto] 
processo de estruturação da metrópole do Rio de Janeiro. A estruturação da metrópole carioca é resultado marcante do modelo econômico implantado no país desde os anos de 1930, quando já assumia a importante condição políticoadministrativa de Distrito Federal, com forte presença intervencionista do governo federal e dos interesses elitistas nas políticas de ordenamento territorial. Isso, até 1960, quando assumiu a condição de Estado da Guanabara e após 1975 quando assumiu a condição de município do Estado do Rio de Janeiro.

Nesse sentido, no primeiro capítulo, "O ordenamento territorial: a construção de um ideário" procuramos contextualizar o ideário do ordenamento territorial como estratégia de consolidação e reprodução das relações capitalistas, a partir da compreensão dessa base de sustentação teórica que tem na racionalidade impressa nas ações e intervenções do governo sobre 0 território uma forma de ampliar o controle político, econômico e social legitimado pelos instrumentos jurídicos e administrativos.

Encontramos em Lebret (1952,1956,1958 e 1961) subsídios importantes para compreender uma proposta de ordenamento territorial mais humanista em contraposição à racionalidade de reprodução capitalista que pode levar à degradação das condições mínimas de vida, e ao aumento de produção e exploração da maioria da população. Trata-se de compreender que a reprodução das relações capitalistas ocorre de forma descontínua e desigual e se expressam espacialmente nas disparidades entre regiões e por vezes em degradantes condições de vida. O mesmo governo que assumiria os mecanismos de reprodução das relações capitalistas seria responsável pelo ordenamento territorial que deveria visar sempre à valorização humana.

Segundo Labasse (1960), a racionalidade que se afirmou nos anos $60 \mathrm{e}$ 70, para melhor dispor equipamentos sobre o território, geraria desigualdades que por sua vez desencadeariam a elaboração de políticas de ordenamento territorial expressas nas leis de controle do uso do solo. Por outro lado, as leis de controle do uso do solo se deparariam com os interesses privados de se extrair lucro na apropriação do solo urbano.

Para Boudeville (1972), o ordenamento territorial se faz necessário diante da realidade das aglomerações urbanas. A teoria dos pólos de crescimento, muito mais apropriada nesses casos, reduziria as disparidades 
regionais, numa concepção geométrica do espaço que imporia uma redistribuição do equipamento sobre o território a fim de equilibrar os fluxos e migrações intra-regional e inter-regional. Nos casos dos países considerados subdesenvolvidos, os maiores desafios em ordenar o território estariam na defasagem de dados e conhecimentos de suas próprias realidades.

Assim, o ideário do ordenamento territorial que se propaga é o de equilibrar e integrar regiões e controlar a pressão sobre o solo urbano das grandes metrópoles.

No subcapítulo, "O ordenamento territorial: o ideário sob novas influências", procuramos avançar na concepção do ordenamento territorial direcionado para os novos arranjos territoriais com base nos avanços científicotecnológicos no contexto da máxima internacionalização econômica e dos novos atores e interesses em questão. Novas variáveis foram acrescidas à concepção original. Encontramos em Lefebvre (2003), os argumentos necessários para criar um contraponto à concepção original e a avançar numa outra perspectiva, de modo a permitir a compreensão das transformações ocorridas nos últimos tempos e dos numerosos atores e seus interesses que se coadunam de forma complexa no ordenamento territorial.

E em Subra (2007), encontramos que o ordenamento territorial é uma questão política e geopolítica numa perspectiva desafiadora de conciliar numerosos conflitos pelo número maior de grupos sociais participantes nas decisões políticas, de projetos concorrentes sobre um determinado território, principalmente no contexto da redemocratização dos meios participativos e do processo de descentralização do poder ou poderes sobre o território.

Assim, no capítulo dois, "As influências estrangeiras no ordenamento territorial no Brasil: adaptando racionalidades à realidade do país", procuramos contextualizar e justificar as influências externas no ordenamento territorial no país. A aproximação das relações entre os Estados Unidos e o Brasil no período pós Segunda Guerra Mundial permitiu que o governo central assumisse o principal papel condutor do desenvolvimento do país com base no discurso de redução das disparidades entre regiões e de integração do território nacional. A introdução da prática do planejamento nas estruturas do governo significou o meio mais seguro para investimentos produtivos e grandes reformas estruturais no país. 
Ao passo da formação das grandes metrópoles, influências francesas de ordenamento territorial ou aménagement du territoire foram introduzidas, como foi o caso da teoria dos pólos de crescimento, e isso levou às novas regionalizações do território nacional, em contraponto ás tradicionais macrorregiões do Brasil. Outras influências propunham novas percepções para fins de planejamento, num contexto mais amplo de desenvolvimento.

No capítulo três, "A institucionalização do ordenamento territorial no planejamento: reflexões comparativas entre França e Brasil", destaca-se a institucionalização do ordenamento territorial francês e brasileiro com base nos distintos processos de democratização e descentralização das políticas e nos avanços institucionais, sociais e de infraestrutura de cada realidade. Os maiores avanços do ordenamento territorial estariam relacionados ao nível de descentralização e dos avanços institucionais. No caso do Brasil, as políticas de centralização de recursos e poder pelo governo central dificultariam o ordenamento territorial compartilhado entre os diversos níveis de governo. Houve, inclusive, experiências não tão bem sucedidas de se implantar um sistema de planejamento integrado, contando com a forte presença de órgãos do governo central nas políticas regionais e locais de ordenamento territorial. Recentemente, o grande desafio do ordenamento territorial é retomado pelo reconhecimento de sua importância para o desenvolvimento do país, apesar do elevado déficit institucional e administrativo. Urgentes mudanças se fazem necessárias no contexto de novas percepções e concepções do desenvolvimento territorial.

No capítulo quatro, "A integração vertical e horizontal na perspectiva territorial: os desequilíbrios nas relações entre governos" relata a importância das relações entre governos no ordenamento territorial. A autonomia delegada aos Estados e municípios passa muito mais pelo processo de desoneração de encargos e obrigações do governo central. Municípios assumiram encargos sociais e de desenvolvimento do país, sem apresentarem as necessárias condições tributárias, administrativas, financeiras e políticas. As relações verticais e horizontais importantes na perspectiva regional do desenvolvimento encontram-se desequilibradas principalmente quanto à restrita capacidade tributária de Estados e municípios, situação ora agravada pelas recentes medidas coercitivas de controle do orçamento público. No caso das regiões 
metropolitanas e aglomerações urbanas são necessários novos acordos entre as unidades territoriais, novos arranjos administrativos e reformas na capacidade tributária dos níveis de governo e dos repasses entre governos de modo a garantir os bens e serviços básicos à população. $O$ associativismo territorial e o consorciamento são considerados como alternativas, mas que necessitam de avanços institucionais e até normativos para que não firam os princípios constitucionais das isenções fiscais e não aniquilem a autonomia municipal. Na ausência de um sistema de planejamento, os acordos entre governos, empresas públicas, agências regionais de desenvolvimento e organização não governamentais põe em risco a própria capacidade de governança tão importante no ordenamento territorial.

No capítulo cinco, "O ordenamento territorial urbano e sua constituição: uma avaliação dos instrumentos urbanísticos" atenta para o importante papel político que o plano diretor assumiu na última Constituição Federal, que se sobrepõe aos demais instrumentos urbanísticos de modo mais generalizante afastando, de certa forma, o propósito de ordenar realidades locais. O Estatuto da Cidade reforça os instrumentos urbanísticos, mas por vezes distantes de uma visão mais rigorosa das necessidades locais com base nas diferenças e características dos diferentes grupos sociais. Os instrumentos urbanísticos encontram-se um tanto desconexos, sem se complementarem na própria perspectiva do ordenamento territorial urbano e necessitam de maiores avanços jurídicos, institucionais e administrativos no próprio processo contínuo de planejamento do desenvolvimento territorial, principalmente nas grandes metrópoles.

O capítulo seis, "A questão metropolitana no ordenamento territorial: um desafio" expõe o grande desafio de ordenar grandes metrópoles ou evitar que as mesmas acabem por se tornar espaços muito onerosos às políticas de ordenamento territorial. Da forma rápida e desordenada como as metrópoles latinas se formaram os desafios se tornam ainda maiores. Diante da realidade das grandes metrópoles, reformas tributárias, jurídicas e administrativas se fazem urgentes, além de uma nova percepção e concepção do planejamento no ordenamento territorial urbano.

O capítulo sete, "Requisitos para o planejamento governamental: desafios lançados ao desenvolvimento territorial" trata da crise do [Digite texto] 
planejamento, que se abateu no país juntamente com a crise do papel político do governo. Outros fatores contribuem para a crise do planejamento, como a fragilidade dos instrumentos institucionais, a ausência de conscientização e apoio político da sociedade à importância do planejamento no desenvolvimento do país. O planejamento deve abranger todos os níveis de governo de forma sistemática. O processo de redemocratização e descentralização impôs novas percepções e concepções ao planejamento do desenvolvimento territorial com base nos novos arranjos territoriais, e de um novo cenário de múltiplos interesses em jogo. O equilíbrio fiscal passou a ser prioridade do governo com grandes perdas na perspectiva do desenvolvimento regional. Os planos plurianuais de base regional se deparam com um sistema municipalizado de políticas públicas dificultando os avanços nas políticas regionais no país.

No capítulo 1 da Parte 2, "Pontos e Contrapontos do ordenamento territorial urbano da metrópole do Rio de Janeiro: subsídios para uma avaliação" situam-se as dificuldades em se estabelecer políticas de ordenamento territorial urbano na metrópole carioca. A posição foi na realidade o fator de maior importância para a consolidação da metrópole. As dificuldades de se estabelecer uma estrutura de planejamento do desenvolvimento territorial permitiram que outros fatores fossem determinantes na estruturação do espaço bastante segmentado quanto à oferta de bens e serviços, segregado socialmente e totalmente desarticulado de sua região de influência. A complexa situação jurídica de propriedade sempre dificultou o processo de regularização fundiária tão importante às políticas de ordenamento territorial. Leis, normas, planos e programas não atendem à realidade dinâmica da estruturação da metrópole. A forte presença do governo central nas políticas urbanas, a sobreposição de ações e intervenções dos governos, a descontinuidade das políticas públicas, o déficit institucional impedem maiores avanços na perspectiva do ordenamento territorial.

No capítulo dois, "Um breve histórico de estruturação de uma região: dos obstáculos naturais às contradições na estruturação da região", são abordadas as peculiaridades do sítio bastante hostil ao processo de ocupação e expansão da metrópole. Se a posição foi o fator determinante ao seu crescimento, as condições de sítio justificam as onerosas intervenções urbanas até os dias atuais. A configuração territorial baseada na dicotomia centro-periferia e a 
diferenciação na distribuição da infraestrutura urbana estão relacionadas às funções assumidas pela metrópole pela valorização da terra, que desencadeia a periferização da população de baixa renda e a favelização de múltiplos segmentos sociais. $O$ intenso processo de loteamento a que foi submetida a metrópole ao longo dos anos, resultou na extinção das áreas consideradas agrícolas e; consequentemente, na maior dependência da metrópole por produtos agrícolas.

O capítulo três, "Uma avaliação da construção política de uma região: da ausência de planejamento ao espaço segmentado e segregado", relata que a condição político-administrativa assumida pela cidade do Rio de Janeiro como Distrito Federal foi determinante na estruturação de seu território, principalmente pelos conflitos entre representantes políticos locais com relação às intervenções do governo central nas políticas urbanas locais. $O$ ideário de modernização do Distrito Federal impunha medidas radicais de remoção das favelas distantes e descontextualizadas das políticas de desenvolvimento urbano. O trabalho da SAGMACS sobre as favelas no Distrito Federal foi emblemático para as reflexões quanto à urgente inclusão desses espaços às políticas de ordenamento territorial urbano. A ausência de uma unidade de planejamento da cidade, gerou um descompasso dos objetivos dos planos urbanísticos, na sua grande maioria, apenas parcialmente implementados.

O capítulo quatro, "Uma região atípica ao ideário do planejamento integrado: os ideais nacionais e locais em jogo na metrópole", aborda o período em que a cidade do Rio de Janeiro deixou a condição político-administrativa de Distrito Federal e assumiu a condição de Estado da Guanabara. As perspectivas de ordenamento do território nacional e local se fizeram presentes. A sobreposição de órgãos do governo, de planos, leis e normas criou uma situação difusa quanto às políticas de ordenamento territorial urbanas. As intervenções urbanas nesse período reforçavam o papel do núcleo centralizador de bens e serviços urbanos. As políticas se voltaram para 0 processo de descentralização industrial e do controle do uso do solo. As relações conflituosas entre os representantes políticos locais e o governo central contribuíram para as interrupções e descontinuidades das políticas urbanas. O processo de descentralização administrativa do governo se expressou na própria subdivisão do território em regiões administrativas. As 
políticas direcionadas às favelas se caracterizaram pelas intervenções pontuais e desconexas, desde uma perspectiva maior de ordenamento territorial urbano. A fusão, considerada uma manobra estratégica do governo central, simbolizou o direcionamento das políticas de ordenamento territorial à tentativa de consolidar a região metropolitana com o apoio direto do governo central. Foram criados órgãos e fundos de recursos direcionados às políticas de desenvolvimento urbano que passaram a atuar com outros órgãos estaduais em articulação com o governo local no ordenamento territorial da metrópole a fim de desconcentrá-la e controlar os fluxos migratórios.

O capítulo cinco, "As ameaças do planejamento do desenvolvimento territorial: entre o planejamento e as intervenções imediatistas", relata as mudanças ocorridas na perspectiva do ordenamento territorial após a Constituição Federal de 1988, sob as influências dos processos de redemocratização e descentralização do governo da União. Os municípios assumiram um papel político importante no ordenamento territorial urbano. A sobreposição de planos, programas, leis e normas urbanísticas vêm gerando um quadro complexo às percepções e concepções do ordenamento territorial urbano. O plano diretor assumiu o papel político mais importante no ordenamento local que, de modo geral; substituiu os instrumentos urbanísticos anteriores. Por sua vez, outros planos, fora do contexto de planejamento do governo, foram elaborados com a finalidade de atender aos interesses diretos do setor privado empreendedorista. Novos modelos administrativos e intervencionistas são inseridos no discurso da competitividade local. As políticas direcionadas às favelas, desconexas de uma unidade política urbana, buscam na urbanização a utopia de inserir esses espaços ao contexto urbano ou adotam controle rígido de seu crescimento. Outros planos direcionam políticas urbanas baseadas no discurso de preparar a cidade aos eventos que estão por vir: a Copa de 2014 e as Olimpíadas de 2016. Na ausência de um projeto integrador de política urbana, assessorado por uma efetiva estrutura de planejamento, as ações e intervenções urbanas seguem descontextualizadas do planejamento do desenvolvimento territorial; de certa forma, corroboram o conjunto de ilegalidades e informalidades que agravam os problemas urbanos que por sua vez atingem toda a sociedade. 
A fim de avaliarmos as intervenções territoriais segundo o momento político e geopolítico do período da ditadura militar, demos início ao trabalho com o levantamento bibliográfico e de estudos que influenciaram diretamente ou indiretamente a racionalidade em todos os setores do governo e da sociedade direcionados à visão geopolítica do território, como no caso da ESGEscola Superior de Guerra e dos Planos Nacionais de Desenvolvimento- PND's no período desenvolvimentista. Encontramos vasto e diversificado número de publicações e obras da época ou referentes à mesma.

No âmbito da acelerada industrialização e urbanização do país, o ideário do ordenamento territorial consistia predominantemente em dispor de equipamentos sobre o território, o que, mesmo gerando tensões e desigualdades regionais, estimulariam a elaboração de políticas de ordenamento territorial baseadas no controle do uso do solo, considerando os problemas econômicos e sociais em relação ao solo e ao meio e a equidade regional. $\mathrm{O}$ ordenamento territorial urbano iria além do arcabouço legislativo e normativo que reforçariam a apropriação pelos interesses privados em detrimento de maior socialização do solo urbano.

O planejamento urbano e regional integrado consistia num conjunto de ações entre órgãos do governo, visando reduzir as distorções resultantes do acelerado crescimento das metrópoles, a partir da regionalização do Estado, da organização do sistema de cidades, do fortalecimento de centros urbanos do interior a fim de eliminar o desequilíbrio entre capital e núcleos interioranos, o indispensável suporte logístico à União em todos os programas e projetos federais e a ação conjugada estado-município em causas comuns.

Nosso primeiro diagnóstico seria de que os planos e programas idealizados e implementados no Estado da Guanabara e na capital do Estado do Rio de Janeiro, e as intervenções previstas e executadas; assim como, as políticas de obtenção de recursos e isenções fiscais às empresas privadas incluíam-se numa perspectiva geopolítica e estratégica de ordenamento do território urbano segundo uma racionalidade hegemônica nacional prevista nos Planos Nacionais de Desenvolvimento diante da realidade metropolitana do país.

Nosso segundo diagnóstico seria de que a perspectiva regional dos planos nacionais se deparava com os limites nas relações intergovernamentais [Digite texto] 
previstas na Constituição Federal, com o centralismo do governo federal e com os entraves institucionais para legitimar a realidade metropolitana do país. Diante do agravamento da crise econômica no mundo e interna do país, a perspectiva estratégica nacional e subnacional foram abandonadas pelo governo, dando lugar aos planos de estabilização monetária e financeira e novas influências políticas e tecnológicas que surgiam, apontando para outra concepção de ordenamento territorial urbano.

Embora possamos considerar as limitações impostas pelos fatores expostos acima, tal diagnóstico reforçou o aprofundamento de nossas reflexões quanto ao ordenamento territorial urbano e nos deu subsídios para o segundo momento do trabalho. Ao considerarmos mudanças no contexto político e econômico e nas políticas de ordenamento territorial urbano pudemos chegar a uma maior compreensão das políticas e ações no âmbito de uma racionalidade baseada nos princípios imediatistas liberais, na redução do papel do governo, numa administração pública descentralizada, no rígido controle do orçamento público, no planejamento participativo e sustentável e no fortalecimento do município como unidade político-administrativa para impulsionar 0 desenvolvimento local, regional e nacional.

No âmbito da redemocratização do país nos anos de 1980, e diante dos novos arranjos territoriais provenientes das inovações tecnológicas; uma maior visibilidade das reivindicações sociais, reformas políticas do governo e do setor privado diante das intensificações das relações econômicas no mundo e exigências do cumprimento politico indicadas pelas instituições mundiais ligadas às questões sociais e ambientais, novas concepções do ordenamento territorial urbano passaram a predominar e a determinar diretrizes de leis e normas, assim como dos planos e programas de governo.

O ordenamento territorial urbano centralizado pelo governo federal foi se desmembrando entre as esferas do governo, tendo em destaque o município, que pelo menos em tese adquiriu competência para ordenar seu território como disposto no título dedicado à política urbana da Constituição Federal de 1988. A regulamentação do artigo pertinente, anos depois, culminou na obrigatoriedade de elaborar o plano diretor como instrumento fundamental do planejamento local e corroborou o ideário dominante, no conteúdo relacionado 
aos instrumentos de uso e controle do solo urbano no Estatuto da Cidade em 2001 e na criação do Ministério das Cidades em 2003.

Atualmente as mudanças nos paradigmas que regem o processo de produção, apropriação e expropriação do espaço urbano expressas nos planos estratégicos se sobrepõem às diretrizes do ordenamento territorial expressas no plano diretor, considerado principal instrumento de planejamento e controle do uso, do parcelamento e da ocupação do solo urbano. A sobreposição de planos estratégicos intervencionistas imediatistas desprovidos dos princípios de planejamento, plano diretor, leis e normas urbanísticas contribuem para 0 quadro complexo e por vezes confuso relativos às políticas de ordenamento territorial.

O processo de estruturação e consolidação da Metrópole do Rio de Janeiro reflete os mais intensos conflitos de interesses quanto ao uso e ocupação do solo urbano, resultando na perda expressiva de recursos públicos a partir dos incentivos e isenções oferecidos ao setor empreendedorista e no elevado custo aos cofres públicos nas intermitentes políticas intervencionistas contidas nos grandes projetos urbanos. Os programas direcionados à inserção das favelas no contexto urbano despendem quantias elevadas dos cofres públicos sem se inserirem numa perspectiva maior de ordenamento territorial. Os problemas urbanos se agravam e os instrumentos legais capazes de direcionar as políticas de ordenamento territorial tornam-se excessivos e ineficazes nesse processo. 


\section{PARTE 1- BASES CIENTÍFICAS PARA UMA RACIONALIZAÇÃO, INTEGRAÇÃO E CONSTRUÇÃO DO ESPAÇO URBANO E REGIONAL.}

\subsection{Capítulo 1 - O ordenamento territorial: a construção de um ideário}

Nesse primeiro capítulo do trabalho, analisa-se inicialmente o ideário do ordenamento territorial que se implantou, internacionalmente, nos anos seguintes ao término da Segunda Guerra Mundial e que teve a sua origem na própria economia política, buscando garantir a produção, a acumulação, a circulação e a distribuição de riquezas territorialmente nas sociedades de diferentes graus de desenvolvimento. O ideário do ordenamento territorial, cuja origem está na racionalidade da economia política, desencadeou as bases físicas para a produção e distribuição de riquezas em diversas regiões no contexto de uniformização das técnicas e pensamentos de atuar sobre 0 território.

Muitos autores buscam sintetizar o ordenamento territorial como ciência, técnica e política de atuar sobre um determinado território a fim de impor uma ordem capaz de atenuar as disparidades sociais e econômicas inter-regionais resultantes das relações capitalistas ao longo dos anos. As primeiras concepções do ordenamento territorial surgiram no contexto estratégicogeopolítico pós Segunda Guerra Mundial, inscrito no período da Guerra-Fria, de acentuadas rivalidades ideológicas, e de reafirmação das relações capitalistas no mundo.

O ideário do ordenamento territorial surgiu em contraponto aos ditames da expansão das relações capitalistas no mundo. Num viés ortodoxo das relações capitalistas em expansão, a tendência seria a reprodução do capital de modo desigual sobre o território que resultaria nas disparidades sociais e econômicas entre regiões. Em contraponto a essa tendência, o ordenamento territorial seria uma alternativa para corrigir essas disparidades permitindo a expansão das relações capitalistas, buscando a funcionalidade do território e o bem-estar de seus habitantes. 
Mas, o que é ordenamento territorial? Consideramos o ordenamento territorial como uma função essencialmente pública e política que lança mão de variáveis que contribuem para maior amplitude conceitual da referida categoria, que se mostra bastante complexa. Ao passo dos novos conceitos de desenvolvimento e das influências internacionais, o ordenamento territorial foi agregando variáveis no âmbito político, tecnológico e cultural sem se desfazer de sua concepção original.

A princípio, o ordenamento territorial apoiar-se-ia sobre o quadro natural que constituiu o espaço geográfico em escala local, sobre os processos sociais, culturais, ambientais e econômicos que produziriam formas concretas de ocupação e utilização do espaço; sobre análise e interpretação de informações estatísticas locais, sobre representações do espaço multiescalar; sobre a relação do comportamento humano com as potencialidades naturais e suas repercussões; sobre a integração de manifestações ou fenômenos locais em cenários naturais, sociais e econômicos de maior escala; sobre instrumentos jurídicos (acordos internacionais, constituições, leis, normas e decretos) que condicionam a dinâmica do território; sobre práticas administrativas e princípios consolidados (planejamento, participação, etc.) e; sobretudo na prática científica multidisciplinar (porque agrega visões de múltiplos atores), assim como interdisciplinar (porque permite interagir interesses entre atores em busca de conciliá-los), sem, contudo deixar de ser disciplinar enquanto técnica com bases científicas.

$\mathrm{O}$ ordenamento territorial adquiriu características de disciplina científica, de técnica administrativa e de política numa expressão espacial da política econômica, social, cultural, ecológica de toda a sociedade, tendo por objetivos principais o uso adequado dos recursos, o desenvolvimento, a funcionalidade do território e o bem-estar ou qualidade de vida dos cidadãos. Assim, a prática do planejamento no ordenamento territorial agregaria novos elementos a serem considerados; fato este que, de certa forma, implicaria em estudos bem elaborados da realidade a ser ordenada e a presença de profissionais capacitados em lidar com novas variáveis em todos os níveis de governo num sistema de planejamento.

O ideário do ordenamento que se expandiu em alguns países do Terceiro Mundo no período pós Segunda Guerra Mundial simbolizou rupturas [Digite texto] 
aos próprios efeitos da exploração capitalista entre nações e suas consequências maléficas à condição humana. Teve na pessoa de J. L. Lebret e sua doutrina "Économie et Humanisme" um contraponto à racionalidade de reprodução capitalista, que degradava as condições mínimas de vida de muitos povos. É de notar sua grande influência no ordenamento territorial no Brasil. $O$ ordenamento territorial lebretiano opor-se-ia a toda forma de exploração humana no mundo, baseando-se no respeito à pessoa humana em todos os aspectos materiais e espirituais; o respeito e a promoção do bem comum seriam princípios vitais de ascensão humana. Esses princípios inspirariam os objetivos e as modalidades de ordenamento territorial, em especial no Brasil.

No contexto da ampliação das relações capitalistas entre os diferentes grupos de países, o processo de ordenamento territorial exigiria o estudo de diversas estruturas físicas, econômicas e sociológicas do território, visando o pleno desenvolvimento da população e seu bem-estar. As políticas de ordenamento territorial deveriam visar sempre à valorização humana. Todo crescimento econômico de um determinado país deveria ser acompanhado pela melhoria das condições de vida principalmente das camadas menos favorecidas da sociedade (Lebret, 1952).

O ordenamento territorial, com base na experiência da França, repousaria sobre uma tensão, um equilíbrio entre relações comunitárias e relações societárias. O ordenamento territorial lebretiano seria uma construção democrática ascendente que privilegiaria a região e exigiria um poder político descentralizado e bem informado, suficientemente forte para deixar as comunidades subordinadas ao máximo de liberdade sem comprometer a unidade e equilíbrio da nação. Seria necessário começar pelo ordenamento nas comunidades territoriais de base para estender pouco a pouco até a nação e até o mundo. Assim, a ordem total seria uma ordem sempre constituída do homem que se poderia dizer piramidal, fortemente apoiada sobre blocos sólidos de uma base larga (Houée, 1997:p.93).

O ordenamento territorial necessitaria de uma organização política que exigiria a formação de novos responsáveis e a elevação progressiva de massas, dando às unidades territoriais de base e intermediárias o máximo de autonomia. Tal autonomia seria, necessariamente, compatível com o equilíbrio nacional, dobrando a representação necessária das políticas correntes pelos 
grupos familiares, profissionais, culturais e das coletividades territoriais autônomas, recentralizando o governo no seu papel de coordenador do conjunto e de último árbitro. No grande projeto lebretiano, ordenamento comunitário e economia humana seriam indissociáveis e interagentes (Lebret, 1958).

O ordenamento territorial, prioritariamente na escala regional, teve por base a dinâmica dos fluxos de mercadorias, capitais e pessoas numa determinada região, que dependeria de elementos de infraestrutura fixos e móveis para garantir o processo de industrialização, circulação e consumo e consequentemente de desenvolvimento. A ideia de ordenamento territorial surgiu tendo por base a organização do espaço econômico, e acabou servindo garantir a expansão das relações capitalistas no mundo.

A princípio, o ordenamento territorial surgiu com o ideário de ordenar, ou melhor: de "dispor com ordem" valendo-se dos recursos dispostos e disponíveis no território. Tal concepção por si só chegou a gerar inúmeras desigualdades e disparidades entre regiões. O ordenamento territorial como discurso surgiu da necessidade de conciliar os conflitos oriundos dessas desigualdades e disparidades entre regiões ricas e pobres refletidas no antagonismo de classes que ia se acentuando com o desenrolar da evolução econômica e pondo a própria unidade territorial em risco. Medidas deveriam ser tomadas pelos governos para alcançar maior equilíbrio entre regiões e ao mesmo tempo dar continuidade ao processo de desenvolvimento. A proposta do ordenamento territorial acima de tudo estaria em dispor de mecanismos de todas as naturezas para manter a ordem e garantir o bem-estar da população.

No contexto de expansão das relações capitalistas e das unidades produtivas, e na concepção do ordenamento territorial que predominou nos anos 60 e 70, os responsáveis pelo planejamento do desenvolvimento territorial deveriam dispor de equipamentos por sobre o território em destaque, de forma a viabilizar a circulação dos fluxos que garantiriam maior rentabilidade imediata, mesmo acentuando o processo acumulativo, as tensões e as desigualdades regionais que se faziam sentir desencadeando certa desordem do território. As tensões regionais estimulariam a elaboração das políticas de ordenação do território e as bases reais da ordenação do território passariam por uma profunda análise nas leis de uso do solo, e pensando não apenas nas 
políticas tributária e fiscal entre os entes federativos que poderiam reforçar o controle do uso do solo. Defendia-se que as políticas para o espaço territorial deveriam considerar os problemas econômicos e sociais em suas relações com o solo e o meio (Labasse; 1960).

Portanto, o objetivo principal do ordenamento territorial seria dispor equilibradamente os habitantes e as atividades econômicas sobre o conjunto do território em diferentes escalas no decorrer do tempo. Tratava-se de o governo responder obrigatoriamente à expansão das relações econômicas no mundo e às inovações científico-tecnológicas de todas as ordens a partir da racionalização na organização das atividades sobre o território.

Assim, o governo lançaria mão dos instrumentos institucionais jurídicos e administrativos para que, de forma intencional, o poder público pudesse, a partir deles, interferir soberanamente sobre a propriedade, os equipamentos e o uso e controle do território a fim de otimizar o emprego dos recursos naturais e justificar a escolha orçamentária em um determinado setor, utilizando-se do discurso de redução dos desequilíbrios e desigualdades entre regiões e do alcance de benefícios a todos da sociedade.

Reduzir as disparidades regionais sob o ideário do equilíbrio interregional, a priori seria a base da racionalidade que se implantou, justificando as intervenções do governo sobre o território, alocando equipamentos e investimentos de modo a distribuí-los equilibradamente sobre o espaço. A concepção geométrica do espaço e a disposição dos equipamentos e investimentos por sobre o espaço atenuaria os desequilíbrios regionais e as regiões sofreriam um ordenamento que, por si, desencadearia inúmeras mudanças nos campos administrativos, tributário e fiscal, político, jurídico, econômico e social. A apropriação do espaço, expressa nos grandes conflitos, teria no papel do governo e dos instrumentos jurídicos os meios de impor uma ordem ou desordem ao território.

$\mathrm{O}$ ordenamento territorial adquiriu um formato institucional pelos inúmeros desdobramentos de seu propósito inserido numa lógica hegemônica expressa nas constituições, estatutos, leis, normas, decretos, planos, programas e projetos orientados pelo governo. Tais instrumentos de ordenamento territorial tornaram-se a expressão dos conflitos de interesses dos grupos sociais ao longo dos anos; e havia a suposta intenção de conciliá-los e [Digite texto] 
reduzir as tensões regionais. As tensões regionais estimulariam a elaboração das políticas de ordenamento territorial e as bases reais do ordenamento territorial estariam nas leis de uso e controle do solo e nas políticas tributária e fiscal.

Então, tal propósito de ordenar o território não estaria restringido apenas ao poder público, mas, o mesmo seria considerado como único capaz de reunir os meios necessários para otimizar o emprego dos recursos naturais ou de atenuar os considerados desequilíbrios e desigualdades regionais a favor do interesse geral da nação ${ }^{4}$. Os meios necessários para o poder público elaborar políticas de ordenamento do território se legitimavam no conjunto de instrumentos institucionais e no discurso de equilíbrio do território sob os argumentos do interesse geral que não necessariamente compactuava com os interesses local e regional.

As acentuadas disparidades regionais estavam ligadas principalmente ao processo de industrialização e urbanização dos países. O ordenamento territorial urbano surgiu da necessidade de controle social, político e econômico expressos espacialmente nas metrópoles com relação a sua região de influência, a fim de garantir a expansão das relações capitalistas entre diferentes grupos de países. Diante dos novos arranjos territoriais, o ordenamento territorial urbano impunha a junção de aspectos físicos, econômicos e sociais numa perspectiva racional de crescimento econômico e desenvolvimento sob um sistema regional integrado.

Um dos maiores desafios para o ordenamento territorial urbano estaria nos problemas relacionados à propriedade do solo. Os problemas estariam relacionados aos interesses privados de se extrair lucro na apropriação do solo urbano nos países de economia de mercado; e nos países socialistas, mesmo possuindo maiores condições de controle do uso do solo, sofreriam da mesma

\footnotetext{
${ }^{4}$ Segundo Lefebvre (2003, p.55), a referência a um interesse geral superior aos interesses particulares locais serve de álibi às lacunas do pensamento fundador do ordenamento e do desenvolvimento territorial. Invocar o interesse geral pode ser uma escapatória à reflexão e permitir ignorar os dados reais dos problemas, não se aprofundando neles, tratando-os superficialmente. Então é preferível não invocar "o interesse geral" pela facilidade política e comodidade intelectual, como um álibi às falhas de análise das causas dos problemas territoriais. O ordenador deve estar permanentemente capaz de identificar e avaliar "os interesses superiores" comuns e concretos aos diversos níveis senão sua intervenção sobre o território não tem objetivos fundamentais nem legítimos nem mesmo autenticamente legais.
}

[Digite texto] 
forma as pressões oriundas dos interesses de mercado. Valendo-se de suas experiências sobre 0 ordenamento territorial urbano, Jean Labasse (1960:p.338) constata que:

Los problemas de la propiedad de la tierra dominan el conjunto de la planificación urbana, ya que "a plusvalía" es, en países de economía liberal, uno de los principales factores de evolución y diferenciación del paisaje urbano. Sin duda, estamos en el punto en que la organización del espacio está más estrechamente sujeta a los sistemas de gobierno. En efecto, sólo la ciudad de los países socialistas queda libre de las servidumbres de la renta rural y goza por ello de gran libertad de estructura y de zonificación, sin que haya que ignorar por ello los posibles abusos que se derivan de la concesión incontrolada de la autorización para construir. ${ }^{5}$

O ordenamento territorial se fazia necessário diante da realidade das tamanhas aglomerações urbanas e do acelerado processo de urbanização no planeta, bem como do acelerado dinamismo econômico no mundo, comandado pelas empresas que aprofundavam as relações interdependentes $\mathrm{e}$ as dissimetrias tanto entre regiões de um determinado país como no plano internacional entre países. O processo de industrialização seria o fator responsável pelas grandes desigualdades regionais. No entanto, a aceleração das desigualdades sócio-econômicas desencadearia conflitos que poria em risco a unidade nacional dos países (Boudeville; J. 1972).

Numa visão instrumentalizadora e baseada nos fluxos de bens, serviços e pessoas no espaço, Boudeville propunha ordenar o território a partir da "teoria dos pólos de crescimento", o que a princípio diminuiria as desigualdades entre regiões e poderia ter aplicação em qualquer economia. 0 desenvolvimento regional não dependeria somente das migrações de homens e capitais, mais também de transmissão das novas descobertas tecnológicas que tratariam da transformação material ou da organização humana. As

\footnotetext{
${ }^{5}$ Os problemas da propriedade da terra dominam o conjunto do planejamento urbano, já que "a maisvalia" é, em países de economia liberal, um dos principais fatores de evolução e diferenciação da paisagem urbana. Sem dúvida, estamos no ponto em que a organização do espaço está mais estreitamente sujeita aos sistemas de governo. De fato, só a cidade dos países socialistas é livre das servidões da renda rural e goza por isto de grande liberdade de estrutura e zoneamento, sem que tenha que ignorar por isto os possíveis abusos que se derivam da concessão incontrolada da autorização para construir.
}

[Digite texto] 
unidades tecnológicas seriam diferentes e desiguais entre si no que diz respeito a sua capacidade de receber, de criar e de transmitir informações. As mensagens não seriam lançadas no espaço uniformemente, e o número de receptores potenciais seriam maiores numa região que em outra. As políticas regionais deveriam basear-se na especialização de atividades.

A partir de uma análise dos fluxos entre as cidades, seria definida uma hierarquia e consequentemente os pólos de crescimento e de desenvolvimento da região. O ordenamento territorial partiria de análise numérica e geométrica do espaço que permitiria um equilíbrio dos fluxos e das migrações intraregional e inter-regional. Nesse caso, as noções de crescimento, de desenvolvimento e de progresso faziam parte da dinâmica do processo de desenvolvimento. O processo de polarização dependeria da infraestrutura física e da complementaridade entre as atividades econômicas de uma determinada região. A cidade, a região ou a nação seriam como um sistema imbricado em vias de evolução (Boudeville, 1972).

O grande problema na aplicação da "teoria de Boudeville" nos países subdesenvolvidos, baseada no desenvolvimento regional integrado, estaria no desconhecimento de dados geográficos e econômicos das regiões, no deficiente sistema regional de comunicações, na insuficiente quantidade de recursos destinados às pesquisas, no reduzido número de grandes empresas e de instituições científicas governamentais, e de outros diversos fatores que diferenciavam as regiões do ponto de vista do crescimento e determinavam a polarização do espaço econômico.

Pelo estudo do embasamento teórico do trabalho, o ideário do ordenamento territorial que se instalou no Brasil estava atrelado ao processo tardio de industrialização que proporcionaria avanços no desenvolvimento e bem-estar da população. As metrópoles e as aglomerações urbanas eram consideradas obstáculos para o ordenamento territorial e, portanto, dever-se-ia lançar mão de medidas e instrumentos capazes de controlar a pressão sobre 0 solo urbano. O ordenamento territorial tinha por base a integração do território nacional e o equilíbrio na distribuição de pessoas e infraestrutura como fatores imprescindíveis para um desenvolvimento harmônico e bem-estar dos habitantes. 
A análise do ordenamento territorial que se segue, no próximo capítulo, tem por base as novas influências que surgiram com os avanços científicos, tecnológicos, políticos e geopolíticos mais recentes, que contribuíram para novas percepções e concepções acerca do ordenamento territorial, que não se desfez de suas concepções originais, mas propõe novos posicionamentos e agrega novas variáveis ao planejamento do desenvolvimento territorial. 


\subsubsection{O ordenamento territorial: o ideário sob novas influências}

Após tantas mudanças no âmbito político e econômico das relações sociais nas últimas décadas, que influências o ordenamento territorial sofreria?

Ao passo dos novos arranjos territoriais com base nos avanços científico-tecnológicos no contexto da máxima internacionalização econômica e dos novos atores e interesses em questão no contexto da democratização dos meios participativos e de novas reflexões quanto ao papel do governo, mudanças foram inseridas na concepção do ordenamento territorial. Assim, não mais se justificaria o discurso de reequilibrar o território com base nos dados aritméticos e estatísticos porque apenas os índices não poderiam dar a medida e nem permitiriam a avaliação da situação concreta dos habitantes.

Outras percepções foram acrescidas à concepção original da teoria de desenvolvimento espacial expressa no ordenamento territorial. É o caso das questões ambiental, cultural e demográfica; da visão geopolítica regional; da estabilidade monetária e controle financeiro; da necessidade de redução de custos; do desenvolvimento tecnológico e informacional; da elaboração de bancos de dados regionais, da descentralização das atribuições governamentais entre os entes federativos, o federalismo, todos considerados de forma a garantir o crescimento econômico e o desenvolvimento a partir de uma política de integração regional, sob os novos paradigmas da máxima internacionalização econômica do mundo.

Diante da racionalidade aplicada ao espaço a que nos referimos anteriormente, à idéia de organização do espaço sob uma perspectiva regional que buscava melhor disposição dos elementos físicos no espaço avançou conceitualmente até o ordenamento territorial composto da interação dos aspectos naturais, físicos, culturais, econômicos e geopolíticos de uma determinada região, acrescida conforme a complexidade dos conflitos que desencadeariam muito mais uma desordem do que uma ordem propriamente dita. O ordenamento territorial adquiriu uma conotação muito além de uma simples característica dos governos que é o de saber fazer política conciliando posições e opiniões diversas e até antagônicas. 
O ordenamento territorial, resultante da concepção utópica de igualdade de territórios ${ }^{6}$, baseou-se em diferentes disposições de recursos naturais e a alocação determinista dos investimentos produtivos sobre o território que resultariam em acentuadas desigualdades sociais, econômicas e demográficas entre regiões e refletiriam nas chamadas tensões sociais que desencadeariam inúmeros conflitos. Os conflitos oriundos das desigualdades sociais e econômicas poriam em risco a unidade nacional do país com a dissociação e subdivisão do território sob o impacto das tensões e dos problemas nas escalas locais, regionais e nacionais.

Resumindo: o ordenamento territorial tem por objetivo incluir todas as relações que ocorrem sobre determinado espaço na perspectiva de conciliar os conflitos. O ordenamento territorial tornou-se um campo de conflitos. Um dos principais desafios ao ordenamento territorial estaria na arte de conciliar conflitos oriundos da própria dinâmica dos diversos atores e interesses que se entrecruzam sobre um determinado território.

No processo de evolução da concepção do ordenamento territorial, consideramos que a noção de territórios apreendida neste trabalho e submetida ao ordenamento foi acrescida ao longo dos anos não apenas pela noção de espaço em que um ator exerce poder (Raffestin, 1993), nem tampouco pela noção de identidade ou de espaço relacional simbólico apenas, mas, se refere principalmente ao território submetido ao ordenamento tratado na sua complexidade. O território de intervenção vê-se composto por diversas territorialidades que se superpõem a partir de diversas "desterritorializações" e "multiterritorialidade" em diversas dimensões e escalas (Haesbaert, 2004) cujas verticalidades e horizontalidades das relações sociais (entre múltiplos atores que se estabelecem ao mesmo tempo) se entrecruzam e de forma bastante conflituosa se coadunam sobre o espaço no mundo globalizado (Santos, 1999).

\footnotetext{
${ }^{6}$ Segundo Lefebvre (2003: p.45) o conceito de igualdade de territórios tem um porte normativo incerto ao que concerne o ordenamento territorial e é derivado de dois princípios constitucionais de igualdade dos cidadãos diante da lei e da igualdade dos direitos entre as pessoas. O conceito de igualdade de territórios aproxima ao de equilíbrio de territórios e refere-se muito mais a uma análise matemática de números entre si e pouco atende as análises das ciências morais, sociais e jurídicas. Análise numérica não se aplicaria às ciências sociais porque as diferenças numéricas não seriam capazes de avaliar as causas e efeitos nem qualificá-los.
}

[Digite texto] 
No entanto, os conflitos daí gerados podem ocorrer em diversas escalas territoriais: da escala nacional para alguns conflitos emblemáticos à escala local ou micro local, passando pelo nível regional, segundo os atores envolvidos. Os conflitos tornaram-se uma realidade do ordenamento. Os conflitos de competitividade entre os territórios se multiplicam a partir da intensificação das relações capitalistas no mundo, na vulnerabilidade do papel dos governos nacionais na localização das unidades produtivas, na geração de empregos, nas ações estratégicas das empresas e nos projetos de investimentos. A razão do conflito entre os múltiplos atores está em exercer um controle sobre um território ou na forma de apropriação deste território.

Ao ser definido o território como um espaço apropriado por um ator (Rafestin, 1993) ou por constituir-se como um objeto de apropriação que envolve um ou múltiplos atores, o seu controle passaria não apenas pelo controle político ou pelo controle militar ou da propriedade política do solo, mas, o controle passaria pela aplicação de outras regras jurídicas, por exemplo: das regras de proteção que limitam o uso do solo ou que incentivam sua subdivisão ou pela não-aplicação dessas regras que, ao inverso, garantiriam a apropriação, que é o controle de fato (mesmo que não de direito).

$\mathrm{Na}$ realidade, no desenrolar das idéias, o controle ocorre a partir das definições quanto ao uso do solo. Ou seja: ocorrerá apropriação quando um ator passar a usar o espaço em função de suas necessidades e seus interesses. O controle permite o uso do espaço e o uso permite determinar quem exerce controle sobre o espaço. $O$ conflito nasce da confrontação entre diversos projetos de apropriação (ou de uso) concorrentes, de atores distintos, com projetos parcialmente ou totalmente incompatíveis.

O ordenamento territorial passou a ser acima de tudo uma questão política e geopolítica porque abarca de forma conflituosa diferentes interesses dos diferentes grupos sociais apesar de ter sido reduzido a uma realidade técnica ao longo dos anos, mas nunca negando seu caráter geopolítico. As operações do ordenamento concretas ou as políticas de ordenamento podem ser objeto de conflitos entre os atores sociais e refletem as divergências de interesses, de culturas ou de estratégias. $O$ caráter multidisciplinar que 0 ordenamento territorial adquiriu, permitiu desenvolver uma doutrina do ordenamento. Embora difícil, o ordenamento territorial deveria ser pensado sob 
um ângulo político ou geopolítico, o que se tornaria uma questão epistemológica interessante (Subra, 2007).

O ordenamento territorial não se relaciona mais à escolha soberana de um único agente ordenador do território, particularmente o governo, de impor uma ordem de forma soberana sobre a escala nacional ou local. O desafio do ordenamento territorial está em conciliar o processo de discussão, reflexão e decisão dos posicionamentos em conjunto de todos os participantes da sociedade, dos ordenadores públicos e privados, dos grandes atores econômicos e agentes do quotidiano. O processo de discussão, reflexão e decisão dos diferentes atores políticos, pode permitir ao governo identificá-los, desenvolver uma metodologia apropriada e uma explicação mútua dos conflitos declarados e das expectativas em questão. Atualmente, mediação, arbitragem e conciliação são os meios mais eficazes desse processo.

É interessante tomar a obra de Subra (2007), que apresenta uma concepção do ordenamento territorial que considera a capacidade de conciliar diversos conflitos de interesses que se coadunam sobre o território. Ordenar o território não seria apenas como um trabalho de especialistas, mas, principalmente um trabalho baseado num bom diagnóstico e de operações bem pensadas. Assim, o ordenamento territorial no contexto de uma maior participação dos grupos sociais nas decisões políticas consensuais tornou-se uma questão política que agrega relações de forças, de rivalidades políticas, de afrontamentos entre projetos concorrentes ou entre grupos de pressão ou simplesmente exprimem os interesses divergentes dos atores múltiplos. Reitere-se: o ordenamento territorial seria uma questão acima de tudo geopolítica.

A evolução científico-tecnológica, a intensificação das relações capitalistas, as mudanças do papel do governo, a democratização de países, novos atores políticos em cena, as reformas do governo em função da falência dos modelos antigos e ultrapassados de administração pública, a descentralização das competências do governo e a municipalização das políticas públicas, levaram o ordenamento territorial a se transformar numa ação acima de tudo de conciliação dos diferentes conflitos de interesses.

No Brasil, o discurso de equilibrar o território não convence mais em afirmar que determinado território encontra-se em desequilíbrio e a partir desta [Digite texto] 
constatação a sociedade e as empresas estariam ameaçadas porque determinadas pessoas podem apresentar condições favoráveis de vida numa zona considerada desfavorecida do ponto de vista econômico e social. O discurso de equilíbrio de território influenciou o arcabouço de leis e normas que se tornaram excessivas e incapazes de qualificar a realidade nos pormenores e de fundamentar a ação do poder público no ordenamento territorial. O discurso dos desequilíbrios e desigualdades entre regiões não mais justifica as políticas de ordenamento do território indicando revisões dos instrumentos jurídicos e administrativos.

O ideário do ordenamento territorial permitiria rever os parâmetros estatísticos que direcionam os investimentos produtivos e em infraestrutura básica de vida da população que ocupa um determinado território. O desequilíbrio entre regiões estaria muito mais associado à ausência de investimentos públicos assim como à desigualdade de condições de acesso aos bens e serviços públicos assim como o direito à moradia. De modo contínuo, a política de ordenamento territorial urbano permitiria ao governo identificar os conflitos de interesses, as deficiências jurídicas e administrativas em lidar com o intenso processo de segregação social do espaço urbano, os aspectos positivos e negativos da política urbana, o suporte necessário orçamentário para os investimentos urbanos, entre outros indicativos.

Em contraposição ao apriorismo conceitual do ordenamento territorial em amenizar os grandes conflitos a partir da socialização do solo urbano, revendo leis de uso, controle e zoneamento do solo e as políticas tributária e fiscal, o ordenamento territorial não se restringe apenas a racionalizar o uso do solo urbano, segundo as administrações técnicas locais, mas, abrange outras variáveis novas e indeterminadas que afetam as relações de pessoas, de empresas, de organizações coletivas entre elas próprias e o território. A evolução das relações sociais e os conflitos daí gerados não são acompanhados pela evolução institucional. Os instrumentos jurídicos e administrativos não são suficientes na proposta do ordenamento territorial diante da realidade complexa das relações sociais sobre o território.

Hoje, a despeito da emergência de um direito do ordenamento territorial, a fragmentação de leis que se encontra no caso específico da França, traz à política de ordenamento e desenvolvimento do território, princípios e conceitos [Digite texto] 
novos susceptíveis de modificar profundamente o ordenamento territorial, suas instituições e o modo de ordenar. Lefebvre (2004: p.214) sintetizou o ordenamento territorial numa visão renovada sem se desfazer de suas origens:

L'aménagement doit alors privilégier, entre autres finalités, celle de donner a logistique territoriale au développement économique et social, ce qui met em concurrence, voire em conflit, les objectifs égalitaires de l'aménagement du territoire et les impératifs de sélectivité territoriale qui commandent au développement. II est fait d'opportunités saisies grâce aux moyens localement disponibles et ceux-ci ne peuvent pas être les mêmes partout, même quand ils sont distribués par l'Etat de façon symétrique. ${ }^{7}$

O propósito do ordenamento territorial urbano permitiria avaliar a sobreposição entre as determinações quanto ao uso, controle e zoneamento do solo urbano disposto nos planos diretores, enquanto relevante instrumento de planejamento do município e as determinações dispostas nos grandes projetos urbanos. Embora ambos merecessem maiores reflexões, o plano diretor e os projetos urbanos são instrumentos importantes no direcionamento das intervenções urbanas e na reformulação das leis e códigos urbanísticos que determinam a apropriação, a expropriação e a expansão do espaço territorial urbano. O ordenamento territorial urbano, enquanto processo político contínuo, permitiria uma conjugação entre plano diretor e projetos urbanos identificando e conciliando novos conflitos e os interesses dos novos atores políticos em questão e novas oportunidades permitiriam reformas nas leis e códigos urbanísticos necessários.

A atual política de ordenamento e desenvolvimento do território aponta urgentes reformas no governo, descentralização das competências pelas instâncias do governo de modo democrático e integrado a fim de otimizar bens e serviços públicos oferecidos à população, assim como avançar nas práticas

\footnotetext{
7 - O ordenamento deve então privilegiar, entre outras finalidades, a de oferecer a logística territorial ao desenvolvimento econômico e social que põe em concorrência e em conflito, os objetivos igualitários do ordenamento do território e os imperativos de seletividade territorial que comandam ao desenvolvimento. É fato de oportunidades tomadas graças aos meios localmente disponíveis e aqueles que não podem os mesmos para tudo, mesmo quando eles estão distribuídos pelo Estado de modo simétrico.
}

[Digite texto] 
administrativas públicas que considerem os novos arranjos territoriais e a revisão do arcabouço jurídico, administrativo e normativo, definindo os objetivos econômicos e sociais fundamentais adaptáveis às realidades locais.

De modo que se crie um embasamento ao trabalho que se apresenta, o desenrolar das idéias sobre ordenamento territorial nos oferece os subsídios necessários para as reflexões que se apresentam. Não temos a intenção de esgotá-lo e muito menos defini-lo pela tamanha complexidade com que se apresenta, o ordenamento territorial urbano nos permite uma visão mais completa das relações e interesses que predominam na apropriação, expropriação e estruturação do espaço em estudo.

Em nossa escala de análise, o ordenamento territorial é concebido como uma questão geopolítica tanto quanto técnica, política e científica, e o território como um espaço onde se coadunam as relações de poder. Numa concepção geopolítica, sem deixar de lado as concepções geográficas, considerando a inter-relação entre elas, o ordenamento territorial nos proporciona compreender de forma mais eficaz os conflitos dos arranjos espaciais, elaborar diferentes cenários ou diferentes respostas possíveis. Outros aspectos em nossa análise; tendo o desenvolvimento regional e o urbanismo numa perspectiva geopolítica, deverão permitir a visão de relações complexas e ao mesmo tempo de complementaridade do ordenamento territorial na Região Metropolitana do Rio de Janeiro.

Neste caso, pretende-se reconhecer uma nova racionalidade que se impõe diante das mudanças no âmbito político e econômico das relações sociais no mundo. Novas percepções e concepções do ordenamento territorial indicariam reformulações e inovações de instrumentos jurídicos e administrativos e de práticas administrativas acima de tudo políticas para se adequarem às grandes transformações e mudanças das relações sociais expressas territorialmente. Diante de uma nova proposta de ordenamento territorial que não se desfez de suas concepções originais, vale a seguir deterse no estudo das influências estrangeiras que definiram o quadro de sobreposição de racionalidades na perspectiva do desenvolvimento territorial. 


\subsection{Capítulo 2 - As influências estrangeiras no ordenamento territorial no Brasil: adaptando racionalidades à realidade do país.}

A concepção do ordenamento territorial introduzida nos países latinoamericanos surgiu após a Segunda Guerra Mundial, e inseria-se numa ordem mundial entre diferentes grupos de países que estariam sob o domínio e entregues a uma geopolítica maior de rivalidades ideológicas e de reafirmação do sistema capitalista no mundo. A América Latina se reafirmava geopoliticamente como uma região de influência direta dos Estados Unidos, a partir dos grandes investimentos reforçados pela lógica do desenvolvimento.

Alguns acordos foram determinantes na concepção do planejamento para o desenvolvimento dos países latino-americanos. É o caso da Carta dos Andes - Bogotá 1958, que teve forte influência na introdução do planejamento como uma técnica apoiada numa racionalidade e cientificidade de propostas elaboradas para se chegar às melhores soluções. Diante de uma realidade complexa das cidades latino-americanas, a concepção do planejamento urbano introduzida adquiriu caráter técnico, científico e neutro apoiado numa miríade de conhecimentos sobre a realidade urbana e capaz de propor as melhores soluções para os diversos problemas e conflitos urbanos. Ações e intervenções do governo seriam legitimadas pelos planos e projetos.

A concepção do planejamento expressa em planos e projetos que legitimam as intenções políticas sob um caráter técnico, científico e, acima de tudo, político, levou os países desenvolvidos, principalmente os Estados Unidos a reconhecer oficialmente que a atuação planejada dos governos na economia representaria uma garantia para seus investimentos e transações estratégicas com os países latino-americanos. O planejamento governamental passou a ser aceito e adotado pelos países capitalistas como uma técnica de aplicação de políticas e principal prática para alcançarem seus objetivos.

No caso do Brasil, no contexto das influências norte-americanas exercidas no sentido de afastar qualquer ameaça comunista na América Latina; após a Revolução Cubana e ascensão de Fidel Castro ao poder em 1959, foram intensificados fluxos de empréstimos financeiros ao país de modo a empregá-los no processo de crescimento econômico e modernização. O 
objetivo principal dos Estados Unidos em assistir aos países latino-americanos era criar uma visão global de desenvolvimento na região a partir de investimentos em infraestrutura, assessoria nos avanços institucionais e na estabilidade política e econômica desses países a fim de garantir o retorno no processo expansionista das relações capitalistas na região. Assim, nos documentos elaborados na comemoração dos cinquenta anos de pensamento do CEPAL (1998:820) destaca-se:

Também não devemos esquecer que a vitória da revolução cubana significou uma mudança radical no estilo de desenvolvimento de um dos países da região. Já em 1961, os Estados Unidos retrucaram, em Punta Del Leste, com um novo projeto de modernização, mediante o qual a região seria mais plenamente incorporada no sistema econômico mundial e no qual o capital estrangeiro desempenharia um novo e decisivo papel.

As profundas reformas estruturais pelas as quais países latinoamericanos passaram na década de 60 tinham no compromisso firmado com os Estados Unidos inscrito na Carta de Punta Del Leste, de $1961^{8}$ e que consistia no financiamento norte-americano do programa "Aliança para o Progresso" por uma década. Os governos beneficiados aceitaram a obrigação de efetivarem reformas estruturais internas para que este financiamento fosse um impulsionador de transformações no âmbito econômico e social. Nesse período, os países se comprometeram a conduzir planos nacionais de desenvolvimento que garantissem o emprego racional dos recursos aos organismos financiadores. Presbisch (1998:38) afirma que na década de 60, verificou-se uma crescente polarização política e ideológica na América Latina com consequências políticas adversas, e acrescenta:

\footnotetext{
8 Presbich (1998) analisa o aporte de recursos internacionais aos países em desenvolvimento na perspectiva da política de cooperação financeira adotada após a 2a Guerra Mundial baseado nos investimentos de capital privado estrangeiro nesses países que obtinham considerável progresso nesses países e acrescenta que na Carta de Punta del Este, estabeleceram-se objetivos quantitativos a serem alcançados nesse aporte de recursos internacionais, e se vincularam o montante e a orientação destes não apenas à viabilidade de projetos específicos, mas também a planos de desenvolvimento em que as transformações da estrutura econômica e social são reconhecidas como exigências inelutáveis do próprio desenvolvimento.
}

[Digite texto] 
Durante toda a década a CEPAL manteria diálogo com as posições políticas moderadas, mesmo à direita do espectro político,bem como com o mundo da diplomacia internacional,em várias áreas: na mobilização da Aliança para o Progresso, no tema da integração regional e da ALALC, na criação da UNCTAD e na multiplicação de assistência técnica em planejamento indicativo a governos na região. A modernização das tecnoburocracias latinoamericanas beneficiou-se muito do trabalho da CEPAL e do ILPES nesse período.

A Carta de Punta del Leste contribuiu para as grandes reformas estruturais nos países latino americanos e julgadas indispensáveis no Brasil à época, para estreitar as relações de cooperação com os Estados Unidos. Tais reformas estruturais foram subsidiadas pelos planos nacionais de desenvolvimento elaborados pelo governo com a contribuição dos intelectuais do IPES- Instituto de Pesquisas e Estudos Sociais e IBAD- Instituto Brasileiro de Ação Democrática no apoio ao regime à época. O governo assumiu o papel de principal responsável pelo desenvolvimento econômico como investidor, regulador e, ainda, protetor do mercado interno e da indústria nacional.

Assim, a participação dos Estados Unidos na elaboração de planos e programas de desenvolvimento econômico nos países latino americanos foi fundamental. Numa concepção hegemônica de que o bem-estar e a prosperidade dos Estados Unidos dependeriam do bem-estar e da prosperidade dos demais países, o programa de ajuda externa norteamericana, em especial a Aliança para o Progresso, simbolizou uma cooperação estratégica de reformas em diversos setores dos governos que se sucederam em busca do desenvolvimento econômico, social e político na América Latina.

O pensamento da CEPAL - Comissão Econômica para a América Latina e - Caribe $^{9}$ dominava as análises sobre os processos de crescimento das

\footnotetext{
${ }^{9}$ A Comissão Econômica para a América Latina foi constituída em 1948, por uma decisão da Assembleia Geral das Nações Unidas de 1947. A criação ocorreu no contexto das queixas latino-americanas de exclusão com relação ao Plano Marshall e de falta de acesso aos "dólares escassos" que dificultava a reposição dos desgastados aparelhos produtivos da região. Os documentos elaborados pelos pensadores cepalinos consistiam no posicionamento crítico e teórico da inserção da região latino-

[Digite texto]
} 
economias latino-americanas e orientava muito as propostas de política econômica nesse período. Segundo as concepções da CEPAL, a industrialização seria o único caminho de desenvolvimento deixado aos países exportadores de produtos primários, no que ficou conhecida por "industrialização substitutiva", com forte intervenção do governo. Ao passo da ampliação dos sistemas de planejamento latino-americanos, o papel da OEA (Organização dos Estados Americanos), do CEPAL e do ILPES (Instituto Latino-Americano e do Caribe de Planejamento Econômico e Social) foram fundamentais no esforço de formar profissionais preparados para apoiar e guiar trabalhos de elaboração dos planos econômicos dos países da região.

As idéias e teorias do ILPES/CEPAL ${ }^{10}$ desenvolvidas nos anos 1950 e 60 fundamentaram a elaboração das políticas de desenvolvimento na América Latina baseadas na inserção desses países na economia mundial via industrialização e expansão das exportações sob a ação do governo a partir do crescimento contínuo e planejado, cujas transformações na estrutura econômica e social seriam reconhecidas como exigências inelutáveis do próprio desenvolvimento. $O$ ideário predominante na época apoiava-se no ordenamento físico-territorial visando melhor desempenho econômico de setores fundamentais da economia.

As relações de cooperação entre o Brasil e os Estados Unidos foram firmadas a fim de afastar as ameaças do comunismo no país e promover reformas em vários setores da economia e da sociedade. O planejamento governamental foi se firmando no país como um dos meios mais eficazes e garantidos de retorno dos investimentos norte-americanos. O planejamento regional ou nacional foi implantado associado ao controle orçamentário a fim de garantir planos e projetos. Desde então a importância de associar plano e projeto ao orçamento plurianual se fez presente como meio de supostamente garantir suas realizações. Assim, Presbisch (1998:414) examina o processo de

americana no processo de industrialização considerando as condições estruturais periféricas e do progresso técnico mundial confinado nos países industrializados.

${ }^{10}$ O ILPES- Instituto Latino Americano e do Caribe de Planejamento Econômico e Social é uma entidade do sistema CEPAL criada nos princípios dos anos $60 \mathrm{com}$ a finalidade de apoiar os governos da região no aperfeiçoamento de estruturas institucionais orientadas com visão de planejamento de longo prazo ao desenvolvimento econômico social e gestão pública, mediante prestação de serviços de capacitação, assessoria e investigação. (www.eclac.org/ilpes/)

[Digite texto] 
financiamento externo dos países em desenvolvimento a fim de garantir investimentos expressos nos planos de desenvolvimento no âmbito de cooperação econômica internacional e acrescenta:

A propósito disso, convém assinalar que a experiência dos planos de desenvolvimento revelou a necessidade de especificar os investimentos necessários para a consecução dos objetivos do plano, os recursos internos que têm que ser mobilizados para esse fim e as contribuições financeiras internacionais que são necessárias para ele. Ainda resta muita coisa por fazer na tarefa de elaborar os métodos e procedimentos apropriados nesse sentido. Um problema particularmente difícil para os países em desenvolvimento é a prática das instituições de crédito internacional de financiar projetos individuais, sem assumir compromissos com o total dos montantes externos necessários durante todo o período de execução do plano. É de esperar que o processo a ser estabelecido para destinar os recursos de financiamento compensatório contribua para que os países em desenvolvimento obtenham todas as garantias razoáveis de que poderão contar com o capital de que necessitam para pôs em prática seus planos de desenvolvimento.

O conjunto das idéias desenvolvidas para a industrialização do Brasil e as influências norte-americanas nas mudanças internas do país influenciaram as concepções e propostas nos planos nacionais de desenvolvimento econômico e social, que expunham uma contradição entre elevar as taxas de crescimento econômico e atenuar as desigualdades inter-regionais. Diante desse impasse, o governo passou a adotar medidas compensatórias objetivando reduzir as disparidades inter-regionais a partir de diversificados investimentos e incentivos, numa perspectiva nacional de se alcançar "equilíbrio" entre regiões.

O ideário do ordenamento territorial sob as influências norte-americanas baseou-se na correção dos desequilíbrios sociais e econômicos entre as regiões segundo a capacidade científica, técnica e administrativa do governo de intervir sobre o espaço e, a partir de uma racionalidade hegemônica, induzir a locação de equipamentos, intervenções e investimentos de forma a distribuílos equilibradamente sobre o espaço. A priori, o ideário de organizar ou ordenar 
o território significava dispor de elementos suficientes sobre o espaço tendo por base as potencialidades dos recursos naturais visando um equilíbrio dos índices sociais, econômicos e demográficos de todo território nacional.

Inicialmente, nessa fase, o ordenamento territorial no Brasil adquiriu uma conotação instrumental do território nacional enquanto base de uma estratégia para se alcançar maior crescimento e desenvolvimento do país. $O$ ordenamento territorial foi considerado inseparável do planejamento econômico geral e normalmente subordinado a este. No entanto, o ordenamento territorial, enquanto função dos governos reuniu concepções científicas e políticas sobre o espaço, o tempo e as decisões coletivas ao passo das grandes transformações das relações capitalistas e das inovações científicotecnológicas. O homem tornou-se um grande protagonista das profundas transformações do espaço numa busca constante do equilíbrio social e econômico entre regiões.

Segundo indicações norte-americanas, seria necessário estender 0 planejamento praticado apenas por engenheiros e arquitetos à administração pública, sobretudo municipal; à Sociologia e Antropologia Aplicada; Economia da Terra Urbana e Desenvolvimento Econômico Regional além da urgente formação de profissionais planejadores. Em muitas universidades latino americanas $^{11}$ foram ministrados cursos em vista de preparar profissionais no campo do planejamento urbano e regional, pela escassez de especialistas nessa área. No caso específico do Brasil, o Ponto IV $^{12}$ e a ONU, em

\footnotetext{
11 Os cursos avançados de Planejamento Regional e Urbano ocorreram na década de 1960 na Universidade do Panamá; Universidade Nacional de Engenharia, no Peru, Universidade do Chile e Universidade Católica do mesmo país; Universidade de Buenos Aires; Universidade de Montevidéu; Universidade de São Paulo, Universidade do Rio Grande do Sul, Universidade de Minas Gerais e Universidade do Brasil. (Francis Violich in Revista Arquitetura)

12 O "Ponto IV" ou Act for International Development incluía-se na política de segurança externa norte americano frente às possíveis investidas dos países comunistas nos países subdesenvolvidos em plena Guerra Fria.. No contexto das acentuadas rivalidades ideológicas entre os EUA e a URSS, foi lançada pelos EUA, a Ideologia Desenvolvimentista, como estratégia da afirmação hegemonia econômica e política dos EUA embasada nos princípios da Doutrina Trumam que visava ajudar financeiramente os países que decidissem lutar contra o comunismo. Os objetivos da política de segurança externa norteamericana foram mediados pela Agência Norte-Americana para o Desenvolvimento Internacional USAID (1958) que ganhou destaque no Brasil a partir de 1961, com a promulgação da "Carta Punta Del Leste". Assim, a reunião do Conselho Interamericano Econômico e Social (CIES-OEA) realizada em Punta Del Leste, Uruguai em 1961 selou o caráter interamericano à Aliança para o Progresso, proposta pelo governo John Kennedy pelas Repúblicas Americanas.
}

[Digite texto] 
colaboração com as autoridades brasileiras levaram às primeiras medidas para o ensino do planejamento regional e urbano nas universidades.

No contexto de expansão das empresas no mundo capitalista em pleno período da Guerra-Fria, o planejamento regional esteve relacionado à maior inserção das regiões menos desenvolvidas no contexto econômico do país, na redução dos desequilíbrios inter-regionais e na integração do território nacional. O ideário de equilíbrio entre regiões e igualdade de acesso aos bens e equipamentos públicos pela população a partir de uma melhor distribuição da população pelo território e a sua respectiva integração a fim de reduzir a pressão demográfica nas metrópoles foram legitimados por acordos internacionais, pela própria Constituição Federal de 1967, decretos-lei, planos governamentais, leis e normas, assim como pela criação de órgãos e políticas públicas elaboradas nas estruturas do governo.

Como dito anteriormente, o planejamento do ordenamento territorial esteve voltado para as regiões consideradas de menor desenvolvimento como a Amazônia e o Nordeste objetivando a integração do território e o desenvolvimento nacional. Alguns órgãos foram criados como o Banco do Nordeste, SPVEA (Superintendência de Valorização Econômica da Amazônia), SPVESUD (Superintendência do Plano de Valorização da Fronteira Sudoeste do País), SUDENE (Superintendência de Desenvolvimento do Nordeste), SUDAM (Superintendência de Desenvolvimento da Amazônia), SUDECO (Superintendência de Desenvolvimento do Centro-Oeste), SUDESUL (Superintendência de Desenvolvimento do Sul) e, numa perspectiva de planejamento integrado direcionado ao Sudeste, detentor das principais metrópoles nacionais, tivemos a SERSE (Secretaria Especial da Região Sudeste). Tais órgãos vieram a somar-se à CIBPU (Comissão Interestadual da Bacia Paraná-Uruguai) e à CVSF (Comissão do Vale de São Francisco), já existentes e centradas no desenvolvimento de bacias hidrográficas inspiradas no modelo de planejamento norte-americano do vale do rio Tennessee ${ }^{13}$.

\footnotetext{
${ }^{13}$ Destacamos a experiência do Vale do Rio Tennessee ou TVA- Tennessee Valley Authority como uma das mais bem sucedidas e considerada de fundamental valor em termo de apredizagem de coordenação e administração que envolveu vários Estados e seus respectivos territórios numa tentativa moderna de planejamento regional, iniciada em 1930 nos EUA em plena crise econômica e social no governo de Roosevelt iniciada com a quebra da Bolsa de Nova York em 1929.
}

[Digite texto] 
Nas décadas de 1950 e 1960, o governo assumiu o hegemônico papel de agente político e econômico, apto a conduzir projetos de desenvolvimento que a princípio seriam capazes de superar as desigualdades espaciais. As teorias sobre o desenvolvimento se destacavam e as políticas públicas compensatórias de base keynesiana seriam consideradas capazes de fazer frente às fases recessivas dos ciclos econômicos e de reduzir as disparidades sociais e setoriais inter-regionais.

Após um longo período de elevado crescimento econômico no Brasil, a crise que abalou as economias dos países centrais culminou, em 1964, com a tomada do governo pelos militares e a instalação de regime altamente repressor dos direitos civis e sociais fundamentais da sociedade. Ao longo da ditadura militar, o discurso predominante apoiava-se no ideário modernizador e comprometido com a retomada do crescimento econômico. O quadro de elevada inflação e a necessidade de retomar as relações com os organismos internacionais de financiamento justificavam a adoção de políticas econômicas concentradoras de recursos pelo governo federal.

O período dos militares na direção do país correspondeu ao auge do planejamento governamental. Os primeiros planos de abrangência nacional e regional elaborados ao longo desse período estiveram voltados para o controle das taxas inflacionárias, para a redução do déficit habitacional e de transportes, e para a retomada da capacidade das indústrias instaladas, mas de restrito alcance nas mudanças na concepção do ordenamento territorial do país. As políticas de ordenamento direcionadas a redução das disparidades regionais se restringiram à criação de órgãos governamentais destinados ao desenvolvimento das regiões consideradas menos desenvolvidas, transparecendo uma grande política de distribuição de recursos de cunho compensatório.

As questões urbana e regional incluíam-se numa perspectiva nacional, uma vez que o projeto dos governos militares era transformar o país em uma grande potência até o final do século XX. Às regiões metropolitanas foram direcionadas políticas de descentralização, principalmente o eixo entre Rio de Janeiro e São Paulo, com a intenção de controlar o processo de urbanização concentrada espacialmente nessas grandes cidades, sobretudo em reduzir a pressão sobre o solo urbano e de reduzir o atraso de outras regiões do país [Digite texto] 
oriundo, segundo discurso do governo, de uma economia excessivamente desequilibrada territorialmente.

Até então, o ordenamento territorial baseado na geopolítica e na doutrina da Segurança Nacional, a partir do planejamento racionalista do governo para intervir nas regiões metropolitanas a fim de obter maior controle de seu crescimento e dos fluxos migratórios, passou a sofrer influências de inspiração francesa no planejamento territorial, pautadas no aménagement du territoire francês, assim como as propostas relativas aos pólos de crescimento como resposta aos desequilíbrios setoriais e espaciais que serviram de base às propostas de regionalização do território nacional, em complementação às divisões regionais oficiais do governo e as estratégias de desenvolvimento.

Muitos estudos denominados regionais desenvolvidos na época enfatizavam os princípios científicos que contribuíam para a delimitação das regiões, que na maioria das vezes não condiziam com as definições das unidades territoriais ou administrativas do governo e na maioria das vezes não davam o suporte para o necessário planejamento regional. A realidade das cidades em expansão impunha uma nova concepção do planejamento urbano e regional; principalmente quanto ao urbanismo que se propunha ordenar os assentamentos humanos sobre o espaço, seja urbano ou rural, da melhor forma possível, inspirando-se, como já citado, no chamado aménagement du territoire. Nesse período, a Geografia e o geógrafo muita das vezes foram apontados indispensáveis ao ordenamento territorial urbano.

Ao longo desse período, alguns pontos foram levantados de modo a atentar para os desafios lançados ao Brasil e para a necessidade de um aporte maior ao ordenamento territorial no planejamento governamental. A Carta do Brasil ao Milionésimo ${ }^{14}$ como parte integrante da Carta Internacional ao

\footnotetext{
14 A Carta do Brasil ao Milionésimo faz parte de um plano mundial originário da convenção internacional realizada em Londres em novembro de 1909. O Brasil como membro da ONU assumiu o compromisso de produzir a carta do seu âmbito territorial. A Comissão Organizadora da Carta ao Brasil do Clube de Engenharia editou pela primeira vez, em 1922, comemorando o centenário da Independência. .Pelo decreto-lei No 237 de 1938 ficou atribuído ao IBGE - CNG Conselho Nacional de Geografia a execução das folhas da Carta do Brasil ao Milionésimo que em 1945 elaborou uma revisão que passou a ser revista decenalmente até os anos 90 quando foram observadas discrepâncias em relação aos valores anteriormente divulgados para as superfícies estaduais e municipais. A evolução tecnológica implementada nos últimos anos no IBGE vem proporcionando maiores ajustes nos dados das extensões territoriais do país, dos estados e municípios.
} 
Milionésimo ${ }^{15}$ assumiria relevante papel no planejamento do desenvolvimento
econômico com base nas necessidades nacionais. Barbosa (1960:20) reafirma
o papel do mapeamento no ordenamento territorial seguindo as obrigações
internacionais na elaboração e manutenção atualizada da carta ao milionésimo:

Todo planejamento do desenvolvimento econômico, nacional, ou regional, exige dos seus primeiros planos ao controle de sua execução, o mapa. O represamento das águas fluviais para a produção de energia elétrica, o planejamento das redes de irrigação, a instalação de linhas de energia para servir a localidades e centros industriais, tendo em vista sua posição na região e distribuição de sua produção, não prescindem da carta.

Barbosa (1960:84) ainda acrescenta em que a elaboração da carta pressupõe a instalação de uma entidade organizada em moldes permanentes, com aparelhagem e equipe de técnicos especializados no ramo de compilação de mapas geográficos gerais, que acumule experiências. O tempo de existência da instituição também desempenha, neste campo, papel de grande importância, não só no que diz respeito ao material, todo ele de preço elevado, exigindo em consequência, vultoso emprego de verbas e que só pode ser adquirido a longo prazo, como também no que se refere ao pessoal técnico

\footnotetext{
${ }^{15}$ A Conferência Técnica Internacional sobre a Carta Internacional ao Milionésimo - O primeiro intento coordenado para a elaboração de um mapa do mundo na escala ao milionésimo ocorreu no Congresso Geográfico Internacional realizada em Berna, no ano de 1891. Posteriormente em 1908, na IX Conferência Internacional de Geografia em Genebra, foi concretizado mais um passo nesse sentido, quando a delegação norte-americana propôs a aceitação por todos os países de um único sistema para esse tipo de representação. Em 1909, na I Conferência Internacional sobre a Carta ao Milionésimo em Londres, foi debatida aquela proposição de forma objetiva. Depois em Paris em 1913 e depois não foi mais possível fazer novas reuniões devido ao surto da 1 a Guerra Mundial. Reconhecimento a importância da confecção da Carta Internacional ao Milionésimo, especialmente para o desenvolvimento econômico, a ONU retomou as reuniões em Mussourie, Índia em 1955, Tóquio em 1958 e Bangueloque em 1961, e providenciou a partir do Conselho Econômico e Social uma reunião dos Estados membros, na qual foi tratado, no item de sua agenda, "Cooperação Cartográfica Internacional" em conexão com a Organização Internacional da Aviação Civil (ICAO), o assunto em abril de 1956 e posteriormente na reunião de Tóquio em 1958, debateu e deliberou sobre temário idêntico, fixando-se em ambas, o inevitável valor de manter em constantes reedições atualizadas a carta, a par do intercâmbio de informações, normas técnicas e padronização das normas geográficas. Essas reuniões definiram pontos essenciais para a elaboração da Carta Internacional ao Milionésimo considerando a mesma como um pré-investimento destinado ao estudo do desenvolvimento econômico de planificação que serve às necessidades dos diversos especialistas de muitas ciências; e é a base para a elaboração de todos os mapas no que se refere à vegetação, à população, ao solo, à geologia, à administração, às avaliações estatísticas, aos recursos minerais, etc.
}

[Digite texto] 
que, mesmo bem selecionado dentre os de melhores conhecimentos teóricos, não pode prescindir da experiência capaz de prepará-lo convenientemente para o exercício de sua especialidade.

Assim, muitos indicativos apontavam para a necessidade de maior conhecimento da realidade como princípio para se ordenar o território nacional. As influências francesas no ordenamento territorial no Brasil nas décadas de 1950 e 1960 estiveram presentes nos estudos de centros de polarização, pólos de desenvolvimento, regiões homogêneas, regiões polarizadas, que buscavam integrar o planejamento local ao sistema de planejamento nacional e integrar planos diretores de cidades em planos regionais. Enfim, estudos que exigiam o conhecimento do território e dos processos de regionalização, contaram com o desempenho do CNG (Conselho Nacional de Geografia do IBGE (Instituto Brasileiro de Geografia e Estatísticas) e do EPEA (Escritório de Pesquisas Econômicas Aplicadas, atualmente IPEA - Instituto de Pesquisa Econômica Aplicada); destaque-se, nesse período, a adaptação do estudo à realidade brasileira com a contribuição metodológica dos professores Rochefort e Hautreaux ${ }^{16}$ à época para fins de planejamento. Assim, acrescenta-se:

A definição dos tipos de polo e a escolha dos polos propriamente ditos é matéria de interesse geral, dela devendo participar todos os organismos regionais e estaduais de planejamento e de financiamento.

(Revista Brasileira de Geografia, ano 1967 v.1)

A percepção da realidade metropolitana no país aos poucos instigava aprofundamentos científicos que ultrapassavam os incipientes estudos de Pierre Deffontaines e de Pierre Monbeig na década de 1940, que abordavam

\footnotetext{
${ }^{16}$ O Prof. M. Rochefort propôs, em 1956, uma classificação de tipos de cidades, em que se consideram as funções e a hierarquia dos aglomerados urbanos. Estabelece-se, de início, a centralidade de uma cidade dentro de um conjunto, o que implica nas funções de relação das localidades. As de tipo A seriam os centros locais; de tipo $B$, os de sub-região; de tipo $C$, os regionais; de tipo $D$, as metrópoles de grandes regiões e de tipo $E$, as metrópoles nacionais. Em 1966, Rochefort adaptou às condições brasileiras a metodologia aplicada na definição de regiões homogêneas e polarizadas na França e Espanha, impunha investimentos no levantamento de dados e informações do território brasileiro a fim de fornecer uma visão integrada básica das potencialidades das diferentes áreas do país, tendo em vista a maximização do seu desenvolvimento econômico no que ficou conhecido por método RochefortHautreaux.
} 
estudos isolados relacionados ao ordenamento interno de cidades e novos estudos surgiram, relacionados aos centros urbanos com sua área de influência. Outros estudos focalizavam a posição e o sítio, a evolução urbana, a estrutura e as funções da cidade. Ao passo do desenvolvimento de estudos que permitiram maior conhecimento do território nacional, o estudo da cidade na perspectiva regional ia se desenvolvendo; no que ficou chamado, de redes urbanas na década de 1960, sob a influência da escola francesa de geografia, tendo sido notável a contribuição dos professores Michel Rochefort e Jean Tricart $^{17}$.

Diante da realidade metropolitana do país, estudos relacionados às redes urbanas, sob influências estrangeiras, apontavam para uma dinâmica específica dessas regiões e principalmente para o controle desses espaços. Trabalhos pioneiros de ordenamento territorial urbano atentavam para as regiões metropolitanas para fins de planejamento e de inserção no contexto mais amplo de desenvolvimento desde os anos de 1950, como o de J. Lebret com as experiências da SAGMACS (Sociedade para a Análise Gráfica e Mecanográfica Aplicada aos Complexos Sociais) no Brasil. Os trabalhos de "Economia e Humanismo" indicavam uma mudança na concepção do planejamento regional e urbano que se afastaria das influências da arquitetura e adquiriria aspectos de estudos estritamente urbanos, considerando uma estrutura sócio-econômica relacionada com os padrões de distribuição físicoespacial.

Lobato Corrêa (1967: 99) no artigo em que analisa o estudo da cidade num conjunto regional sobre as redes urbanas comenta que em seu estudo sobre "Necessidades e Possibilidades do Estado de são Paulo" realizado sob a orientação e participação de J. Lebret, a SAGMACS (63: 180-192) dedica um capítulo sobre a divisão do estado em regiões "unidades de organização e

\footnotetext{
${ }^{17}$ O Congresso Internacional de Geografia serviria de oportunidade para novos contatos com a escola francesa de geografia através de Michel Rochefort e Jean Tricart, vindo com eles, de modo especial com o primeiro, as ideias e métodos de trabalho sobre redes urbanas, tema que na França, àquela época já havia despertado interesse por parte dos geógrafos. Paralelamente, havia melhor conhecimento de algumas áreas do país, que serviriam de quadro para os estudos sobre a vida de relações. No entanto, apesar dessa nova orientação e do interesse despertado entre diversos geógrafos brasileiros, em nenhuma das comunicações apresentadas no Simpósio sobre o "Habitat Urbano", em 1959, incluía estudos sobre redes urbanas, apesar de entre os temas constar um dedicado ao estudo das metrópoles e sua vida de relações regionais. (Revista Brasileira de Geografia, ano 1967 v. 4).
}

[Digite texto] 
aproveitamento". São definidas preliminar e teoricamente as unidades territoriais que podem desempenhar através de uma cidade um papel de intermediária entre o Estado e os municípios, ou seja: as zonas homogêneas, onde "os problemas a serem resolvidos são os mesmos", e a região, isto é, "a unidade territorial que compreende certo número de localidades com ligações regulares com um centro melhor equipado em serviços de todas as espécies". Foram levados em consideração que o número de regiões a terem existência legal não deveria ser muito numeroso, que deveriam levar em consideração àquelas regiões "que a vida se encarregou de criar e delinear", bem como não haveria necessidade de escolher-se como "centro de região a cidade atualmente mais importante, mas aquela que mais facilmente pudesse ser atingida por toda a região, contanto que estivesse já suficientemente equipamento de saúde e se possível de escolas superiores".

Essas e outras influências estrangeiras no ideário do ordenamento territorial urbano estiveram presentes até finais dos anos 80, quando novos questionamentos iam sendo elaborados quanto ao modelo de planejamento mais adequado à realidade dos novos arranjos territoriais que surgiam e a própria complexidade das relações sociais que se estabeleciam com base nos avanços científicos e tecnológicos, numa economia cada vez mais internacionalizada. Apesar das mudanças aceleradas que passaram a ocorrer no âmbito econômico, político, social e cultural, as grandes desigualdades sociais e econômicas se acentuavam, impondo reformas no planejamento urbano e regional.

No entanto, apesar da crise que se abateu nos anos 80 e que abalou as estruturas de governo de muitos países latino-americanos, fazendo ruir as estruturas de planejamento desses países, novas políticas intervencionistas do espaço urbano, sob outro ideário, foram introduzidas nesses países a fim de redinamizar suas economias abstendo-se de uma percepção regional do desenvolvimento territorial; mas a importância do planejamento integrado no ordenamento territorial urbano nunca deixou de existir como uma resposta aos graves problemas urbanos.

No capítulo que se segue, pretende-se reconhecer as influências estrangeiras que influenciaram o ordenamento territorial no Brasil e que se superpõem de modo conflituoso, segundo a ausência de um projeto integrador 
de seus ideários. Atenta-se à ausência de um modelo integrador de desenvolvimento territorial, pelo desmonte de toda a estrutura de planejamento do desenvolvimento territorial e, o domínio das políticas intervencionistas urbanas isentas da perspectiva regional do ordenamento territorial. Dessa forma, torna-se importante criar parâmetros quanto à realidade do país, em termos do que podemos considerar como avanços institucionais quanto ao ordenamento territorial, como no caso da França. 


\subsection{Capítulo 3_- A institucionalização do planejamento do ordenamento territorial: reflexões comparativas entre França e Brasil}

De modo a criarmos alguns parâmetros que nos auxiliem em nossa análise, destacamos alguns exemplos de países que tiveram experiências de planejamento regional a fim de reduzirem as disparidades regionais e assumirem questões relacionadas ao ordenamento de seus territórios com base no desempenho de políticas de desenvolvimento territorial dos correspondentes níveis de governo. Percebemos, no entanto, a estreita relação do processo de democratização e descentralização das políticas e os necessários avanços institucionais, sociais e de infraestrutura com base nos atuais parâmetros do ordenamento territorial.

A forma de governo de alguns países da atual União Européia, por exemplo, destacava-se pelo intervencionismo do governo central no ordenamento territorial e após mudanças geopolíticas, com a unificação européia, a política regional dos países-membros contou com a descentralização do poder entre os níveis do governo e com a autonomia administrativa de suas instâncias. Destaca-se a criação de instituições com uma forte dose de descentralização, de efetiva representação política dos interesses das comunidades locais e de efetiva autonomia na gestão de seus interesses e finanças como na França, na Alemanha, na Áustria e na Bélgica; assim como em Portugal, na Espanha, na Itália e no Reino Unido e nos países escandinavos, entre outros.

Valendo-se de específicas peculiaridades entre os países europeus capitalistas ocidentais citados acima, de modo geral, o planejamento regional direcionado a atenuar as disparidades regionais desses países implantou-se concomitante ao processo de democratização e de descentralização do poder entre os níveis de governo. Embora considerado um grande desafio, avanços institucionais corroboraram a autonomia administrativa dessas instâncias no ordenamento de seus respectivos territórios e fez valer de fato os princípios do federalismo de interdependência cooperativa entre os entes federativos com o objetivo de equilíbrio e controle. 
De modo a se contraporem ao regime centralizador dos governos, 0 planejamento regional que se implantou nesses países, na maioria dos casos, contou com a criação de autoridades metropolitanas a fim de identificar problemas e propor soluções administrativas no contexto de descentralização das políticas nas grandes metrópoles.

No caso da França, o termo aménagement du territoire surgiu com a Lei Cornudet de $1919^{18}$, mas com registro de muitas experiências anteriores, principalmente relacionadas ao urbanismo. Nos anos de 1940, foi quando experiências do aménagement $d u$ territoire à escala nacional se efetivaram. País territorialmente extenso e de acentuadas disparidades regionais, deu inicio à implementação de seu sistema de planejamento após a Segunda Guerra Mundial, com a criação do Comissariado Geral do Plano, em 1946 e a introdução dos planos nacionais. E na perspectiva do planejamento regional, após a publicação em 1947, do livro "Paris e o Deserto Francês" de autoria de Jean-François Gravier apud Monod e Castelbajac (2010:25), alertou-se para o desequilíbrio territorial entre Paris, de elevada concentração industrial e demográfica, e as demais regiões. O autor apontava o modelo de crescimento econômico como uma das causas principais dos desequilíbrios regionais e a necessidade do planejamento regional para redução desses desequilíbrios.

Alguns elementos foram fundamentais para que a França desse início a uma das mais ricas experiências de planejamento regional e ordenamento territorial, com os desequilíbrios territoriais e suas tendências, a consciência social e política do problema e o esforço de reconstrução nacional. Desde o final da década de 1940 o ordenamento territorial foi avançando institucionalmente com a criação da Direção de Ordenamento do Território, no Ministério da Reconstrução e do Urbanismo, da proposta de um Plano Nacional de Ordenamento do Território e da criação do Fundo Nacional de Distribuição Territorial.

Na década de 1950, a França foi dividida em macrorregiões e foram estabelecidos programas de ação regional que visavam maior funcionalidade

\footnotetext{
${ }^{18}$ A lei Cornudet de 1919 foi a primeira lei francesa sobre desenvolvimento, embelezamento e extensão das cidades. Inseria-se no contexto da necessidade de encarar transformações em Paris após a primeira Guerra Mundial que teriam de acelerar, sobretudo a ocupação de zonas de espaços livres e zonas de crescimento da cidade junto com as reconstruções em concordância com a legislação em vigor.
}

[Digite texto] 
territorial e maior bem-estar da população. Foram criados o Fundo de Desenvolvimento Econômico e Social (FDES), o Comitê Interministerial de Ordenamento do Território (CIAT) e o Comitê de Descentralização, prevendose, também, a criação de sociedades de desenvolvimento nas regiões. Os sistemas de planejamento e de planejamento territorial se basearam nos princípios da redistribuição, criação, recuperação, proteção e compensação que foram ao longo dos anos adaptados e instrumentalizados de modo a atribuir-lhes caráter permanente.

Na década de 1960, a implementação das políticas regionais e as novas interpretações sobre o problema e os avanços teóricos levaram à criação da DATAR- Delegação para o Ordenamento do Território e da Ação Regional, em $1963^{19}$, que passou a coordenar toda a política regional e de ordenamento do território, além da criação do Fundo de Intervenção para o Ordenamento do Território (FIAT). O objetivo principal foi combinar políticas de desconcentração industrial com a implementação de pólos de crescimento e uma enfática política urbana de criação de novas centralidades, com destaque para as metrópoles de equilíbrio e de novas cidades em torno de Paris. As metrópoles de equilíbrio visavam uma melhor ordenação macro-espacial do território francês e as novas cidades em torno de Paris visavam criar um anel de proteção que impedisse o crescimento da capital.

O considerável sucesso do planejamento regional e do ordenamento territorial baseado nas metrópoles de equilíbrio e nas novas cidades, tanto em Paris como em outras localidades, foi interrompido pelas manifestações da sociedade em $1968^{20}$, baseadas nas disparidades inter-regionais não solucionadas e pela própria crise mundial do petróleo e da crise mundial que se

\footnotetext{
19 A DATAR foi criada em 1963, rebatizada em 2005 como DIACT- Delegação Interministerial ao Ordenamento e a Competitividade dos Territórios que retornou a DATAR em 2009. Trata-se de um Estado maior de muitos encargos e missões que intervém nos comitês interministeriais junto à presidência do Primeiro Ministro para proceder as impulsões e as arbitragens necessárias. Na França, a DATAR como órgão supra-ministerial de ordenamento territorial possui orçamento próprio e as políticas de ordenamento territorial estão em segundo lugar, atrás das políticas agrícolas.

20 - A França dos anos de 1960, sob o comando do general Charles De Gaulle, era uma sociedade culturalmente conservadora e fechada, vivendo ainda o reflexo das perdas sofridas durante a 2a Guerra Mundial. Tornou-se ponto de partida para uma série de transformações políticas, éticas, sexuais e comportamentais que afetaram a sociedade da época de uma maneira irreversível. Foi o marco para movimentos ecologistas, feministas, das ONG's e dos defensores das minorias e dos direitos humanos e para mudanças institucionais e de regimes.
}

[Digite texto] 
seguiu; e que abalou tanto a economia quanto a política regional francesa. Tal fato levou a criação do FEDER- Fundo Europeu de Desenvolvimento Regional, pela Comunidade Européia, na política regional, afetando a autonomia dos países integrantes na implementação de suas políticas regionais.

Nos meados de 1970, em plena crise econômica após um período de elevado crescimento e desenvolvimento e uma crise política com a estagnação do papel intervencionista do governo central, foi aprovada a LOADDT- Lei de Orientação para o Ordenamento e Desenvolvimento Durável do Território ${ }^{21}$ após intensa pressão política das pequenas comunas, como proposta de reordenar o território a partir de maior integração entre os espaços rurais e urbanos e da ação efetiva das coletividades locais, dando início ao processo de descentralização.

Durante longos anos de governos centralizadores, de rígida administração, e de grandes desequilíbrios regionais, a França foi alvo de grandes reformas no intuito de promover não apenas a desconcentração administrativa, mas a descentralização seguida de maior autonomia administrativa dos níveis de governo. Nos anos de 1980, no governo de Mitterrand, muitas medidas foram tomadas no sentido da descentralização política entre os níveis de governo e da relevância deles no planejamento no contexto das mudanças das relações globalizadas.

Para o ordenamento territorial, o processo de descentralização na França foi de fato institucionalizado com a Lei de 1982 - Lei Defferre ou lei da descentralização relativa aos direitos e liberdades das comunas, dos departamentos e das regiões, constituindo o início do processo de implementação de uma estrutura regional ligada ao desenvolvimento do ordenamento territorial. A referida lei de 1982 instaura eleição do conselho regional ao sufrágio universal, transfere o poder executivo ao presidente e estabelece que o conselho regional crie regras sobre os assuntos de sua região a partir de suas deliberações. Essa lei abriu o caminho para uma

\footnotetext{
${ }^{21}$ Após inúmeras adaptações da LOADT que se tornou LOADDT incluindo aspectos de sustentabilidade do desenvolvimento nos anos de 1990, a referida lei indica que a política de ordenamento do território está baseada na redução de desigualdades e desequilíbrio entre territórios relacionados aos aspectos geográficos, ao conjunto do território, ao acesso aos serviços públicos em termos de distância. Segundo a lei, o equilíbrio está na repartição equilibrada dos equipamentos sobre o território ordenado.
}

[Digite texto] 
profunda transformação da repartição de poderes segundo os atores políticos locais.

O processo de descentralização na França como um dos princípios básicos para o ordenamento territorial tem por base reformas que enfatizam a autonomia das comunas, dos departamentos e das regiões. Após a lei de 1982 que constituiu um dos maiores abalos institucionais na França, as coletividades territoriais, em especial as comunas, adquiriram de fato autonomia a ponto de se sobreporem aos interesses dos políticos, das normas, de tributar recursos, de elaborarem seus planos de urbanismo fixando as condições de ocupação do solo ou em outras palavras de ordenarem seu próprio território. E as regiões reafirmaram a preocupação de fazer coincidir a geografia política e administrativa com a geografia econômica e definir as zonas de influências das grandes cidades, embora se tratasse de um assunto susceptível às discussões por considerar variáveis históricas, sociais, culturais, políticas e econômicas que envolvem muitos interesses das denominadas coletividades locais.

Segundo Monod e Castelbajac (2010: 35-36) a Lei Defferre pode ser considerada como uma das mais impactantes leis do quadro institucional da França pois designa total autonomia às comunas a partir do poder de tributar elas mesmas e construir suas reservas de recursos assim como estabelecer seus planos de urbanismo fixando as condições de ocupação do solo e de ordenar seu próprio território. De modo a superar dificuldades, o governo incentiva a criação de associações de comunas envoltas em um projeto comum de desenvolvimento na perspectiva do ordenamento territorial. E acrescenta que a reforma contida na Lei Defferre cria uma importante instância entre o governo e as comunas: as regiões na perspectiva do ordenamento territorial

La seconde reforme est La création d'une entité nouvelle, lês régions. $\mathrm{Si}$, comme l'a écrit Tocqueville, c'est dans La commune, au coeur dês relations ordinaires de la vie, que reside la force dês peuples libres et que viennent se concentrer "le besoin d'intérêts réels, le goût Du povoir, le désir de l'estime", l'aménagement exigeait um échelon intermédiaire entre la commune et l'État, ou pourraient s'opérer lês arbitrages nécessaires. ${ }^{22}$

\footnotetext{
${ }^{22}$ A segunda reforma é a criação de uma entidade nova, as regiões. Assim como Tocqueville escreveu, é nas comunas, ao centro das relações ordinárias da vida, que reside a força dos povos livres e que vem se [Digite texto]
} 
No entanto, apesar da institucionalização das coletividades territoriais na França e da descentralização que impôs severas transformações na arquitetura de poderes no ordenamento territorial, a legislação não acompanha a dinâmica dessas transformações e decorre espacialmente a sobreposição das competências das coletividades territoriais e das competências do governo central.

Quanto ao discurso de equilíbrio territorial, as diferenças dos níveis de recursos das coletividades territoriais se reafirmam territorialmente entre coletividades territoriais com maiores recursos arrecadáveis, que se tornam mais atraentes aos investidores, e as de menores recursos que, para equilibrar seus orçamentos são obrigadas a adotar políticas de controle de despesas e forte pressão fiscal, condições pouco atraentes aos investidores. As disparidades inter-regionais permanecem em todo o território nacional e os conflitos de interesses políticos entre os diferentes grupos da sociedade.

A partir dos anos de 1990, fatores como a consolidação da unificação européia no contexto de elevada competitividade mundial, a abertura econômica, as transformações tecnológicas e a instantaneidade de informações disponíveis desafiam o governo em estabelecer uma política regional em novos moldes e que coadune referenciais de sustentabilidade em termos ambientais, econômicos e sociais sobre o território nacional diverso e com grandes disparidades regionais.

A partir da realidade relatada, dos avanços e desafios no ordenamento territorial urbano na França, consideramos que o período da ditadura militar no Brasil foi de máxima importância para a caracterização da política de ordenamento territorial nacional, que combinou fatores favoráveis como o elevado crescimento econômico do país, mecanismos centralizadores de poderes e recursos pelo governo federal e as influências intervencionistas orientadas pelas políticas keynesianas. O sistema de planejamento regional implementado tinha em vista atenuar as grandes disparidades regionais que se tornavam grandes obstáculos à expansão das relações capitalistas no mundo. 
O ideário de integração do território nacional baseado nas macrorregiões estabelecidas pelo IBGE, aos poucos foi sendo sobreposto pelo ideário do planejamento direcionado para as estruturas regionais do país. O planejamento nacional por si só não resolvia as grandes disparidades inter-regionais que se acentuavam ao longo dos anos. Deste modo, o planejamento do desenvolvimento territorial do país dependeria de maiores estudos das estruturas regionais, como já se observava em outros países capitalistas considerados desenvolvidos, como a França. Muitos estudos foram elaborados a fim de identificar áreas mais desenvolvidas e o seu potencial de polarização de fluxos sobre o território e áreas menos desenvolvidas a fim de elaborar políticas que favoreceriam a atração de indústrias para estas áreas.

Embora os estudos demonstrassem novas regionalizações do território brasileiro, a distribuição do poder entre os níveis do governo, segundo a Constituição Federal de 1967, dificultava o planejamento do desenvolvimento regional no país. A institucionalização do planejamento urbano e regional manteve-se de forma muito concentrada na esfera federal. E o que forçosamente denominamos de planejamento regional, não passou de uma política ditada pelo governo federal baseada nos desníveis das regiões menos desenvolvidas para canalizar recursos e favorecê-las com incentivos fiscais para atrair empreendimentos econômicos.

O planejamento regional no Brasil estruturou-se num cenário de dualidades entre os estudos regionais elaborados, que apontavam verdadeira incompatibilidade do planejamento regional com os limites territoriaisadministrativos. Por outro lado, as regiões metropolitanas, mesmo que reconhecidas pelo art. 164 da Emenda Constitucional de $1969^{23}$, não se constituíram em unidades de teor jurídico ou político. Como as mais importantes metrópoles regionais, coincidentemente correspondem às capitais estaduais, os limites de suas regiões se aproximariam aos limites dos respectivos Estados, houve a tentativa de delegar aos Estados, a responsabilidade pelas unidades de planejamento metropolitano com a criação

\footnotetext{
${ }^{23}$ A União mediante lei complementar poderá para a realização de serviços comuns, estabelecer regiões metropolitanas, constituídas por municípios que independente de sua vinculação administrativa, façam parte da mesma comunidade sócio-econômica.
}

[Digite texto] 
de órgãos de planejamento nessa esfera do governo, inseridos no contexto de domínio do governo federal.

As políticas de integração do território nacional iniciadas desde a década de 50, contaram com a tentativa de implementar um sistema de planejamento após a tomada do governo pelos militares em 1964; e da criação do cargo de Ministro Extraordinário para a Coordenação dos Organismos Regionais. De fato, a partir de 1967, com a promulgação do Decreto-Lei 200 e das inovações no âmbito da administração pública, criou-se na esfera federal o Ministério do Planejamento e Coordenação Geral, conferindo caráter permanente ao órgão central de planejamento, até então representado pelo cargo de Ministro Extraordinário de Planejamento e Coordenação Econômica.

Nessa época de institucionalização do planejamento no país, o ideário do ordenamento territorial foi destinado ao Ministério do Interior, criado pelo Decreto-Lei No 200 de 1967, e a órgãos e entidades que tinham por objetivo reduzir as disparidades inter-regionais buscando maior equilíbrio na ocupação do território a partir de programas e projetos de controle das migrações internas para os grandes centros e da implementação de infraestrutura local visando o bem-estar da população.

Ao Setor de Planejamento do Ministério do Planejamento e Coordenação Geral destinava-se a elaboração dos Planos Nacionais de Desenvolvimento, que de modo geral propalavam estratégias de equilíbrio regional a partir das intervenções do governo sobre o território. Os desequilíbrios regionais do país estariam associados à ausência de planejamento em ampla escala sobre o território nacional, a fim de descentralizar as decisões pelo governo, e ao processo de industrialização para fazer valer os princípios do federalismo e da soberania nacional. A efetiva presença intervencionista do governo federal redistribuindo equipamentos sobre o território nacional, sob coordenação setorial, garantiria maiores investimentos produtivos nas regiões consideradas menos desenvolvidas do país a fim de transformá-lo numa nação desenvolvida. O maior nível de desenvolvimento econômico da região sudeste serviria de parâmetro ao discurso dos desequilíbrios regionais e a concentração demográfica nos grandes centros deveria ser controlada. 
O processo de conscientização da necessidade de planejar o crescimento das cidades teve seu estopim em 1963 com o SHrU- Seminário de Habitação e Reforma Urbana ${ }^{24}$, que propunha a criação de uma Superintendência de Urbanização, em nível federal, a fim de elevar a conscientização dos problemas urbanos no país. Sendo assim, após a mudança de regime de governo em 1964, alguns avanços institucionais ocorreram na esfera federal, deixando a desejar maiores desdobramentos do Sistema de Planejamento aos demais níveis de governo: Estados e municípios.

Durante o período da ditadura militar, a conscientização da necessidade de planejar o crescimento dos centros urbanos foi se institucionalizando com a criação em 1964 do BNH - Banco Nacional da Habitação e do SERFHAU Serviço Federal de Habitação e de Urbanismo, integrados ao Ministério do Interior, marco do planejamento público de cunho descentralizador da administração pública e de expansão da administração indireta; e da criação do Setor de Planejamento Regional e Municipal no Ministério do Planejamento e Coordenação Geral em 1965; do FINEP- Fundo de Financiamento de Estudos, de Projetos e Programas e do FIPLAN- Fundo de Financiamento de Planos de Desenvolvimento Local Integrado, pelo Ministério do Planejamento e Coordenação Geral, para a elaboração de planos e projetos urbanos.

Em 1969, com o objetivo de concentrar esforços em ações locais, o MINTER instituiu o PAC-Programa de Ação Concentrada, que selecionou municípios, e que tinha como atribuição prestar assistência técnica e colaborar com os governos estaduais e municipais, visando ao interesse maior do planejamento em nível federal. O ordenamento territorial, denominação pouco utilizada nesse período e incompatível ao momento político que o país

\footnotetext{
${ }^{24}$ O "s.HRu- Seminário de Habitação e Reforma Urbana", "O Homem, sua Casa, sua Cidade" , organizado pelo IAB- Instituto de Arquitetos do Brasil em conjunto com o IPASE ocorreu no Hotel Quitandinha em Petrópolis em 1963 inserido no contexto de discussão das reformas de base baseadas nas péssimas condições de moradia em que vive a maioria dos brasileiros e da desordem que impera na quase totalidade dos nossos núcleos urbanos. A ausência de entrosamento entre o planejamento econômico que estabelece a ordem dos grandes investimentos governamentais e o planejamento físico (inexistente até então) capaz de dar as condições de um ótimo rendimento sócio-econômico a estes investimentos têm prejudicado imensamente o processo de desenvolvimento. Foi proposta a criação de uma Lei de Política Habitacional e Reforma Urbana que contemplaria os seguintes pontos: a criação de um órgão executor da política urbana, a criação de um fundo nacional de habitação e a elaboração de um plano nacional de gestão territorial e de um plano nacional de habitação. $O$ debate sobre reforma urbana foi paralisado com o golpe militar de 1964.
}

[Digite texto] 
atravessava, sequer previsto na Constituição Federal de 1967, concentrava-se na esfera federal e se corporificava nas intervenções autoritárias diretas nas políticas locais.

Aos poucos os problemas de desenvolvimento urbano inseriam-se no quadro geral do processo de desenvolvimento econômico e social do país. Ainda na década de 1960, procurou-se incentivar a participação de algumas prefeituras na obtenção de financiamentos para planos de desenvolvimento local integrado junto ao FINEP- segundo documento "Sistema Nacional de Planejamento Local Integrado" elaborado, na época pelo Setor de Planejamento Regional e Municipal.

O Sistema de Planejamento que vinha se estruturando no país estava diretamente associado às políticas econômicas. Aos poucos a conscientização de atrelar planejamento ao orçamento foi se institucionalizando de modo a supostamente prever e garantir as grandes realizações de projetos e programas do governo. Assim, em 1972, o Sistema de Planejamento foi regulamentado pelo Decreto 71.353 , passando a compreender as atividades de planejamento, orçamento e modernização administrativa; e em 1974, buscando consolidar o sistema, passou-se a garantir a liberação automática de recursos orçamentários em razoável consistência em relação aos programas setoriais e do Plano Geral de Governo.

Outros órgãos foram criados nos anos de 1970, como a SAREMSecretaria de Articulação com os Estados e Municípios no Ministério do Planejamento e Coordenação Geral, a fim de prestar assistência técnica e colaborar com os governos estaduais e municipais visando interesse maior do planejamento em nível nacional e a criação do Centro de Planejamento Metropolitano do Ministério do Interior com a efetiva atuação do SERFHAU, nos estudos elaborados até o reconhecimento da realidade das regiões metropolitanas no país e a criação da CNPU- Comissão Nacional de Regiões Metropolitanas e Políticas Urbanas com base nas regiões metropolitanas como uma nova unidade territorial e que impunha novas concepções à administração pública.

O SERFHAU foi de fundamental importância na conscientização da realidade metropolitana do país a partir de estudos e grupos de trabalho que foram transferidos para a Secretaria Geral do MINTER sob a denominação de [Digite texto] 
Centro de Planejamento Metropolitano, ao qual competia realizar estudos e pesquisas e participar do processo de planejamento das regiões metropolitanas do país. Embora se percebam alguns avanços institucionais com relação à realidade das metrópoles, todo tipo de controle estaria exclusivamente a cargo do governo federal.

Durante a década de 1970, o principal objetivo na elaboração dos Planos Nacionais de Desenvolvimento seria a integração do território nacional desenvolvendo políticas de investimentos a partir de incentivos fiscais e mecanismos prioritários de transferência de recursos às regiões consideradas menos desenvolvidas como as do norte, do nordeste e do centro-oeste. $\mathrm{Na}$ dimensão política, privilegiaria a descentralização administrativa entre os níveis de governo e a contribuição democrática da população nos projetos e programas comandados pelo Ministério do Interior, que preconizava a articulação em todos os níveis de governo na perspectiva do planejamento regional apoiado pela teoria dos pólos de desenvolvimento à época.

A fim de atrelar as orientações gerais do governo aos Planos Nacionais de Desenvolvimento, foram criados em 1974, no âmbito da Presidência da República, o CDE- Conselho de Desenvolvimento Econômico e a SEPLANSecretaria de Planejamento (pela transformação do Ministério do Planejamento e Coordenação Geral e atualmente Ministério do Planejamento, Orçamento e Gestão) para assessorarem o governo federal e o suprir de condições de flexibilidade e amplitude de ação nos investimentos setoriais, assim como para formular política econômica.

Embora o Sistema de Planejamento se reafirmasse na esfera federal, a tendência centralizadora legitimada pelos planos, programas, leis e normas impediam maiores avanços institucionais do planejamento em nível estadual e municipal. Pela forma como foram constituídas, as instituições estaduais reforçaram os vínculos financeiros, técnicos e programáticos com a estrutura organizativa do governo federal mais do que com os sistemas estaduais de planejamento.

A maioria das entidades e empresas que atuariam na oferta de bens e serviços públicos nos Estados era da esfera federal, com ou sem repartições ou representações estaduais, como: o DNER/DEERs (Departamento Nacional de Estradas de Rodagem/Departamentos Estaduais de Estradas de Rodagem), 
$\mathrm{BNH} / \mathrm{COHABs}$ (Banco Nacional da Habitação/ Companhias Estaduais (ou Municipais) de Habitação), ELETROBRAS/CEEs (Centrais Elétricas Brasileiras S.A./ Comissões Estaduais de Energia), EMBRATUR (Empresa Brasileira de Turismo), EMATER (Empresa de Assistência Técnica e Extensão Rural), TELEBRAS (Telecomunicações Brasileiras S.A), entre outras que se integrariam à administração descentralizada; assim, seus programas de investimentos escapariam ao controle orçamentário e de planejamento estadual. O esvaziamento dos Estados não se ateve apenas aos recursos, mas principalmente às instituições e ao próprio sistema de planejamento estadual. Situação muito favorável às políticas clientelistas dos governos estaduais, fato que comprometeria o planejamento regional e as relações de ordenamento territorial entre Estados e municípios.

Quanto ao despreparo político e administrativo do sistema de planejamento municipal, os órgãos e entidades de governo local contaram sempre com a presença de organizações representativas das elites empresariais no ordenamento de seu território. Após a Constituição Federal de 1988, que considerou de maneira explícita a autonomia municipal, foi que ocorreu uma preocupação maior, pelo governo da União, em ordenar seus territórios e inseri-los ao planejamento e a rígido controle fiscal. Na maioria dos municípios, a fragilidade ou ausência das instituições regionais desfavoreciam os contratos entre municípios e entre estes e respectivos Estados em vista das funções públicas de interesse comum do desenvolvimento regional. Portanto, na maioria dos casos, os novos arranjos territoriais reforçavam as influências diretas locais de órgãos e entidades do governo federal sobre o ordenamento territorial dos municípios.

A crise econômica externa dos anos de 1980 desencadeou um quadro de profundo déficit nas contas públicas, o esgotamento do modelo nacional desenvolvimentista e uma lenta regressão da política regional. Houve um desmonte institucional dos sistemas nacionais e subnacionais de planejamento de médio e longo prazo no país e as políticas econômicas passaram a priorizar resultados de curto prazo, de estabilização monetária e financeira e combate à inflação.

O aumento de Carga Tributária Bruta no Brasil nos últimos anos resultou na diminuição da participação relativa de Estados e municípios no bolo [Digite texto] 
tributário, resultando não só em uma reafirmação dos conflitos federativos verticais e horizontais, mas também, a um impacto negativo sobre a possibilidade de utilização das transferências tributárias como mecanismo de diminuição dos desequilíbrios regionais (Jaime Jr e Crocco, 2005).

Não obstante, após as transferências voluntárias e outros tipos de transferências, a participação relativa dos municípios aumentaria em detrimento dos Estados e da União. Não haveria nenhum problema no aumento da participação relativa dos municípios no total da arrecadação tributária nos três níveis de governo. A questão central neste ponto seria que grande volume de transferências voluntárias impõe às subunidades federativas uma posição de dependência em relação a recursos federais.

Uma das características fundamentais do federalismo é a garantia de maior autonomia aos níveis de governo a partir da possibilidade de maior independência na arrecadação própria e definição clara de transferências constitucionais, portanto não dependentes de articulação voluntárias com as esferas superiores. A eventual dependência dos municípios ou Estados de transferências voluntárias do governo federal fere um dos princípios caros ao sistema federativo que é a autonomia e a descentralização dos recursos tributários (Jaime e Crocco, 2005).

No ano de 1990, no contexto das grandes reformas do governo, após um processo de esvaziamento e enfraquecimento das instituições e órgãos de desenvolvimento regional, foi extinto o MINTER e pelo mesmo ato foi criada a Secretaria de Desenvolvimento Regional na estrutura administrativa da Presidência da República, com a finalidade de planejar, coordenar, supervisionar e controlar a ação dos órgãos e entidades federais que atuassem em programas e projetos de desenvolvimento regional e também para articularse com órgãos congêneres dos Estados, do Distrito Federal e dos municípios.

Ainda em 1990, com o processo de reformas do governo, foi criada a Secretaria de Assuntos Estratégicos - SAE e a ela subordinada a DOTDiretoria de Ordenação Territorial de modo a cumprir com o preceito do art. 21 da Constituição Federal de 1988 que designa à União a competência de elaborar e executar planos nacionais e regionais de ordenação do território e de desenvolvimento econômico e social. E em 1999 a SAE foi extinta e parte de suas atribuições transferidas ao Ministério do Meio Ambiente; e em 2003 a 
responsabilidade do ordenamento territorial foi conferida ao Ministério de Integração Nacional e ao Ministério de Defesa.

De uma forma não muito aprofundada e na ausência de um projeto nacional claro e capaz de explicar a lógica do ordenamento territorial, foi lançada a PNOT- Política Nacional de Ordenamento Territorial, como uma preocupação com a retomada do território como base de integração de políticas produtiva, social e ambiental, na perspectiva de reduzir as desigualdades regionais e ativar os potenciais de desenvolvimento das regiões brasileiras. O ideário do ordenamento territorial contribuiria para aumentar a eficácia e eficiência das políticas públicas e dar sustentabilidade aos meios de desenvolvimento regional e local, promover a cessão e integração da sociedade nacional, reafirmar o pleno exercício da soberania sobre o território e consolidar a governabilidade. (PNOT- Ministério de Integração- Documentos de base para a definição de uma Política Nacional de Ordenamento Territorial, 2006).

O grande desafio em inserir políticas de ordenamento territorial está em romper com a perspectiva de ordenamento do território nacional do passado situado na escala nacional sem maiores perspectivas de desdobramento institucionais nas demais esferas do governo. Como ao longo dos anos as políticas regionais estiveram desvinculadas do ideário maior das políticas de ordenamento territorial, retomar a questão impõe profundas mudanças no âmbito institucional e administrativo que considerem novas percepções e concepções do mundo atual. .

A década de 1990 ficou marcada pelas alterações e indefinições das atribuições de competências entre secretarias e ministérios encarregados do planejamento regional do país. Em 1992 a Secretaria de Desenvolvimento Regional transformou-se em Ministério de Integração Regional, sendo-lhe atribuídas as competências relativas aos programas e projetos de integração regional; desenvolvimento urbano; relação com Estados e municípios; irrigação e defesa civil. Após algumas reformas organizacionais, em 1998 foi extinto o Ministério da Integração Regional e criada a Secretaria Especial de Políticas Regionais até que em 2003 foi criado o Ministério de Integração Nacional juntamente com o retorno das superintendências de desenvolvimento das 
regiões consideradas menos desenvolvidas, SUDAM, SUDENE E SUDECO e os respectivos fundos de financiamento e desenvolvimento regional.

Assuntos pertinentes ao ordenamento territorial encontram-se compartimentados em ministérios como no caso da questão urbana refletida no Estatuto das Cidades e no próprio Ministério das Cidades que vão ao encontro das políticas nacionais de ordenamento territorial. Reconhecer a realidade das regiões metropolitanas e avançar nos aspectos institucionais e administrativos imporia uma reforma estrutural de tal forma que seria até mesmo incompatível com a realidade do país. Em todos os níveis do governo reflete-se a citada organicidade desconexa de um ideário maior de ordenamento territorial.

Impõe-se reconhecer que a eficácia das políticas de ordenamento territorial estão diretamente relacionadas ao processo de democratização e descentralização. Para que de fato as políticas de ordenamento territorial se tornem efetivas, são necessários avanços institucionais e administrativos, sociais e de infraestrutura em qualquer país. No caso da França, políticas de ordenamento territorial se articulam com as políticas regionais num objetivo comum de desenvolvimento com os aportes institucionais e administrativos, numa realidade de acentuadas disparidades inter-regionais.

No caso do Brasil, as tentativas de se implementar políticas de ordenamento territorial esbarram no déficit institucional e administrativo e nas históricas medidas centralizadoras de poder e controle no governo federal. Assim, torna-se relevante, na perspectiva do ordenamento territorial, avaliar a importância das relações horizontalizadas diante das limitações das relações verticalizadas do governo no atual momento, em que se reacende a importância das políticas integradas para o desenvolvimento do país. 


\subsection{Capítulo 4 - A integração vertical e horizontal na} perspectiva territorial: os desequilíbrios nas relações entre governos

As relações intergovernamentais passaram a ser de extrema importância no ordenamento territorial. Ao longo de sua história, Estados e municípios tiveram períodos de ascensão e de queda da importância de seus papéis no ordenamento do território e na redução das desigualdades regionais. Ao passo do processo de democratização e descentralização no país, a autonomia delegada aos Estados e municípios esteve muito mais ligada à desoneração de encargos e obrigações dos governos federal e estadual do que na real capacidade autônoma política, administrativa, financeira e tributária dessas instâncias.

A história republicana brasileira consagrou um modelo concentrador do poder político com o Poder Executivo, na dimensão horizontal e o governo central na dimensão vertical. Essa afirmação se corrobora pela própria formação da estrutura fortemente hierarquizada de distribuição de poder pelos governos verticalmente. As relações federativas enfrentaram inúmeras limitações ao seu desenvolvimento e sempre estiveram sujeitas de um lado, às vicissitudes dos diferentes momentos políticos e, de outro, às barganhas e aos arranjos de compromissos estabelecidos, caso a caso, entre o governo nacional e as oligarquias regionais e locais, o que de maneira geral, contribuiu para obstruir o desenvolvimento, perpetuar as desigualdades territoriais e servir de obstáculos às políticas de ordenamento territorial.

Ordenar o território tendo por base os princípios do federalismo se tornou um grande desafio em conciliar conflitos oriundos do processo de democratização, descentralização e ampliação das políticas sociais dispostas na última Constituição Federal de 1988. Ao elevar o município à categoria de ente federativo autônomo, mudanças nas relações políticas entre os níveis de governo, estariam presentes no que foi chamado de "novo federalismo" no país. O processo de descentralização democrática no país e o esgotamento do modelo desenvolvimentista de governo resultaram na expressiva perda da 
reprodução do aparelhamento do território de forma a atender às demandas dos setores produtivos e às necessidades sociais e ambientais.

Valendo-se das características da federação brasileira, segundo Ribas Vieira (1999:65), a federação está estruturada em duas ordens jurídicas bem definidas: a da União Federal e a dos Estados-membros que convivem bem segundo suas respectivas competências. No entanto, a federação brasileira apresenta uma atipicidade porque o município constituiu uma ordem jurídica sui-generis no arts. 29 e 30 da Constituição Federal de 1988, que designam autonomia a essas instâncias.

A descentralização, o federalismo fiscal e a autonomia dos governos subnacionais são pontos fundamentais na articulação de políticas de desenvolvimento regional no Brasil. Embora, os municípios tenham se beneficiado com a ampliação de suas competências tributárias pela ampliação das transferências do governo central e dos Estados na última Constituição Federal, os acúmulos de gastos sociais, as medidas restritivas quanto à capacidade tributária e a política de recentralização dos recursos pelo governo central vêm impondo sérias dificuldades para a ordenação de seus territórios, principalmente em se tratando de municípios centrais das grandes metrópoles do país.

Segundo Varsano (1997:19) um problema básico do federalismo fiscal consiste na busca de um equilíbrio entre, de um lado, a necessidade de garantir um grau razoável de autonomia financeira e política aos diferentes níveis de governo e, de outro, a necessidade de coordenação e sistematização dos instrumentos fiscais em termos nacionais. A experiência brasileira tem sido especialmente marcada pela dificuldade em se atingir uma compatibilização destes dois objetivos, registrando ciclos de menor ou maior centralização de poder tributário que por sua vez, acompanham estreitamente a evolução histórica de regimes políticos, mais democráticos ou de menor difusão de poder.

No entanto, o processo de descentralização política foi acompanhado do aumento de fluxos intergovernamentais de recursos transferidos aos municípios, que apresentam bases tributáveis frágeis diante da estrutura organizativa de dados e cadastro que devem estar sempre atualizados, e que sem os devidos incentivos à coordenação e cooperação entre os demais níveis 
de governo, encontram-se sem as condições administrativas, financeiras e políticas para usufruírem os recursos disponíveis de forma proveitosa. Além disso, há a considerar a crescente informalidade no setor de serviços e as dificuldades para regulamentar atividades tributáveis, o que reduz a capacidade fiscal dos municípios.

A municipalização prevista pela última constituição federal considera o município como entidade político-administrativa com ampla capacidade tributária e assegurou autonomia em tudo quanto diz respeito ao seu peculiar interesse. No entanto, a maioria das administrações locais não está politicamente educada e tecnicamente preparada para dirigir o município com a autonomia que a Constituição Federal Ihe assegura. O município assumiu todas as responsabilidades na ordenação da cidade, na organização dos serviços públicos locais e na proteção ambiental de sua área, em condições agravadas a cada dia pelo fenômeno avassalador da urbanização que invade os bairros e degrada seus arredores com habitações clandestinas e carentes dos serviços públicos essenciais ao bem-estar da população (Meirelles, 2006).

As regras do federalismo brasileiro predominantes nas décadas de 60 e 70 desestimulava de modo coercitivo o esforço fiscal local a favor de um centralismo de recursos e redistribuição dos mesmos segundo critérios que desfavoreciam municípios, principalmente os municípios das grandes metrópoles. O federalismo brasileiro baseado nas transferências intergovernamentais e nas restrições para uma gestão tributária descentralizada conduzia à dependência da assistência financeira federal aos municípios.

Ao longo dos anos, os Estados federativos sofreram redução gradativa de recursos tributáveis, mas segundo a autonomia em determinar sua política tributária e conceder isenções de impostos, as políticas de desenvolvimento regional deram lugar à chamada "guerra fiscal". Por sua vez, o governo federal manteve o poder normativo e o poder de barganha com Estados e municípios a partir de mecanismos legais e financeiros, agindo no ordenamento territorial nacional em detrimento das propostas de planejamento regional integrado. A autonomia concedida a Estados e municípios foi acompanhada por medidas restritivas orçamentárias desfavoráveis às relações intergovernamentais e às políticas regionais de desenvolvimento. 
O aumento da Carga Tributária Bruta no Brasil veio acompanhado por uma recentralização tributária. A estratégia de elevação da Carga Tributária Bruta nos últimos dez anos resultou na diminuição da participação relativa de Estados e municípios no bolo tributário, resultando não só em uma reafirmação dos conflitos federativos verticais e horizontais, mas também, em um impacto negativo sobre a possibilidade de utilização das transferências tributárias como mecanismo de diminuição dos desequilíbrios regionais (Jaime Jr e Crocco, 2005).

Ao considerarmos que o federalismo é uma forma de ordenamento político do território porque define as relações entre os níveis considerados autônomos, o compartilhamento das atribuições e o processo decisório entre eles tornam-se de extrema importância em nossa análise. Contraditoriamente ao governo unitário, o federalismo permite que mais de um governo atue na elaboração de políticas de ordenamento territorial. Mesmo que verticalmente sejam estabelecidas competências para cada nível de governo, os pactos territoriais horizontalmente estabelecidos entre os níveis de governo adquirem grande relevância no ordenamento territorial urbano, principalmente nas grandes metrópoles.

Nos casos de países de grande extensão territorial e acentuadas desigualdades naturais, culturais, políticas e sociais inter-regionais como o Brasil, o ideário do federalismo permitiria maior controle dessas heterogeneidades e consequentemente, da estabilidade social do país. A proposta do ordenamento territorial no quadro de heterogeneidades necessitaria de se criar uma ideologia nacional alicerçada por instituições e baseada no discurso e prática da unidade na diversidade.

As regiões metropolitanas e as aglomerações urbanas, resultado de uma extensa urbanização, impõem novos arranjos territoriais e administrativos que ultrapassam os limites territoriais político-administrativos das unidades federativas e desafiam a capacidade do poder público de controlar e oferecer bens e serviços públicos acessíveis à população tendo por restrição segundo o federalismo brasileiro, as competências delegadas às unidades políticoadministrativas em seus respectivos territórios. Assim, a visão que se instalou nos sistemas federativos de políticas públicas, consistiria em acordos ou negociações entre Estados e municípios autônomos, tanto na elaboração 
quanto na implementação dos programas governamentais quanto na gestão de bens e serviços à população, a partir do que passou a ser denominado associativismo territorial.

Experiências internacionais demonstram que o associativismo territorial tem se desenvolvido em torno de dilemas de coordenação e cooperação entre os níveis de governo principalmente em áreas conurbadas ou metropolitanas. Outras formas de administração territorial surgem como consorciamento e parceria entre os níveis de governo para solucionarem problemas de oferta de bens e serviços públicos. Soma-se a essas duas formas de administração territorial a necessidade imposta pela otimização da gestão pública local eficiente e eficaz com total responsabilização dos agentes públicos, num sistema federativo que designa autonomia aos níveis de governo.

O federalismo impõe uma divisão de poderes e as decisões políticas tornaram-se interdependentes entre os níveis de governo resultando em conflitos intensos nas relações intergovernamentais. O ordenamento territorial na forma de governo federalista tornou-se reflexo de práticas competitivas e cooperativas de novos arranjos territoriais que podem ferir os princípios da federação, como as "guerras fiscais", ou cooperação que pode aniquilar a autonomia dos governos subnacionais.

No caso do Brasil, alguns avanços nos consórcios territoriais são identificados, mas o que se percebe são mecanismos de coordenação intergovernamental a partir de normas estabelecidas e da redistribuição de recursos do governo federal aos municípios. Os Estados são excluídos desse processo corroborando ao desequilíbrio intergovernamental e regional. Tal modelo define o papel coordenador, indutor e financiador do governo federal numa articulação descentralizadora em direção aos municípios e enfraquece a perspectiva metropolitana das políticas públicas.

Diante das citadas heterogeneidades do país e das características do federalismo brasileiro expostas, os mecanismos de coordenação, cooperação, parcerias e consórcios entre os níveis de governo impõem condições como uma forte identidade regional alicerçada por instituições competentes e coordenação a fim de conciliar os conflitos daí gerados. O ordenamento territorial hoje, ao contrário do período do governo autoritário, admite o associativismo territorial como um dos mecanismos favoráveis à própria gestão 
de bens e serviços públicos, conciliando muitos conflitos numa perspectiva regional e setorial. Isso indica que essa é uma direção em que o Brasil necessitaria avançar muito mais.

Alguns desafios são lançados ao modelo federalista diante da proposta de ordenamento territorial que impõe novas concepções de entidades territoriais, que entrecruzam diferentes níveis de governo verticalmente e horizontalmente e que estão sujeitas às mais diversas influências políticas. $O$ processo de descentralização do governo veio no contexto de reformulação da administração pública necessária para a obtenção de um desempenho mais eficiente do aparato governamental, transferindo poder e autoridade administrativa inclusive às organizações que não fazem parte da administração pública direta, como empresas públicas, agências regionais de desenvolvimento e organizações não governamentais ${ }^{25}$.

Tal tendência desencadeou uma perda progressiva do controle e planejamento na esfera pública, pondo em risco a própria capacidade de governança tão necessária para as propostas de planejamento integrado como base para o governo formular e implementar políticas; e apontou em direção de novas percepções e concepções do planejamento do desenvolvimento territorial e mudanças nos modelos administrativos e institucional do país.

Em vista de conciliar diferentes realidades expressas no território e estrategicamente manter as políticas de desenvolvimento, muitos países sob o federalismo como forma de governo, seriam capazes de estabelecer um sistema de divisão das atribuições e recursos do governo pelos seus níveis a

\footnotetext{
25 Segundo Gohn (1997:301) expõe que a construção de uma nova concepção de sociedade civil é resultado das lutas sociais empreendidas por movimentos e organizações sociais nas décadas anteriores, que reivindicaram direitos e espaços de participação social. Essa nova concepção construiu uma visão ampliada da relação Estado-Sociedade, que reconhece como legítima a existência de um espaço ocupado por uma série de instituições situadas entre o mercado e o Estado, exercendo o papel de mediação entre coletivos de indivíduos organizados e as instituições do sistema governamental. Este espaço é trabalhado segundo princípios da ética e da solidariedade, enquanto valores motores de suas ações, resgatando as relações pessoais, diretas, e as estruturas comunitárias da sociedade, dadas pelos grupos de vizinhança, parentesco, religião, hobbies, lazeres, aspirações culturais, laços étnicos, afetivos etc. No Brasil, esse papel passou a ser desempenhado pelas ONGs, que fazem a mediação entre aqueles coletivos organizados e o sistema de poder governamental, como também entre grupos privados e instituições governamentais. Uma nova institucionalidade se esboçou a partir desta visão de mundo, na qual se observa a reformulação da concepção de esfera pública e do que lhe pertence. Isso resultou na construção de uma nova esfera, ou subesfera, entre o público e o privado, que é o público não-estatal, e no surgimento de uma ponte de articulação entre estas duas esferas, dada pelas políticas de parceria.
}

[Digite texto] 
fim de garantir as intervenções governamentais e sua soberania em todo o território nacional.

A forma e o sistema de governo de um determinado país implicam diretamente nos propósitos do ordenamento territorial, que deixou de ser apenas uma atribuição do governo central e passou a incorporar princípios de descentralização e de democratização entre os níveis de governo. O ideário do ordenamento territorial está estritamente relacionado à capacidade autônoma e organizativa de cada nível de governo em cumprir com suas respectivas competências no contexto da descentralização política e das relações intergovernamentais.

De modo conflituoso, a proposta do ordenamento territorial vem se tornando um tema político importante diante do quadro de crise que se estabeleceu entre as formas e sistemas de governos centralizadores, nacionalistas e autoritários. O ordenamento territorial impõe reformas governamentais diante de uma realidade de novas repartições de poderes sobre o território, de novas influências geopolíticas, dos desafios lançados às administrações públicas e às mudanças do papel do governo no mundo de relações globalizadas.

O ordenamento territorial deixou de ser apenas uma incumbência de um único representante político intervir sobre o território e passou a ser a capacidade de produzir uma unidade numa sociedade marcada por múltiplos atores e seus respectivos interesses. Por sua vez, a forma e o sistema de governo dos países implicam diretamente nos cenários de atores e interesses no ordenamento territorial. Muitas experiências estrangeiras de planejamento regional no sistema federalista de governo influenciaram as políticas de ordenamento territorial no Brasil.

Tanto a forma quanto o sistema de governo do país expressam o entrecruzamento do federalismo com o presidencialismo, de extrema importância na configuração territorial e regional do país. O sistema presidencial de governo do Brasil caracterizou-se pela concentração e controle do governo central às propostas de estabilização econômica e às políticas de desenvolvimento no âmbito do ordenamento de seu território. 
O sistema de governo brasileiro, distante do ideário do federalismo cooperativo $^{26}$, permitiria, na implantação de programas e projetos de interesse nacional, agregar procedimentos operacionais que incluíssem repartição de custos entre os níveis de governos, impor orientações federais e compartilhar administrações, mesmo que os beneficiados sejam de um determinado local, de um Estado ou região.

No entanto, programas e projetos relacionados à construção de vias expressas, saneamento, aeroportos, e habitação, entre outros investimentos de infraestrutura local ou regional, conduzem Estados e unidades políticas locais a serem submetidos aos programas e projetos do governo federal. Os conflitos de interesses políticos locais e regionais tornam-se mais acirrados e passam a exigir eficiente estrutura de planejamento do ordenamento territorial numa perspectiva de integração horizontal em contraposição ao simples discurso a favor do interesse nacional.

Embora as reformas ocorridas e as que estão por vir enfatizem a política descentralizada entre os níveis do governo, por outro lado, as leis e normas ratificam o poder de centralização dos recursos e decisões do governo federal e de dependência dos demais níveis do governo. As restrições e controles orçamentários impostos aos Estados e municípios, embora sejam consideradas verdadeiros avanços ao maior controle do déficit público, reforçam as tradicionais unidades político-administrativas sobre o território e impedem decisões fundamentais para o pleno exercício da autonomia desses níveis de governo numa perspectiva regional de desenvolvimento. Os problemas são lançados aos municípios que devem buscar solucioná-los de modo a desonerar o governo central de encargos e atribuições.

Os municípios atualmente se deparam com desafios impostos pelo aumento de suas atribuições como a organização administrativa descentralizada de políticas sociais e a centralização das políticas fiscais. Soma-se a esse quadro, o crescente déficit de capacidade de gestão e de financiamento dos municípios quando a maioria depende das transferências do governo federal. O impasse está nas dificuldades dos municípios em elevar

\footnotetext{
${ }^{26}$ Vieira (1999:64) cita um novo caminho para materializar a federação na Alemanha quanto a lei fundamental de 1949 cujo sistema federativo por cooperação baseia-se num processo harmonioso de responsabilidade e de redistribuição equilibrada das competências constitucionais.
}

[Digite texto] 
suas arrecadações e reduzir o déficit público, bem como na adoção dos mecanismos de controle social pelo governo.

No caso de um sistema financeiro em bases nacionais e não regionais como é o caso do Brasil, as políticas de desenvolvimento regional não podem ser estudadas sem a conexão com mecanismos fiscais de financiamento público, a natureza do federalismo fiscal e a Lei de Responsabilidade Fiscal $(\mathrm{LRF})^{27}$. A partir de meados da década de 1980, concomitantes ao processo de redemocratização, ocorreram as demandas por maior descentralização tributária. A descentralização, federalismo fiscal e autonomia de governos subnacionais são pontos fundamentais na articulação de políticas de desenvolvimento regional no país. O financiamento do desenvolvimento regional encontraria ecos na distribuição dos recursos tributários e na autonomia dos entes federativos (Jayme Jr e Crocco, 2005).

O poder atribuído ao governo federal se impõe aos demais níveis de governo definindo as bases tributáveis, centralizando a maior parte dos recursos tributáveis, transferindo parcelas aos demais níveis do governo, estabelecendo as transferências entre governos e mantendo controle rígido das finanças públicas. As medidas de controle do orçamento público impostas aos entes federativos se inserem no contexto de ajuste fiscal para garantir as condições exigidas a fim de que sejam estabelecidas relações financeiras diretas dessas instâncias com os organismos financeiros multilaterais.

A adoção da LRF permitiu aos municípios maiores a realização de operações de crédito junto aos organismos externos como o BID (Banco Interamericano de Desenvolvimento), BIRD (Banco Internacional para

\footnotetext{
27 Segundo Holanda (1993:8) nos países subdesenvolvidos, geralmente o problema decorre de as receitas dependerem de uma base tributária que, além de pequena, é instável e sensível às flutuações da conjuntura, enquanto os gastos públicos são rígidos, dado que se destinam principalmente ao pagamento de salários do funcionalismo público. Existem pressões para ampliar o emprego no setor público, que funciona, quase sempre em condições de ineficiência generalizada. A execução orçamentária e sua articulação com o sistema de planejamento são deficientes. A situação torna-se difícil para aqueles países que apresentam um padrão de desenvolvimento "intermitente". As interrupções periódicas do processo de crescimento afetam a base tributária mas, não reduzem antigos compromissos e novas demandas sociais, o que leva ao financiamento dos gastos por déficits orçamentários. Isso, por sua vez, implica custos futuros mais elevados para o serviço da dívida pública. 0 descompasso entre o crescimento instável ou insuficiente de receitas, de um lado, e uma constante e irreversível pressão de demandas sociais, de outro, geram a crise fiscal. Por isso, o governo precisa adotar medidas "para proteger" a sua capacidade orçamentária, o que envolve tanto questões de formulação de políticas, como questões processuais ou operacionais.
}

[Digite texto] 
Reconstrução e Desenvolvimento) e BNDES (Banco Nacional de Desenvolvimento Econômico e Social), possibilitou maior credibilidade aos tribunais de contas dos Estados e municípios no controle das contas públicas, ou melhor, da chamada accountability pública. Em outras palavras, a LRF se insere no contexto mais amplo de ajuste das finanças públicas de participação da sociedade quanto ao orçamento público, de ajuste aos limites impostos e de planejamento orçamentário de médio e longo prazo por meio de instrumentos como os planos plurianuais e as leis orçamentárias, prestação de contas dos gestores públicos e de restrições das transações entre governos.

A LRF deu início a um novo processo institucional no contexto participativo de múltiplos atores que criaram interpretações jurídicas, econômicas e sociais para a referida lei. Esse processo, em um país que agrega tantas diferenças regionais, culturais e políticas poderá ter resultados específicos em diferentes Estados e municípios, principalmente no ordenamento de seus respectivos territórios.

A LRF, inserida nas administrações dos Estados e municípios, reforça muito mais resultados orçamentários e fiscais das políticas e programas nacionais do que as propostas de ordenar o território que não vão além das demonstrações de execução financeira dos gastos dos Estados e municípios; apesar dos avanços no disciplinamento fiscal e administrativo do governo, a LRF reforçou impactos políticos sobre as relações intergovernamentais e sobre as políticas públicas.

Assim, no Brasil, as políticas de ordenamento territorial se deparam com o enfraquecimento e esvaziamento do papel político dos Estados na elaboração das políticas regionais e com a valorização das relações diretas do governo federal com os municípios. A forma de governo do Brasil assemelhase à forma de governo da Argentina, que prevê a coexistência de dois níveis de governo: o federal e os governos locais. As províncias argentinas corresponderiam aos Estados federativos brasileiros, casos em que ambos possuem sua própria constituição subjugada à constituição federal, perderam ao longo do tempo seu poder de ordenamento territorial e encontram-se reféns da chamada "guerra fiscal" para atraírem unidades industriais.

Apesar da Constituição Federal da República Federativa do Brasil de 1988 definir o compartilhamento de poder entre os níveis local, regional e 
nacional; ao longo da história observamos um modelo concentrador do poder político no Poder Executivo no âmbito horizontal das relações estabelecidas e o governo federal nas relações estabelecidas na verticalidade entre os níveis de governo. No entanto, os avanços nas relações federativas foram limitados pelas relações estabelecidas entre o governo federal e as oligarquias regionais e locais que impediam a implementação das políticas de desenvolvimento e perpetuavam as disparidades regionais.

Como no Brasil e na Argentina, os demais assuntos políticos e administrativos dos Estados federativos do governo brasileiro ou das províncias no governo argentino estão submetidos à avaliação e aprovação pelo Congresso que se encarrega de modo bastante centralizado dos mesmos, entre outros assuntos, principalmente os relacionados ao ordenamento territorial como vistas as contribuições de recursos das províncias ao governo federal, para garantir a prosperidade do país e o bem-estar das pessoas, elaborando planos de instrução geral e universal, progresso econômico com justiça social e o equilíbrio das desigualdades entre províncias e regiões.

Reforce-se a evidência de que a partir da Constituição Federal de 1988 um novo arranjo federativo foi estabelecido entre os níveis de governo com relativo esvaziamento dos recursos e do papel político dos Estados no ordenamento territorial e considerável aumento do peso político dos municípios na implementação das políticas públicas nacionais descentralizadas. A redução do papel dos Estados no ordenamento de seus respectivos territórios resultou na dependência de políticas de ajuste fiscal e de estabilização macroeconômica e numa crise política e institucional capaz de imobilizar suas ações de expansão e fornecimento de serviços públicos à população.

Dessa forma, o crescimento das ações descentralizadas reforçou o novo arranjo federativo em que convênios e transferências de recursos do governo federal são diretamente efetivados com os municípios principalmente na implementação de políticas sociais. Os municípios passaram a estabelecer relações diretas com os organismos financeiros multilaterais. Os Estados tiveram seu importante papel no planejamento regional do ordenamento territorial esvaziados pela crise política e institucional a que foram submetidos.

No entanto, o arranjo federativo e a crise política e institucional dos anos de 1980 e 1990 que se abateu sobre os Estados brasileiros foram justificativas [Digite texto] 
apresentadas para a extinção de órgãos e entidades que permeavam entre os níveis de governo para efetivarem políticas públicas de ordenamento territorial integradas. Poucos Estados efetivamente apresentam atualmente entidades capazes de desenvolver ações governamentais que integrem efetivamente as ações dos diferentes níveis de governo.

Pretende-se reconhecer o despreparo institucional e administrativo do país em implementar políticas de ordenamento territorial integradas que se sobreporiam aos obstáculos que se apresentam nas relações verticalizadas e horizontalizadas do governo. Ou seja: o ordenamento territorial impõe novos pactos territoriais e profundas reformas política, administrativa, financeira e tributária do governo para uma eficaz gestão territorial.

Trata-se de uma ação técnica concatenada aos princípios científicos e aliados ao posicionamento político de todos os envolvidos no ordenamento territorial. Não será suficiente apenas mudar percepções e concepções do planejamento do ordenamento territorial, mas deverá haver, principalmente, uma conscientização da sociedade sobre as urgentes mudanças que se fazem necessária. Numa realidade de ausência de uma sistematização dos instrumentos urbanísticos, cabe uma análise da atual tendência do urbanismo no ordenamento territorial urbano no Brasil. 


\subsection{Capítulo 5 - O Ordenamento Territorial Urbano e sua constituição: uma avaliação dos instrumentos urbanísticos}

Que novas percepções e concepções assumiriam os instrumentos urbanísticos que auxiliam as políticas de ordenamento territorial urbano atualmente? Diante da obrigatoriedade de determinados instrumentos no planejamento do desenvolvimento urbano, como estaria a sistematização de cada instrumento na política urbana? Até que ponto a compartimentação de leis e normas urbanísticas no país contribui para as irregularidades nas intervenções urbanas?

O processo de redemocratização do país foi acompanhado pela descentralização da competência do ordenamento territorial ao nível local. A Constituição Federal de 1988 reconheceu a importância da esfera política local na elaboração dos planos urbanísticos e todo o aparato necessário ficaria a cargo do próprio governo local. De modo a desonerar o governo federal e descentralizar competências pelas instâncias do governo, o ordenamento territorial urbano foi reconhecido como de principal competência do governo local.

Embora a última constituição federal no art. 24 tenha determinado a todas as instâncias do governo a competência de legislar sobre o urbanismo, os municípios assumiram de vez o principal papel de planejamento local. Percebe-se que na constituição federal, a política de desenvolvimento urbano reduziu ao papel político do plano diretor a competência de ordenar o território urbano; e ao Estatuto da Cidade de 2001 a competência de precisar os instrumentos considerados adequados ao ordenamento do desenvolvimento das funções sociais da cidade e da propriedade urbana segundo diretrizes gerais.

No contexto de descentralização das atribuições entre os níveis do governo, o ordenamento territorial urbano seria o reflexo do ordenamento territorial nacional e regional refletido no local. Ao ser designada a política de desenvolvimento urbano aos municípios o ordenamento territorial urbano teria no plano diretor seu principal instrumento de política urbana para estabelecer a 
função social da propriedade urbana, as diretrizes de uso, domínio, zoneamento e ocupação do solo visando os princípios da sustentabilidade e do bem-estar de seus habitantes.

Ordenar o território local no contexto político e cultural ocidental constitui-se em ações que se expressam no urbanismo. No caso, trata-se do ordenamento restrito à menor unidade territorial-político-administrativa que é o município, e que se legitima pelos instrumentos legais e instituições locais. $O$ ordenamento territorial urbano implicaria numa lógica de apropriação e de domínio do espaço a partir da relação física dos objetos naturais e/ou sociais com a funcionalidade do território, visando o bem-estar da sociedade.

A ordem estabelecida em um território urbano seria mutável porque simboliza a síntese dos hábitos, culturas e influências políticas da sociedade de um determinado contexto histórico. Sendo assim, determinadas heranças de objetos naturais e socialmente construídos poderiam se tornar obstáculos para as novas adaptações do espaço ao processo contínuo de expansão do tecido urbano, em vista das novas tecnologias e dos novos arranjos territoriais. $O$ ordenamento territorial imporia constantes adaptações do espaço urbano à realidade das relações de uma determinada sociedade e à sua funcionalidade integrada.

O ordenamento territorial urbano necessitaria de um acordo simultâneo entre planejadores e juristas para que efetivamente o controle do uso do solo e o combate à especulação fossem rigorosos e limitadores à expansão urbana desordenada e priorizassem a socialização do solo urbano. $O$ zoneamento contribuiria para limitar a economia liberal e evitar um fracionamento excessivo do espaço urbano e a implantação dos equipamentos urbanos. Por exemplo: habitação não deveria se restringir à habitação familiar corrente (coletivo, individual ou de função), mas à habitação de solteiros (trabalhadores, jovens, estudantes, anciões), à habitação das comunidades (hospício, comunidades religiosas, hospitais, etc) e à habitação de população marginal (alunos internos, enfermos em tratamento, militares, etc) como uma visão mais rigorosa das necessidades locais com base nas heterogeneidades dos grupos sociais a ser consideradas pelos planejadores urbanos e apreciadas pelos juristas especializados em leis urbanísticas (Labasse, 1960). 
O ordenamento territorial local expresso no urbanismo teria na figura dos códigos de postura, de obras e de urbanismo ${ }^{28}$ os primeiros instrumentos que legitimariam intervenções do governo e da sociedade local até o plano diretor territorial como instrumento de planejamento físico, econômico e ambiental que dispõe de usos do solo e atividades, localização das estruturas e dos sistemas que possibilitariam uma maior integração funcional de todo o território planejado.

Para alcançar o bem-estar da população relacionado à funcionalidade do território, muitos aspectos se inserem no ordenamento do território urbano, como tempo de locomoção entre domicílio e trabalho, acessibilidade à rede de transportes, condições de habitabilidade, opções de lazer, opções de cultura e consumo, saúde e educação, proteção ao meio-ambiente, entre outros que se tornam verdadeiros desafios ao governo em ofertá-los nos grandes centros urbanos. Somam-se a esses, outros aspectos relacionados à funcionalidade do território como o número de transportes intermunicipais e inter-regionais e o tempo de locomoção assim como a infraestrutura em geral relevante ao ordenamento territorial urbano.

$\mathrm{O}$ ordenamento territorial urbano tem por objetivo a funcionalidade do território e o bem-estar da população. Sendo assim vários temas devem ser incluídos no processo contínuo e dinâmico do ordenamento territorial multidisciplinar e integrados às escalas regionais e nacionais, tais como o adequado uso e controle do solo urbano, o controle dos recursos hídricos, a disposição estratégica dos equipamentos, bens e serviços urbanos, política habitacional e saneamento, entre outros. $O$ ordenamento territorial urbano deve contar com uma estrutura de órgãos de planejamento integrados e competentes do governo, capazes de conciliar interesses públicos e privados sintetizados pelas comissões locais numa abordagem global, a longo prazo.

\footnotetext{
${ }^{28}$ O código de urbanismo seria um dos primeiros textos de ordenamento territorial urbano aos planos nacionais e locais referindo-se a gestão e equipamentos do solo. O aporte técnico do código de urbanismo é fundiário e os princípios jurídicos são fundamentados sobre os direitos de propriedade imobiliária. Seu propósito é político e social desde a matriz fundiária, o planejamento de seu uso a fim de promover condições de vida conforme algumas normas e necessidades do momento. Atualmente, o código de urbanismo ou de obras encontra-se compartimentados em leis de regulamentação e de direitos novos de utilização do espaço e de ocupação dos solos.
}

[Digite texto] 
Teoricamente, o código de urbanismo inspiraria a política nacional de ordenamento territorial e preveria o desenvolvimento ao plano local. O código de urbanismo refletiria o contexto histórico e político do momento em que foi elaborado, necessitando de constantes adaptações à própria dinâmica do espaço em construção. $O$ código de urbanismo deveria dar as diretrizes ao governo e à sociedade organizada local, com uma visão nacional do ordenamento das condições de vida, de gerir o solo de modo econômico, de assegurar a proteção dos meios naturais e sociais e de promover o equilíbrio entre as populações residentes das zonas urbanas e rurais, de harmonizar os conflitos de interesses das sociedades organizadas respeitando a reciprocidade de suas autonomias, suas previsões e suas decisões de utilização do espaço.

No Brasil, é de desejar que se chegue a um código de urbanismo que agregue as leis e normas urbanísticas. Código de posturas, código de obras, leis e normas urbanísticas encontram-se divididas e até desconexas uma das outras. Tal situação de certa forma permitiu ao longo dos anos que muitas ações e intervenções ocorressem à margem da legalidade e contribuíssem para um quadro complexo para as políticas de ordenamento urbano.

Os conceitos e princípios do ordenamento territorial urbano devem se estender e se relacionar aos atos concretos da administração pública local como uma nova forma de gestão pública do espaço urbano. As reformas na administração pública deveriam absorver conceitos e princípios do ordenamento territorial urbano, e pô-los em prática legitimados pelas novas normas de utilização do território definidas pela sociedade organizada local ou por um órgão ou entidade pública de cooperação intermunicipal, tanto nas zonas urbanas e rurais, relacionadas à adaptação do espaço urbano às novas tecnologias, implantação de novas redes de transportes e comunicações, promoção de habitações, de serviços sociais, de comércios, de financiamento, investimentos e empréstimos, de lazer e de turismo, organizações dos serviços públicos, localização de empresas, de valorização do patrimônio construído e não construído e dos espaços naturais, etc.

Do código de urbanismo até o plano diretor de desenvolvimento territorial, os instrumentos urbanísticos não seriam suficientes no ordenamento do território urbano em vista da dinâmica das relações sociais e adaptações do [Digite texto] 
espaço às novas tecnologias, embora assumissem papel fundamental no controle do solo e na qualidade de vida de seus habitantes. No entanto, ao longo dos anos, o governo local não dispõe dos mecanismos de ordenamento territorial urbano, que busquem consenso no conflito entre os interesses de cidadãos e empresas e baseiam-se principalmente nos fluxos de recursos financeiros disponíveis estabelecidos entre o governo e os estabelecimentos financeiros, que definem regras no código de urbanismo e os meios de obrigálas a serem cumpridas acabando por ordenar indiretamente o território local.

É necessário, no entanto, que os instrumentos urbanísticos sejam acompanhados por avanços jurídicos, institucionais e administrativos para que de fato, ordenar o território se torne realidade. O desafio de ordenar novos arranjos territoriais impõe novos pactos territoriais e profundas reformas jurídicas, institucionais e administrativas, principalmente na proposta de desenvolvimento das metrópoles. 


\subsection{Capítulo 6 - A questão metropolitana no Ordenamento Territorial: um desafio}

Mas, diante do grande desafio de ordenar o território diante dos novos arranjos territoriais, que decisão tomar? Impedir que novas aglomerações e metrópoles se formem? Ou encarar o grande desafio de ordenar esses espaços?

Partimos da concepção do quanto o ordenamento territorial urbano tornou-se uma proposta muito ambiciosa de promover um crescimento equilibrado ou simplesmente de conciliar as aspirações da população com as necessidades das empresas. Um dos maiores desafios do ordenamento territorial urbano estaria na luta contra a formação de metrópoles e megalópoles admitindo que a concentração seria inseparável do processo de desenvolvimento sobre o território. Portanto, as discussões envolvidas no ordenamento territorial urbano deveriam ater-se à necessidade ou não de frear o crescimento dos grandes centros urbanos nos debates entre os atores políticos envolvidos.

A expansão descontrolada e desordenada das metrópoles vem causando uma deterioração das condições de vida de seus habitantes e impõe determinadas intervenções pela própria ausência de controle e planejamento de seu crescimento. Segundo Parisi (1972: 227) a falta de controle da expansão das áreas metropolitanas tem deteriorado as condições de vida urbana e tem obrigado a realizar intervenções para permitir o funcionamento dessas áreas e para corrigir defeitos provocados pela mesma falta de controle. Paralelamente, o exagerado e descontrolado preço da terra nas áreas metropolitanas tem elevado desmesuradamente os custos de urbanização. (tradução nossa).

Alerta às políticas de ordenamento territorial urbano quanto aos fatores negativos, principalmente onerosos, gerados pelo gigantismo urbano e, portanto, pode-se chegar a conclusão de que seu crescimento deveria ser dirigido e limitado. Os elementos considerados para o mais eficiente e efetivo ordenamento territorial urbano seriam: o controle da utilização do solo baseado na prévia divisão do espaço urbano em áreas ou zonas, principalmente de habitação e recreação, capazes de frear a pressão expansionista e de 
possibilitar alcançar os resultados desejados; e, principalmente promover o combate à especulação urbana desenfreada, que se torna duplamente cara no momento da expropriação (Labasse, 1960).

Diante da realidade latino-americana das metrópoles ao se inserir no contexto do desenvolvimento político, econômico e social, foi realizado em 1972 um seminário latino americano no Chile $^{29}$ que buscava um aporte teórico, conceitual e metodológico-instrumental interdisciplinar para a elaboração de políticas de intervenção no domínio urbano-regional nos países latinoamericanos, apontou a necessidade imperativa de desenvolver a investigação científica em articulação com os problemas práticos, socialmente relevantes de nossos países, integrar as políticas de desenvolvimento metropolitano e regional nos esquemas operativos da política econômica global e finalmente considerar o planejamento como um processo político-social.

Valendo-se das experiências no ordenamento territorial das metrópoles latino-americana, Parisi (1972:213) constata que

La extensión encontrada de las zonas urbanas por su parte trae nuevos problemas en lo que toca a medios de transporte y a los equipos urbanos básicos, como el sistema de alcantarillado y agua potable, y a los servicios de salud y de educación. La limitación de los instrumentos jurídicos disponibles en América Latina para un control social más estricto sobre el uso de la tierra lleva a una extensión indefinida de la superficie ocupada por las ciudades y se produce asi una disminución de las densidades demográficas. De tal modo, se anular las ventajas que la concentración urbana puede significar en la disminución de los costos por habitante de los medios de transporte y de los equipos y servicios urbanos y es casi imposible para las municipalidades, aun con la ayada del poder central, hacer frente a las inversiones exigidas para por lo menos mantener una cierta equivalencia en las condiciones de vida urbana. Por otra parle las distancias excesivas que hay que recorrer diariamente llevan a un desgaste que afecta a parte significativa de las poblaciones urbanas. Los gobiernos se han visto entonces obligados a procurar la solución de este problema del transporte diario por medio de sistemas en general bastante

\footnotetext{
29 O Seminário Internacional sobre El Processo de Metropolización em Chile y América Latina promovido pelo ILDIS - Instituto Latino Americano de Investigaciones Sociales foi organizado pelo Departamento de Estudos e Planejamento Urbano - Regional (DEPUR) da Faculdade de Arquitetura e Urbanismo da Universidade do Chile e copatrocinado pela Oficina de Planejamento Nacional (ODEPLAN), se realizou em Santiago do Chile de 12 a 16 de junho de 1972.
}

[Digite texto] 
costosos en términos de inversión, como es el caso, por ejemplo de los transportes subterráneos. En São Paulo y Rio de Janeiro, por ejemplo se ha calculado el costo de cada kilómetro de línea en 10 millones de dólares. ${ }^{30}$

Para se entender a metrópole, naquele momento, seria necessário partir de concepções de uma estrutura econômica, ideológica, jurídico-política complexas, expressas espacialmente na dinâmica das relações sociais estabelecidas ao longo do processo histórico-geográfico. As metrópoles latinoamericanas deveriam ser concebidas no contexto do crescimento e reprodução do sistema capitalista entre países de maior e de menor desenvolvimento relativo, na categoria analítica de centro-periferia, para examinar as relações entre América Latina e as economias industrializadas.

A expansão das relações capitalistas nos países latino-americanos se inseriria numa ordem de divisão internacional do trabalho que, para os observadores dos países periféricos, contrastaria com a imagem de caos e desordem de seus próprios espaços nacionais. Diante do crescimento rápido e desordenado dos aglomerados urbanos e das regiões, os países da América Latina não têm elaborado uma política que supere os estreitos limites do planejamento físico e do urbanismo tradicionais e a realidade da explosão demográfica com taxas elevadas de urbanização, todos os fenômenos que ocorreriam no marco de uma desarticulação territorial (o clássico dualismo costa-hinterlândia) e de uma constelação de cidades que pela sua localização e sua magnitude relativas não permitiriam discernir estrutura hierárquicofuncional coerente.

\footnotetext{
30 - A extensão encontrada das zonas urbanas por sua vez, traz novos problemas no que toca os meios de transportes e os equipamentos urbanos básicos, como o sistema de rede de esgoto e água potável, e os serviços de saúde e de educação. A limitação dos instrumentos jurídicos disponíveis na América Latina para um controle social mais estrito sobre o uso da terra leva a uma extensão indefinida da superfície ocupada pelas cidades e se produz assim uma diminuição das densidades demográficas. Assim, se anular as vantagens que a concentração urbana pode significar na diminuição dos custos por habitante dos meios de transportes e dos equipamentos e serviços urbanos é quase impossível para os municípios, mesmo com a ajuda do poder central, fazer frente às intervenções exigidas para pelo menos manter certa equivalência nas condições de vida urbana. Por outro lado, as distâncias excessivas que têm que recorrer diariamente chega a um desgaste que afeta a parte significativa das populações urbanas. Os governos se têm visto então obrigados a procurar a solução deste problema de transporte diário por meio de sistemas em geral bastante custosos em termos de intervenção, como é o caso, por exemplo: dos transportes subterrâneos. Em São Paulo e Rio de Janeiro, por exemplo: se tem calculado o custo de cada quilômetro de linha em 10 milhões de dólares.
}

[Digite texto] 
As aglomerações urbanas latino-americanas apresentariam, em sua grande maioria, características de uma urbanização semiparasitária que não se sustentariam em vigorosos processos de industrialização e modernização que de certo modo acabariam por frear, anulando, através das deseconomias de aglomeração, todos os benefícios das economias externas e de escala. Embora a ênfase desta ineficiência se atenha inicialmente ao efeito da degradação do meio ambiente urbano, levaria à incapacidade do processo produtivo de gerar um meio de trabalho ou condições materiais para a produção de condições para a vida humana adequadas, especialmente nas grandes aglomerações urbanas.

Segundo Basten (1972: 37), a noção de metrópole corresponde a uma cidade excepcionalmente grande, seja pela população aglomerada que se conta em centenas de milhares de habitantes, seja pela sua área continuamente urbanizada que se mede em quilômetro quadrado, seja pela importância das regiões e cidades que se encontram sob seu comando econômico. A metrópole é normalmente uma cidade-região a partir de um núcleo principal e, graças aos recursos da sociedade industrial, induz à rápida urbanização das áreas vizinhas, anexando antigos núcleos, integrando-os na nova realidade sócio-econômica e deixando superpostas as unidades políticoadministrativas que thes correspondiam.

As regiões metropolitanas, aglomerações urbanas e microrregiões, denominadas de novos arranjos territoriais foram se formando a partir da intensificação da industrialização no país e de embates políticos imobilizantes, impedindo a realização de uma reforma agrária distributivista de terras no país. Os fluxos migratórios se intensificaram em direção aos centros urbanos, muitas vezes ultrapassando os limites territoriais das unidades político-administrativas locais. Esses novos arranjos territoriais, como um conjunto de várias jurisdições político-territoriais contíguas e superpostas abrangeria Estados e municípios com elevada densidade demográfica.

Por sua vez, as instituições, a estrutura física e administrativa se apresentariam ineficazes diante da crescente pressão em ordenar territorialmente o processo acelerado de expansão dos grandes centros. $O$ resultado do despreparo institucional e estrutural das metrópoles para receber um grande contingente aceleradamente foi a escassez de serviços públicos, 
deficiente número e qualidade de habitações, problemas de segurança e degradação ambiental, perda das externalidades positivas, entre outras. Essas questões relacionam-se ao disciplinamento da ocupação, uso e domínio do solo urbano que necessariamente incluiria esses novos arranjos territoriais na perspectiva do ordenamento territorial.

De forma controversa, os conflitos de interesses que se estabelecem entre o bem-estar da população e a infraestrutura implantada pelo governo para atrair as empresas, direta ou indiretamente têm seus custos transferidos à população. O custo de vida da população das grandes aglomerações urbanas se eleva, ao passo dos elevados custos de implantação de uma infraestrutura urbana: saneamento, habitação, hospital, escola, etc.; e o gerir grandes espaços urbanos, necessita de um aporte de planejamento urbano do governo capaz de gerar políticas de expansão equilibrada, atenuando as disparidades regionais e assegurando o bem-estar coletivo.

Desde a década de 1950, no Brasil, a realidade metropolitana e aglomerações urbanas vêm chamando atenção da sociedade e das autoridades e indicando a necessidade de reformas políticas, fiscal, tributária e institucional para esses denominados novos arranjos territoriais. Estudos desenvolvidos pelo IBGE nos anos 50 e 60 indicavam a necessidade de urgentes mudanças nos paradigmas do planejamento. $O$ planejamento regional, inspirado na experiência norte-americana, deveria ser complementado por um instrumento como o orçamento plurianual, para garantir o plano e projetos.

Ao longo do período autoritário no país, as estruturas criadas eram completamente prefixadas e hierárquicas, de alto controle por parte do poder executivo e de características técnicas e funcionais, em contraposição, aos desejáveis meios participativos dos municípios constituintes das regiões metropolitanas e de suas representações políticas. As regiões metropolitanas tinham seus conselhos deliberativos que eram presididos e tinham a maioria de seus membros indicada pelo Executivo Estadual, que por sua vez era indicado pelo Executivo Federal. Os conselhos consultivos, onde os municípios estariam representados, não tinham nenhum poder decisório, restringindo-se apenas a apresentar sugestões. 
A estrutura metropolitana então criada nesse período completava o modelo de estruturação de fundos federais que financiavam o desenvolvimento urbano, sobretudo saneamento, habitação e transportes, e que canalizavam os recursos diretamente para as companhias estatais encarregadas da implementação das políticas, com pouco ou nenhum vínculo de subordinação às próprias políticas de planejamento urbano e regional elaboradas pelos órgãos metropolitanos. Assim, na época, as cooperativas habitacionais ou estatais de saneamento definiram muito mais os eixos de expansão metropolitana do que os planos metropolitanos elaborados no período.

O planejamento para o desenvolvimento urbano foi marcado pela institucionalização do planejamento nas três esferas do governo após o Decreto Lei No 200 de $1967^{31}$, que definiu como instrumentos básicos do planejamento: plano geral de governo; programas gerais, setoriais e regionais, de duração plurianual; orçamento-programa anual e programação financeira de desembolso. Embora incipiente, o planejamento passou a ser um princípio fundamental da administração pública visando à criação de órgãos responsáveis pelo crescimento e desenvolvimento do país.

Segundo Bezzon (2003:10), o planejamento no Brasil, à época, ainda não era reconhecido no Brasil como um "processo básico de governo". Nos países de economia mais avançada, a prática do planejamento usada em larga escala, como já citados alguns exemplos nesse trabalho, viabilizava ações e intervenções racionais e ordenadas do Estado no domínio econômico, sendo estes de regime político socialista ou capitalista. Não havia ao nível federal, de forma institucional, órgão algum ou agência nacional responsável pelo planejamento e pesquisa para o desenvolvimento global do país, à exceção do Instituto Brasileiro de Geografia e Estatística - IBGE.

Há exemplo de outros países, como Estados Unidos, Inglaterra e França, que já aplicavam o planejamento de âmbito regional ou mesmo nacional, considerando este, como, do ponto de vista global, e denominado de

\footnotetext{
${ }^{31}$ No governo de Castelo Branco, o Decreto-Lei No 200 de 1967 dentre outras inovações, organizou o orçamento público e instituiu a delegação de autoridade, a coordenação e o controle na administração pública. O Decreto promoveu a descentralização administrativa a expansão da administração indireta (sociedades de economia mista, empresas públicas, fundações e autarquias), favorecendo também o desenvolvimento de uma tecnoburocracia qualificada, coexistente com o núcleo tradicional da administração direta.
}

[Digite texto] 
"comprehensive planning". No Brasil os planos nacionais ou regionais formulados como 0 Plano Salte - Saúde, Alimentação, Transporte e Energia, e o da SPVEA - Superintendência do Plano de Valorização Econômica da Amazônia, entre outros, foram considerados "esquemas para distribuição de verbas orçamentárias, faltandoIhes a consciência, as características e a amplitude do verdadeiro planejamento, pois neles não se integrariam os diferentes elementos do "comprehensive planning". ${ }^{2}$

A década de 70 , no Brasil, é caracterizada por forte concentração urbana, em que a migração campo-cidade se acentuou devido ao grande desenvolvimento industrial decorrente do período do "milagre econômico" brasileiro, de 1967 a 1973. Naquela época se consolidaram os processos de metropolização das cidades das principais capitais do país, principalmente das regiões sudeste e sul. $O$ crescimento urbano das cidades brasileiras a extensões quase imensuráveis gerou os maiores problemas urbanos e sociais, sendo os recursos disponíveis insuficientes, o que significou maior demanda por habitações, saúde, educação, serviços básicos como abastecimento de água e coleta de esgotos, transportes entre outros.

O agravante da crise do petróleo em 1973 abalou a situação econômica brasileira, demandando maior importação de produtos industrializados para suprir as necessidades de consumo internas, e a investir cada vez mais na infraestrutura produtiva do país. A dívida externa se acentuou e reduziram-se os investimentos públicos e privados no país, desencadeando o processo inflacionário e levando o governo a adotar medidas urgentes de contenção dos gastos públicos e a partir dos cortes nos investimentos, as obras de infraestrutura urbana foram atingidas, agravando as condições de vida das populações, principalmente as das grandes cidades.

A década de 1970 ficou marcada pela introdução de uma política de desenvolvimento urbano no sistema de planejamento nacional no âmbito do processo de desenvolvimento nacional que se baseava na concepção de que a geração, difusão e adaptação de inovações se processariam ao longo do tempo em determinados pontos do território (modelo dos pólos de

\footnotetext{
32 Modesto, H.;Mello, Diogo Lordelo de. In Mentalidade de Planejamento no Brasil - IBAM - 1965.
}

[Digite texto] 
desenvolvimento de Michel Rochefort); principalmente nas aglomerações urbanas, valendo-se das diferenças locais baseadas na capacidade de gerar, aplicar e irradiar as inovações pelo território, com que geraria outros pólos, sucessivamente.

O ordenamento territorial seria baseado no processo contínuo de equilíbrio e desequilíbrio dos pólos de desenvolvimento e o planejamento integrado das metrópoles e aglomerações urbanas, em função dos problemas gerados pela descontrolada urbanização, inseria-se no mesmo contexto de processo instrumental para o desenvolvimento.

A crise fiscal e a redemocratização do país nos anos de 1980 abalaram o modelo de gestão e os órgãos responsáveis pelo ordenamento territorial metropolitano pela drástica redução de recursos aos órgãos federais que atuavam no desenvolvimento urbano, atingindo os investimentos até serem extintos juntamente com as estatais de serviços urbanos. Concomitante à crise e suas consequências negativas ao planejamento metropolitano, a redemocratização do país permitiu que outros atores sociais entrassem em cena juntamente com os governos locais oriundos do processo de descentralização cujas demandas não contemplavam perspectivas metropolitanas no país.

Como já referido, a Constituição Federal de 1988 foi elaborada num contexto de descentralização com o fortalecimento do papel dos municípios nesse processo. Nos países em processo de (re) democratização como era a situação da maioria dos países latino-americanos, o processo de descentralização passou a ser concebido como uma dimensão fundamental para superar ou se antepor ao regime autoritário precedente. As instituições financeiras mundiais foram importantes agentes difusores, em escala global, de processos descentralizadores. Essa tendência de descentralização do poder e de aumento da autonomia municipal contribuíram para a não-legitimidade e representatividade das regiões metropolitanas, assim como para o seu esvaziamento ou até extinção com o tempo.

Como saída à gestão territorial, mais recentemente foram incentivados os consórcios entre municípios para enfrentar os limites das determinações político-administrativas territoriais do nosso país cujos espaços econômicos são marcadamente regionais, e não apenas municipais. Portanto, a gestão [Digite texto] 
metropolitana não se enquadrava nas regras do federalismo e do processo de descentralização explícitos na última constituição federal.

Ordenar territorialmente a realidade das metrópoles, no Brasil como no mundo vem se tornando uma das mais desafiantes preocupações de instituições internacionais, entidades supranacionais, ministérios e governos, preocupados em administrá-las na própria complexidade em que se constituem. Diante de uma realidade metropolitana que imporia uma concepção do ordenamento territorial em bases regionais, a forma como se apresenta o federalismo brasileiro e como se estabelecem as relações intergovernamentais inviabilizam o planejamento regional efetivo e impõe urgentes reformas institucionais no país.

As metrópoles e aglomerações urbanas brasileiras são arranjos territoriais resultantes do processo acelerado de urbanização, sem o devido planejamento e controle, somando numeráveis problemas decorrentes de sua expansão e consolidação e domínio de seus territórios. Metrópoles e aglomerações urbanas abrangem municípios e Estados de diferentes características constitutivas e que impõem uma nova forma de pensar 0 território e novas formas de administração e gestão públicas, que vão além do que a constituição federal estabelece nas relações entre os níveis de governo quanto à transferência de recursos e de atribuições a cada nível de governo quanto ao ordenamento de seus respectivos territórios. Metrópoles, aglomerações urbanas e microrregiões tornaram-se desafios ao ordenamento territorial urbano.

A realidade metropolitana e a importância da institucionalização urgente de instrumentos adequados das regiões metropolitanas no país, com base na expansão acelerada dos aglomerados metropolitanos, exigiriam disciplina e direção planejada com o objetivo de desestimulá-la ou ordená-la, buscando alcançar uma forma equilibrada de expansão e desenvolvimento que repouse sobre o fortalecimento de sua base econômica e dos serviços e equipamentos principais, tanto quanto sobre seu ordenamento espacial (Caffé, 1981).

Entretanto, por recobrirem espacialmente e simultaneamente vários territórios municipais, tais problemas se agravam, não mais podem figurar apenas no âmbito de atuação administrativa da autoridade local e não oferecem condições para ser objeto de planejamento adequado nesse âmbito. 
Daí a necessidade da institucionalização do planejamento metropolitano e a exigência da criação de administrações metropolitanas ou mesmo de governos de âmbito urbano-regional.

As relações intergovernamentais que se desenvolvem impõem um novo espaço institucional metropolitano ainda não legitimado e "ameaçador" à ordem federalista no país. A base federalista brasileira não se adéqua aos novos arranjos territoriais de metrópoles e aglomerações urbanas, e as limitações institucionais se deparam com esvaziamento do papel político dos Estados e o aumento do papel político dos municípios no ordenamento de seus territórios.

O ordenamento territorial urbano não se resumiria a uma repartição igualitária de recursos, nem o planejamento urbano se limitaria ao zoneamento do uso do solo. Diante das metrópoles e aglomerações urbanas, tornou-se difícil pensar a oferta de bens e serviços públicos independente das questões que a envolvem. A horizontalização dessas questões e as especificidades locais modificam as exigências de cooperação entre os atores políticos envolvidos e desencadeia novas reivindicações institucionais direcionadas aos novos arranjos territoriais.

Diante dos grandes centros, metrópoles e aglomerações urbanas, as políticas nacionais de ordenamento do território refletidas no âmbito regional e local seguiriam outra lógica, que visaria de fato reduzir os custos de equipamento e funcionamento dos grandes serviços públicos de administração, de transporte e de comunicação e permitiriam o acesso às condições necessárias de qualidades de vida de seus habitantes.

Então, a disposição dos equipamentos e serviços públicos adquiriria uma visão regional e sofreria uma reorientação. Tal realidade metropolitana imporia uma reestruturação das relações verticalizadas e horizontalizadas do governo a partir da visão de conjunto entre ministérios e órgãos que atuariam integrados setorialmente sobre o território, e convergiriam às intervenções em direção aos objetivos regionais.

Pretende-se reconhecer que uma das principais preocupações do ordenamento territorial urbano imposta aos governos locais consistiria em limitar a expansão das metrópoles e aglomerações urbanas ou reordenar o seu crescimento. As metrópoles tornaram-se desafios às administrações locais e muito complexas as políticas de ordenamento territorial urbano e de elevado [Digite texto] 
custo à sociedade. Gerir esses novos arranjos territoriais aponta a uma nova percepção e concepção de planejamento no ordenamento territorial urbano assim como impõe urgentes reformas jurídica, institucional e administrativa. 


\subsection{Capítulo 7 - Requisitos para o planejamento governamental: desafios lançados ao desenvolvimento territorial}

O planejamento governamental está em crise. A atual crise do planejamento está associada à crise do papel político do governo e à ausência de um projeto político de desenvolvimento da nação ou, em outras palavras, de um projeto de país com objetivos claros, de médios e longos prazos a serem seguidos pelo governo e pela sociedade visando o desenvolvimento nacional e a reinserção da economia brasileira no ordenamento econômico mundial, segundo o economista Sr. Reis Velloso, ex-ministro do planejamento, em entrevista (Anexo A). Acrescenta-se a esse quadro a fragilidade dos instrumentos institucionais, a ausência de conscientização e de apoio político da sociedade à importância do planejamento para as ações do governo e em benefício de toda a sociedade no processo de desenvolvimento do país.

O ideário do planejamento governamental esteve por pelo menos duas décadas associado ao autoritarismo do regime militar que correspondeu ao auge do planejamento no país, marcado pela visão tecnocrática, pela centralização de decisões e desarticulação das políticas setoriais. $O$ atual modelo de planejamento, resquício de um modelo centralizador e autoritário dos anos 60 e 70, é visto pela sociedade e pela classe política como algo inócuo, improdutivo e sem sentido e, por ser um tema de antemão marginalizado nos atuais debates, poucos avanços ocorrem numa possível proposta de remodelar o planejamento governamental de médios e longos prazos.

A Constituição Federal de 1988 introduziu alterações no perfil do federalismo brasileiro a partir da transferência de recursos e encargos entre as instâncias do governo. O processo de descentralização lançou o ordenamento territorial aos Estados e municípios e incitou o planejamento governamental em todos os níveis de governo. Todos os níveis de governo, pelo menos em tese, devem dispor de instrumentos e de órgãos capazes de proporcionar condições financeiras, humanas, técnicas e administrativas favoráveis ao planejamento do desenvolvimento territorial.

Como visto, o processo de redemocratização e descentralização impôs novas percepções e concepções ao planejamento do desenvolvimento 
territorial com base nos novos arranjos territoriais, agregando interesses de novos atores e incitando novos pactos territoriais, assim como reformas jurídicas, institucionais e administrativas. A perda do poder de instrumentalização sobre o território e de barganha com Estados e municípios pelas dificuldades financeiras fez com que o governo federal reforçasse 0 controle sobre os níveis de governo no processo de descentralização, ao adotar medidas restritivas de ajuste fiscal com a $L^{2} F^{33}$.

Combater os desequilíbrios fiscais dos Estados e municípios é de fundamental importância para federações como é o caso do Brasil, que por tanto anos teve planos e programas interrompidos pelas graves crises e desestabilidades das finanças públicas. Isso se explica pelo fato de os governos subnacionais desempenharem papel importante para o alcance das metas, a partir da implementação de programas e projetos. Cada vez mais, medidas coercitivas de ajuste fiscal do governo se justificam pelo elevado nível de descentralização, pela redução das manobras financeiras intergovernamentais e pela redução do poder de manobra do governo federal sobre as finanças públicas.

Em outras palavras, para que o planejamento se instaure nos níveis de governo, tornou-se imprescindível o ordenamento das finanças públicas baseado numa gestão fiscal transparente e participativa, endividamento ajustado aos limites legalmente estabelecidos, contas planejadas por meio do uso efetivo dos instrumentos existentes (plano plurianual e lei orçamentária), prestação de contas dos gestores públicos e extinção das práticas predatórias entre os entes federativos. As estabilidades financeira, monetária e orçamentária contribuiriam para a prática do planejamento governamental.

Do ponto de vista do desenvolvimento regional, as medidas coercitivas de controle fiscal do governo e de autonomia tributária reforçam a dependência de Estados e municípios aos repasses do governo central, e restringem as relações financeiras entre governos com perdas expressivas da perspectiva regional. A grande extensão territorial, a expressiva diversidade regional e os

\footnotetext{
${ }^{33}$ A LRF- Lei de Responsabilidade Fiscal objetiva uma administração mais equilibrada e transparente dos recursos públicos. Os governantes dos Poderes Executivo, Legislativo e Judiciário, além do Ministério Público e das três esferas de governo, passam a ter compromisso com orçamentos e metas, de modo a evitar o descontrole dos gastos sem o devido conhecimento da União.
}

[Digite texto] 
desequilíbrios no federalismo incentivam uma competição tributária vertical e horizontal entre os níveis de governo a ponto de produzir as chamadas "guerras fiscais" entre Estados e até municípios das regiões metropolitanas. $\mathrm{O}$ equilíbrio fiscal passou a ser prioridade do governo, delimitando medidas favoráveis ao retorno do planejamento regional no país nos moldes vigentes até a década de 90 .

A concepção do planejamento governamental, como estratégia de desenvolvimento do país, nunca deixou de existir, mesmo após o fim do período da ditadura militar. A capacidade de elaborar planos de desenvolvimento para o país foi substituída pela elaboração de mecanismos de ajuste fiscal do governo. Os PND's foram praticamente substituídos pelos planos plurianuais, de bases regionais, sobre um sistema municipalizado de políticas públicas que pretende num determinado intervalo de tempo, que o governo tenha claramente em suas ações e intervenções, os objetivos a serem alcançados em busca do crescimento e desenvolvimento do país. Aportes informativos são necessários para a análise e conhecimento da situação que se apresenta, a fim de que decisões sejam tomadas em todos os níveis do governo de modo integrado, simultâneo e sistemático dentro de uma previsibilidade orçamentária e de resultados.

Outro requisito a considerar no planejamento governamental seria 0 mínimo de conhecimento, capaz de permitir que a atuação sobre uma determinada realidade, produza os resultados propostos. Estudos de todos os gêneros que contribuem para o conhecimento de uma determinada realidade são indispensáveis ao planejamento. É preciso organizar, catalogar e sistematizar dados e elementos envolvidos em nossa ação de forma a não só possibilitar a obtenção de resultados satisfatórios como sua futura avaliação. Avaliar resultados seria ato de rotina, corrente instrumento de trabalho $e$ indispensável aos profissionais e técnicos que se habilitam à prática do planejamento.

Entre as etapas do planejamento governamental, devem constar basicamente o diagnóstico e o prognóstico da situação, a definição dos objetivos, a elaboração dos planos e metas, os meios de implementação, avaliação e controle dos resultados, de modo que permitam uma contínua retroalimentação do processo em qualquer etapa e que todas se apresentem [Digite texto] 
susceptíveis ao acréscimo de novos dados, informações que permitam a "renovação" sistemática do processo.

Faz-se necessário reconhecer que o sistema de planejamento governamental surgido no país na década de 1960, baseado num Projeto de Brasil, necessita de reformulações, assim como o país necessita de um projeto de desenvolvimento da nação. Após o processo de democratização e descentralização, Estados e municípios assumiram importante papel nas políticas de ordenamento territorial necessitando, portanto, de reformas no plano político, financeiro, institucional e científico que sejam os aportes para o retorno do planejamento em prol da funcionalidade do território e do bem-estar da população. 


\section{PARTE 2 - O RIO DE JANEIRO À LUZ DO ORDENAMENTO TERRITORIAL URBANO NO PLANEJAMENTO GOVERNAMENTAL}

\subsection{Capítulo 1 Pontos e contrapontos do ordenamento territorial urbano da metrópole do Rio de Janeiro: subsídios para uma avaliação}

O presente capítulo tem por objetivo a análise do ordenamento territorial urbano no Rio de Janeiro. A análise do ordenamento territorial urbano de uma metrópole como o Rio de Janeiro torna-se um tema relevante a pesquisadores, técnicos, profissionais e políticos ligados ao planejamento urbano e regional que se deparam com uma realidade complexa, de difícil manejo para estabelecer políticas de ordenamento de seu território.

Desde o início de sua ocupação, apropriação, expropriação e expansão, a cidade do Rio de Janeiro apresentou muitas dificuldades em transpor os obstáculos naturais e as condições hostis que impôs intensas intervenções do governo sobre o espaço em construção a fim de criar condições habitáveis e susceptíveis à instalação de uma infraestrutura urbana.

A ausência de estrutura de planejamento urbano e regional e as intervenções localizadas de elevado custo resultaram num espaço bastante segmentado de bairros com infraestrutura e serviços de custos elevados próximos de outros bairros sem qualquer investimento, deficientemente articulados entre si o que permitiu uma justaposição social determinante dos conflitos sociais e territoriais de difícil elaboração de políticas de ordenamento do território.

O território da cidade do Rio de Janeiro, outrora Distrito Federal e Estado da Guanabara, consolidou-se num dos espaços mais segregados e desarticulados, inclusive com a área de influência direta composta por municípios limítrofes que compõem sua respectiva região metropolitana no contexto de ausência de uma autêntica estrutura de planejamento urbano e regional e reforçada pelo déficit institucional.

Ao longo de sua história, a estruturação do espaço do Rio de Janeiro, enquanto unidade federativa resultou num dos espaços mais contraditórios e [Digite texto] 
de acentuadas disparidades internas entre a capital e o Estado do Rio de Janeiro. Tanto a capital quanto o Estado do Rio de Janeiro, ambos se estruturaram, de modo desarticulado um do outro, do ponto de vista físicoterritorial, político, econômico, institucional e administrativo a ponto de resultar em duas realidades distintas, desequilibradamente constituídas e com sérios efeitos nas políticas de ordenamento de seus territórios.

Ao longo da estruturação do espaço do Rio de Janeiro, as políticas de ordenamento territorial estiveram voltadas para duas perspectivas: a primeira em direção às políticas de ordenamento que reforçaram a centralidade da cidade do Rio de Janeiro e a segunda em direção à projeção metropolitana com significantes manobras políticas e financeiras para atrair empresas estratégicas do ponto de vista do desenvolvimento nacional entre outros investimentos, mas que de fato não contribuíram para os necessários avanços institucionais metropolitanos, nem tampouco para maior articulação da capital com o interior.

A estruturação da metrópole do Rio de Janeiro tem no papel do Estado, no campo econômico, o de garantir ao máximo a reprodução do capital, fazendo concessões apenas quando estas se evidenciam necessárias, ou seja, para assegurar as condições mínimas de reprodução da força de trabalho (estabilidade social). O modelo metropolitano do Rio de Janeiro tende a ser o de uma metrópole de núcleo hipertrofiado, concentrador da maior parte da renda e dos recursos urbanísticos disponíveis, cercado por estratos urbanos periféricos cada vez mais carentes de serviços e de infraestrutura à medida que se afastam do núcleo, e servindo de moradia e de local de exercício de algumas outras atividades às grandes massas de população de baixa renda (Abreu, 2006).

Os interesses especulativos que direcionaram o crescimento da cidade do Rio de Janeiro e o tratamento inconsistente e casuístico dos fatos urbanos foram gerando inúmeros e maiores problemas urbanos, sociais e ambientais, como degradação ambiental, formação de bolsões de miséria, ocupações desordenadas do solo, inadequação e insuficiência dos equipamentos coletivos, produção de espaços ilegais, favelização, verticalização, vazios urbanos que foram se agravando pela ausência de uma estrutura de planejamento e de recursos a fim de atender a crescente demanda por [Digite texto] 
habitação, saúde, educação, serviços básicos como abastecimento de água e coleta de esgotos, transportes, entre outros.

Desde os primeiros anos de ocupação, a cidade do Rio de Janeiro apresentou uma complexa situação jurídica de posse, domínio, uso e propriedade do solo que impedia os avanços institucionais e as políticas de ordenamento territorial urbano. Ao passar dos anos, verificamos que os mesmos problemas persistem resultando no quadro de heterogeneidades de condições fundiárias reforçado pelas relações sociais, à margem do que se considera como legal. Ao longo do tempo o arcabouço legislativo e normativo, planos e programas de ordenamento territorial urbano elaborados tornaram-se ineficazes ou anacrônicos.

As políticas de ordenamento territorial, atualmente direcionadas ao município do Rio de Janeiro, sofreram influências diretas da própria condição político-administrativa e institucional que a cidade do Rio de Janeiro assumiu ao longo de sua história, que contribuíram para reafirmar uma posição políticoregional atípica em relação às demais capitais dos grandes Estados; e das relações políticas estabelecidas entre os representantes políticos locais e regionais e os representantes políticos das demais esferas do governo.

A estruturação do espaço urbano carioca caracterizou-se por intensos conflitos oriundos da complexa estrutura interna de poderes sobrepostos, pelo conjunto de legislação e normas urbanísticas excludentes e ineficazes às questões de justiça social, pela intensa presença do governo federal nas decisões políticas locais, pela ineficiente estrutura organizativa e administrativa dos órgãos de planejamento do governo, pelo distanciamento dos planos e programas da realidade dinâmica das relações sociais estabelecidas e principalmente pela descontinuidade das ações e políticas urbanas.

Os instrumentos urbanísticos estabelecidos enfatizavam o ordenamento físico-territorial e a definição de usos e parâmetros edilícios corroborando a lógica elitista em detrimento das peculiaridades das relações sociais. A apropriação desigual da terra urbana, o déficit habitacional e de infraestrutura de bens e serviços urbanos e os impactos ambientais foram se agravando ao longo dos anos. O planejamento da cidade, baseado no desenvolvimento urbano e econômico, privilegiava a lógica do espaço construído direcionada pelo mercado e o controle social desse referido território. 
A priori, as políticas de ordenamento territorial no Rio de Janeiro, enquanto capital de uma das mais expressivas regiões metropolitanas do país, foram direcionadas à descentralização e controle do processo de urbanização concentrada, sobretudo em reduzir a pressão sobre o solo urbano. Em contraposição à apropriação privada predominante na estruturação do espaço urbano carioca, o ideário do ordenamento territorial imporia uma revisão das leis e normas urbanísticas que regem a ocupação, apropriação, expropriação e do domínio do solo urbano no contexto do planejamento urbano e regional em busca de maior socialização do referido espaço. No entanto, o arcabouço legislativo e normativo urbanístico tornou-se complexo, fragmentário e disperso, numa realidade espacial construída ao longo dos anos sem uma estrutura autêntica e adequada de planejamento e com graves problemas de infraestrutura, de habitação e de acesso aos bens e serviços públicos pela população.

O município do Rio de Janeiro adotou uma posição diferente das demais capitais das regiões metropolitanas. Os governos locais se direcionaram para as políticas de urbanização de seu território reforçando os limites políticoadministrativos em detrimento de políticas públicas de maior alcance territorial, susceptíveis ao ordenamento territorial de sua região metropolitana. Outros agravantes, como o esvaziamento de recursos e de órgãos de planejamento do governo estadual, enfraqueceram toda a perspectiva de planejamento metropolitano e as incompatibilidades político-partidárias, entre os representantes dos cargos públicos das esferas do governo, entre outros, resultaram nas descontinuidades dos programas e projetos, pondo fim aos propósitos do ordenamento de seu território.

Após a fusão dos Estados do Rio de Janeiro e Guanabara em 1975, o novo município do Rio de Janeiro, capital do Estado, foi objeto de minucioso levantamento de informações voltado à realização do PUB-RIO-Plano Urbanístico Básico. Naquela ocasião, o planejamento de um território urbano considerável ditou a necessidade de sua subdivisão em áreas de planejamento (AP's), e na década seguinte foram realizados estudos que definiram a delimitação das chamadas regiões administrativas. Tais metodologias para 0 planejamento da cidade continuam presentes e servem de base para a administração pública local. 
A capital do Estado do Rio de Janeiro, também denominada cidade do Rio de Janeiro, adquiriu diferentes funções econômicas e assumiu diferentes posições político-administrativas, ao longo de sua história, determinantes na elaboração das políticas de ordenamento de seu território, que privilegiaram o caráter nacional e local em detrimento dos aspectos regionais de restrito desenvolvimento do ponto de vista institucional. A configuração dicotômica do Rio de Janeiro, entre capital e interior, resultou de políticas de ordenamento territorial urbano como a construção de ferrovias e rodovias, mecanismos de atrair indústrias e serviços entre outras concentradas na capital do Estado. Atribuímos a perda do status de centralidade da cidade para outros municípios e Estados à fragilidade política e institucional do planejamento urbano e regional à luz do ordenamento territorial ao longo de sua história.

$\mathrm{O}$ ordenamento territorial na cidade do Rio de Janeiro reforçou a superposição de órgãos do governo federal e estadual numa suposta política de integração entre as esferas do governo. A cidade tornou-se alvo de intensas intervenções do governo federal, sobretudo nas construções das principais vias de acesso à cidade e às políticas de habitação para a população de baixa renda, na questão do saneamento urbano e no controle dos fluxos migratórios para a capital da região metropolitana do Rio de Janeiro, mas, reconhecidamente de poucos resultados eficazes.

A superposição de órgãos do governo federal, do Estado e o do município, nos projetos e programas urbanísticos recai na própria indefinição das competências das esferas do governo e desencadeia conflitos de ordem político-partidária com sérias interrupções das ações públicas no ordenamento do território e o agravamento das condições sociais, infraestruturais e ambientais.

As políticas de ordenamento territorial da cidade do Rio de Janeiro tornaram-se sinônimo de intensos conflitos políticos expressos territorialmente no processo de ocupação, apropriação, expropriação e expansão do espaço urbano. Impasses institucionais, descontinuidade das ações públicas, deficiências administrativas públicas e a ausência de integração dos órgãos de planejamento do governo impedem maiores avanços na perspectiva regional do espaço em questão e corroboram o quadro de decadência dos bens e serviços públicos e da qualidade de vida da população. 
Atualmente, o ordenamento territorial da cidade do Rio de Janeiro sofre influências diretas de se tornar uma das sedes dos eventos mundiais da Copa do Mundo em 2014 e das Olimpíadas em 2016 que estão por vir, impondo uma lógica de intervenções urbanas localizadas que se sobrepõe aos instrumentos de planejamento urbano a fim de atrair investimentos que desencadeiam numerosos conflitos sociais e territoriais.

A ausência de um projeto único de cidade, a deficiente estrutura de planejamento e os apelos imediatistas do governo para atrair recursos no contexto de um oportunismo quanto aos eventos que estão por vir, favorecem os interesses de determinados grupos e reforçam a configuração territorial segmentada e os graves problemas urbanos.

Ao longo dos anos, o ordenamento territorial urbano do Rio de Janeiro, como técnica administrativa, ação política eminentemente pública e científica, na própria complexidade de conciliar conflitos políticos de diversos atores, foi aos poucos reduzido à imposição dos interesses dos grupos sociais mais influentes no contexto de uma geopolítica maior, com significativa restrição da participação da sociedade nas decisões políticas. Os resultados das políticas de ordenamento territorial reforçam o quadro de despreparo político, administrativo, econômico, cultural, ambiental e social do governo em lidar com as novas propostas de ordenar o território.

O ordenamento territorial da cidade do Rio de Janeiro sempre esteve atrelado ao papel político que a referida cidade assumia no âmbito das políticas nacionais, envolto em intensos conflitos de interesses na maioria das vezes prejudiciais ao seu próprio desenvolvimento. Territorialmente, a cidade do Rio de Janeiro se constituiu de modo muito voltado para as relações exteriores e/ou para as ações e intervenções locais, sem maiores avanços na questão regional. Ao longo de sua história a cidade tornou-se refém da sobreposição de poderes e disputas políticas que dificultavam seu ordenamento territorial.

As dificuldades de ocupação do sítio e as funções atribuídas à cidade do Rio de Janeiro, os recursos disponíveis provenientes de sua condição políticoadministrativa ao longo de sua história, conduziram as ações e intervenções locais elitistas e legitimadas por leis e normas urbanísticas que se deparavam com situações fundiárias escusas, sem uma estrutura de planejamento integrado adequada, resultando num espaço segmentado socialmente e pouco 
articulado e pouco integrado fisicamente e de difícil manejo no ordenamento de seu território. O espaço urbano em questão é o resultado de sobreposições das ações e intervenções do governo ao longo do tempo, sem a devida estrutura de planejamento e de elevado custo para a sociedade.

A ação e intervenção do governo foram fundamentais na expansão e ocupação da metrópole do Rio de Janeiro, embora num desordenado processo sem planejamento, expandindo a rede ferroviária e rodoviária aos subúrbios, sem o devido acompanhamento de obras de saneamento e infraestrutura. Normas e leis urbanísticas sofreram inúmeras modificações de seus conteúdos a partir de emendas favorecedoras das práticas especulativas pelo setor imobiliário. A questão habitacional sempre se mostrou muito complexa diante do crescente contingente populacional e da pressão da sociedade em expandir o acesso à habitação e aos bens e serviços públicos.

$A$ ausência de uma estrutura de planejamento sempre dificultou 0 ordenamento territorial urbano e as ações e intervenções do governo. A ausência de uma base de dados e estudos urbanos gerava situações inesperadas e inusitadas que foram sempre suplantadas pelos discursos de melhoria e modernização para a cidade, mas que omitiam uma realidade social e econômica local desconsiderada pelas leis e normas urbanísticas, assim como pelos planos urbanísticos que nunca foram de fato implementados totalmente. A cidade passou a se expandir e a se consolidar segundo interesses dos investidores à parte dos interesses de seus habitantes, fato que ao longo dos anos acirrava conflitos e gerava experiências mal sucedidas na cidade. 


\subsection{Capítulo 2 - Um breve histórico de estruturação de uma região: dos obstáculos naturais às contradições na estruturação da região}

Assim, no contexto estratégico e geopolítico do governo federal de integração do território nacional, estudos elaborados pelo CNG (Conselho Nacional de Geografia) do IBGE (Instituto Brasileiro de Geografia e Estatística) nas décadas de 40 e 50 e publicados na RBG (Revista Brasileira de Geografia), atentavam para as condições de sítio e posição ${ }^{34}$ da cidade do Rio de Janeiro com a transferência da capital federal para Brasília. A cidade, então capital federal, estaria prestes a perder tal titularidade para Brasília. As análises das condições de sítio e posição da cidade do Rio de Janeiro foram determinantes para explicar as peculiaridades da cidade no ordenamento de seu território.

Os supostos problemas, oriundos da transferência da capital federal do Rio de Janeiro para Brasília, desencadeavam avaliações de diversos grupos. Os geógrafos atentavam para as condições de sítio de uma cidade. Características do relevo, do clima, do solo, da vegetação, entre outras seriam de grande importância, repercutindo nas condições de conforto dos seus habitantes, nas facilidades de comunicações internas, nas possibilidades de expansão da cidade. No entanto, a posição ou a situação da cidade em relação a outras áreas distintas, mesmo que muito afastadas em relação aos acidentes geográficos, adquiriria maior importância no ordenamento territorial. Deveriam

\footnotetext{
34 Segundo Davidovich e Geiger (1961: 272), ao fator posição, que juntamente com o fator sítio, representa o aspecto geográfico do estudo urbano, cabe o papel mais importante no desenvolvimento das cidades. P. George (1952) define posição “em relação ao conjunto regional, às bases de produção de matéria-prima e energia, às reservas de mão-de-obra, às zonas de contato ou vias de passagem naturais". E citando Lysia Bernardes que sintetiza que o fator posição também não se presta a uma classificação geral das cidades, pois se refere apenas a um único período da evolução das cidades, que às vezes, se confunde com a origem. Determinada posição pode ter sido essencial para o desenvolvimento de uma localidade numa certa época sem persistir sempre no mesmo papel. 0 exemplo já citado de Ouro Preto é ilustrativo (a partir do declínio do período do ciclo da mineração, a capital foi transferida para Belo Horizonte). Por outro lado, pode ocorrer que as cidades, embora permanecendo numa mesma posição, exerçam funções muito diferenciadas: é o caso das localidades do médio Paraíba, que ocupam posição de alinhamento de vale, mas possuem diversificação funcional. Apesar de se identificar como portos, Rio de Janeiro e Santos possuem conteúdo muito diverso. Não se pode encarar a posição de uma cidade como elemento estático: reveste-se de multiplicidade de aspectos, que depende do desenvolvimento da região, de maneira que, por si só, não é suficiente para uma classificação.
}

[Digite texto] 
ser considerados os cursos d'água importantes, as fronteiras políticas, as vias mestras de transportes e comunicações, a proximidade ou afastamento do mar; as suas relações como outras cidades e outras regiões do país, tendo em vista, as facilidades ou dificuldades de comunicações, de intercâmbio econômico, etc. Para os geógrafos, a posição seria muito mais importante que o sítio. Para o país, interessaria muito mais a posição em que se acha sua capital, do que o sítio (Guimarães: 1949).

No entanto, na percepção do ordenamento territorial, um inóspito sítio pode ser melhorado graças ao esforço humano, mas o homem nada poderia fazer quanto à posição. O sítio do Rio de Janeiro desde sua ocupação tem sido constantemente remodelado, com aterro de pântanos, arrasamento de morros, abertura de túneis, saneamento de certos bairros, mas, nada poderia alterar o fato de achar-se à beira-mar, de ter a pequena distância a grande barreira montanhosa que é a Serra do Mar, de possuir uma hinterland de determinadas características geográficas, etc.

Muito antes da sua fundação no dia $1^{\circ}$ de março de 1565 por Estácio de Sá, a transposição dos grandes obstáculos físicos, marcou o processo de expansão da cidade. Do local de sua fundação, entre o Morro Cara de Cão e o Pão de Açúcar, e após a transferência para o Morro do Castelo em 1567, por Mem de Sá, a cidade passou a se expandir em direção à planície. O sítio não se mostrava favorável às intervenções urbanísticas e nem à sua expansão. $O$ sítio original (Morro do Castelo) atendia muito mais às expectativas militares de defesa que the eram atribuídas na época para a construção de um núcleo fortificado. No entanto, devido aos obstáculos naturais do próprio sito original a ocupação e expansão em direção à planície ocorreu por numerosas intervenções urbanísticas. 
Figura 2 - Fundação da Cidade de São Sebastião do Rio de Janeiro - primeiro núcleo

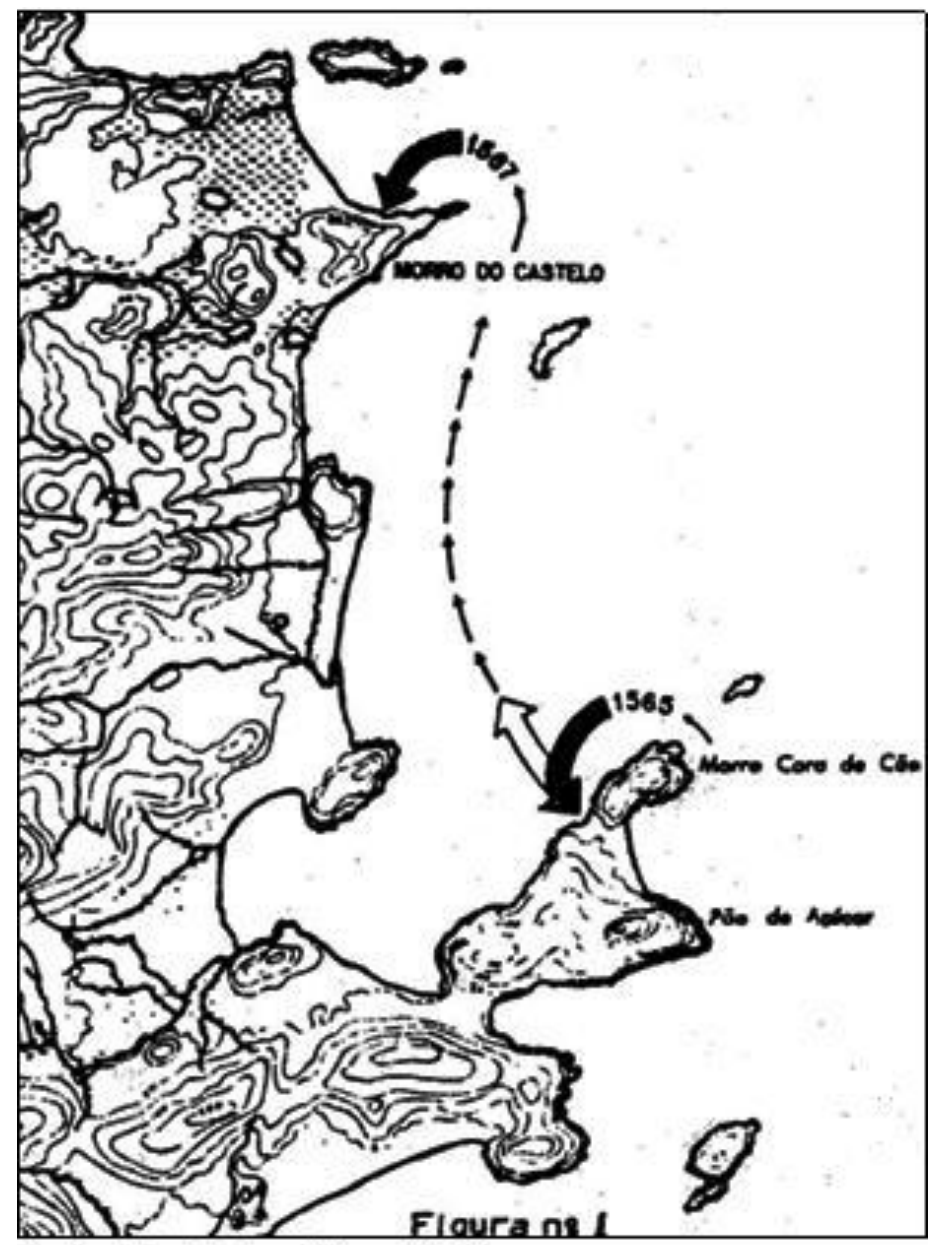

Fonte: Revista Arquitetura (1967)

As intensas intervenções antrópicas, tendo esses elementos físicos como obstáculos combinados com índice pluviométrico elevado, resultaram num terreno susceptível às grandes inundações e deslizamentos de encostas, embora o sistema hídrico de abastecimento se tornasse insuficiente diante do crescimento da população. A cidade do Rio de Janeiro constituiu uma exceção às cidades litorâneas, que geralmente se desenvolvem perto da foz de um grande rio, que lhes garantiria abastecimento de água doce. A ocupação e expansão da cidade foi resultado de um constante processo de combate às dificuldades naturais locais, mas com sérios efeitos indesejáveis ao meio ambiente.

A cidade em formação, confinada entre o brejo, o mar e a montanha foi alvo de intervenções pelo governo de modo a conquistar a planície, as colinas e os 
vales avançando sobre as regiões ribeirinhas alagadiças e montanhas a fim de ampliar o espaço em ocupação. Desmontes, aterros, terraplenagens, abertura de túneis entre outras técnicas foram fundamentais no processo de expansão do perímetro urbano. A cidade se expandiu incorporando diferentes sítios de modo diverso e em épocas diversas resultado das diferentes funções adquiridas e das intervenções no espaço urbano. A gestão do espaço sempre foi complicada no Rio de Janeiro, e seu custo bastante elevado.

No período colonial, as vantagens da posição da Guanabara, como a proximidade das Minas Gerais, contribuíram para a função de capital, mesmo depois de esgotadas as minas de ouro e consolidada a fronteira com os domínios espanhóis, mesmo assim; o Rio de Janeiro não perdeu sua posição de capital e desenvolveu-se como uma grande metrópole. A própria situação de capital, com seus órgãos de governo, pela presença da côrte e pelas condições de vida urbana e a função política e administrativa da cidade criaram uma concentração de vias de circulação que foram se expandindo para o interior.

Tendo por base estudos iniciais quanto às condições de sítio e posição da cidade do Rio de Janeiro, Bernardes (1962: p.4) sintetiza que embora as condições de sítio da cidade tivessem importância nos primórdios de sua ocupação quando assumiu a função de um núcleo fortificado, tais condições tinham se transformado em verdadeiros obstáculos para a sua expansão urbana.

Se ótimas eram as condições do sítio para a implantação de um núcleo fortificado, logo elas se tornaram um entrave ao desenvolvimento da cidade quando esta, ultrapassada a fase militar de fixação, ganhando a praia e a planície, precisou recorrer a obras de aterro e drenagem e palmo a palmo foi conquistando o atual espaço urbano.

Elementos físicos e naturais, como a Baía de Guanabara e a Serra do Mar, foram decisivos na posição da cidade e no desenvolvimento de suas respectivas funções assumidas ao longo de sua história; e, consequentemente, às ocupações de seu espaço. A função, como um entreposto comercial e porto exportador, assumida pela metrópole desencadeava a ocupação da Baixada da Guanabara em busca de terrenos agricultáveis para terem seus produtos 
exportados pela Baía de Guanabara. O próprio obstáculo natural da Serra do Mar levou atividades econômicas a se voltarem muito mais para as relações exteriorizadas do que em direção aos demais centros regionais próximos.

As dificuldades de domínio e ocupação pelo ambiente hostil eram superadas pelas características de sua posição geográfica que gerava fatores positivos e compensavam as condições de difícil ocupação local. Bernardes (1960: p.97) acrescenta que "essa expansão do Rio de Janeiro, apesar da inadequabilidade de muitos dos sítios conquistados, se iniciou desde logo, com o aparecimento de novas funções, pois, com efeito, diversos outros fatores ligados ao elemento posição, intervieram nesse sentido, garantindo, desse modo, a permanência do aglomerado crescente".

A região que se constituía, tinha na cidade do Rio de Janeiro um grande mercado consumidor, cujas necessidades crescentes atuaram diretamente nas formas de ocupação da região. As atividades econômicas dos centros regionais localizadas em torno da área central dependiam do mercado carioca. O papel monopolizador da metrópole carioca na expansão de sua área metropolitana foi decisivo para a construção de sua região metropolitana. A configuração territorial da região e sua infraestrutura física são resultados do acúmulo de funções assumidas pela metrópole (Bernardes, 1987)

A estruturação da cidade do Rio de Janeiro e de sua área de influência refletiu espacialmente os momentos marcantes de inserção do país no contexto da economia mundial. Da função portuária-exportadora de mercadorias oriundas dos engenhos da Baixada e das regiões próximas à função de centro econômico, político, administrativo e industrial do país, o acelerado crescimento da cidade esteve associado ao desenvolvimento de novas funções e da ampliação das antigas sob o predomínio dos interesses de uma elite que se urbanizava e do setor imobiliário especulativo que contribuíam para a segmentação do espaço urbano e a periferização da população de baixa renda, constituindo uma configuração urbana centro-periferia.

Vários fatores contribuíram para a configuração urbana centro-periferia, como a valoração da terra com base nos investimentos públicos do governo legitimada pelas leis e normas urbanísticas elitistas, da flexibilização dos códigos de obras, das dificuldades de regularizar a propriedade do solo urbano, das proximidades das amenidades urbanas, da acessibilidade aos meios de [Digite texto] 
transportes, assim como do planejamento urbano nas estruturas do governo quando supostamente buscava reduzir os impactos dos elementos externos (custos sociais) e garantir os investimentos do governo. Destaca-se a capacidade de barganha da elite urbana no processo político de manipular uma alocação dos investimentos públicos em infraestrutura e bens na área central que desencadeava uma valorização da terra e impunha a expulsão da população de baixa renda para as áreas periféricas de menor valor do ponto de vista dos investidores.

Este ciclo constante de valoração da terra, pelo retorno do pagamento dos benefícios pela população de alta renda que concentra os investimentos públicos nas áreas centrais, implicava diretamente na redução dos números de unidades industriais que passaram a buscar condições mais competitivas nas áreas periféricas ou fora da área de influência da cidade, em outros municípios e Estados. Assim, como a indústria de construção que, com o apoio do governo teoricamente direcionava seus investimentos para a construção de residências para população de baixa renda, passou para as construtoras que direcionaram seus investimentos às classes mais favorecidas, porém mais lucrativos, penalizando a política habitacional e agravando as condições de acesso à habitação principalmente da população de baixa renda.

O acúmulo das funções assumidas pela cidade do Rio de Janeiro ao longo dos anos foi dando as diretrizes da expansão e do ordenamento de seu próprio território, sem planejamento a partir de investimentos e de equipamentos mantidos pelos fluxos de mercadorias, pessoas e serviços que incorporavam a região de influência do Rio de Janeiro. Em outras palavras, a ocupação e expansão da área urbana estiveram muito mais atreladas, também ao papel político atribuído à cidade do Rio de Janeiro do que pelas determinações naturais de seu sítio, considerado um tanto quanto hostil (Bernardes, 1987).

A posição geográfica da cidade do Rio de Janeiro assumiu uma dimensão estratégica singular no processo de ocupação e consolidação do espaço, em contraposição, às características físicas de seu sítio, que impunham uma constante adaptação do homem ao meio às expectativas de ocupação e expansão da sociedade. No entanto, a importância da posição estaria muito mais ligada a um único período de evolução da cidade relacionado à sua origem. Não se justificaria a posição pelo fato da perda de sua importância com 
o passar dos anos e com as mudanças relativas às diferentes funções assumidas pela cidade em outros contextos históricos, políticos e econômicos.

Ao longo do processo de urbanização da cidade, os morros e montanhas cariocas obtiveram importâncias diferenciadas desde defesa do território, lugar de cultos religiosos, alternativa de moradia às áreas inundáveis e insalubres até serem destinados aos pobres, assim como os rios, as lagoas e os pântanos que permeavam a área urbana precisavam ser dominados, controlados e utilizados para alguma finalidade. Todos esses componentes do quadro natural da cidade sempre estiveram dissociados da área urbana, do planejamento urbano e das medidas de preservação. Por muito tempo os recursos naturais ficaram ausentes das normativas e regulamentações urbanísticas destinadas a controlar a expansão do espaço urbano.

Os escassos recursos hídricos, como rios e córregos da cidade, sempre foram tratados como meros canais destinados ao abastecimento de água ou ao escoamento de dejetos. Ao passo do processo de apropriação do espaço, os rios e córregos da cidade foram e ainda são percebidos e tratados como meros "canais" destinados ao abastecimento de água e ao escoamento de tudo aquilo que não presta ou não serve mais. Seu manejo e, consequentemente, sua inserção na paisagem foram fortemente fundamentados em paradigmas tecnicistas. A necessidade de captação de águas para abastecimento em pontos cada vez mais distantes do centro urbano, devido ao aumento da poluição e à diminuição do volume hídrico dos rios, fez com que a utilidade de preservá-los se tornasse abstrata para a população. Rios e córregos passaram a ser vistos e tratados apenas como "valas". Daí, resultou a dificuldade coletiva e, consequentemente, institucional, de reconhecer suas funções na paisagem carioca ( Schlee e Tângari, 2008), o que anulava toda e qualquer possiblidade de preservá-los, assim como de uma percepção coletiva que levasse aos necessários avanços institucionais.

A expansão urbana da região da Guanabara não ocupou toda a área do antigo Distrito Federal, porém, se realizou em diversas direções, acompanhando as grandes vias de comunicação para o interior e sem se prender aos limites político-administrativos. A progressão urbana extravasou das fronteiras do antigo Distrito Federal, fazendo expandir os pequenos centros fluminenses vizinhos da capital e criando as chamadas cidades-dormitórios 
como Niterói, São Gonçalo, Duque de Caxias, São João de Meriti, Nilópolis, Nova Iguaçu e Queimados e outras localidades menores.

Figura 3 - Plano de um Trecho do Rio de Janeiro e de Niterói

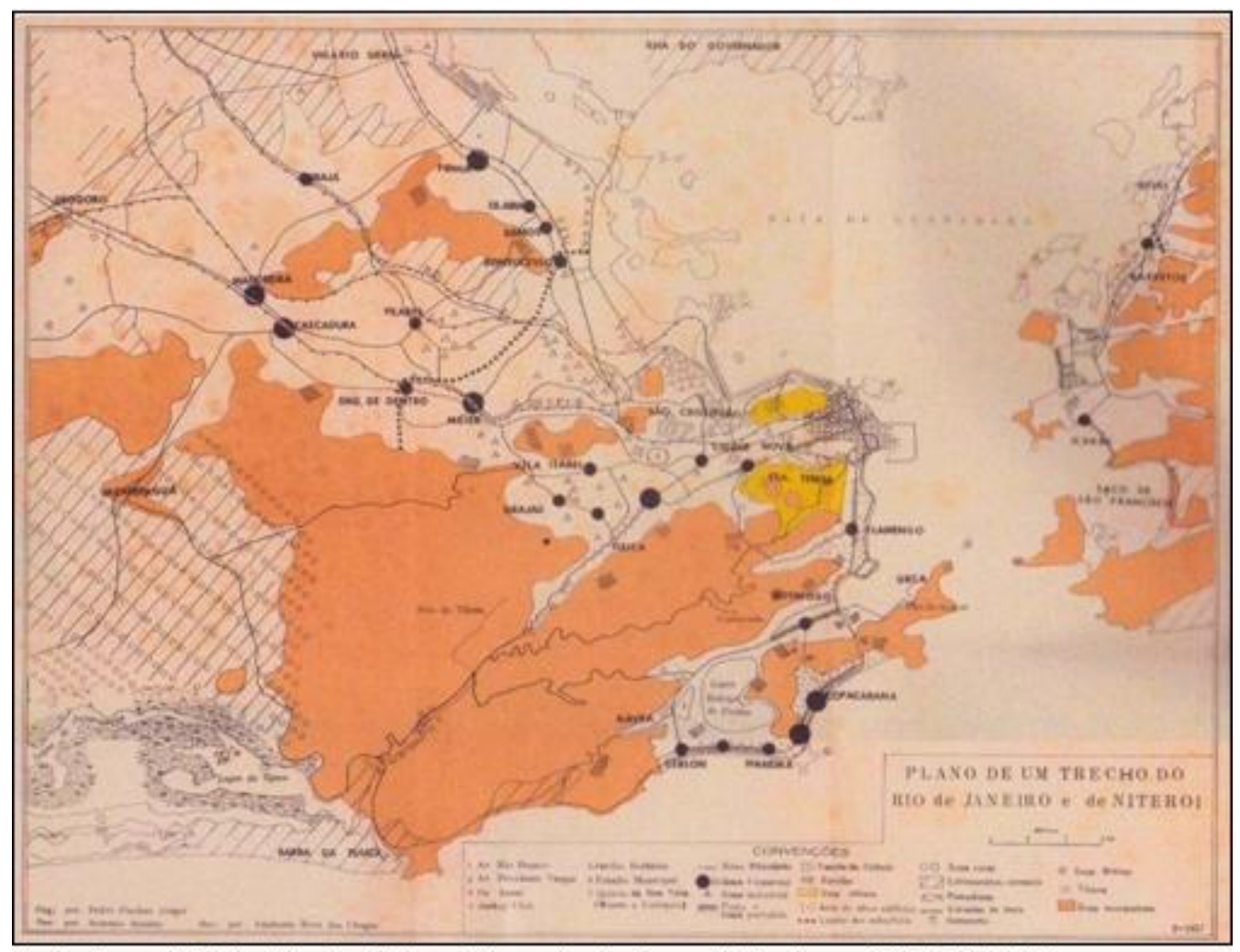

Fonte: Mapa de Pedro Pinchas Geiqer in Aspectos da Geocrafia Carioca- CNG- AGB, 1962.

A Baixada Fluminense, com destaque dos municípios de Nilópolis, Nova Iguaçu, Magé, São João de Meriti, Duque de Caxias, englobava as primeiras áreas (hinterlândia) que sofreram influência econômica e cultural da cidade do Rio de Janeiro, e foram incorporadas à área metropolitana do Rio de Janeiro. $O$ espaço da Região Metropolitana do Rio de Janeiro foi se consolidando ao passo que as relações sociais relacionadas à industrialização, ao comércio e serviços foram se estabelecendo, agregando outros municípios a sua área de influência ${ }^{35}$.

\footnotetext{
${ }^{35}$ A Lei Federal no 14, de 1973 não teria incluído o Rio de Janeiro entre as regiões metropolitanas de então, por estar o Grande Rio dividido entre dois Estados, o do Rio de Janeiro e o da Guanabara. Em 1974, a Lei no 20, que determinava a fusão entre os dois estados num único, o Estado do Rio de Janeiro, incorporaria todos os dispositivos da referida Lei no 14, bem como criou o Fundo Contábil para o Desenvolvimento da Região Metropolitana do Rio de Janeiro, destinado a financiar os programas e projetos prioritários para a Região.
}

[Digite texto] 
Figura 4 - Delimitação do Grande Rio

\section{O GRANDE RIO DE JANEIRO}

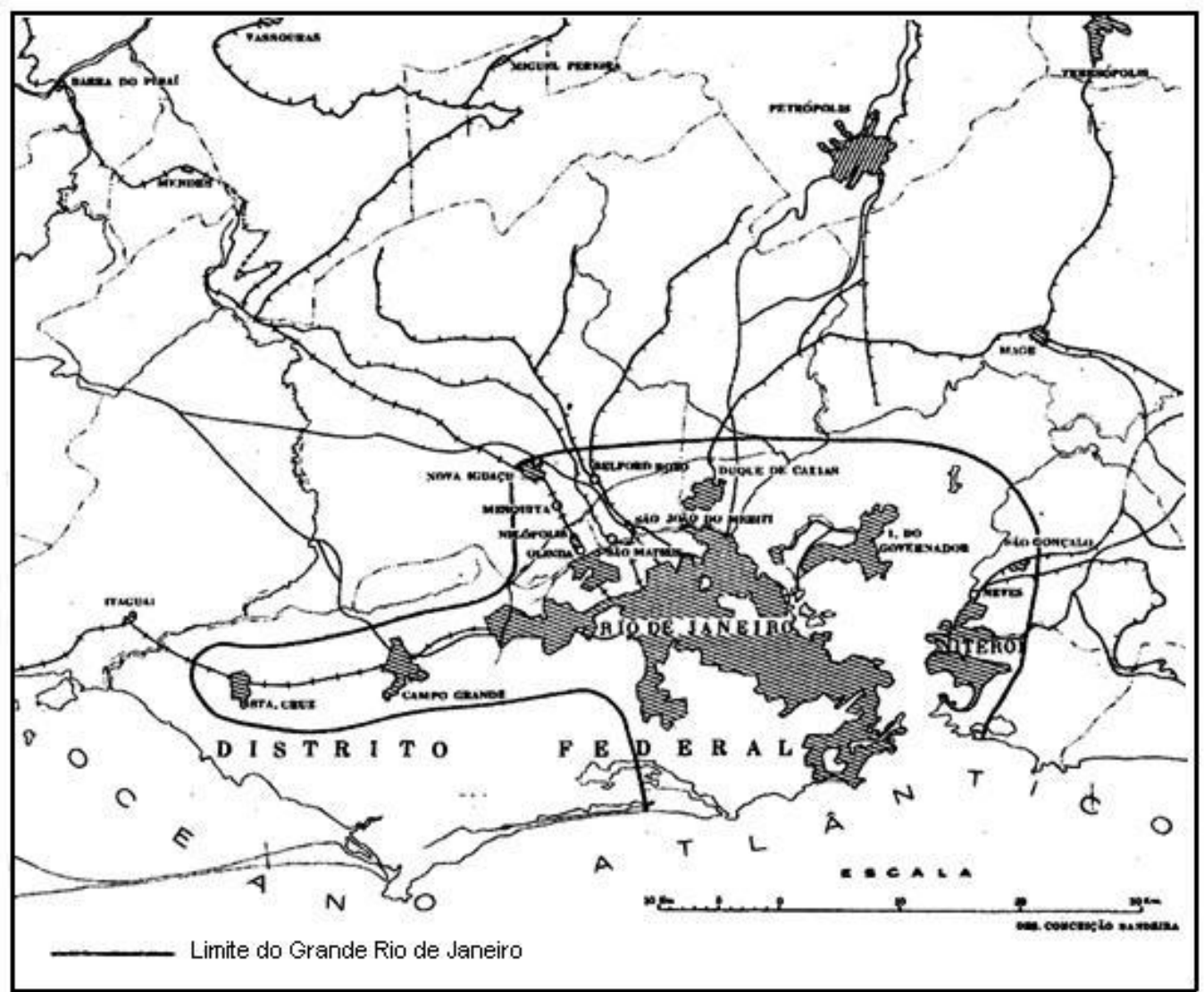

Fonte: Revista Brasileira de Geografia $\mathrm{n} 1$ de 1960.

Quando criada, a Região Metropolitana do Rio de Janeiro - RMRJ, contava com 14 municípios.

Desde então, sua composição alterou-se. Saíram municípios que faziam parte de sua primeira composição: Petrópolis, que passou a fazer parte da Região Serrana; Mangaratiba; Itaguaí, os dois primeiros passando a fazer parte da Região da Costa Verde; e Maricá, que passou para da Região da Baixadas Litorâneas.

O número de Municípios foi ainda alterado pela emancipação dos distritos, a partir dos anos 90. Foram emancipados: Belfort Roxo, Guapimirim, Queimados, Japeri, Tanguá, Seropédica e Mesquita.

Atualmente com a Lei Complementar No 105, de 2002, a RMRJ conta com 17 municípios: Rio de Janeiro, Belfort Roxo, Duque de Caxias, Guapimirim, Itaboraí, Japeri, Magé, Nilópolis, Niterói, Nova Iguaçu, Paracambi, Queimados, São Gonçalo, São João de Meriti, Seropédica, Mesquita e Tanguá. 
Mapa 1 - Região Metropolitana do Rio de Janeiro - 1974

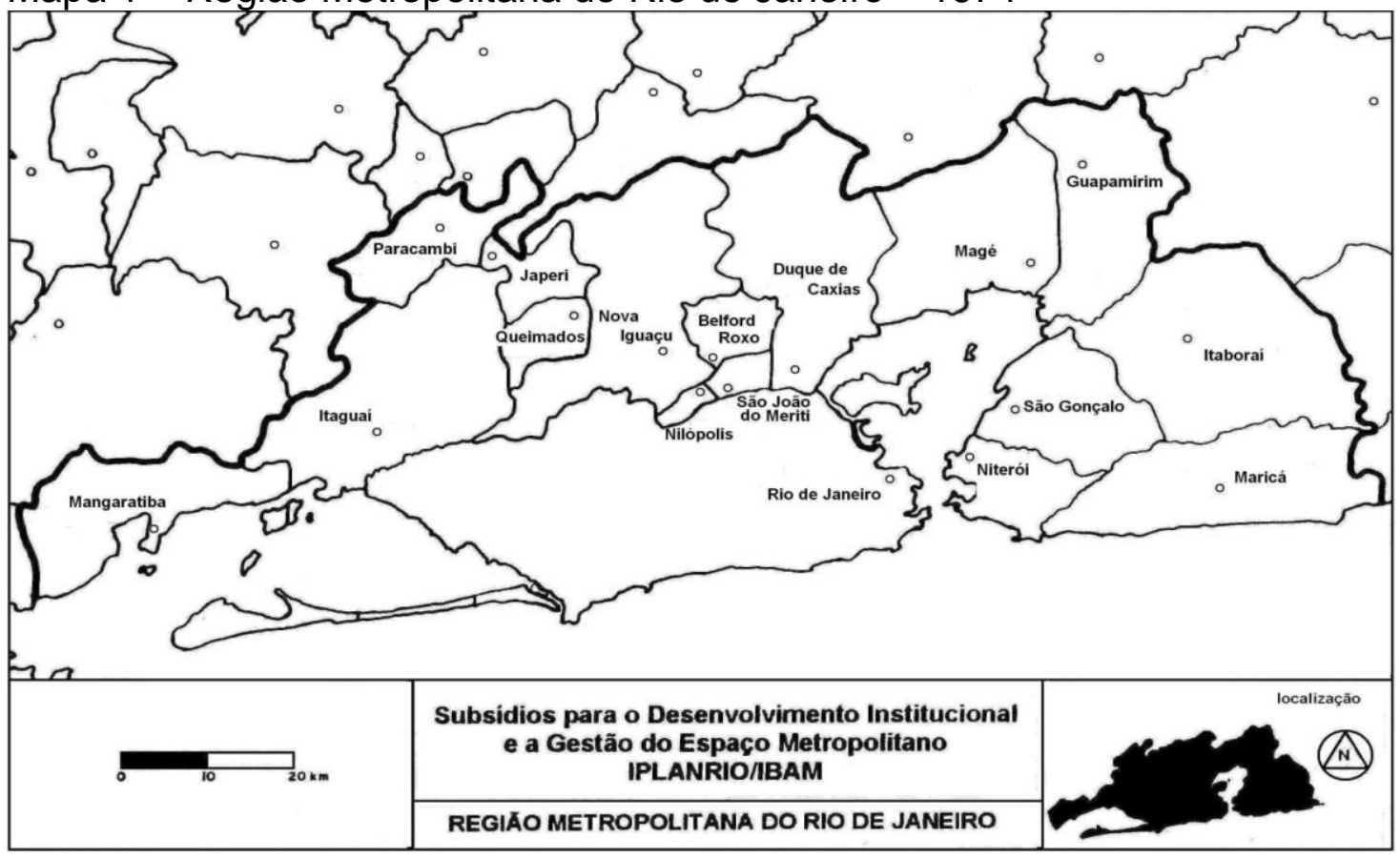

Fonte: IPLANRIO/IBAM (modificado)

Mapa 2 - Região Metropolitana do Rio de Janeiro - 2009

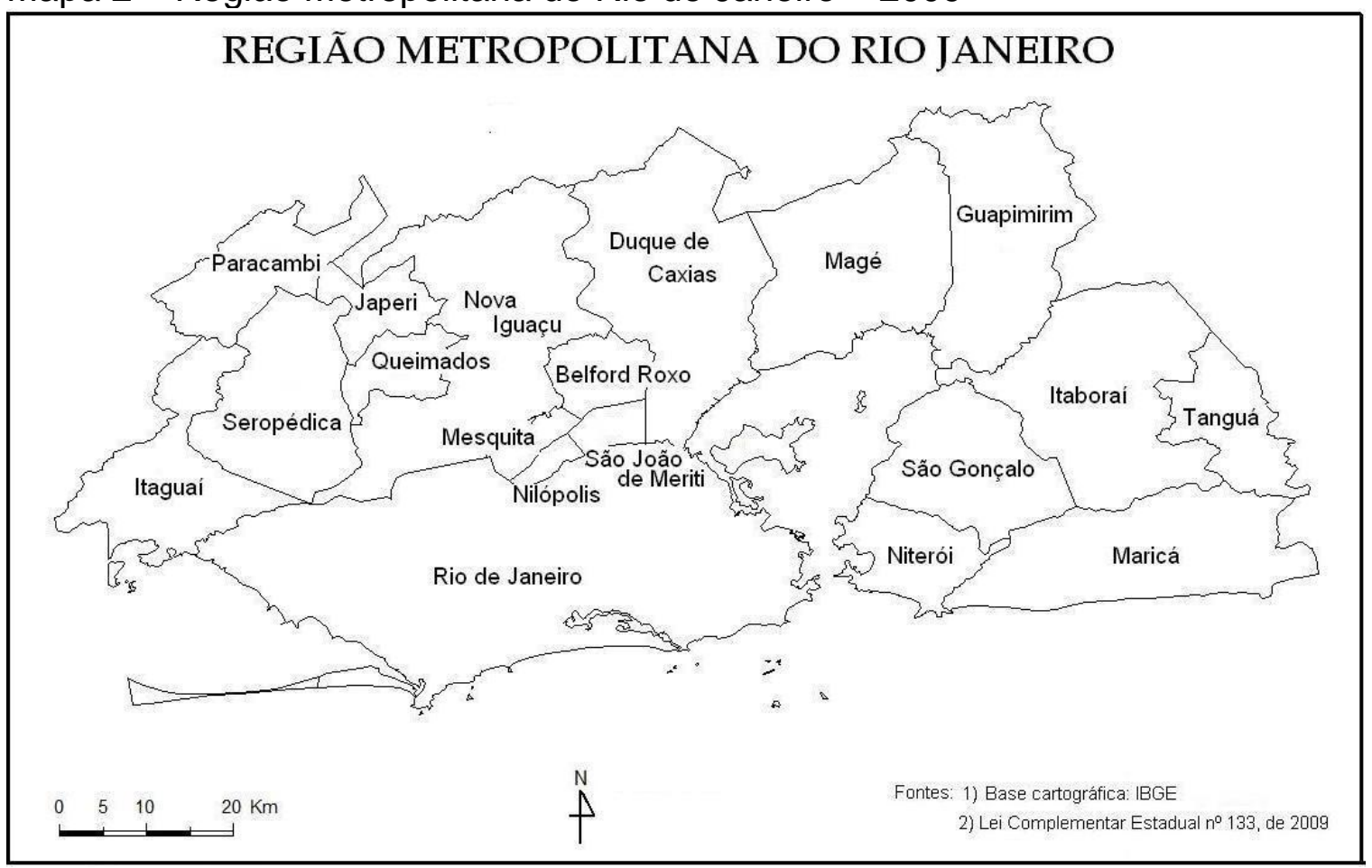


Concomitantemente à apropriação e consolidação do espaço com a forte presença intervencionista do governo e do setor privado, os terrenos sofriam uma valorização orientada pelo mercado imobiliário, excluindo a maioria da população de baixa renda do direito ao solo urbano e conduzindo-a a ocupar áreas longínquas dos locais de trabalho ou a ocupação dos terrenos desvalorizados desencadeando inúmeros problemas de locomoção, de habitação e de sobrecarga da infraestrutura urbana.

O crescimento "espontâneo" ${ }^{36}$ da cidade do Rio de Janeiro ocorreu sem um plano de governo que orientasse a expansão e teve as imposições do meio, como obstáculos ao longo do processo de domínio e apropriação do espaço, com reflexos na estrutura fundiária e na paisagem urbana. Nas áreas centrais como nos subúrbios e na Baixada, a ocupação do espaço ocorreu de forma descontínua, seja devido aos obstáculos físicos e as condições do sítio ${ }^{37}$, seja pelo interesse de particulares que ora retardavam o desmembramento de suas propriedades, ora o favoreciam através de loteamentos.

As dificuldades impostas pelo sítio à expansão da cidade e a ausência de planejamento resultaram nos graves problemas urbanos como ineficiência dos bens e serviços públicos, escassez de terrenos, favelização, impactos ambientais, dificuldades de acessibilidade, despreparo do espaço urbano às diferentes necessidades dos grupos sociais, sobrecarga nos equipamentos urbanos, fragilidade nas ocupações das encostas, com sérios impactos locais que se agravaram ao longo dos anos.

\footnotetext{
36 O crescimento espontâneo relaciona-se ao processo de crescimento demográfico associado às transformações do território cujo crescimento urbano passa a constituir uma dessas variantes dessa transformação. A ausência de mecanismos de regulação do território em rápida evolução origina o crescimento espontâneo em vez de um desenvolvimento urbano equilibrado. O processo de ocupação do solo é regido pelos interesses predominantes sem planejamento, fruto da ausência do Estado na região, sem preocupação em reservar espaços para futuras e necessárias adaptações do espaço às necessidades da sociedade como habitação, lazer, educação, saúde, saneamento, drenagem, circulação entre outros equipamentos e infraestrutura urbanos. A precária infraestrutura e a ocupação do solo não planejada expõem a população residente aos vários riscos sociais e ambientais.

37 Abreu (2010: 214, volume 2) expõe que em seus clássicos trabalhos sobre o Rio quinhentista, Lysia Bernardes afirmou corretamente que foram as vantagens da posição geográfica e não as características do sítio que determinaram o estabelecimento da cidade de São Sebastião no morro mais tarde conhecido como "do Castelo". Na realidade, se não existisse tais qualidades (o autor refere-se as qualidades já discutidas em outro capítulo de sua obra), dificilmente a cidade teria prosperado, tantos foram os óbices que os primeiros colonizadores tiveram de superar para afirmar a presença portuguesa num sítio que lhes era decididamente pouco favorável, senão hostil.
}

[Digite texto] 
A formação da metrópole do Rio de Janeiro relacionou-se ao ciclo industrial do país no século XX. O desenvolvimento das atividades industriais, que se fez acompanhar da expansão da vida urbana, acarretou a diminuição relativa da importância das atividades agrícolas em torno da área metropolitana. A cidade do Rio de Janeiro foi considerada um grande centro comercial antes do fim do século XIX e representava o mercado consumidor mais interessante para as pequenas indústrias de bens de consumo.

Após algumas obras de saneamento da Baixada da Guanabara, muitas indústrias se instalaram em busca de terrenos amplos e baratos, difíceis de serem encontrados nas áreas mais centrais, mão-de-obra de menor custo, impostos mais baixos e outras vantagens que os municípios ofereciam como mecanismo de atrair investimentos e população. Por sua vez, a política de atrair indústrias, investimentos e população, teve uma importância fundamental no processo de estruturação da metrópole e nos efeitos de sua economia. A drástica redução das atividades agrícolas e da pecuária pelo intenso loteamento no processo de expansão urbana conduziu a maior dependência da metrópole aos produtos primários.

Quanto ao processo de domínio e ocupação do espaço, a cidade do Rio de Janeiro adquiriu uma linearidade tão característica ocupando os eixos de vias que organizavam as ligações locais e que dependiam das intervenções do governo para transpor os obstáculos, como maciços rochosos ou elevados ou ruas em vales estreitos. Os bairros mais distantes que se formavam pela gradativa ocupação dos subúrbios e áreas periféricas não formaram um contínuo urbano, mas uma sucessão de espaços deficientemente articulados.

Tal linearidade condicionada pelo sistema de transporte no processo de domínio e ocupação do espaço dificultou as instalações de infraestrutura urbana e, de certa forma, permitiu abrigar diferentes estratos sociais sobre uma mesma localidade numa contiguidade entre os mais diversos grupos sociais. As características do conjunto dos elementos geográficos locais explicam a justaposição social que subsiste na cidade do Rio de Janeiro e influenciam nas políticas públicas.

A concentração dos investimentos na área central e a elevação do custo do solo urbano resultaram na expansão do processo de ocupação pela população de menor renda em direção ao subúrbio e a Baixada da Guanabara ou Baixada [Digite texto] 
Fluminense, composta por municípios que foram físico-territorialmente incorporados à sua área metropolitana. A ação e intervenção do governo foram fundamentais na expansão e ocupação da metrópole do Rio de Janeiro, embora num desordenado processo sem planejamento, expandindo a rede ferroviária e rodoviária ao subúrbio e implementando obras de saneamento e infraestrutura de modo a direcionar o vetor de expansão urbana, incorporando a Baixada à sua área metropolitana, embora a barreira institucional que separava o Distrito Federal do Estado do Rio de Janeiro tenha sido determinante no ordenamento territorial.

Outros elementos dificultavam qualquer presunção de se implantar uma estrutura de planejamento na cidade. Destaca-se a própria questão fundiária da cidade que sempre se apresentou complexa e susceptível às demandas judiciais quanto às titularidades e condições de apropriação do espaço. Desde a fundação da cidade do Rio de Janeiro, a complexidade quanto à questão de propriedade fundiária sempre esteve envolta de falta de clareza de seus documentos e irregularidades na titularidade, que impedem inclusive a arrecadação de tributos pelo governo assim como na implementação de políticas de ordenamento territorial. ${ }^{38}$

Segundo Abreu (2010:320 vol.1) as imprecisões dos títulos primordiais, a ausência ou demora de demarcações oficiais, a superposição de competências administrativas, a ocupação de fato pela posse, os contratos escusos e as deficiências de fiscalização tiveram papel preponderante nas demandas judiciais que cercariam o solo urbano. ${ }^{39}$ As questões relativas ao patrimônio

\footnotetext{
38 O engenheiro civil Gustavo Estienne (1904) relata em sua obra as incertezas quanto aos títulos de propriedade e demarcação das terras na fundação da Cidade de São Sebastião do Rio de Janeiro no processo de constituição do patrimônio territorial da cidade atribuídas à ausência de fontes documentais.

39 No período colonial, a Câmara Municipal, detentora de crescente poder dominial sobre os chãos da cidade, seja na antiga área alodial, onde crescia o número de terrenos que lhe eram foreiros, seja não "campo da cidade", que sempre fez parte de sua área patrimonial e através do qual a urbe se expandia, tornou-se o agente mais importante desse processo de crescimento urbano tanto por suas ações como por suas omissões. A capitania do Rio de Janeiro conheceu também, no início da colonização, outros conflitos de propriedade em grande parte, ocasionados por imprecisões contidas nas cartas de doação de terras, esses litígios geraram tensões contínuas no tecido social e alguns deles ultrapassaram em muito o período colonial. São poucos os documentos de natureza fundiária que subsistem desses primeiros tempos sendo notável que boa parte deles trate de conflitos que envolvem terras das "religiões". Essas corporações registravam em livros de tombo todos os títulos patrimoniais que possuíam e á a partir deles que temos notícias de quão frequentes eram as disputas fundiárias nas justiças coloniais. Ainda que as fontes que hoje existem sejam tendenciosas, pois dizem respeito, quase
}

[Digite texto] 
territorial da municipalidade emergiram com força na virada do século XIX para o século XX época em que a "guerra dos cortiços" e as reformas urbanas em curso, com todas as interferências que causavam sobre os direitos de propriedade estimularam debates acalorados sobre antigas questões territoriais.

$\mathrm{Na}$ análise preliminar das características de expansão da metrópole carioca, tomam-se como ponto de partida as limitações físicas e constitutivas da região metropolitana apresentadas desde a sua ocupação inicial até o processo de apropriação de suas terras. Os obstáculos físicos, os elevados custos para transformar ou adaptar o espaço pela crescente urbanização e as situações escusas quanto à titularidade da propriedade das terras desenhavam um quadro que se agravaria ao longo dos anos e que se tornaria refratário às políticas de ordenamento territorial.

$\mathrm{Na}$ sequência, avaliam-se as diversas condições políticas atribuídas à cidade, suas consequências e principais impactos sobre o ordenamento territorial urbano, evidenciando-se determinadas leis e normas fundamentais que contribuíram de modo incisivo nos aspectos urbanísticos de uma metrópole nacionalizada.

Por fim, deseja-se reconhecer que o período em que a cidade foi Distrito Federal (1763-1960), o nível de conurbação de sua área metropolitana associado aos mais graves problemas urbanos presentes da área metropolitana, resultaram das influências geopolíticas à época e do despreparo do governo local em lidar com o acúmulo e superposição de leis e normas urbanísticas responsáveis pelos obstáculos às políticas de ordenamento territorial urbano.

sempre, a questões de terras das "religiões", é certo que os pleitos judiciais que envolviam civis foram também numerosos, pois temos notícias deles aqui e ali. É possível igualmente que os altos custos impostos pelas longas demandas judiciais tenham levado à resolução informal de diversos litígios, pois disso dão prova diversas escrituras que oficializam a posteriori acordos e transações realizadas por papel particular (Abreu, 2010).

[Digite texto] 


\subsection{Capítulo 3 Uma avaliação da construção política de uma região: da ausência de planejamento ao espaço segmentado e segregado}

Nesta avaliação, consideram-se as políticas de ordenamento territorial urbanas na condição político-administrativa que a cidade do Rio de Janeiro adquiriu após a Proclamação da República em 1889 até 1960 como Distrito Federal. Tal condição político-administrativa foi de fundamental importância, sobretudo quanto às características da presença intervencionista do governo federal e o ideário de cidade nacionalizada, eminentemente cosmopolita e atípica, em comparação com o posicionamento político-regional das capitais dos grandes Estados brasileiros.

A avaliação que se apresenta tem por intenção justificar a reduzida articulação da cidade com sua respectiva região metropolitana com base na constituição política do Distrito Federal, interligando as características físicas do seu sítio às influências geopolíticas e políticas na segregação e segmentação de sua área metropolitana. Acrescenta-se a deficiente estrutura de planejamento e organizativa local, a sobreposição de leis e normas urbanísticas e os planos urbanístico, na composição do quadro complexo quanto às perspectivas do ordenamento territorial.

O longo período em que a cidade do Rio de Janeiro esteve na condição de Distrito Federal (1889 - 1960), o ordenamento territorial ficou marcado pelas relações políticas conflituosas entre as intervenções do governo federal e a disputa dos representantes políticos locais pela autonomia política da capital. Os conflitos políticos tinham por base a interferência direta do governo federal na cidade em contraposição, à luta das elites políticas por maior autonomia em suas decisões, de modo que os principais cargos políticos estratégicos foram preenchidos por representantes políticos cariocas a fim de enfrentar as constantes intervenções promovidas pelo executivo federal na capital.

Nesse período, o Distrito Federal recebeu um tratamento diferenciado pelo poder central, de modo a reafirmar a intervenção do governo federal no ordenamento de seu território, legitimada pelas Constituições Federais e leis que previam a criação de um conjunto institucional de difícil manejo com a presença de órgãos das esferas federal e municipal numa única unidade 
federativa, de modo provisório até a transferência definitiva da capital federal para o planalto central em 1960.

A constituição político-administrativa do Distrito Federal impôs um direcionamento convergente das decisões políticas locais sob grande influência do governo federal em detrimento de decisões políticas mais articuladas com sua área de influência em processo de consolidação. Tal quadro inflava discussões políticas locais sobre maior autonomia. Assim, a configuração político-institucional de complexa estrutura interna de poderes sobrepostos no Distrito Federal contribuía na significativa limitação das diferentes perspectivas políticas que conviviam num território extremamente polarizado, na tensão nacional e local com as interferências políticas locais nas decisões do governo federal e as interferências do governo federal nas decisões políticas locais, sem maiores avanços na perspectiva regional.

O texto constitucional estabelecia a criação de um Distrito Federal apartado de influências regionais. Estabeleceu-se que o Distrito Federal deveria ser governado por autoridades municipais sem qualquer menção ao desenho desse governo. No entanto, várias discussões foram travadas após a elaboração em 1892 da Lei Orgânica do Distrito Federal ${ }^{40}$ e após a aprovação da Constituição de 1891 de que o Rio de Janeiro não se tornaria um município qualquer e que deveria imediatamente possuir uma estrutura políticoinstitucional semelhante às das demais unidades federativas (Freire, 2002).

Nessa ocasião, políticos locais atentavam que o texto constitucional elevara a cidade à condição de Estado em preparação e propunham a criação de uma estrutura política baseada em um órgão legislativo eleito com amplos poderes legislativos e administrativos. Tal órgão elegeria um prefeito que ficaria encarregado de implementar as decisões do legislativo. De forma a não infringir a Constituição e nem os interesses cariocas, o Congresso Nacional definiu o

\footnotetext{
${ }^{40}$ A Lei Orgânica do Distrito Federal seguiu o modelo de Washington que não era bem visto pelos constituintes cariocas. O Distrito de Colúmbia era administrado por uma comissão de três pessoas, duas das quis nomeadas pelo presidente e pelo Senado por três anos, dentre os residentes no Distrito e a terceira escolhida pelo presidente no corpo de engenheiros do Exército por tempo indeterminado. Não havia funcionário eletivo e o Congresso legislava para o Distrito. Como Washington, a capital brasileira desprovida de se expressar politicamente, dever-se-ia dedicar à sua função precípua a de sediar a administração. Para os constituintes cariocas, o Distrito Federal era o lugar privilegiado da política e, como tal, deveria usufruir mais ampla liberdade para montar estruturas políticas locais. (Motta,2001)
}

[Digite texto] 
novo modelo político da capital e aprovou a criação da figura de um prefeito nomeado pelo Presidente da República com sanção senatorial.

Em vigor a Lei No 85 de 1892 relativa à organização municipal da capital federal, optou-se por um intervencionismo federal temperado que procurou não arriscar o princípio básico da representação popular. O novo regime permitiu a criação e o fortalecimento de grupos políticos locais que passaram a controlar a maioria dos cargos representativos municipais e federais. Foi um período de insolúveis problemas políticos e financeiros agravados pela intensa disputa pelo governo local entre a presença intervencionista do governo federal na capital e a autonomia política da capital. ${ }^{41}$

Os conflitos políticos tinham por base a interferência direta do governo federal na cidade, em contraposição, à luta das elites políticas por maior autonomia em suas decisões, de modo que os principais cargos políticos estratégicos foram preenchidos por representantes políticos cariocas a fim de enfrentar as constantes intervenções promovidas pelo executivo federal na capital. A condição, de Distrito Federal, levou a cidade ao total controle de suas decisões pelo governo federal e aprovação do Senado Federal; embora funções deliberativas fossem atribuídas à Câmara Municipal eletiva e os recursos tributários fossem os mesmos dos Estados e municípios, e as despesas de sua própria responsabilidade.

Segundo Freire (1997:14) "um aspecto que deve logo ser ressaltado foi o caráter limitado do raio de ação das elites cariocas, pois, como sede do governo federal, a cidade não possuía o direito de eleger seu prefeito que era nomeado diretamente pelo presidente da República. Além disso, os vetos do prefeito não eram examinados pelo Conselho Municipal e sim pelo Senado Federal. Isto fazia com que atores de diferentes níveis de poder estivessem

\footnotetext{
${ }^{41}$ Sob princípios nacionalistas e intervencionistas, o art. 15 da Constituição Federal de 1934 e no art. 30 da Constituição Federal de 1937 dispõem que o Distrito Federal será administrado por um prefeito, de nomeação do Presidente da República, com aprovação do Senado Federal, e demissível ad nutum cabendo as funções deliberativas a uma Câmara Municipal eletiva. As fontes de receita do Distrito Federal são as mesmas que competem aos Estados e municípios, cabendo-lhe todas as despesas de caráter local. No art. 70 da Constituição Federal de 1937 dispõe que o atual Distrito Federal enquanto sede do Governo da República será administrado pela União. Por sua vez, sob um ideário democrático, o art. 26 da Constituição Federal de 1946 dispõe que o Distrito Federal será administrado por Prefeito de nomeação do Presidente da República e terá Câmara eleita pelo povo, com funções legislativas.
}

[Digite texto] 
sempre presentes no campo político carioca e desviassem os assuntos de importância regional às questões nacionalizadas".

A estrutura local, ineficiente de arrecadação responsável pelos dados e controle da arrecadação destes tributos, favorecia o quadro de dependência dos repasses dos recursos do governo federal que por sua vez reforçavam seu poderio intervencionista no ordenamento do território do Distrito Federal. Atribuímos esse quadro às deficiências das estruturas organizativas locais e a baixa capacidade de pessoal e institucional do governo em arrecadar devidos tributos, facilitando as políticas clientelistas locais.

Desde o início do século $\mathrm{XX}$, as favelas tornaram-se presentes na estruturação espacial da cidade do Rio de Janeiro, como resultantes da ausência de uma política agrária capaz de absorver melhor a mão de obra que emigrou para as áreas urbanas e industrializadas modernas. No nosso estudo de caso, o crescimento demográfico ocorreu concomitante ao crescimento territorial e ao crescimento de seu mercado de trabalho. Uma das características marcantes foi à sobreposição de planos urbanísticos e leis urbanísticas a começar pela Reforma Passos ${ }^{42}$ que trazia o ideário da modernidade a partir de intervenções urbanísticas na área mais centralizada, contribuindo para a elevação do custo do solo urbano e a expulsão da população pobre para o subúrbio.

A proliferação das favelas na paisagem da cidade, no entanto, aconteceu nas primeiras décadas do século $X X$, após as reformas urbanas implementadas por Pereira Passos. O processo agravou-se devido à ausência de uma política de transporte para facilitar o acesso dos pobres aos locais de trabalho e devido à adoção de uma rígida legislação edilícia aplicada à cidade como um todo, o que acabou inviabilizando a ocupação dos subúrbios pelos extratos sociais mais pobres (Bahia e Tângari,2008).

Por sua vez, o valor imobiliário do solo urbano sempre foi bastante elevado e fora do alcance da maioria desse contingente foragido das áreas rurais que, na impossibilidade de habitar nos limites urbanos da cidade, pela ausência de infraestrutura, passaram a ocupar áreas desvalorizadas do ponto de vista

\footnotetext{
${ }^{42}$ A Reforma Passos consistiu em profundas mudanças na cidade do Rio de Janeiro, sobretudo, nos aspectos urbanísticos do então Distrito Federal promovidas pelo prefeito Francisco de Oliveira Passos que foi prefeito do Distrito Federal de 1903 a 1906.
}

[Digite texto] 
imobiliário, a invadir terrenos ou a se dirigir para áreas além dos limites urbanos sem qualquer controle do governo. Tal processo se acelerou ao passo da intensificação da industrialização dos principais centros urbanos e sempre esteve à margem das políticas de desenvolvimento urbano integrado do governo.

O crescimento desordenado desses espaços provocou um vasto debate e a necessidade de modificar a estrutura do governo para geri-los em sua complexidade. A questão de habitação não poderia mais ser concebida apenas a partir da gestão do habitat, mas, a partir do ordenamento do espaço urbano que se inseriria no espaço regional e nacional. A ausência de avanços institucionais relacionados às favelas e as leis e normas urbanísticas, assim como os planos urbanos, reforçavam e contribuíam para o aumento da favela na estruturação do espaço urbano.

Mesmo sendo reconhecida como realidade do processo de estruturação urbana da cidade, a favela tornou-se um grande desafio para a administração pública; até os anos 70 , era concebida como um mal a ser extirpado do contexto urbano pela tamanha desordem e ausência mínima de infraestrutura incapaz de suprir as necessidades de seus moradores. Os problemas urbanos se agravavam pelo simples fato das favelas não serem incluídas nos planos elaborados para a cidade. As favelas sempre foram tratadas como um problema localizado, alvo de intervenções localizadas, descontextualizadas das políticas de desenvolvimento urbano.

Algumas iniciativas chamavam atenção para a problemática das favelas no contexto urbano, com base na ameaça das influências comunistas no país num período de reconstrução da sociedade, buscando solucionar os problemas sociais para alcançar o desenvolvimento econômico. De herança do mal ao ideário de administrar e controlar as favelas no contexto urbano conhecê-la de fato tornou-se melhor caminho para manter o controle sobre seus habitantes e chamar a atenção do governo para a necessidade de uma urgente mudança na concepção do planejamento urbano. 
A influência científica e metodológica de Lebret, fundador do movimento Economia e Humanismo ${ }^{43}$, no planejamento urbano e regional no Brasil foram muito importantes desde os anos 50. No ano de 1960 foi publicado no jornal $O$ Estado de São Paulo um relatório sobre favelas do Rio de Janeiro: Aspectos Humanos da Favela Carioca elaborado pela equipe da SAGMACS e orientado por Lebret e que durou de 1957 a 1959. O referido relatório originou-se de um trabalho pioneiro baseado nos aspectos sociais das favelas que combinava análise de dados secundários, diários de campo dos pesquisadores envolvidos, entrevistas numa rigorosa conduta metodológica apoiada em estudos de casos e não por uma representação pré-formada da favela carioca.

A influência dos princípios da Escola de Chicago, que valorizava a pesquisa empírica, considerava a favela como um grande laboratório, apoiava-se na utilização simultânea de estudo de caso com os dados e estatísticas gerais e utilizava-se da representação gráfica como mapas, quadros, diagramas, fotografias. A ideia principal estaria voltada para a ação numa relação de pragmatismo e produção acadêmica apoiada na análise do micro para se entender o macro numa complementariedade entre disciplinas. Tal estudo foi de extrema importância para a compreensão da favela na época, não apenas como resultante de problemas econômicos e sociais de ordem nacional, mas, diretamente consequência da desorientação da expansão urbana, do mau uso da terra e da desorganização administrativa. (Anexo B)

A fim de atentar as autoridades na época sobre a necessária mudança na concepção do planejamento urbano, o estudo sobre as favelas cariocas desenvolvido pela Sagmacs - Sociedade de Análises Gráficas e

\footnotetext{
${ }^{43}$ A doutrina da Economia e Humanismo foi fundada por Lebret (1897-1966) na França em 1947 e a partir dos anos 50 propalou sua cientificidade e metodologia em outras partes do mundo como na America Latina, África e Ásia e postula um planejamento flexível, descentralizado a partir de unidades territoriais de base e de grupos organizados de representatividade da sociedade que são os mais qualificados para expressar as necessidades concretas e as potencialidades de uma população a fim de participar o máximo de cidadãos à elaboração e à realização de um projeto comum em vista da elevação das condições humanas a partir do ordenamento territorial. Destaca-se em 1956 quando a prefeitura de São Paulo contratou a SAGMACS para realizar a primeira análise da aglomeração paulista e a elaboração do projeto de planejamento do desenvolvimento urbano de São Paulo. Até hoje a pesquisa da SAGMACS foi um dos estudos mais profundos e complexos realizados sobre a metrópole paulista e posteriormente aos estados do Paraná, Santa Catarina e Rio Grande do Sul; ambas contatadas pela CIBPU- Comissão Interestadual da Bacia Paraná-Uruguai; assim como a experiência sobre o desenvolvimento e a implantação de indústrias em Pernambuco. A SAGMACS era formada por uma equipe multidisciplinar interessada em aplicar ao urbanismo brasileiro as ideias do movimento Economia e Humanismo.
}

[Digite texto] 
Mecanográficas Aplicadas aos Complexos Sociais ${ }^{44}$ de 1957 a 1959, sob a responsabilidade científica de Lebret e direção técnica do Prof.José Arthur Rios e coordenação o Sr. Carlos Alberto de Medina e cooperação do arquiteto Helio Modesto, concluiu que às favelas, consideradas agrupamentos desordenado das precárias habitações nunca foram aplicadas as medidas que regulavam 0 desenvolvimento urbano, a não ser por determinações proibitivas.

Quando as favelas passaram a constituir ameaça social, higiênica e estética foram colocadas sob jurisdição de órgãos especializados autônomos, sem ligação com o órgão orientador do crescimento urbano, no caso o Departamento de Urbanismo da Prefeitura do Distrito Federal. Este, por outro lado, encarava de modo peculiar o desenvolvimento da cidade. Regulava apenas o seu desenvolvimento físico, o parcelamento da terra, o volume das edificações, a abertura de logradouros públicos, etc. $O$ controle das funções urbanas, sua localização dimensionamento e inter-relação não estão compreendidos na ação administrativa. Valendo-se dos estudos desenvolvidos o relatório Sagmacs (1957-1959:4) aponta que

Essa expulsão do proletariado urbano carioca para a periferia teria tomado a configuração que o mesmo movimento assume em outras cidades, na mesma fase de desenvolvimento, não fossem dois fatores que Ihe imprimiram feição peculiar: um deles foi a inexistência de rede de transportes, cuja expansão pudesse acompanhar no mesmo ritmo, o crescimento do Rio de Janeiro. O outro foi a existência de morros, no coração da cidade, que, nesse estágio da técnica, só poderiam ser povoados com grandes inversões de capital e equipamento e que, segundo tudo indica, embora não ocupados, já estariam apropriados.

O relatório dos estudos desenvolvido pela SAGMACS apontava que os órgãos ${ }^{45}$ encarregados dos problemas das favelas não coordenavam suas

\footnotetext{
${ }^{44}$ Verdadeiro escritório de estudos e planejamento, a SAGMACS introduziu uma prática interdisciplinar e desenvolveu, pela primeira vez no Brasil, estudos de organização urbana e planificação territorial produzindo o estudo inaugural Estrutura urbana da aglomeração paulistana e a partir do financiamento do estudo sobre as favelas cariocas pelo jornal $O$ Estado de São Paulo foi publicado nos anos 50 Aspectos Humanos da Favela Carioca.

45 Tomamos como exemplo o SERFHA- Serviço Especial de Recuperação para as Habitações AntiHigiênicas criado em 1956 pelo município, composto pelo presidente que era o próprio prefeito e

[Digite texto]
} 
proposições com as diretrizes do crescimento urbano e nem essas incluíam medidas visando à solução dos problemas sociais e de infraestrutura (Anexos C). O problema das favelas, independente das causas ligadas a conjuntura nacional, atingiu a gravidade atual em virtude de não ter sido considerado como parte integrante da realidade urbana. Os órgãos responsáveis pela questão urbanística da cidade não concebiam o território do Distrito Federal como um todo e dessa forma suas intervenções eram pontuais, descontextualizadas da necessidade de um planejamento mais amplo no desenvolvimento urbano, que possibilitasse maior integração entre as esferas do governo.

No âmbito nacional, constatava-se o crescimento da participação das camadas médias e populares da sociedade brasileira nas decisões políticas. Em uma sociedade essencialmente agrária, a ordem jurídica vigente pautava a reflexão urbana na noção da propriedade privada individual e irrestrita que expressava assim, a ideologia do legalismo liberal. Esta ordem jurídica se mostrou completamente ineficaz durante o processo acelerado de urbanização que o país vinha sofrendo desde o início da década de 1920. Neste contexto, a Revolução de 1930 representou uma profunda modificação das estruturas políticas e repercutiu profundamente na reflexão sobre o direito urbanístico. Tanto a Constituição de 1934, como a do Estado Novo de 1937, sustentaram o princípio da função social da propriedade, o que gerou vários conflitos jurídicos, pois tal princípio ia de encontro ao princípio liberal da propriedade privada evocado pelo Código Civil de $1916^{46}$.

No âmbito da política local, a prefeitura ${ }^{47}$ revogou o plano de urbanismo elaborado por Alfred Agache $^{48}$, que previa inúmeras desapropriações e

dirigido por um Conselho Técnico composto de seis membros e um coordenador. Esses seis membros representavam as principais entidades que enfrentavam o problema das favelas como Departamento de Higiene, Fundação da Casa Popular, Polícia de Vigilância, Departamento Sanitário, Fundação Leão XIII, etc. O SERFHA intermediava ações para equilibrar os problemas da favela prestando serviços à população favelada e contribuindo para o levantamento de dados sobre a população favelada no processo de conhecimento dessas aglomerações que cresciam na cidade.

46 - Segundo o código só adquire-se propriedade imóvel pela transcrição do título de transferência no registro do imóvel, pela acessão, pelo usucapião e pelo direito hereditário.

${ }^{47}$ O prefeito do Distrito Federal Pedro Ernesto (1935-1937) assumiu uma nova política entre o poder público e a população favelada. A imagem extremamente popular do prefeito e as políticas públicas elaboradas na época evidenciavam uma aceitação da favela como parte integrante da cidade e compactuava com as políticas populistas do governo de Getúlio Vargas

[Digite texto] 
remoções das favelas e modificou a relação entre os poderes públicos e a população menos favorecida assumindo o caráter populista. Foi implantado um modelo mais político, centrado nas questões sociais. Esta politização da esfera local visava elevar as massas, de maneira que estas, sob o controle do Estado, adquirissem a plena cidadania. As favelas passavam pelo reconhecimento que poderia ser uma resposta concreta ao problema de moradia. Apesar da ausência de mudanças significativas na legislação urbana e de instrumentos jurídicos eficazes contra as remoções, o número de favelas foi crescendo revelando ser necessária urgente mudança no planejamento urbano e não apenas urbano, mas, regional.

\footnotetext{
${ }^{48}$ Plano de Remodelação Urbana laborado ao final da década de 20 por solicitação do prefeito da cidade Antônio Prado Junior. O referido plano foi um marco do urbanismo na época e tinha o objetivo de resolver os problemas funcionais da cidade e dar-lhe uma feição de capital. O Plano Agache inseria-se no contexto de remodelação, extensão e embelezamento da cidade.
}

[Digite texto] 
Figura 5 - O Plano Agache

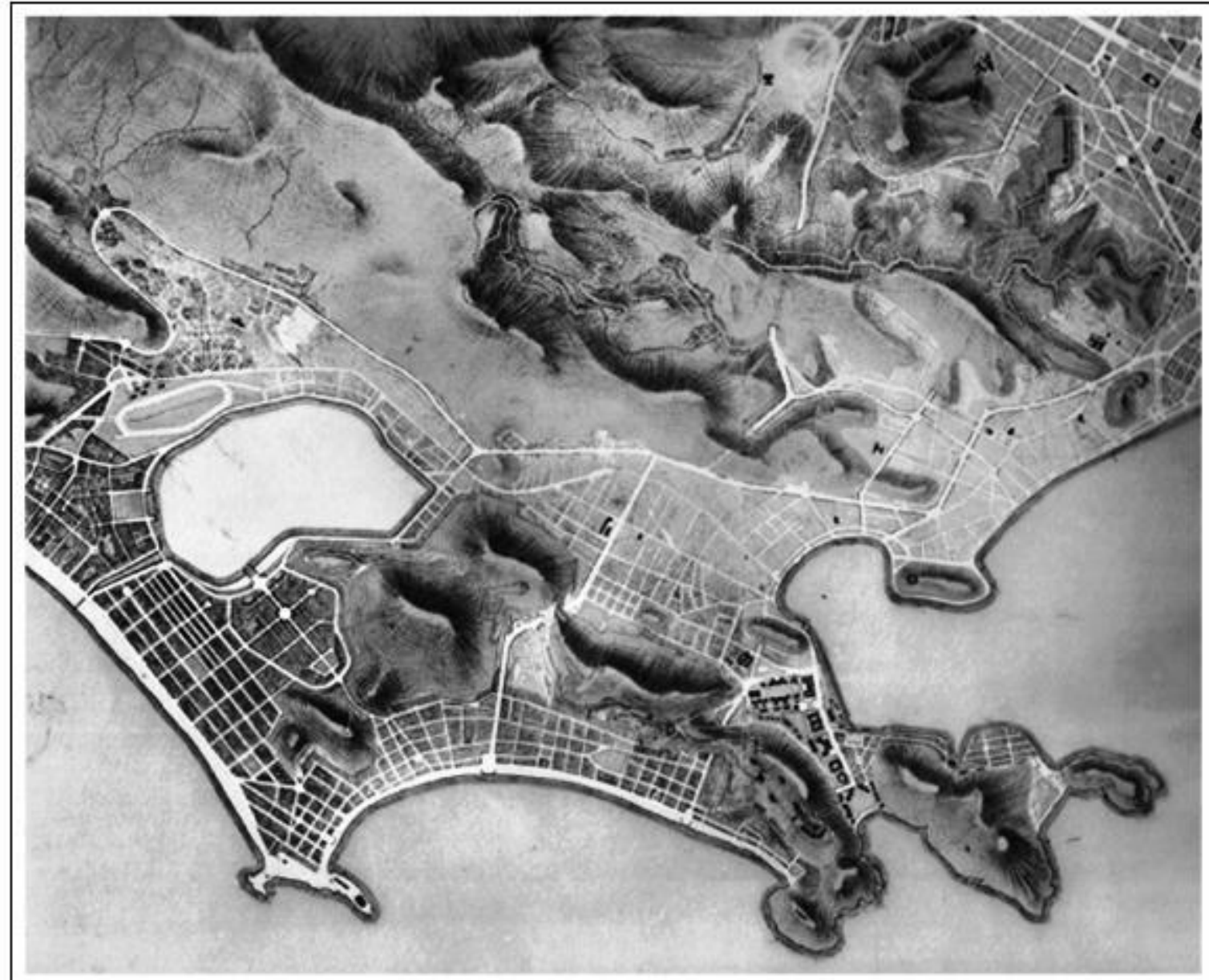

Figura 4: Plano Agache com a inclusăo do projeto de Z. B Amaral. Fonte: Agache, A. D. Cidade do Rio de Janeiro, remodelaçăo, extensăo e embelezamento: Ed. Foyer Brésilien, 1930.

Fonte: http:/humw. revistasusp. sibi.usp.briscielo

Os instrumentos tradicionais, disciplinadores do uso do solo, superpuseram-se em rígidos códigos de obras, especificações sobre 0 zoneamento, códigos de posturas municipais e planos diretores, baseados em definições de usos e parâmetros edilícios que contribuíam para a elevação dos custos e colocou os bens imobiliários fora do alcance da maioria da população de baixa renda pela ausência de um instrumento que os integrasse e criasse uma unidade de planejamento da cidade, considerando as relações sociais, a apropriação desigual da terra urbana, o déficit habitacional e de bens e serviços. $O$ arcabouço normativo estabelecido a priori para a cidade estivera relacionado ao ordenamento edilício do núcleo urbano e, posteriormente, aos aspectos urbanísticos, excluindo por completo a área periférica que se expandiu e se consolidou sem planejamento. 
A legislação municipal, vigente ou o Código de Obras- Decreto 6000 de 1937 consolidou a favela no contexto urbano da cidade; com relação à habitação popular, limitou-se a fixar normas construtivas mínimas sem um aprofundamento político de aquisição dos imóveis urbanos pela população menos favorecida. A lei proibia a formação de novas favelas e o acréscimo das existentes. A política de provisão de habitação na cidade foi praticamente entregue à iniciativa privada que não via condições lucrativas, para a construção de habitações populares sem subvenção do governo que, por sua vez, adotava medidas supostamente favoráveis ao trabalhador e afastava 0 capital privado dos investimentos em habitações populares. A edificação de conjuntos em áreas com sérios diferenciais de serviços públicos só vieram agravar tal situação. As medidas de ampliação da área urbana sem serviços públicos essenciais impulsionaram 0 retorno às áreas centrais. Tal concentração populacional contribuía para a valorização dos terrenos e, consequentemente; a saturação dos serviços públicos.

O Código de Obras de 1937 inaugurou, assim, uma nova face jurídicopolítica em relação às favelas, o que revelou certo retrocesso em relação à política implementada na época pela administração Pedro Ernesto ${ }^{49}$. As favelas adquiririam um estatuto jurídico sui generis (CONN, 1968:51 apud Gonçalves, 2007). Esta espécie de vácuo jurídico legitimaria a falta de investimentos públicos nestes espaços de forma que na formação e na expansão inicial das favelas levaria a concluir que o direito teve um papel central na consolidação da favela, como elemento ao mesmo tempo marginal e estrutural do espaço urbano carioca (Gonçalves, 2007).

O Código de Obras de 1937 foi o primeiro documento oficial do governo na época a oferecer uma definição de favela, bem como foi o primeiro a esboçar um tratamento sistemático para as favelas, trazendo, assim, os princípios básicos de uma política estatal voltada para elas. Por fim, constitui-se aí a situação em que as favelas são colocadas numa situação irregular, quer do ponto de vista fundiário - pela ausência de título formal, legitimador da posse quer do ponto de vista urbanístico - pela violação das normas edilícias e de

\footnotetext{
${ }^{49}$ O Prefeito do Distrito Federal (1935-1936) inaugurou um modelo mais político, centrado nas questões sociais. As ações do governo valorizavam e inseriam as favelas no contexto urbano, embora reafirmassem características populistas do prefeito.
}

[Digite texto] 
parcelamento da terra. Pode-se afirmar, em síntese, que, com o Código de 1937, as favelas passam da invisibilidade à ilegalidade.

$\mathrm{Na}$ condição de Distrito Federal, a cidade do Rio de Janeiro refletiu as interferências culturais externas, no contexto de uma lógica hegemônica elitista expressa nas mudanças dos hábitos e costumes da sociedade e nas intervenções no seu espaço, adaptando-o ao processo de industrialização e modernização vigentes. Após um longo período de intensas transformações urbanas sob o ideário do disciplinamento e do higienismo urbanos, em $1937^{50}$, o Código de Obras e Legislação Complementar do Distrito Federal ou Decreto 6000 que tratava a questão urbana sob aspecto técnico do zoneamento, loteamento, construções, licenciamento, aspectos paisagístico e urbanístico da época, caracterizando o cunho normativo elitista da questão urbana e perpetuando os mecanismos de segregação social e espacial no processo de expansão urbana, reforçando o caráter descontextualizado da favela no processo de expansão urbana, a ponto de proibir sua expansão, sem grandes resultados.

A chancela militar e o caráter provisório atribuído a essas habitações contribuíram para a inação da Saúde Pública, tão empenhada em coordenar as habitações insalubres. Ressalta-se ainda que esse aparente paradoxo escondia a aceitação, por parte do poder público, da permanência das favelas no cenário urbano para garantir a estabilidade social necessária ao processo de acumulação, uma vez que seus habitantes representavam uma reserva de mão-de-obra necessária para a indústria, a construção civil e para a prestação de serviços domésticos (Abreu, 2006).

Essa postura explica a ausência das favelas nos recenseamentos e nos mapas da cidade até 1930, apesar de já estarem presentes no tecido urbano da cidade real. Até então, as favelas eram consideradas uma solução habitacional provisória e ilegal, desprezadas urbanisticamente, razão pela qual o poder público não via sentido em mensurá-las e/ou delimitá-las fisicamente.

\footnotetext{
50 A Prefeitura do Distrito Federal tomava medidas legitimadas pelo Decreto 5934 substituindo o financiamento do Plano de Transformação e Extensão da Cidade e a Comissão do Plano da Cidade (Decreto 5092) considerado muito avançado para a época. A Comissão do Plano da Cidade foi transformada em 1945 em Departamento de Urbanismo subordinado à Secretaria de Viação e Obras. Esta alteração em nada modificou o padrão dos trabalhos realizados baseado no traçado de ruas, gabaritos, projetos de aterros e parques.
}

[Digite texto] 
Foi a partir da década de 1930 que o poder público se deu conta oficialmente de que uma nova geopolítica havia se instaurado na cidade. Tendo ainda como mote principal a questão da salubridade, as administrações públicas iniciaram, a partir de 1940, uma série de levantamentos nas favelas com o objetivo de cadastrar seus habitantes e transferi-los das áreas valorizadas da cidade para os assentamentos a serem construídos (Abreu, 2006).

O exame da legislação urbanística e edilícia produzida a partir do final do século XIX até os dias atuais permite perceber que a evolução do pensamento urbanístico no Rio de Janeiro apresenta características peculiares. A lógica urbanística, de início, norteada por questões relacionadas à salubridade e fortemente subordinada ao pensamento higienista, passou a incorporar gradativamente preocupações relativas à aparência do conjunto urbano; ao ordenamento das atividades e usos; à delimitação entre o domínio público e privado; e à tentativa de solução do problema habitacional da classe proletária através do estabelecimento de padrões mínimos de habitabilidade (Bahia e Tângari, 2008).

A partir da década de 1930, a introdução de elementos reguladores de abrangência urbanística e de uma visão de urbanismo pautada pelo ideário econômico, rompeu com o enfoque preexistente, centrado na edificação e atrelado à visão higienista que se iniciou no século XIX com os Códigos de Posturas. A prática do urbanismo brasileiro, calcada na contínua edição de leis e decretos, consolidou-se nessa época. Nos instrumentos legais estabelecidos, os efeitos do zoneamento suplantaram os planos urbanísticos, em termos de alcance. (Feldman, 2001).

Ao longo do processo de expansão da cidade, o crescimento urbano e a configuração da paisagem formal no Rio de Janeiro foram pautados por diversos instrumentos legais: códigos de posturas, decretos e leis imperiais, leis orgânicas e complementares, planos diretores, leis e decretos federais, estaduais e municipais específicas (setoriais), códigos de obras, regulamentos de zoneamento, parcelamento e de edificações, projetos de estruturação urbana e áreas de preservação do patrimônio natural e cultural. Tais instrumentos, editados para controlar e ordenar o uso e a ocupação, as construções e o parcelamento da terra urbana privada, superpuseram-se à falta 
de um instrumento que os integrasse, deixando transparecer a ausência de unidade no planejamento da cidade (Resende,1996).

Nota-se a evidente falta de relação entre as normas estabelecidas ao longo do tempo e os planos urbanísticos que foram elaborados para a cidade em momentos distintos; Agache (1930), Doxíadis (1965) e PUB-RIO (1977), Plano Diretor Decenal (1992) e Plano Estratégico (1996). Atribui-se essa falta de conexão ao descompasso entre os objetivos dos planos e os interesses imobiliários que sempre incidiram fortemente sobre a atuação pública (Resende,1996 e Araújo, 2005).

A ausência de planejamento do governo capaz de ordenar a expansão urbana e o modo como os interesses especulativos do setor imobiliário lideraram tal processo, agravado pelo ambiente de elevada inflação, elevado custo de vida e das construções que afastavam as pessoas de baixa renda do acesso à casa própria, assumindo a cidade uma configuração peculiar. Silva (1976: p.115) sintetiza como a política habitacional era conduzida antes da mudança do regime político no país:

Antes de 1964, a ideia de construir habitações para a classe pobre apresentava um teor muito paternalístico. Caracterizava-se pelo fato de que os empréstimos não levavam em conta a inflação, e o capital aplicado decrescia em valor real, e, consequentemente, as amortizações eram cada vez menores em proporção a quantia emprestada. Verifica-se que os empréstimos para habitação eram, na realidade, doações que se distinguiam como privilégio político e social, de fácil acesso apenas a um reduzido número de pessoas. Os programas habitacionais careciam de um esquema global para sua efetivação. Eram desenvolvidos principalmente por entidades bancárias de poupança, como as "Caixas Econômicas", ou por Fundos de Previdência de vários institutos, destinados a atender grandes contingentes ocupacionais da população.

A constituição do patrimônio territorial da cidade do Rio de Janeiro e de sua área de influência foi determinada pelo crescimento desordenado, pela valorização do solo urbano, pelos interesses dominantes e pela negligência do poder público em estabelecer medidas e demarcações das terras e critérios de acesso ao domínio de suas terras. Os acidentes geográficos serviram de 
parâmetro no parcelamento do território e terrenos de difícil acessibilidade foram excluídos de todo o processo de parcelamento e legalização de suas terras e posteriormente, no contexto de uma lógica elitista de intervenção no espaço, destinados à ocupação pela população de baixa renda.

O período em que a cidade do Rio de Janeiro assumiu a condição de Distrito Federal, sede do governo federal, foi determinante na estruturação do espaço urbano segmentado, segregado e desarticulado de sua região de influência legitimado pelo conjunto de planos, leis e normas urbanísticas. A ausência de uma unidade política urbana, a forte interferência do governo central nas políticas locais e o agravamento dos problemas urbanos, como a favelização, apontavam para novas concepções e percepções do ordenamento territorial urbano. No contexto das influências das políticas de ordenamento territorial direcionadas ao território nacional, apoiadas no discurso de atenuar as disparidades regionais, o Distrito Federal foi transferido para o planalto central e se instaurou o Estado da Guanabara. 


\subsection{Capítulo 4 - Uma região atípica ao ideário do planejamento integrado: os ideais nacionais e locais em jogo na metrópole}

Com o ordenamento territorial urbano na condição político-administrativa que a cidade do Rio de Janeiro adquiriu de 1960 a 1975 com a transferência da capital federal para Brasília e a instauração do Estado da Guanabara e após uma manobra estratégica do governo federal, a fusão dos dois Estados, a cidade tornou-se município e capital do Estado do Rio de Janeiro, numa realidade reconhecidamente metropolitana. A avaliação que se segue consiste em reconhecer que esse período ficou marcado pela sobreposição de governos atuando sobre o mesmo território, sobreposição de órgãos do governo e de planos, leis e normas numa situação difusa quanto às políticas de ordenamento territorial urbano.

Algumas intervenções urbanas, nesse período, reafirmavam o papel de metrópole nacionalizada e cosmopolita, numa perspectiva de planejamento integrado. Medidas foram incluídas no contexto de integração territorial com base nas orientações de redução das disparidades regionais a partir de uma racionalidade hegemônica de induzir o controle da expansão da metrópole carioca. Emblematicamente, esse período fez transparecer as contradições entre as políticas de ordenamento local e as políticas de ordenamento direcionadas ao território nacional, que reforçavam o papel centralizador do núcleo da metrópole em detrimento de uma perspectiva regional.

As políticas de centralização de recursos e atributos pela União permitiram manobras autoritárias do governo federal no ordenamento territorial urbano da metrópole. Na perspectiva da integração do território nacional à luz da ação racional do espaço e da doutrina de Segurança Nacional, a transferência da capital federal para Brasília em 1960 se integrava ao conjunto de medidas centralizadoras do governo federal, acompanhada pelos grandes investimentos de expansão da malha rodoviária no país para a ocupação e o desenvolvimento do interior do país. 
O país encontrava-se em pleno processo de crescimento econômico e desenvolvimento a partir da política de industrialização pautada na substituição de importações. Tal estratégia de ação do governo tinha por base a expansão da infraestrutura física, de forma a criar novos espaços de fluxos acionados pelo vetor científico-tecnológico e de unidades produtivas modernas. $O$ ordenamento do território apoiava-se na lógica de superar os desequilíbrios sociais e econômicos entre regiões de modo que em regiões já constituídas que apresentavam um nível mais elevado de industrialização e urbanização do país como as metrópoles, nas quais os problemas urbanos se avolumavam, a solução partiria das políticas de descentralização industrial e do controle das migrações internas das metrópoles a cargo dos governos estaduais utilizandose de isenções fiscais e renúncia de receitas e do controle do uso e ocupação do solo urbano.

Quando o Estado da Guanabara foi criado em 1960, vigoravam as determinações da Constituição de 1946, de corte descentralizador, que dispunha aos Estados um número maior de recursos próprios ou gerados em seu próprio território; assim como do repasse de recursos da União aos Estados, Distrito Federal e Municípios segundo a população, consumo e produção para financiar investimentos considerados prioritários localmente. Nesse caso, o Estado da Guanabara encontrava-se numa situação favorável pela própria forma como foi constituído valendo-se de receitas que competiam tanto aos Estados quanto aos municípios ou ao que pertencia ao Distrito Federal, assim como the caberia cobrar impostos locais que the conviessem.

Os recursos provenientes dos repasses da União aos municípios concentravam-se no Estado da Guanabara, por ser constituído de um único município. No entanto, como o Estado da Guanabara tornava-se um território eminentemente urbano pela extinção das áreas rurais pelo processo de apropriação acelerada e não planejada urbanização, resultou numa expressiva perda de recursos sobre a propriedade rural de competência dos Estados (Art. 19 da Constituição Federal de 1946), mas, na condição atípica de um Estado constituído de um município, o mesmo arrecadava os impostos de competência dos municípios como o Imposto Predial e Territorial Urbano (Art. 29) referente a todo o território do município, que correspondia ao do Estado. Da mesma forma que os produtos industrializados e direcionados à exportação sofriam 
uma sobretaxa pela cobrança do imposto sobre vendas e consignações que passou a ser denominado de ICM (Imposto de Circulação de Mercadorias) e do imposto sobre exportação, com a Emenda Constitucional No 18 de 1965, esses altos impostos tornaram-se pouco atraentes às indústrias, pois onerava os fluxos de mercadorias e serviços, com sérias consequências financeiras ao Estado.

Da forma atípica, como foi constituído o Estado da Guanabara; segundo sua constituição de 1961, o novo Estado abrigaria os três poderes: executivo, legislativo e judiciário resultante muito mais da força política que o Distrito Federal adquiriu e como medida compensatória às perdas sofridas com a transferência da capital federal. Mudanças ocorreram do ponto de vista políticoadministrativo com a extinção do cargo de prefeito e a instauração do cargo de governador eleito pela população e, na concepção de planejamento urbano baseada na chamada reforma urbana marcada por planos físico-territoriais direcionados à expansão do tecido urbano. As diferentes concepções e interesses políticos entre o primeiro governador eleito do Estado da Guanabara e o presidente da república tornaram-se visíveis nas interrupções das intervenções e da descontinuidade dos planos elaborados ao longo desse período e que impuseram um ordenamento do território com várias consequências sociais e econômicas para a cidade e sua área de influência.

O primeiro governo do Estado da Guanabara ${ }^{51}$ iniciou uma ampla reforma administrativa que visava à descentralização - regional e setorial das tarefas executivas, a implantação de sistemas auxiliares de administração, o adequado grupamento de funções antes dispersas e a distinção entre o nível de planejamento e o de execução. Tal reforma proposta tinha supostamente por objetivo, criar uma máquina administrativa eficiente e capaz de executar o programa de recuperação da cidade do Rio de Janeiro e de viabilização do

\footnotetext{
${ }^{51}$ A eleição de Carlos Lacerda (1960-1965), líder político conservador, contraria a história política da cidade, para primeiro governador do recém-criado Estado da Guanabara. Como primeiro governador buscou um novo destino ao novo Estado a partir de intervenções urbanas relacionadas ao processo de reafirmação do novo Estado com base nas obras públicas de expansão da malha e infraestrutura urbanas subsidiadas por macro política de descentralização interna a partir dos planos viários, do zoneamento do uso do solo, da instalação de indústrias e da adaptação do espaço urbano aos automóveis.
}

[Digite texto] 
Estado da Guanabara proposto pelo governo federal. ${ }^{52}$ Após um longo período de discussão entre políticos e autoridades locais, decidiu-se que o novo Estado não seria desmembrado em municípios e sim em administrações regionais. $O$ Estado da Guanabara foi subdividido em 21 regiões administrativas segundo as características históricas e econômicas dos bairros de modo a dar um suporte administrativo ao governo.

Figura 6 - Estado da Guanabara - Regiões Administrativas - 1

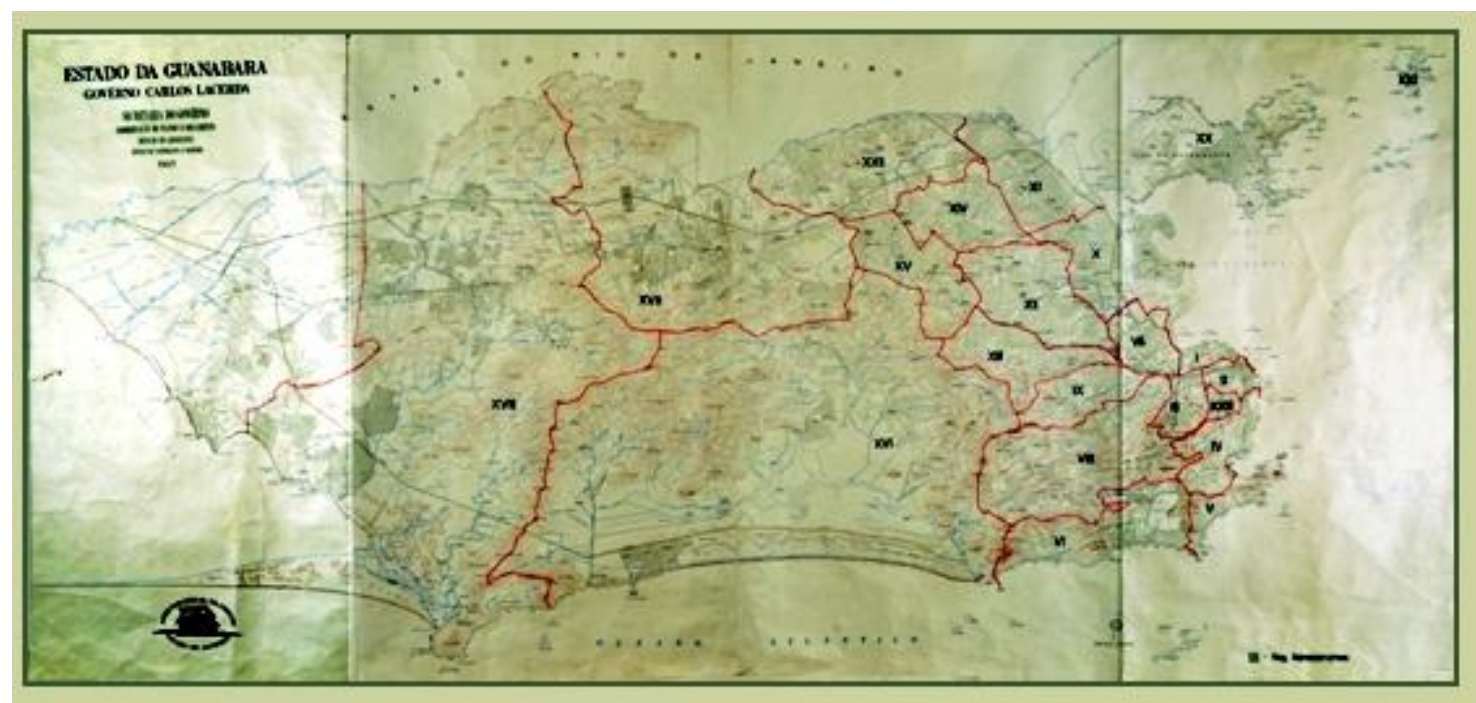

Fonte:ACRJ- Arquivo da Cidade do Rio de Janeiro

As controvérsias políticas reforçaram outras estratégias do primeiro governo do Estado da Guanabara em buscar recursos externos para financiar as obras, em virtude da política de boicote do governo federal, e reforçar a oposição ao governo federal. ${ }^{53} \mathrm{~A}$ ausência do planejamento que priorizasse o

\footnotetext{
${ }^{52}$ A reforma consistia na subdivisão do território do Estado em regiões administrativas, a criação das secretarias de Segurança Pública, de Justiça, de Serviços Sociais, de Serviços Públicos e de Turismo, além da Secretaria do Governo, encarregada da coordenação dos programas do governo e da elaboração da proposta orçamentária e a Secretaria de Finanças que teve seus serviços ampliados e seus órgãos modernizados para atender às novas condições administrativas do Estado. No tocante ao desenvolvimento da produção industrial, o governo criou em 1961 a Companhia Progresso do Estado da Guanabara-COPEG e sua subsidiária COPEG-Crédito de Financiamento.

${ }^{53}$ Os empréstimos externos das agências internacionais de financiamento, em boa parte controlados pelos Estados Unidos, puderam suprir, em alguma medida, a insuficiência dos recursos federais. 0
}

[Digite texto] 
conhecimento profundo do Estado na elaboração das políticas públicas necessárias a amenizar os fortes impactos do crescimento acelerado, a reforma urbana, então implementada, tornou-se uma adaptação do espaço urbano aos meios modernos de investimentos particulares e à ditadura do transporte individual em detrimento de uma política pública direcionada aos grandes problemas que se avolumavam, como o déficit habitacional, a crise econômica e o abandono da política de transporte público de massa.

O arcabouço de leis e normas na época legitimava a adaptação do espaço às edificações modernas e ao uso do automóvel particular com aberturas de logradouros e de parcelamento do solo, defesa das reservas naturais, a preservação de pontos panorâmicos e a manutenção de aspectos paisagísticos. O Decreto No 991 de 1962 incentivou a construção de prédios com maior número de pavimentos que o estabelecido para o local, desde que afastados das divisas e não prejudicassem os locais de interesse paisagístico, histórico ou artístico. A flexibilização das determinações, quanto ao limite de pavimentos dos prédios, foi decisiva para a configuração paisagística da cidade. As áreas mais nobres apresentam intensa verticalização impondo limite máximo à infraestrutura urbana em contraposição das áreas menos valorizadas de baixo valor para o setor imobiliário.

As inúmeras obras viárias que marcaram os dois primeiros governos da Guanabara se justificavam pela criação do Fundo Rodoviário Nacional criado no governo de Juscelino Kubistchek para viabilizar a indústria automobilística, e da utilização de órgãos da administração indireta, entre os quais a Superintendência de Urbanização e Saneamento- SURSAN criada em 1957 e considerada principal órgão da administração pública, quanto ao gasto com

acirrado anticomunismo de Lacerda favoreceu muito o acesso a essas fontes. A vitória da revolução socialista em Cuba, em 1959, implicou uma mudança na política externa norte-americana com relação à América Latina. Logo no ano seguinte, os Estados Unidos propuseram a criação de um Fundo Especial Interamericano para o Desenvolvimento Social a ser aplicado pelo Banco Interamericano de Desenvolvimento (BID) em projetos de reforma agrária, habitação, educação e saneamento básico. Em agosto de 1961, durante a reunião da OEA, foi criado um programa de assistência ao desenvolvimento sócio-econômico da América Latina denominado Aliança para o Progresso. A administração desses fundos norte-americanos competia em sua maior parte à United States Agency for International Development (USAID). A ascensão do "esquerdista" João Goulart à presidência da República reforçou a posição do governador carioca como receptor de recursos oferecidos pelos norte-americanos. Em fevereiro de 1962, o governo da Guanabara conseguiu a liberação de um empréstimo de 34 milhões de dólares pelo BID, para obras de abastecimento e distribuição de água e expansão dos serviços de esgoto.

[Digite texto] 
investimentos nos serviços urbanos e o Departamento de Estradas e Rodagens- DER-GB que recebia suas quotas do fundo. Ambos figuravam como principais responsáveis pelas obras concretizadas que se incluíam não apenas numa perspectiva urbanística, mas de um projeto de desenvolvimento econômico com alteração na inserção da economia estadual no contexto nacional (Santos, 1990).

Embora, o país atravessasse problemas de ordem política e econômica interna e externa no início dos anos 60, as decisões geopolíticas dos Estados Unidos com a América Latina foram essenciais nos recursos para as grandes reformas e obras a que fora submetido o Estado da Guanabara no seu primeiro governo, de Carlos Lacerda, que intencionava ascender no cenário nacional nas eleições presidenciais que estavam por vir. Após a mudança do regime em 1964, o governo do Estado da Guanabara manteve uma afinidade partidária com o governo federal e o fim da instabilidade política permitiu suficientes afluxos de recursos ao Estado a fim de atender aos custos das obras e ao seu principal interesse de candidatura ao planalto que foi em vão, pelo seu tão característico destempero nas relações políticas, até o total aniquilamento dos recursos do governo federal ao Estado e a interrupção das grandes obras.

As medidas centralizadoras do governo militar refletiram nas mudanças nas relações entre governos e no maior controle das finanças públicas. Após o segundo governo eleito da Guanabara, foram introduzidos na administração pública mecanismos de controle do orçamento público do Estado inaugurando um novo estilo de administração, baseado no planejamento aliado ao orçamento público. O orçamento passou a ser um dos principais instrumentos de desenvolvimento do Estado, além de uma reforma administrativa baseada na descentralização do governo do Estado por áreas, uma vez que foi julgado inconveniente dividi-lo em municípios. A princípio, a intenção da descentralização do território em regiões administrativas ainda no primeiro governo do Estado da Guanabara, foi marcada por atos e ocorrências em contradição com a filosofia adotada. 
Figura 7 - Estado da Guanabara - Regiões Administrativas - 2

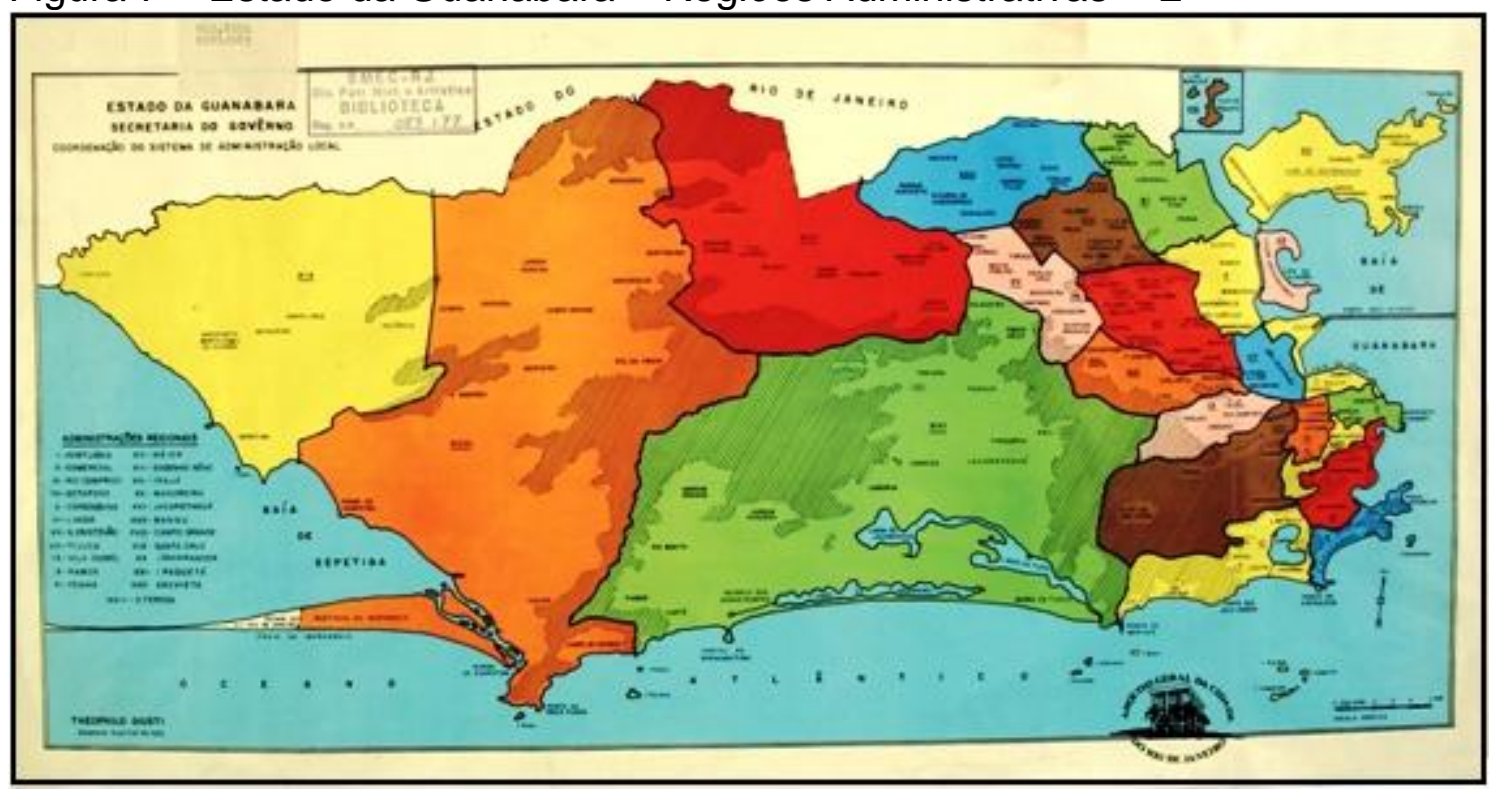

Fonte: ACRJ - Arquivo da Cidade do Rio de Janeiro

A partir do último governo do Estado da Guanabara um novo modelo de administração pública inseria-se no contexto de reformas e experiências importantes consideradas avançadas para a época. $O$ ideário da administração técnica e planejada é implantado no governo do Estado, em contraposição, às práticas anteriores. Alguns instrumentos passaram a fazer parte da administração estadual como o orçamento no intuito de maior controle das receitas e despesas e de realizações de investimentos previstos. A racionalidade seria que a previsibilidade dos investimentos públicos permitiria melhor e mais consciente gasto do erário público numa esfera de planejamento e avaliação; erros seriam corrigidos a tempo. O orçamento passou a ser considerado sinônimo de desenvolvimento para o Estado da Guanabara. Publicações na época se predispunham a avaliar o novo modelo e registravam total despreparo estrutural local quanto a implementação deste novo modelo (Ed. Laudes, 1970, p. 60)

Nessa época as Regiões Administrativas ainda não haviam sido criadas por lei; as verbas não foram descentralizadas, a despeito das várias tentativas nesse sentido; houve permanente beligerância entre dirigentes dos órgãos centrais e as Regiões Administrativas; os órgãos centrais não sofreram a devida redução em suas estruturas, concomitantemente à expansão das Regiões Administrativas; executivas; não foram efetuados levantamentos globais dos problemas e necessidades de cada Região Administrativa; os 
órgãos centrais não expediram normas na proporção necessária e não efetivaram o controle para o seu obrigatório e uniforme cumprimento, nas diversas Regiões Administrativas; os "micro-secretários" regionais não foram completados, e em alguns casos as nomeações recaíram em elementos sem as necessárias qualificações; vários órgãos locais conseguiram livrar-se, total ou parcialmente, da prevista subordinação aos Administradores Regionais, mediante decretos e leis.

Diante de numerosos protestos da sociedade contra a política de remoção das favelas da área mais central da cidade e, os resultados mal sucedidos, o governo decidiu adotar uma política mais conciliatória embora estivesse explícita a não aceitação desses espaços ao contexto urbano. As políticas direcionadas às favelas adquiriram duas orientações: a primeira ratificava o processo de remoção comandada pela CHISAM (Coordenação de Políticas de Habitação de Interesse Social da Área Metropolitana do Rio de Janeiro $)^{54}$ e a segunda de urbanização comandada pela CODESCO (Companhia de Desenvolvimento das Comunidades ${ }^{55}$. As políticas públicas direcionadas às favelas não se inseriam numa perspectiva maior de planejamento urbano e regional, adquiriram um caráter pontual e desconexo do ordenamento territorial urbano. Valladares (2005:p.133) sintetiza o ideário das políticas direcionadas às favelas na cidade:

O regime autoritário acabou por aceitar a CODESCO na medida em que pretendia demonstrar o quanto era capaz de conduzir uma política diversificada: por um lado, graças a algumas raras experiências piloto de urbanização de favelas; por outro, à grandiosa política de remoção que seria desenvolvida em grande escala pela CHISAM, instituição federal criada nessa mesma época. Tratava-se de mostrar que o regime militar era capaz de admitir um certo pluralismo.

\footnotetext{
${ }^{54}$ Instituição federal que tinha por objetivo erradicar as favelas de cidade por reconhecer que as mesmas são construídas de maneira irregular, ilegal fora da normalidade da paisagem urbana onde se situam, não estão integradas ao conjunto normal de habitações da cidade e seus habitantes não pagavam impostos e taxas do ponto de vista da propriedade legal.

55 Órgão do governo estadual criado pelo decreto No 1059/68 com o objetivo de planejar e organizar a recuperação, a reabilitação e o desenvolvimento comunitário das favelas.
}

[Digite texto] 
Em 1965, Negrão de Lima, um opositor de Lacerda, elege-se para o mandato seguinte, o qual se caracterizou pela continuidade da fórmula conciliatória, apesar do contexto de polarização ideológica. De um lado, esse governador determinou a realização de estudos socioeconômicos de viabilidade da urbanização de favelas e implementou-a, em caráter experimental, através da CODESCO, criada em 1968. De outro, no entanto, Negrão de Lima manteve a política de desfavelização da cidade, buscando o apoio, tanto dos moradores de favela, quanto da burguesia e do capital imobiliário, a quem interessava a abertura de novas áreas e as oportunidades de projetos habitacionais de massa, ambos proporcionados pela política de remoção.

O segundo governo de Negrão de Lima do Estado da Guanabara (19651970) deu continuidade à política de remoção das favelas criando a CHISAMCoordenação de Habitação de Interesse Social da Área Metropolitana do Grande Rio, órgão criado pelo governo federal para coordenar as políticas habitacionais da região metropolitana do Rio de Janeiro, baseadas na remoção de favelas em contraposição à CODESCO-Companhia de Desenvolvimento de Comunidades que defendia a urbanização das favelas caracterizando uma pluralidade de políticas do regime militar. No entanto, os conjuntos habitacionais, distantes dos locais de trabalho, elevavam o custo de vida da população mais pobre que era obrigada a ocupar os terrenos de pouco valor ou a optar por moradias na periferia, de menor custo.

O programa de urbanização da CODESCO, visando produzir ações, ditas exemplares, e não criar uma política de massa resumiu-se a três favelas: Brás de Pina, Mata Machado e Morro União. As obras de urbanização foram concluídas, em 1969, e a regularização fundiária foi feita por meio da desapropriação parcial dos terrenos, onde as favelas se assentavam, já que outra parte pertencia à COHAB. A titulação dos moradores foi realizada via contrato de promessa de compra e venda do lote, em que foram reassentados, no novo loteamento, definido para o local. Em virtude da extinção da CODESCO, em 1973, e das descontinuidades administrativas, a escritura definitiva somente veio a ser obtida, na década de 1980, quando essas favelas foram incluídas no Programa "Cada família um lote", já no governo de Leonel Brizola. 
Outro problema percebido foi que o loteamento projetado não se adequava à legislação urbanística vigente, o que impediu a aprovação do mesmo e, consequentemente, o registro das promessas, no cartório imobiliário. Apesar do avanço que representaram, os projetos da CODESCO reproduziram - quadro constante nas políticas para favelas, em que se promove uma dissociação sistemática entre melhorias urbanísticas e instauração de uma legislação urbanística local, o que dá ensejo à permanência da mesma precariedade jurídica, que vigorava anteriormente.

Por outro lado, a criação da CODESCO não logrou desmontar as estruturas jurídicas e administrativas, que viabilizavam a política de desfavelização, não alterando o panorama ideológico, consolidado em torno da ilegalidade das favelas, e da negativa de direitos aos seus habitantes. Assim, poucos meses após a criação da CODESCO, em plena ditadura militar, o governo federal instituiu a Coordenação de Habitação de Interesse Social da Área Metropolitana do Grande Rio- CHISAM, que tinha como objetivo principal acabar com todas as favelas da cidade, num prazo máximo de dez anos, contando, para isso, com apoio político e recursos do $\mathrm{BNH}$.

A CHISAM tratava os morros como espaço urbano deformado e pregava a eliminação completa das favelas, com a justificativa da recuperação econômica, moral, social e higiênica das famílias faveladas. O então governador Negrão de Lima não esboçou qualquer reação. As remoções concentraram-se na zona sul da cidade, atingindo cerca de 130 mil moradores de favelas, que foram removidos para conjuntos habitacionais, nos subúrbios e na zona oeste. Entre os casos emblemáticos de remoção, patrocinados por esse órgão, situa-se o da Favela da Catacumba.

As Associações de Moradores de Favelas são organismos que sofreram várias influências, sendo disputadas, não somente pelos próprios moradores da favela, mas, também, por diversos agentes externos a ela, como militantes partidários, Igreja (através da Fundação Leão XIII) e Estado (através da SERFHA). No caso do Estado, dentre as preocupações, que o levaram a incentivar a sua criação, figuravam evitar o crescimento das favelas (transformando as associações em fiscais), a manutenção da ordem interna e o controle político-eleitoral, tendo sido mais de 75 delas criadas, no início da 
década de 1960, pela SERFHA- Serviço Especial de Recuperação de Favelas e Habitações Anti-higiências), sob a direção do sociólogo Artur Rios.

No entanto, a tentativa de cooptação, segundo alguns relatos, teria "saído pela culatra", uma vez que associações criadas pelo Estado foram dele se distanciando, culminando na criação da FAFEG, em 1963, congregando mais de 70 associações de favelas, a fim de resistir às remoções e lutar pela implementação de serviços públicos. Em um aspecto, pelo menos, registra-se o êxito da política para as Associações de Moradores de favela, desse período: a Secretaria de Serviços Públicos, do Estado da Guanabara, reconhecia apenas a existência de uma associação para cada favela.

Quanto à legislação urbanística do Estado da Guanabara, as decisões tomadas favoreciam o setor de construção civil visando maior aproveitamento do espaço urbano e da infraestrutura urbana instalada. Em destaque, 0 art. 1으 da Lei No 1574 de 1967 que estabelece normas para o desenvolvimento urbano e regional do Estado da Guanabara, dispõe que a referida lei tem por finalidade instituir normas genéricas sobre licenciamento, a execução e a fiscalização de obras, o zoneamento, o parcelamento da terra, as instalações e exploração de qualquer natureza no território do Estado da Guanabara, bem como fixar a natureza dos materiais a serem empregados.

Em conformidade ao ideário de descentralização espacial das metrópoles e modernização, como a do Estado da Guanabara, como solução dos problemas da acelerada urbanização e instalação da indústria automobilística; já no final do primeiro governo foi retomado de fato o Plano Doxíadis ${ }^{56}$ que propunha uma descentralização urbana a ser realizada por um complexo sistema de corredores rodoviários e, ao definir a estrutura multinuclear, possibilitaria a criação de comunidades autônomas e hierarquizadas segundo o tipo de habitação, o uso do solo e as faixas de renda, prevendo uma redução do deslocamento pendular da população pela desfuncionalização da área central da cidade, ou seja: prevendo uma suposta redução da importância dos transportes coletivos e reforçando a inexistência da

\footnotetext{
${ }^{56}$ O Plano Doxíadis foi um plano viário elaborado por técnicos gregos de uma agência de urbanismo chamada Doxíadis Associates na década de 50, cuja execução foi iniciada em 1962 e que visava criar um sistema de vias radiais ligando o centro às diversas regiões do Estado e estabelecer a interligação dessas regiões entre si.
}

[Digite texto] 
área metropolitana em expansão. Em todas as etapas de elaboração do plano, não houve sequer uma consulta à sociedade carioca, inclusive a escolha de uma firma estrangeira se inseriu na visão desenvolvimentista de adesão ao que vem do exterior, em detrimento dos valores nacionalistas e provocou inúmeros protestos nos órgãos de classe dos profissionais ligados ao planejamento urbano. $^{57}$

Figura 8 - O Plano Doxíadis

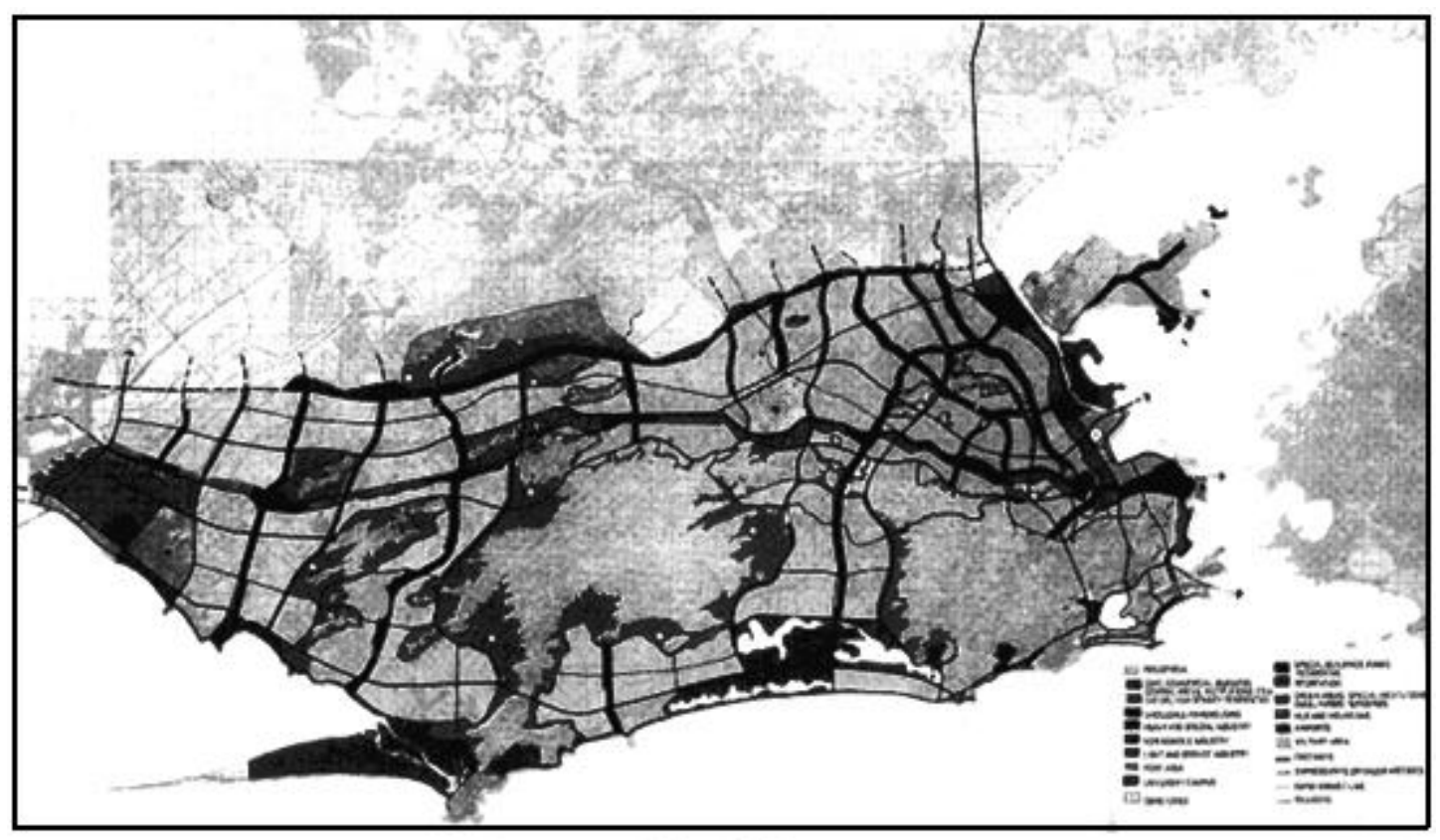

Plano diretor para o ano 2000, Plano Doxiadis, 1965

Fonte: Associates, Consultants on Development and Ekistic. Guanabara Urban Development Plan, Rio de Janeiro, Cedug, 1965

Fonte: wuwumbanidades.arg.br

No entanto, toda expansão prevista no Plano Doxíadis dependia de muitos recursos do poder público pela previsão de indenizações pelas desapropriações, pois as grandes intervenções atingiriam a maior parte do espaço urbano apropriado e consolidado; e pelo emprego de novas

\footnotetext{
${ }^{57}$ Segundo a Revista Clube de Engenharia de 1964, a escolha de um profissional estrangeiro levanta protestos de vários setores. Em reunião de 21 de janeiro de 1964, onde são lidas algumas manifestações, o conselho Diretor do Clube de Engenharia declara que a cooperação técnica estrangeira traduzida em serviços contratados, respeitada a legislação vigente, deve ser apenas supletiva, mesmo assim associada, sempre que possível, à técnica nacional, não se justificando nos casos, como o de planejamento urbanístico, em que tenhamos plenas condições de atender aos requisitos da matéria."
}

[Digite texto] 
tecnologias, o que acarretaria um radical ordenamento da cidade e de sua área de influência. Ao final do primeiro governo, os investimentos previstos mostraram-se muito elevados para o momento de crise e, por não conseguir eleger seu sucessor, também não logrou por em prática o Plano Doxíadis.

A chamada "febre viária", nos dois primeiros governos do Estado da Guanabara, foi a expressão mais perfeita da adaptação dos espaços à indústria automobilística ampliando avenidas, construindo viadutos, abrindo túneis, intensificando as obras do metrô e a inauguração da ponte Rio-Niterói no último governo. As consequências foram diversas, como o fim de antigos bairros terminais, convertidos em áreas de passagem, a queda de qualidade de vida pela intensificação do tráfego, além dos impactos visuais e paisagísticos da cidade com a construção de verdadeiros corredores de tráfego, principalmente, concentrados nas zonas central e sul da cidade, que ao longo dos anos concentraram os maiores intervenções espaciais.

Ao longo desse período de governo foi elaborado o Plano de Habitação Popular, amplamente financiado pelo governo norte americano através da Aliança para o Progresso, propondo a urbanização de áreas destinadas à construção de casas populares para a viabilização de um programa de remoção de favelas, para o descontentamento da maior parte da população favelada. Os conjuntos habitacionais, construídos para a população favelada, por sua vez, eram desassistidos de uma infraestrutura de bens e serviços além de distantes dos locais de trabalho dessa população, fato que gerava um custo muito elevado para o deslocamento e resultou no retorno de ocupação dos morros e encostas da cidade.

Por sua vez, as medidas de contenção do governo federal na época, visavam combater o déficit público, reduziram o crédito ao setor privado e, contiveram o aumento de salários a ponto de atingirem mais diretamente 0 setor industrial (vestuário, alimentos e construção civil), dependente de crédito barato, de subsídios governamentais e do consumo da população de baixa renda, que formavam a base industrial carioca. A crise econômica que se estabeleceu no Estado da Guanabara se agravou mais com a drástica redução do Imposto de Vendas e Consignação, pela queda do volume de vendas. 
A incompatibilidade política entre o governo estadual e o governo federal, a redução dos recursos ao Estado ${ }^{58}$, as medidas rigorosas de controle fiscal e salarial, a adoção de medidas autoritárias, conduziram a um drástico desempenho econômico, ao aniquilamento da construção de sua identidade política e pretensa autonomia com a interferência do governo federal nas decisões políticas e econômicas locais.

A sobreposição dos planos, leis e normas urbanísticas resultaram numa estruturação da área metropolitana, composta por um núcleo hipertrofiado, concentrador da maioria da renda e dos recursos urbanísticos disponíveis, cercado por estratos urbanos periféricos cada vez mais carentes de serviços de infraestrutura, à medida que se afastam do núcleo, sem nenhum comprometimento político com o restante de sua região metropolitana.

Foi um período conturbado pelas mudanças de regime político no país, de conflitos políticos entre representantes locais e o governo federal, de sobreposição de planos urbanísticos, leis e normas segundo princípios de modernização do espaço urbano, de políticas de erradicação das favelas das áreas centrais, do papel intervencionista do governo federal nas políticas de consolidação da metrópole, que contribuíam para um quadro complexo. A sobreposição de órgãos dos governos federal, estadual e municipal; além de instituições assistenciais religiosas contribuíram nas políticas sociais descontextualizadas de um ideário comum de ordenamento do território metropolitano. (Vide Anexo C)

No auge do autoritarismo do governo militar de Geisel, foi decretada a fusão entre os dois Estados e a institucionalização da Região Metropolitana do Rio de Janeiro segundo a Lei Complementar No 20 de 1974. Tal medida acarretou inúmeras alterações político-administrativas, com a extinção do cargo de governador do Estado da Guanabara e a criação do cargo de governador do novo Estado do Rio de Janeiro e da criação do cargo de prefeito do novo município do Rio de Janeiro, assim como da organização normativa do novo

\footnotetext{
${ }^{58}$ Com o progressiva deterioração das relações dos Estados Unidos com os governo de Jânio Quadros e João Goulart, o presidente John Kennedy suspendeu todas as verbas da Aliança para o Progresso que pudessem ser utilizadas para financiar o déficit público e a embaixada norte americana passou a firmar acordos somente com governadores e prefeitos simpáticos à posição dos Estados Unidos.
}

[Digite texto] 
Estado e do município nas políticas de ordenamento de seu território, com a promulgação em 1975 de nova Constituição do Estado do Rio de Janeiro.

O discurso de decadência econômica atribuído ao Estado da Guanabara e a crise econômica instalada no país, serviram de base para que o governo federal decidisse pela fusão dos dois Estados, no contexto das medidas autoritárias. Segundo Santos (1990), tal decisão pela fusão dos dois Estados, evidentemente, excluía a Guanabara dos benefícios das políticas de indução ao desenvolvimento industrial e, pior, confundia a situação econômica do Rio de Janeiro, em processo de esvaziamento há décadas, com a de São Paulo. Portanto, no início dos anos 1970, nem a administração Chagas Freitas contava com meios de manter os investimentos públicos, nem o governo federal tinha a Guanabara como prioridade na alocação de seus dispêndios.

A Fusão dos dois Estados foi resultado do que se tinha disposto no II PND, de atenuar desníveis regionais de desenvolvimento industrial entre os dois Estados, procurando compatibilizar os movimentos de descentralização com a preservação de escalas de produção econômica e de economias de aglomeração. Especificamente, a fusão para o novo município do Rio de Janeiro significou restrição aos reduzidos impostos municipais e consequentemente, redução da capacidade administrativa de bens e serviços públicos que ultrapassavam seus limites territoriais.

Embora a perda do dinamismo econômico do Estado da Guanabara estivesse ligada às questões políticas, sociais e econômicas desde a década de 50, tal argumento foi utilizado pela classe empresarial e o governo como justificativa para a fusão $0^{59}$. Muitos políticos se opuseram a tal medida afirmando que um Estado rico como o da Guanabara tornar-se-ia um município pobre. Alguns documentos reconhecem as dificuldades de ordem econômica e política que envolviam a institucionalização da Região Metropolitana do Rio de Janeiro diante de uma área sujeita a duas jurisdições estaduais distintas, mas, aponta a medida como a única solução para o Rio de Janeiro diante da realidade dos

\footnotetext{
${ }^{59}$ Grande parte dos empresários cariocas representados pelos órgãos oficiais do CIRJ-Confederação das Indústrias do Rio de Janeiro, FIEGA- Federação das Indústrias do Estado da Guanabara e o IDEGInstituto de Desenvolvimento do Estado da Guanabara, faziam parte de diferentes organizações com destaque o IPES- Instituto de Pesquisa e Estudos Sociais cujos estudos serviam de base para as ações do governo federal a favor da fusão.
}

[Digite texto] 
problemas metropolitano que se avolumavam. Nenhum estudo anterior de viabilidade foi desenvolvido prevendo a fusão entre duas unidades federativas distintas. Constata-se diminuto avanço político-institucional quanto à Região Metropolitana do Rio de Janeiro com a criação do GERMET- Grupo de Estudo da Região Metropolitana do Rio de Janeiro, que atuava junto à Secretaria Geral do MINTER. O ideário do planejamento físico-territorial comandado pelo governo federal na época se sobrepôs às características singulares locais e regionais.

Assim, a fusão entre os dois Estados passou a ser discutida por representantes políticos e grupos representativos influentes nas decisões políticas locais e nacionais, sem uma prévia consulta à sociedade, apesar da barreira institucional que separava o núcleo de sua periferia. Concomitante a essa discussão, a institucionalização das regiões metropolitanas tornou-se prioridade nacional com base na acelerada urbanização do país e no reconhecimento das limitações político-administrativas das áreas metropolitanas nas demandas de bens e serviços públicos à população.

As restrições financeiras e políticas à autonomia estadual, impostas pelo governo federal, tornaram imprescindível que a administração estadual reorientasse sua atuação. O último governo de Chagas Freitas (1970-1975) indicado pelo governo militar foi marcado pela institucionalização de entidades voltadas para o planejamento mudando o funcionamento da administração estadual com a substituição em 1971 da Secretaria de Governo pela Secretaria de Planejamento e Coordenação Geral e a criação de outros órgãos ligados aos setores de bens e serviços.

Foi criado o Conselho de Desenvolvimento Econômico-CDE em 1972, encarregado de orientar a política de desenvolvimento de orientar a política de desenvolvimento de seu governo, o Fundo de Desenvolvimento EconômicoFUNDEC, subordinado à Companhia Progresso do Estado da Guanabara COPEG, voltado para financiar os projetos considerados prioritários pelo CDE, e a criação do Conselho de Planificação Urbana, subordinado à Secretaria do Planejamento.

A fusão entre o Estado da Guanabara e o antigo Estado do Rio de Janeiro e a institucionalização da Região Metropolitana do Rio de Janeiro realizada em 1975 inseria-se na política de desenvolvimento urbano no sistema [Digite texto] 
de planejamento nacional. Tinha por base a geração, difusão e adaptação de inovações que se processariam ao longo do tempo em determinados pontos do território, principalmente nas aglomerações urbanas, valendo-se das diferenças locais baseadas na capacidade de gerar, aplicar e irradiar as inovações pelo território que gerariam outros pólos sucessivamente. $\mathrm{O}$ ordenamento territorial seria baseado no processo contínuo de equilíbrio e desequilíbrio dos pólos de desenvolvimento.

O governador do novo Estado, o Almirante Floriano Faria Lima ${ }^{60}$, indicado pelo governo federal, reconheceu no documento das diretrizes de sua administração as disparidades de recursos entre a metrópole e suas periferias provenientes dos fluxos de trabalho, capital, mercadorias e serviços. Seria urgente eliminar as barreiras assim como, necessário fortalecer o segundo pólo industrial do país. A partir da captação de recursos diretos das instituições financeiras mundiais, a prioridade do governo federal foi supostamente concretizar a Fusão entre os dois Estados com investimentos diretos em obras que supostamente proporcionariam a integração econômica e territorial do novo Estado.

No entanto, no contexto dos grandes investimentos propagados pelo II PND com base no elevado crescimento econômico, o governo federal na época deu continuidade na política de distritos industriais em todo o Estado do Rio de Janeiro, em detrimento da cidade do Rio de Janeiro, que não internalizou nenhum sistema industrial integrado e que passou a apresentar problemas estruturais que se agravaram posteriormente nos anos de 1980, com a

\footnotetext{
${ }^{60}$ Empossado em 15 de março de 1975, conseguiu obter do governo federal o apoio financeiro para a realização da fusão. Em julho do mesmo ano, o presidente da República Ernesto Geisel assinou vários atos para ativar o desenvolvimento do novo Estado. A Região Metropolitana do Rio de Janeiro (Grande Rio) recebeu recursos de quatrocentos milhões de cruzeiros e teve um organismo criado para tratar do planejamento das questões de seu interesse - a Fundação para o Desenvolvimento da Região Metropolitana do Rio de Janeiro (Fundrem). A Companhia Estadual de Águas e Esgotos (CEDAE) recebeu também financiamento de quatrocentos milhões de cruzeiros do Banco Nacional da Habitação (BNH) para a execução, ampliação e melhoria dos sistemas de abastecimento de água da Baixada Fluminense, da região dos Lagos, de Niterói e de São Gonçalo. $O$ Banco do Brasil concedeu empréstimo de 50 milhões de cruzeiros para o levantamento aerofotogramétrico da cidade do Rio de Janeiro.
} 
exaustão do modelo de desenvolvimento econômico e social. A própria ausência de articulação física, política e administrativa entre o município do Rio de Janeiro e sua respectiva região metropolitana desencadeou uma perda expressiva das indústrias cariocas e fluminenses para outros Estados e regiões no chamado "esvaziamento do Rio".

O ordenamento do território do novo Estado do Rio de Janeiro foi a expressão mais nítida da reprodução dos padrões federais ao nível estadual. Definia-se como prioridade a forma de governar dos Estados baseada em planejamento operante, considerando as singularidades locais da realidade administrativa, econômica, social e política com destaque para o trabalho desenvolvido pela CEDES- Conselho Estadual de Desenvolvimento Econômico e Social. O conselho não considerava a dimensão espacial nas suas diretrizes para o desenvolvimento do Estado do Rio de Janeiro e as dificuldades de regionalização a partir do planejamento regional reforçavam os obstáculos para uma maior integração entre o pólo e a região polarizada por questões políticas, históricas e ideológicas.

O I Plano de Desenvolvimento Econômico e Social do Estado do Rio de Janeiro 1976/1979 ${ }^{61}$ representou um programa definido de governo para a concretização da fusão dos dois Estados e evidenciou a incorporação dos padrões de planejamento nacional na esfera estadual. O plano previa que determinadas condições mínimas deveriam ser cumpridas, como a continuidade do apoio do governo federal, em termos de recursos financeiros e humanos, apoio dos poderes do Estado, municípios e setor privado às prioridades e diretrizes da política de desenvolvimento e a consolidação integral do modelo administrativo institucionalizado pelo governo. Foi criado pelo Decreto-Lei No 8 de 1975 no contexto das transferências dos recursos federais o FUNDES- Fundo de Desenvolvimento Econômico e Social, que tinha como finalidade o financiamento de programas e projetos prioritários em

\footnotetext{
${ }^{61}$ Os objetivos do plano eram: propor a elevação do nível da qualidade de vida da população através da consolidação do segundo polo nacional de desenvolvimento, maior integração setorial e espacial da economia, a partir das potencialidades, vocações e problemas de cada região, materialização de projetos empresariais que aproveitem as vantagens comparativas no território, instrumentos institucionais criados ou fortalecidos pelo governo estadual no sentido de apoio aos projetos empresariais, reconhecimento do setor público estadual como agente do processo de desenvolvimento (Brasileiro, 1979).
}

[Digite texto] 
setores estratégicos para o desenvolvimento econômico e social do Estado entre outros recursos, reforçando a dependência dos repasses do governo federal e a vulnerabilidade do novo Estado.

As ações públicas estiveram voltadas para a efetivação da fusão entre os dois Estados antagônicos sob aspectos políticos, sociais, históricos e econômicos. Toda política pública passou a se direcionar para a Região Metropolitana do Rio de Janeiro conciliando as administrações entre os dois Estados. As leis e normas urbanísticas, elaboradas nesse período após a fusão, ratificam o processo de exclusão social no espaço urbano com 0 crescimento em quantidade e extensão das favelas e a intervenção do governo no ordenamento territorial urbano de modo a dar continuidade à política de não reconhecimento público destes espaços no contexto urbano, em benefício dos interesses do setor imobiliário responsável pela aquisição, ocupação e uso, desapropriação das terras urbanas no processo de expansão urbana.

Segundo Gonçalves (2000:194-195) a política de erradicação das favelas seria juridicamente possível valendo-se do art.124 da Constituição do Estado do Rio de Janeiro, de 1975, que previa a intervenção pública nas favelas, sobretudo expropriando imóveis considerados abandonados. Um fato muito interessante pôs fim à política de erradicação das favelas quando no governo do prefeito Marcos Tamoio (1975-1979), utilizando-se do discurso de perigo iminente à vida dos habitantes da favela do Vidigal ${ }^{62}$, intencionou uma importante operação imobiliária com a erradicação da favela do Vidigal em 1977, mas, que não se efetivou pelo simples fato de o município não ter provado o processo de erosão do solo nesse morro.

Muitos recursos da União foram direcionados ao novo Estado para que de fato se concretizasse a fusão e viabilizasse as políticas regionais direcionadas à Região Metropolitana do Rio de Janeiro. O ideário do planejamento metropolitano, a princípio seria implementado utilizando-se dos órgãos estaduais e municipais e a infraestrutura existente para executar programas de âmbito regional, almejando evitar a duplicação e a concorrência de esforços e o desperdício injustificável de recursos, num sistema rigoroso de

\footnotetext{
${ }^{62} \mathrm{O}$ exemplo citado da Favela do Vidigal demonstra os grandes conflitos políticos que cercam favelas que se localizam em áreas nobres da cidade e que são alvos de diversas tentativas de remoção ou de desapropriação pelo governo ao longo da história.
}

[Digite texto] 
gastos públicos. No entanto, sem os necessários avanços institucionais e as definições das competências das esferas do governo diante de uma nova forma de planejamento que tentava se concretizar, muitas dificuldades foram surgindo, inviabilizado a proposta inicial.

A fim de consolidar a fusão e a gestão da região metropolitana, os esforços estiveram voltados para uma política de integração entre os três níveis de governo, que ratificavam a orientação federal da política urbana, a reorganização administrativa encaixada aos planos e organizações federais, a influência direta da indústria da construção civil no ordenamento do território e das empresas imobiliárias no ambiente crescente de conflitos de interesses de grupos sociais representativos que se organizavam.

Destacamos modelos de atuação dos três níveis do governo no desenvolvimento da política urbana após a Fusão dos dois Estados e a abertura da participação de entidades representativas da sociedade na discussão dos rumos do desenvolvimento urbano. Algumas medidas do governo federal foram fundamentais na elaboração da política urbana como a criação do FNDU- Fundo Nacional de Desenvolvimento Urbano, a Lei de Desenvolvimento Urbano, a atuação da CNPU/CNDU, do Ministério do Interior, do $\mathrm{BNH}$, assim como outros modelos de atuação do governo estadual, em destaque a Fundrem e a Fundação Leão XIII e o modelo de atuação do governo municipal, a partir de órgãos, posicionamento político e planos elaborados. A cidade do Rio de Janeiro e sua respectiva região metropolitana tornaram-se locais de intervenções segundo modelos de atuação do governo que se sobrepuseram no ordenamento de seu território.

Diante da realidade metropolitana no país, como um desafio lançado aos Estados, sem os necessários avanços institucionais cabíveis à administração das regiões metropolitanas, a proposta do planejamento metropolitano em conciliar interesses, entre as esferas do governo, manifestados pelos representantes dos grupos sociais, reflete o conflito de interesses políticos na sociedade, expressos espacialmente nas políticas de ordenamento do território. Gerir metrópoles se tornou um grande desafio pelos inúmeros problemas que ultrapassavam os limites político-administrativos como a demanda crescente por habitação, saúde, educação, serviços básicos como abastecimento d'água e coleta de esgoto, transportes, entre outros.

[Digite texto] 
No entanto, nesse período marcado pela centralização de poder no governo federal fez com que Estados e municípios se tornassem dependentes dos repasses de recursos do governo para gerir as grandes concentrações urbanas e reforçou de certa maneira a intervenção e controle do governo federal sobre as regiões metropolitanas em que os conflitos institucionais e a constituição política, histórica, social e territorial da Região Metropolitana do Rio de Janeiro dificultaram a concretização das intenções do governo.

De modo a caracterizar uma nova forma de planejamento urbano baseado nas regiões metropolitanas, o governo federal criou a CNPUComissão Nacional de Regiões Metropolitanas e Política Urbana, pelo Decreto Lei No 74156 de $1974^{63}$, e que pertencia à SEPLAN-PR Secretaria de Planejamento da Presidência e tinha por finalidade, implantar o sistema de regiões metropolitanas e propor diretrizes, estratégias e instrumentos da Política Nacional de Desenvolvimento Urbano. A política de metropolização de ações urbanas era resultado da principal linha de ação da CNPU- Comissão Nacional de Política Urbana, criada em 1974, um ano anterior à fusão, e foi considerada prioridade pelo governo Faria Lima, ao instalar o CEDESConselho Estadual de Desenvolvimento Econômico e Social.

Os principais feitos da CNPU foram: orientar a política de utilização do solo urbano e o planejamento dos sistemas de transportes, além de ser responsável pela aprovação dos orçamentos das companhias construtoras dos Metrôs do Rio e São Paulo e pela participação da União nesses projetos, e da formulação do anteprojeto da Lei de Desenvolvimento Urbano que reformulou o direito de construir, adequou à função social da propriedade e a remuneração do "solo criado" como meios propostos para o governo ordenar o espaço urbano das cidades. A primeira tentativa da CNPU em criar uma Lei Nacional de Desenvolvimento Urbano em 1977 teve por objetivos primordiais a melhoria da qualidade de vida, a distribuição espacial dos contingentes populacionais, a

\footnotetext{
63 Inicialmente a CNPU era integrada inicialmente pelo Secretário-Geral da Secretaria de Planejamento da Presidência da República, SEPLAN-PR, na qualidade de Presidente; Secretário-Geral do Ministério do Interior, na qualidade de Vice-Presidente; Presidente do Banco Nacional de Habitação-BNH; representante do Ministério dos Transportes; representante do Ministério da Fazenda; representante do Ministério da Indústria e Comércio; e quatro membros escolhidos conjuntamente pela SEPLAN-PR e pelo Ministério do Interior. Desta forma, com esta composição, procurava-se uma melhor integração das ações do governo no campo do desenvolvimento urbano.
}

[Digite texto] 
integração dos sistemas urbanos nacional e regional, a preservação do meio ambiente e do patrimônio histórico cultural, arqueológico e paisagístico.

Ao fim do governo de Geisel, em 1979, e com a posse do General João Figueiredo na Presidência da República, mudanças ocorreram no governo do Estado e na prefeitura, assim como significativamente no estilo de governo e de política social e urbana, apesar da orientação do mesmo sentido. Os conflitos urbanos quanto ao acesso da população de baixa renda tornavam-se mais frequentes e uma significante mudança no referencial das políticas públicas extinguia o processo de remoção das favelas para a sua efetiva consolidação na cidade. A suposta incorporação da participação da sociedade na formulação das políticas urbanas criava um aspecto mais democrático nas decisões políticas, embora envolta de conflitos de interesses entre diferentes grupos. As mudanças estiveram muito mais ligadas na implementação das políticas orientadas pelo III PND que definiam políticas públicas direcionadas à população de baixa renda e às políticas de transportes das regiões metropolitanas.

No governo de João Figueiredo, a CNPU foi retirada da SEPLAN e ligada ao MINTER como CNDU - Conselho Nacional de Desenvolvimento Urbano. A questão urbana em sua complexidade, em pleno período de centralização de recursos e de decisões do governo federal, refletiu a incapacidade dos Estados e municípios em gerir suas cidades e regiões metropolitanas sem a intervenção do governo federal nas decisões locais. Segundo Poggiese (1985:104) a transformação da CNPU em CNDU significou elevar a questão urbana a um nível interministerial, com atribuições mais executivas, essencialmente na distribuição de financiamento para programas urbanos.

O CNDU foi um órgão normativo presidido pelo Ministro do Interior, tendo como membros os secretários-gerais dos Ministérios do Interior, do Planejamento e da Indústria e do Comércio, os presidentes do $\mathrm{BNH}$ e da EBTU-Empresa Brasileira de Transportes Urbanos e outros três nomeados pelo Presidente da República. A Comissão tinha como atribuições: propor diretrizes, estratégias, prioridades e instrumentos da política urbana, e elaborar os programas anuais e plurianuais de investimentos, a programação de apoio financeiro ao desenvolvimento urbano e estabelecer a programação anual do [Digite texto] 
FNDU - Fundo Nacional de Apoio ao Desenvolvimento Urbano, e de outros recursos, a serem despendidos diretamente pela União ou transferidos aos Estados, Distrito Federal e municípios, especialmente os relativos à habitação, saneamento, áreas industriais, transporte e administração metropolitana e municipal.

No contexto de atuação de órgãos ligados ao CNDU, como o MINTER e o $\mathrm{BNH}$, na política de desenvolvimento urbano visavam supostamente atender às necessidades da população de baixa renda a partir de programas e projetos especiais de desenvolvimento com outros órgãos federais, estaduais e municipais e instituições privadas buscavam maior integração de esforços e de recursos com relação às atividades desenvolvidas nessa área. Por decisão do MINTER, o BNH coordenou o PROMORAR ${ }^{64}$ em âmbito nacional e dentro do PLANHAP- Plano Nacional de Habitação Popular em parceria com agentes financeiros, bancos oficiais e estabelecimentos de crédito e promotores como os Estados, municípios, COHAB e órgãos assemelhados. Os objetivos principais do programa eram a erradicação das sub-habitações e a melhoria das áreas sujeitas às inundações sob responsabilidade do DNOS.

A articulação institucional que se efetivou em 1979 sobre as bases do Projeto do Ministério do Interior contou com a participação de representantes do Departamento Nacional de Obras e Saneamento - DNOS, da SERSESecretaria Especial do Ministério do Interior para a Região Sudeste, da Secretaria de Obras do Estado do Rio de Janeiro, das Secretarias Municipais de Planejamento e de Obras e Serviços Públicos da Prefeitura do Rio de Janeiro, da FUNDREM- Fundação para o Desenvolvimento da Região Metropolitana do Rio de Janeiro e do BHN-Banco Nacional de Habitação. Resolveu-se criar um grupo de trabalho específico e permanente para elaborar a política de desenvolvimento urbano e de uso do solo na região. A nomeação do grupo de trabalho era competência do Ministro do Interior e seria operacionalizada através de um protocolo de intenção subscrito entre os três

\footnotetext{
${ }^{64}$ O PROMORAR foi um programa do governo federal de urbanização das favelas e pioneiramente buscava incorporar o trabalho comunitário ao planejamento dos projetos habitacionais a fim de reduzir qualquer resistência dos favelados aos projetos e aumentar a eficácia do programa. A idéia principalmente era reafirmar o papel do BNH que teve a sua imagem atrelada aos programas ineficazes de moradia a população de baixa renda anteriormente.
}

[Digite texto] 
níveis institucionais correspondentes. O compromisso entre o Governo Federal, representado pelo MINTER; o Governo Estadual e a Prefeitura do Rio de Janeiro foi assinado a 15 de junho de 1979, com a finalidade de elaborar um Projeto de Recuperação das Áreas Alagadas na Baía de Guanabara, nomeando ao mesmo tempo a Comissão responsável pela tarefa.

Integraram o grupo de trabalho representantes do $\mathrm{BNH}$, Secretarias Estaduais de Obras e de Planejamento, o Município do Rio e DNOS, ficando a cargo deste último a coordenação. A supervisão era exercida pelo CNDUConselho Nacional de Desenvolvimento Urbano, que era também representado no referido grupo. Os organismos atuavam em definidas áreas como o $\mathrm{BNH}$, financiando as obras; o DNOS, executando as obras de saneamento da orla marítima, dragando e aterrando uma faixa do mar; a SERSE- no planejamento regional, a FUNDREM, nos aspectos de desenvolvimento urbano e a Prefeitura no apoio aos projetos locais.

No caso específico da região Sudeste, que não se integrava a nenhuma das Superintendências de Desenvolvimento Regional do Ministério do Interior, recebeu um tratamento diferente das demais regiões cujas prioridades conferidas ao desenvolvimento regional estiveram relacionadas aos projetos de desenvolvimento urbano, em especial de habitação e saneamento básico através do BNH e de saneamento geral, sob responsabilidade do DNOS. No planejamento regional a SERSE representou as ações do MINTER no Rio de Janeiro elaborando políticas públicas a fim de desconcentrar as regiões metropolitanas e controlar os fluxos migratórios à região metropolitana intensificando a criação de núcleos urbanos de compensação direcionando investimentos nas cidades médias externas à Região Metropolitana do Rio de Janeiro.

A atuação do Ministério do Interior via BNH no ordenamento do território da Região Sudeste tinha por intenção a política de emprego com amplos reflexos na melhoria da distribuição de renda e na capacitação de recursos humanos e, os programas de desenvolvimento urbano tinham em vista as diretrizes da CNPU ao desenvolvimento das cidades de médio porte como consequência da necessidade de se reduzir as taxas de crescimento do Grande Rio e Grande São Paulo, reduzindo a transferência de pessoas do meio rural para as cidades. As ações do MINTER na Região Sudeste e Sul 
consideradas as mais desenvolvidas assumiram características diferentes das demais regiões.

A concepção do ordenamento territorial para o governo brasileiro compreendia promover a organização da rede urbana em um sistema que satisfizesse as aspirações dos habitantes das diferentes regiões do país, e traria como consequências a reorientação dos fluxos migratórios, através da orientação dos investimentos públicos e privados em sintonia com os objetivos de desenvolvimento regional; e iniciaria um processo de descompressão urbana, reorientando investimentos para induzir o crescimento das cidades médias e núcleos interiorizados. Assim, o foco de ação do governo federal através do CNDU era o fenômeno urbano, portanto a decisão de conduzir o desenvolvimento de modo integrado, formulando uma política urbana que refletisse a estratégia global de crescimento e transformação social. Outra questão levantada pela política urbana dizia respeito à pobreza que se acumulava nas periferias urbanas, devendo ter ação concentrada no campo e na cidade; incentivos ao desenvolvimento da agricultura, aumentando os níveis de produção e de produtividade, valorizando a vida rural, enfatizando os pequenos e médios produtores, deveria contribuir para diminuir a migração rural-urbana.

Na Região Sudeste, a ação de desenvolvimento regional foi inicialmente coordenada pela REMI - Representação do Ministério do Interior no Rio de Janeiro, substituída pela SERSE- Secretaria Especial da Região Sudeste, pelo Decreto No 83.839 de 1979, cuja a principal finalidade de sua criação foi dar à Região Sudeste um órgão capaz de encaminhar, coordenar e supervisionar as ações do Ministério do Interior nessa região, de uma forma descentralizada a fim de proporcionar um equilíbrio do desempenho econômico e um controle das migrações sobre o território (Anexo D). Os programas desenvolvidos e/ou acompanhados pela SERSE tinham o objetivo de implantar infraestrutura nas sub-regiões menos desenvolvidas de cada Estado que compõem a Região Sudeste e que sofreram degradação de seu meio ambiente pelas atividades econômicas extrativas praticadas no passado ou que praticavam atividade extrativa dependente de apoio técnico e financeiro como o PRODENOR Programa Especial do Norte Fluminense. 
Quanto ao Desenvolvimento Urbano, a SERSE buscava acompanhar a execução das políticas e diretrizes estabelecidas pelo Conselho Nacional de Desenvolvimento para a Região Sudeste, fornecendo subsídios para a elaboração, em nível estadual e municipal, de programas e projetos de apoio às capitais e cidades de porte médio, mantendo convênios com os quatro Estados, promovendo e acompanhando a execução de projetos, obras e serviços, nos setores de planejamento, administração e saneamento básico. Os Programas de Desenvolvimento Urbano direcionados para as cidades de porte médio refletiam a política geral do governo federal de organização territorial e desenvolvimento do país a partir do fortalecimento de pontos no território nacional, o estímulo à desconcentração das atividades econômicas e da população, criando novas oportunidades de emprego e reduzindo as disparidades inter-regionais e interpessoais de renda, devendo finalmente conduzir à interiorização do desenvolvimento nacional.

A classificação de "Cidades de Porte Médio" era determinada pela sua população, importância sócio-econômica, função regional significativa e potencial capaz de incrementar o desenvolvimento de sua região de influência. Os programas procuravam reforçar as potencialidades das cidades de porte médio a partir de intervenções nos sistemas econômico, social e físicoterritorial, com investimentos voltados para a expansão da infraestrutura física, serviços urbanos e comunitários, urbanismo e para a geração de novos postos de trabalho. A idéia visava ao desenvolvimento e diversificação da economia urbana, cujos benefícios atingiriam os setores formal e informal principalmente em áreas de baixa renda, a partir da elaboração do perfil da cidade, definição de estratégias de intervenção e propostas de anteprojetos, da elaboração dos projetos executivos através das unidades executoras municipais, estaduais ou federais e de implantação dos projetos.

Programas de Assistência aos Municípios tinham por objetivo principal proporcionar às prefeituras recursos destinados à execução de serviços reconhecidamente prioritários como obras de saneamento, implementação dos serviços de abastecimento de água, infraestrutura urbana, de telefonia entre outros. Programas de Desenvolvimento de Comunidades promoviam e acompanhava a execução de projetos de cunho social, como implantação de centros comunitários rurais e urbanos, organização de comunidades faveladas, 
projetos de pesquisa de participação e integração de populações, aquisição de equipamentos, implantação de micro-produção, organização de grupos de artesãos.

No caso específico da Cidade do Rio de Janeiro a atuação da SERSE em convênio com a Fundrem - Fundação para o Desenvolvimento da Região Metropolitana do Rio de Janeiro apoiou-se nos programas municipais de educação, saúde e desenvolvimento social das populações faveladas e a partir do convênio entre a Fundrem e as prefeituras municipais para promover a urbanização de suas áreas, visando à legalização das terras. Programas de Assistência Técnica Municipal voltavam-se para o reforço da capacidade de planejamento das prefeituras municipais, especificamente para a elaboração de Planos de Desenvolvimento Físico-Territorial.

No contexto das ambições presidenciais do Ministro do Interior Mario Andreazza, muitos recursos foram levantados com as instituições financeiras mundiais para as intervenções do governo federal na cidade com o apoio inicial do governador Chagas Freitas ${ }^{65}$. No contexto das discussões da habitação para fins sociais e a consolidação das favelas no espaço urbano da cidade a partir da atuação do BNH e da participação da SERSE, o Projeto Rio conhecido por PROMORAR, em 1979, ${ }^{66}$ consistiu na urbanização local, com a construção de moradias de baixo custo em substituição das palafitas e a implantação de uma infra-estrutura local. Tal programa demonstrou maior flexibilização das normas estritas do BHN com relação ao ordenamento do espaço e o tipo de moradia financiada pelo banco. A Fundrem - Fundação de Desenvolvimento da Região Metropolitana tomou o projeto com a intenção de recuperação da área alagadiça pela drenagem do solo, o ordenamento urbanístico da região e o aterramento de parte de uma área próxima à Baía de Guanabara para alocar os habitantes dos barracos construídos sobre pilotis.

\footnotetext{
${ }^{65}$ Inicialmente o PROMORAR teve apoio do governo estadual de Chagas Freitas muito pela sua política de não confronto com os interesses do regime militar. No entanto, com o fim do bipartidarismo, Chagas Freitas não sendo aceito inicialmente pelo novo PMDB por causa de sua conivência com os militares, afiliou-se ao PP Partido Popular. Após a incorporação deste partido pelo PMDB em 1981 e a afiliação de Chagas Freitas à este partido, o diálogo entre o governo estadual e federal ficou abalado e o projeto foi tocado apenas pelo governo federal.

${ }^{66}$ O PROMORAR tinha em vista o ordenamento do conjunto de seis favelas: Timbau, Baixa do Sapateiro, Maré, Nova Holanda, Major Rubens Vaz e Parque União instaladas na orla da Baía de Guanabara de frente ao aeroporto internacional.
}

[Digite texto] 
No contexto de transição, a ocorrência de um fato significativo: em 1979, o governo federal, numa tentativa de reaproximar-se das massas populares urbanas, abandona a política de remoção e propõe o Projeto Rio, um grande projeto de urbanização dos núcleos que compunham a Favela da Maré, no qual se previa a erradicação das palafitas. Esse projeto integrava o Programa de Erradicação da Sub-habitação (PROMORAR), um dos programas instituídos pelo $\mathrm{BNH}$, na segunda metade da década de 1970, já no contexto de abandono da política de remoção. O surgimento de tal programa reflete a mudança de orientação das instituições multilaterais - como o Banco Mundial e o BID -, por força dos resultados da Primeira Conferência das Nações Unidas sobre Habitação, realizada em Vancouver, em 1976 (Gonçalves 2006).

$\mathrm{O}$ instrumento jurídico buscado para "minimizar as dificuldades jurídicas e os diferentes custos que a individualização dos lotes provocaria, tornando-se mais simples a concessão de títulos de propriedade definitivos", foi o do condomínio horizontal, uma solução inspirada na Lei 4.591 de 1964, que era voltada ao padrão de habitação urbana das classes médias. Assim, cada quadra equivaleria a um condomínio, no qual os favelados se manteriam titulares de suas respectivas unidades, porém, quanto à propriedade do solo, diferentemente dos loteamentos, eles deteriam uma fração ideal (ou quota parte) sobre ele, assim como ocorre com relação aos titulares de apartamentos em edificações. A experiência do Projeto Rio serviu para demonstrar algumas das dificuldades da regularização fundiária, em favelas, dentre elas, a proteção extrema da propriedade privada, as exigências dos cartórios de registro imobiliário e a ausência de instrumentos jurídicos adequados (Gonçalves, 2006).

No contexto da atuação do governo federal na política de urbanização das favelas, o Projeto Rio foi gerado por uma combinação local de órgãos das três esferas do governo. O Projeto Rio era composto de um variado e complexo conjunto de ações setoriais e programas específicos localizados numa área urbana do Estado do Rio de Janeiro. Tratava-se, na verdade, de uma política do governo federal, de vasto alcance que passou a ser articulada com o governo estadual e o governo municipal do Rio de Janeiro. A área de abrangência do projeto era uma faixa costeira da Baía de Guanabara próxima 
do aeroporto internacional e correspondia a um conjunto de favelas localizadas numa área alagadiça e insalubre.

Segundo referências do governo, o Projeto Rio foi pioneiramente 0 projeto que viabilizaria de fato a urbanização das favelas a partir do planejamento participativo com base nas reivindicações da população de baixa renda organizada em grupos representativos e da sua suposta participação na formulação das políticas urbanas. O projeto previa, além da melhoria das condições de moradia, a regularização fundiária das favelas, paradoxalmente às áreas até então excluídas das políticas urbanas cujas leis e normas buscavam a remoção desses aglomerados urbanos e não as contemplavam sob possíveis condições de regularização.

De modo geral, programas previam cooperação técnica e financeira aos municípios para execução de projetos de infraestrutura urbana, e o FAS-Fundo de Apoio ao Desenvolvimento Social representava um instrumento da política social do governo, com a finalidade de contribuir para a redução das desigualdades intra e inter-regionais. Os recursos, obtidos por financiamentos, portanto reembolsáveis, destinavam-se a atender as cidades de pequeno porte (até 50 mil habitantes) e que estivessem a descoberto por parte de outros programas oficiais, na maioria das vezes apresentando-se como centros com maior carência. Os programas e projetos especiais a que destinavam os recursos do FAS abrangiam os setores de Saúde, Previdência Social, Educação e Cultura, Trabalho, Interior e Justiça, envolvendo, portanto, os ministérios correspondentes a cada um desses setores, para os quais existiam prioridades estabelecidas. ${ }^{67}$

Em busca de maior equilíbrio entre as microrregiões da Região Sudeste, a SERSE desenvolvia programas de desenvolvimento regional direcionado para as microrregiões de menor desenvolvimento como o norte do Espírito Santo com o PRODESP- Programa de Desenvolvimento Microrregional do

\footnotetext{
${ }^{67}$ No caso do Ministério do Interior, essas prioridades eram: equipamentos urbanos não financiados por outras fontes, tais como mercados, lavanderias, sanitários públicos e equipamentos para coleta e destinação final do lixo, serviços de drenagem pluvial e implantação de guias de meio-fios em núcleos com até 50 mil habitantes, serviços de esgoto sanitário e sistema de abastecimento de água simplificado para áreas rurais e núcleos com até 10 mil habitantes.
}

[Digite texto] 
Norte do Espírito Santo ${ }^{68}$ e o Vale do Jequitinhonha com o PRODEVALEPrograma de Desenvolvimento Regional Integrado do Nordeste de Minas Gerais. ${ }^{69}$ Esta era considerada uma região geradora dos maiores fluxos migratórios no pais, decorrentes da falta de "uniformidade" territorial de seu desenvolvimento econômico e das áreas de "bolsões de pobreza", ${ }^{70}$ em comparação aos importantes centros urbanos que atuavam como pólos de atração, com a migração rural-urbana gerando fortes impactos na economia regional com a redução das atividades agrícolas e os problemas urbanos de ordem social como o crescimento desordenado das favelas nas metrópoles. Tal quadro, segundo o discurso do governo, justificava a suposta ação contínua de investimentos em obras de infraestrutura, saneamento básico, habitação, escolas, hospitais entre outros.

O Programa Nacional de Migrações Internas no Sudeste funcionava a partir de convênios entre a SERSE e entidades dos governos estaduais, que se responsabilizavam pela execução dos subprogramas SIMI - Sistema de Informações sobre Migrações Internas ${ }^{71}$, SAMI - Serviço de Apoio aos Migrantes $^{72}$ e Pesquisa ${ }^{73}$. A fim de levantar, recuperar dados e disseminar informações sobre a Região Sudeste, o MINTER a partir da SERSE mantinha

\footnotetext{
6868 O PRODESP foi implantado em 1981 a partir do convênio celebrado entre a SERSE e o Governo do Estado do Espírito Santo. Seu objetivo era promover a interiorização do desenvolvimento e melhorar as condições de vida da população de sua área de abrangência composta por 14 municípios.

${ }^{69}$ O PRODEVALE- foi criado em 1979 e contava com os recursos do governo do Estado de Minas Gerais e em 1980 o MINTER submeteu à Secretaria de Planejamento da Presidência da República proposta de destinação de recursos financeiros provenientes do Fundo Nacional de Desenvolvimento e a partir de 1981, o PRODEVALE passou a contar com recursos federais aplicados a fundo perdido nos setores de saúde e saneamento, educação, apoio à produção, trabalho, ação social, transportes, eletrificação e barragem. O programa e abrangia o Vale do Jequitinhonha, região extremamente desfavorecida do nordeste de Minas Gerais no trecho compreendido entre os cursos alto e médio dos rios Jequitinhonha e Mucuri e o alto curso do rio São Matheus.

70 Os chamados "bolsões de pobreza" correspondiam às regiões do Vale do Ribeira e o Pontal de Paranapanema em São Paulo, o Vale do Jequitinhonha em Minas Gerais, o Norte Fluminense no Rio de Janeiro e o norte do Espírito Santo.

${ }^{71}$ O SIMI correspondia à atividade sistêmica de levantamentos de dados sobre o movimento migratório no território, a partir de unidade de coleta instalada nos municípios.

72 O SAMI tinha caráter assistencial e visava atenuar as constantes dificuldades com que se defrontava a população migrante em seu deslocamento no espaço. A operação SAMI desenvolveu-se a partir de uma rede de unidade de atendimento colocadas em pontos de passagem e desembarque de migrantes.

${ }^{73}$ O Subprograma de Pesquisa está a cargo de duas unidades confederadas do Sudeste: a FAPERJ no Rio de Janeiro que focalizava o quadro migratório estadual e suas características e a SEADE- Fundação Sistema Estadual de Análise de Dados em São Paulo que realizou a pesquisa "Recuperação do PROALCOOL no comportamento migratório do Estado de São Paulo: o caso Ribeirão Preto"
}

[Digite texto] 
uma estrutura de subsistemas que contribuíam para a coordenação, planejamento e controle.

A SERSE era dirigida por um Secretário, que contava, para o exercício de atribuições específicas, com a colaboração de uma Assessoria Jurídica e uma Assessoria de Comunicação Social. Para o desempenho das tarefas que Ihe eram atribuídas, a SERSE possuía uma subsecretaria de planejamento, composta de quatro coordenadorias: de Programas Especiais, de Desenvolvimento Urbano, de Planejamento Regional e de Informática. Para execução de atividades especiais ligadas ao atendimento de calamidades públicas ocorridas na área, a SERSE contava com uma Coordenadoria Regional de Defesa Civil. Secundando as atividades exercidas pela Subsecretaria de Planejamento - SPLAN dispunha a SERSE da seguinte estrutura de apoio: Serviço Administrativo, Serviço de Pessoal, além de uma Seção de Apoio Administrativo. Finalmente, compondo ainda a estrutura da Secretaria havia uma Divisão de Segurança e Informações e o Núcleo da Secretaria Especial do Meio Ambiente - SEMA.

No contexto de integração das esferas do governo, foi criado pelo Decreto No 14 de 1975 o organismo responsável pelo desenvolvimento regional da Região Metropolitana do Rio de Janeiro denominado Fundrem Fundação de Desenvolvimento da Região Metropolitana do Rio de Janeiro vinculado à Secretaria de Planejamento e Coordenação Geral da Governadoria do Estado do Rio de Janeiro; seguia as diretrizes do II PND - Plano Nacional de Desenvolvimento, que propunha amenizar os desníveis regionais de desenvolvimento industrial compatibilizando os movimentos de descentralização. O governo federal canalizou recursos para o novo Estado do Rio de Janeiro a fim de concretizar a Fusão utilizando-se da fundação como o primeiro órgão de planejamento da região, responsável em amenizar os conflitos gerados pela Fusão. Cabia a Fundrem gerir o Fundo Contábil da Região Metropolitana e politicamente decidir pelo financiamento dos programas e projetos regionais.

Nos primeiros anos o volume de recursos consubstanciou-se em obras de infraestrutura e equipamentos urbanos, embora a maior parte fosse concentrada no município do Rio de Janeiro. A Fundrem, considerada uma agência de poder, foi constituída sob uma legislação flexível para agilizar as 
decisões do Conselho Consultivo ${ }^{74}$ e ligada à Secretaria de Planejamento e do governo do Estado. A referida fundação foi constituída com autonomia, integrava a administração indireta do Estado e tinha orçamento próprio, a fim de se tornar ao máximo ágil na realização dos programas da região, assim burlando, pretensamente, os meios burocráticos e as políticas clientelistas tão típicas. Sua principal função era alocar os recursos do fundo para as agências de operação do Estado ou para acordo de prioridades do governo local pela administração federal e estadual.

A atuação da Fundrem assumia um papel pioneiro no planejamento físico-territorial-regional a partir dos programas de estudos para a elaboração de banco de dados e informações cartográficas, e no suporte técnico para a elaboração dos planos diretores dos municípios, que assegurassem o controle da ocupação do solo e das edificações, assim como estudos direcionados à distribuição das áreas de atividades industriais na Região Metropolitana, a fim de ordenar o espaço em busca de maior equilíbrio espacial com base no projeto de macrozoneamento. $\mathrm{O}$ projeto do macrozoneamento elaborado definia padrões de ordenamento territorial da região metropolitana a serem seguidos pelos órgãos estaduais e municipais, visando maior controle da expansão urbana.

No entanto, os municípios do Rio de Janeiro e de Niterói não compactuaram com as propostas da fundação quanto a um macrozoneamento para ordenamento do uso do solo de seus territórios, por posicionamento de oposição política ao governo federal e resistência política às tradicionais interferências do governo federal. Uma grande maioria dos demais municípios fixou um convênio com a Fundrem para elaborar seus planos diretores; o governo local resistia às influências do governo federal. Valendo-se dos resultados de sua pesquisa, Gondim, (1986: 151-152) sintetiza:

In addition, Fundrem's Power was limited by municipal autonomy. Despite the economic and political weakness of local governments in Brazil, the

\footnotetext{
${ }^{74} \mathrm{O}$ Conselho Consultivo era formado por representantes das 14 prefeituras da Região, e funcionava como foro de debates onde funcionavam um foro de debates dos problemas sócio-econômicos de âmbito comum e de onde surgiam as indicações que se somariam a outras dos órgãos setoriais e contribuíam na formulação global da política de desenvolvimento regional, cujo órgão decisório máximo era o Conselho Deliberativo.
}

[Digite texto] 
administrations of large cities such as Rio de Janeiro and Niterói have resisted state and federal interference, while even small municipalities have kept land use control as one of their few prerogatives. ${ }^{75}$

As portarias No 46/77 e No 12/78 editadas pelo Conselho Deliberativo da Fundrem sobre o desenvolvimento urbano dispunham que normas estaduais e municipais referentes ao uso e ocupação do solo deveriam seguir os padrões oferecidos pela fundação na formulação de seus planos diretores, códigos de zoneamento e normas de parcelamento; e dispunha a segunda que a fundação fiscalizaria a execução das decisões do Conselho Deliberativo sobre uso e ocupação do solo metropolitano. A atuação da Fundrem foi buscar maior integração físico-territorial-regional das políticas de desenvolvimento urbano e regional entre os níveis federal, estadual e municipal de governo, presentes numa suposta realidade regional.

Embora o principal objetivo da Fundrem fosse promover maior articulação entre os municípios constituintes da Região Metropolitana do Rio de Janeiro, as políticas direcionadas para o ordenamento do território do município do Rio de Janeiro estavam descontextualizadas das propostas da fundação e muito mais voltadas para seu próprio município em detrimento de sua respectiva região de influência.

A desarticulação das políticas públicas se expressava nos planos desenvolvidos nessa época, como o PUB-RIO, de extrema importância para o planejamento local, mas que apenas contemplou os limites políticoadministrativos do território do município do Rio de Janeiro, assim como o PITMETRO que consumiu uma quantia muito elevada de recursos na época e inicialmente favoreceu a área central mais nobre da cidade. Inclusive a assistência técnica da Fundrem esteve muito mais voltada a outros municípios pela suposta auto-suficiência humana e de recursos técnicos do Rio de Janeiro, como Godim (1986: 144) expressou:

\footnotetext{
75 - Acrescentando, Poder da FUNDREM estava limitado pela autonomia municipal. Apesar da fragilidade econômica e política dos governos locais no Brasil, as administrações das grandes cidades como Rio de Janeiro e Niterói tem resistido às interferências dos governos do estado e federal, enquanto mesmo pequenos municípios tomam o controle do uso da terra como uma de suas poucas prerrogativas.
}

[Digite texto] 
(FUNDREM did not offer technical assistance to Rio de Janeiro, whose human and technical resources were considered sufficient.) ${ }^{76}$

A Fundrem e o BNH patrocinaram ao longo da década de 70 determinadas instituições que organizaram seminários e estudos liderados por representantes da sociedade civil responsáveis pelas políticas de crescimento do Rio de Janeiro. Os setores imobiliário, técnico e financeiro de habitação intermediados por representantes de universidades e outras organizações representativas da sociedade reuniram-se em $1979^{77}$ a fim de discutirem o crescimento do Grande Rio à luz de um enfoque de planejamento em dois níveis: metropolitano e municipal, e outro de política de uso do solo e de transportes.

Paradoxalmente, o encontro buscou discutir os meios para construir moradias destinadas à população de baixa renda e garantir a participação dos setores interessados na formulação da política urbana. O encontro buscou dar maiores esclarecimentos à sociedade quanto aos desafios lançados aos Estados e municípios no processo de planejamento metropolitano e municipal respectivamente, à importância dos instrumentos de ordenação do uso do solo e à política de transportes em relação à realidade metropolitana do Rio de Janeiro. Uma das sínteses do encontro reconhecia o tamanho desafio da questão metropolitana para a administração do governo e propunha um planejamento físico-territorial valendo-se da institucionalização da Região Metropolitana do Rio de Janeiro sob o mesmo ato decisório do governo da Fusão em 1974.

Para a Fundrem, a questão metropolitana lançaria uma nova forma de planejamento regional a cargo do Estado, como previsto na própria Constituição de 1967, num suposto processo de mutação permanente opondose a toda forma de planejamento até então praticada. $O$ planejamento

\footnotetext{
76 - FUNDREM não ofereceu assistência técnica ao Rio de Janeiro, cujos recursos humanos e técnicos eram considerados suficientes.

${ }^{77}$ O Seminário O crescimento da Região Metropolitana do Rio de Janeiro foi realizado em 1979 sob o patrocínio da Associação dos Dirigentes de Empresas do Mercado Imobiliário - ADEMI, e da Associação Regional das Empresas de Crédito Imobiliário e Poupança - ARECIP, contando com o apoio técnico e financeiro do Banco Nacional da Habitação - BNH e representantes da Fundrem, do IBAM e da Secretaria Municipal de Planejamento do Rio de Janeiro e com a Coordenação Executiva da responsabilidade do Núcleo de Estudos Sociais para Habitação e Urbanismo - NEURB, da Pontifícia Universidade Católica do Rio de Janeiro - PUC/RJ.
}

[Digite texto] 
metropolitano seria o próprio reconhecimento dos problemas econômicos e sociais decorrentes da industrialização e da acelerada urbanização dos grandes centros urbanos e que transcendia os limites político-administrativos. O planejamento metropolitano deveria ser concebido como uma prática dinâmica. O presidente da Fundrem, Fernando Talma Sampaio (1979,p 11) sintetizou o posicionamento da instituição quanto à questão urbana nos anais do seminário

Portanto, a questão urbana não está delimitada geograficamente, mas se insere no quadro maior da própria realidade econômica e social do país; e também não está delimitada no tempo, estaticamente, devendo ser apreendida em sua dimensão histórica, como um processo em permanente mutação. $E$ apenas levando-se em conta esses dois níveis, naturalmente, ela poderia ser integralmente equacionada.

Segundo o posicionamento da Fundrem, a Região Metropolitana do Rio de Janeiro deveria ocupar lugar de destaque na própria formulação global da política estadual de desenvolvimento. E como o Estado e municípios dispunham de seus órgãos de execução, o planejamento metropolitano usaria essa infraestrutura na execução dos programas de âmbito regional, evitando a duplicação e a concorrência de esforços, sobretudo o desperdício injustificável de recursos com a criação de mais uma instância oficial para execução de obras públicas. As normas do planejamento estadual prevaleceriam para o planejamento metropolitano, que deveria ser realista e pragmático, ou seja: nenhum programa seria lançado sem definição prévia da fonte de recursos, com o que a arte de planejar teve de obedecer a rigorosos critérios de eleição de prioridades para aplicação de recursos escassos.

Segundo a Fundrem, os instrumentos institucionais de formulação do planejamento metropolitano integrar-se iam ao planejamento estadual de modo sistemático, em que o Conselho Consultivo, formado por representantes das 14 municipalidades da região, funcionaria como foro de debates onde seriam permanentemente levantados problemas sócio-econômicos de âmbito comum e de onde surgiriam as indicações que, somadas a outras oriundas dos órgãos setoriais do Estado, alimentariam o processo de formulação global da política 
de desenvolvimento regional, cujo órgão decisório máximo seria o Conselho Deliberativo.

A Fundrem constituiu o órgão de apoio técnico a esses dois colegiados, cabendo à instituição gerir o Fundo Contábil da Região Metropolitana, através do qual são canalizados os recursos para o financiamento dos programas e projetos regionais. O objetivo principal da Fundrem seria atuar como um centro de estudos, levantamentos e fornecimento de informações sobre a realidade metropolitana. De modo a dar continuidade às políticas de investimentos dos governos antecessores, grande parte dos recursos foi alocada em obras de transporte coletivo como o Metrô, saneamento básico, saúde, privilegiando a área central da região em detrimento das obras de expansão e melhoria da rede ferroviária que atenderia a um número maior de municípios e beneficiaria um número maior de pessoas residentes nos municípios constituintes da região, assim perpetuando os graves problemas urbanos.

A Fundrem como órgão do sistema de planejamento metropolitano considerou a Fusão entre os dois Estados como sinônimo de remoção do obstáculo institucional para a consecução de um planejamento para a Região Metropolitana do Rio de Janeiro que permitisse um crescimento mais ordenado, a partir de uma maior integração das políticas de desenvolvimento dos vários níveis de governo: federal, estadual e municipal, presentes na realidade regional. A fundação reconhecia que o ordenamento territorial proposto para a Região Metropolitana do Rio de Janeiro impunha um consenso entre os interesses dos grupos sociais, em destaque os empresários do setor imobiliário como uma das forças econômicas e politicamente mais expressiva, de cuja participação nenhum projeto de desenvolvimento poderia prescindir. A participação das diferentes representações dos grupos sociais deveria transcender o âmbito de seus interesses, no que foi denominada de consciência social no enfrentamento das questões da urbanização ou do desenvolvimento nacional.

No entanto, segundo o Estudo 1- Desenvolvimento Institucional e a Gestão do Espaço Metropolitano do Rio de Janeiro, elaborado nos Estudos para integração de políticas públicas na Região Metropolitana do Rio de Janeiro pelo IplanRio em 1994, concluiu que a criação da Fundrem esteve ligada à fusão dos Estados da Guanabara e do Rio de Janeiro, num período de 
centralismo e enfraquecimento das autonomias política, administrativa e financeira dos governos municipais. Os resultados apresentados por essa entidade foram limitados, senão muito aquém dos propósitos invocados para a sua criação. De um lado, os municípios tinham poucos poderes nas instâncias decisórias e operativas então criadas, tendendo a alhearem-se de efetivos compromissos com ações. De outro, havia a inexistência de fontes de receita seguras para a manutenção das atividades das entidades metropolitanas, incluindo os governos federal e estadual e agências internacionais. De fato, essas entidades metropolitanas limitaram-se em grande parte, a ações de planejamento urbano. Muito pouco foi realizado em termos de gestão de serviços de interesse comum. No Rio de Janeiro, foram realizados, no final da década de 70; estudos e planos de âmbito metropolitano e municipal com alcance prático limitado. No que diz respeito à promoção econômica e social acentuou-se o modo centro-periférico com impactos negativos tanto na metrópole quanto na sua periferia imediata.

Após a Fusão, a cidade do Rio de Janeiro passou a ser a capital do Estado do Rio de Janeiro e o governo municipal de Marcos Tamoio viu a necessidade de elaborar um plano, o PUB-RIO - Plano Urbanístico Básico da Cidade do Rio de Janeiro ${ }^{78}$ a fim de fortalecer a posição da cidade como Pólo da Região Metropolitana. Diante da realidade metropolitana quanto à problemática de ocupação do solo, o plano, por mais uma vez, voltou-se para os aspectos urbanos e administrativos necessários para o governo descartando toda a área metropolitana da proposta diferenciada dos instrumentos de ação que permitiriam implantar o plano. O PUB-RIO propôs uma divisão do território municipal em seis Áreas de Planejamento considerando características físicas, sócio-econômicas e funcionais dos bairros.

A definição de traçados viários, padrões de uso de solo, e planos de massa ficaria a cargo dos PEU's- Projetos de Estruturação Urbana para o planejamento local que perduram como base do planejamento nas estruturas do governo municipal até os dias atuais. Os PEU's seriam elaborados pela

\footnotetext{
${ }^{78}$ O PUB RIO foi constituído pelo Decreto No 1269 de 1977 pela Prefeitura da Cidade do Rio de Janeiro sob caráter de permanente atualização consistiu num plano de expansão da cidade baseado no conceito de densidade dinâmica e adotava um sistema de soluções setorializadas. Subdividiu o território do município em seis APs - Áreas de Planejamento que abrangiam determinadas regiões administrativas
}

[Digite texto] 
Superintendência de Planejamento da Secretaria Municipal de Planejamento e aprovados por decretos após apreciação pela Comissão do Plano da Cidade.

Segundo o Decreto No 1269/77 que instituiu o PUB-RIO, as áreas sujeitas aos PEUs seriam áreas de centros e subcentros funcionais, existentes ou em potencial; áreas remanescentes à execução de obras civis de porte; áreas em processo de renovação ou remanejamento urbano; áreas constituídas por vazios urbanos e áreas de expansão periférica.

Mapa 3 - Áreas de Planejamento

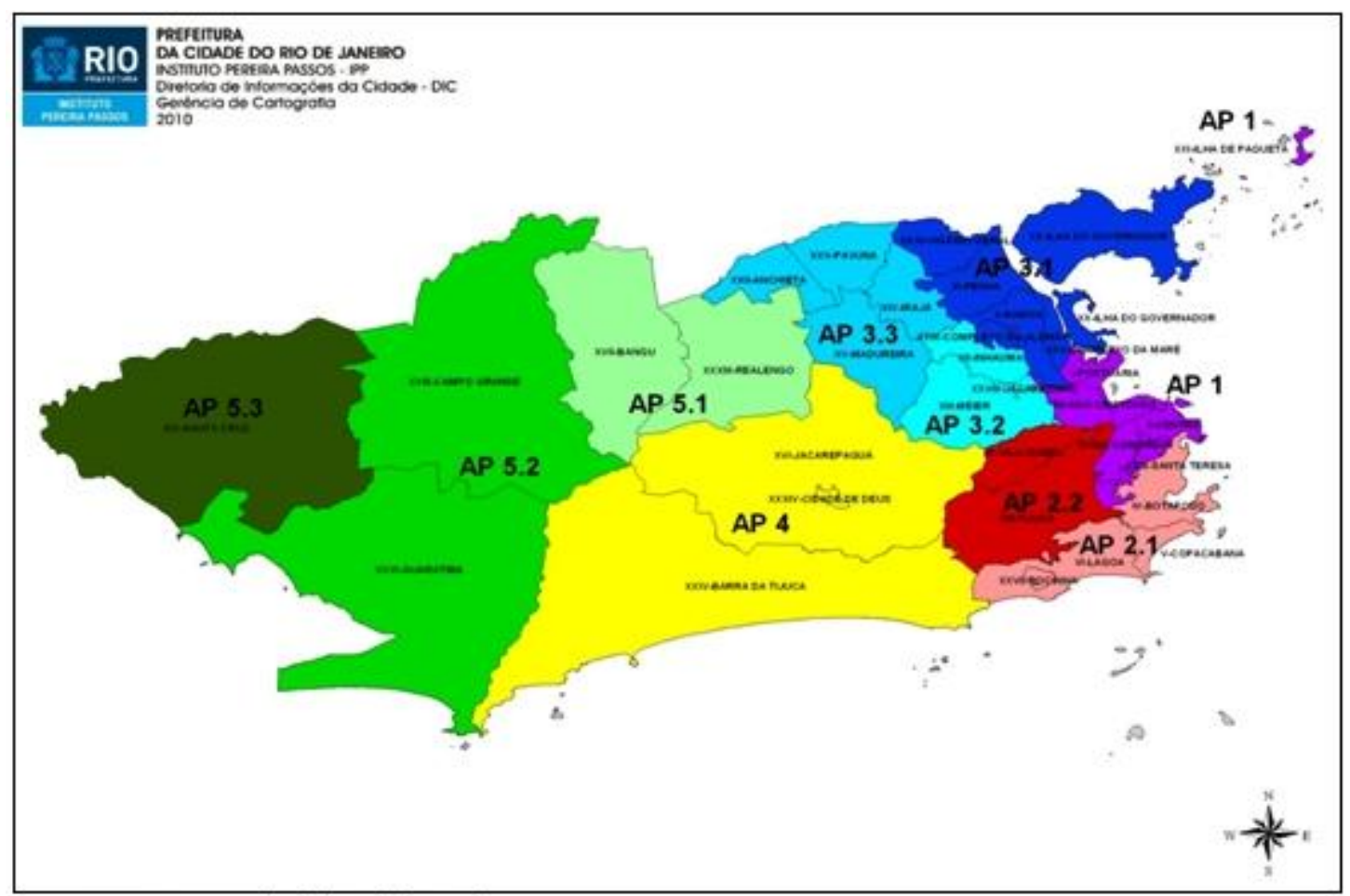

Fonte: wwwarmazemdedados rio ri.gov.br.

Embora o PUB-RIO reconheça a necessidade de uma maior articulação entre os três níveis do governo para viabilizar projetos setoriais inclusive citados diante da realidade metropolitana do Rio de Janeiro e fundamentais para 0 desenvolvimento urbano do município, o mesmo admite a impossibilidade de por em prática os projetos, pelas limitações impostas e explícitas nas competências do município e chamou a atenção aos demais níveis de governo para a consecução dos objetivos pretendidos, sobretudo na questão dos transportes, visando maior acessibilidade interna e externa à 
Região Metropolitana do Rio de Janeiro; e apontou ações no planejamento a serem consideradas no processo de ocupação do território municipal como: preservação ambiental, preservação paisagística, remanejamento progressivo, reestruturação urbana, adensamento puntiforme e ocupação progressiva em cada Área de Planejamento do município.

As diretrizes e prioridades estabelecidas pelo PUB-RIO vêm sofrendo detalhamento e atualização, ao passo das necessidades de adaptação do território municipal às exigências infraestruturais que se apresentam por meio de planos setoriais que alteram a legislação de desenvolvimento urbano, como no caso da implantação do Metrô e sua expansão, do código de obras e de projetos urbanos que alteram as definições para adequar o espaço urbano aos novos usos e apropriações; ou, em outras palavras, para atender aos interesses das classes mais influentes nas decisões políticas e econômicas.

Ainda no contexto das decisões do governo federal sobre as regras que flexibilizassem o direito ao solo urbano, o Presidente João Figueiredo sancionou a Lei 6766 de 1979 que dispôs sobre o parcelamento do solo urbano adequando-o às peculiaridades regionais e locais. Segundo o disposto na lei, o parcelamento do solo urbano poderia ser feito mediante loteamento ou desmembramento destinados à edificação. O Art. $3^{\circ}$ dispôs que somente seria admitido o parcelamento do solo para fins urbanos em zonas urbanas, de expansão urbana ou de urbanização específica, assim, definidas pelo plano diretor ou aprovadas por lei municipal. Por sua vez, contraditoriamente à realidade do espaço constituído em questão, o Parágrafo Único dispôs que não seria permitido o parcelamento do solo em terrenos alagadiços e sujeitos às inundações, em terrenos que tenham sido aterrados com material nocivo à saúde pública, em terrenos com declividade igual ou superior a $30 \%$, em terrenos onde as condições geológicas não aconselham a edificação, em áreas de preservação ecológica ou naquelas onde a poluição impeça condições sanitárias suportáveis, e aponta no $\S 1^{\circ}$ do Art. IV que a legislação municipal definirá para cada zona em que se divida o território do município, os usos permitidos e os índices urbanísticos de parcelamento e ocupação do solo, que incluiriam obrigatoriamente as áreas mínimas e máximas de lotes e os coeficientes máximos de aproveitamento. 
Esta lei, considerada importante referência jurídica às mudanças políticas a partir do fim dos anos 70 , sedimentou a extrema importância do controle do loteamento do solo urbano pelas autoridades competentes como exigia que todas as cidades com mais de cinquenta mil habitantes dispusessem de uma lei regulamentando a ocupação do solo urbano, alguns parâmetros mínimos de loteamento relacionados às condições mínimas de infraestrutura, assim como perpetuava o não reconhecimento legal dos terrenos desvalorizados sob o ponto de vista do setor imobiliário susceptíveis à ocupação da população de baixa renda e flexibilizava essa regras quando se tratasse das denominadas ZEIS - Zonas Especiais de Interesse Social reconhecidas nos nossos dias como um instrumento indispensável para toda a ação que visa regularizar o complexo aspecto fundiário das favelas.

Ao processo de abertura econômica iniciado com o governo do generalpresidente Ernesto Geisel em 1974 e acelerado no governo de seu sucessor, o general Figueiredo (1979 a 1985), que promulgou uma anistia política e restabeleceu a liberdade de partidos e finalmente convocou eleições diretas para os governos dos Estados, atribuímos muitas mudanças ocorridas no direcionamento das políticas de ordenamento territorial no contexto de elevada inflação, desestabilização monetária e déficit nas contas públicas. Teve importância também a eleição de Leonel Brizola, para governo do Estado, que nos seus dois mandatos reafirmou a política urbana clientelista, perpetuando a especulação ao direito ao solo urbano e as relações ilegais pela não realização da regularização fundiária ${ }^{79}$.

Ressaltamos que a partir da década de 1970, a política urbana passou a ordenar e a legalizar as favelas ao invés de tentar erradicá-las do contexto urbano. No entanto, as tentativas de regularização fundiária se resumiam na expropriação e na usucapião que por sua vez eram incapazes de responder aos déficits jurídicos no processo de ocupação do solo. Por outro lado, a

\footnotetext{
79 Em contraposição à política de remoção/assentamento da população favelada que não surtia os resultados esperados e às reivindicações das associações de interesse dos favelados pelo reconhecimento legal de seus imóveis, as políticas públicas direcionadas a essas aglomerações urbanas buscou títulos de propriedade que de fato resultou numa sensível melhora do padrão de construção das moradias das favelas que passaram gradativamente de material reciclado para alvenaria. As tentativas de regularização fundiária iniciou-se no governo Brizola em 1983 com a criação do programa "Cada família, um lote" que foi extinto por Moreira Franco em 1987.
}

[Digite texto] 
expropriação das terras onde se localizavam as favelas estava fora da competência do poder público pelo não reconhecimento da legalidade de sua existência. De outro, ainda, o instrumento de usucapião era inaplicável em função dos procedimentos administrativos e judiciários extremamente complexos. Do ponto de vista jurídico, a questão das favelas necessitava de uma nova legislação capaz de garantir a sua integração social e espacial ao restante da cidade de modo que permitisse de fato uma ação do poder público sobre esses espaços.

No caso do Rio de Janeiro, algumas mudanças ocorreram nos órgãos do governo local de modo a adquirirem um viés social direcionados à assistência social das camadas desfavorecidas. No caso específico das favelas, o ideário que passou a predominar nas ações públicas visava à reabilitação do conjunto de favelas da cidade em contraposição às práticas clientelistas que sempre estiveram presentes ao longo dos anos na estruturação da cidade. Muitos projetos de regularização fundiária e de instalação de serviços públicos nestes espaços despontavam nos governos locais, mas sem um apoio jurídico, político, institucional e social relacionados a esses espaços conduziam à descontinuidades dessas políticas e à perpetuação das práticas clientelistas e aos governos populistas que estabeleciam uma estreita ligação entre o voto e 0 acesso de recursos e serviços públicos do governo. As tentativas políticas de regularização fundiária desses espaços subsidiadas pelo governo federal nunca foram bem sucedidas no caso do Rio de Janeiro pelas incompatibilidades e duras oposições entre governo do Estado e o governo federal.

Extinto o CNPU, foi substituído pelo CNDU - Conselho Nacional de Desenvolvimento Urbano pelo Decreto Lei No 83355 de $1979^{80}$, no último governo militar, que tinha por finalidades: propor diretrizes, estratégias, prioridades e instrumentos da Política Nacional de Desenvolvimento Urbano;

\footnotetext{
${ }^{80}$ O CNDU era integrado pelo Ministro de Estado do Interior que o presidia; pelos Secretários-Gerais de Planejamento da Presidência da República; e dos Ministérios da Fazenda, do Interior, dos Transportes, da Indústria e do Comércio; pelos Presidentes do BNH- Banco Nacional de Habitação e da EBTUEmpresa Brasileira dos Transportes Urbanos; e por três membros nomeados pelo Presidente da República, com mandato de dois anos, prorrogável por igual período. Já nesta composição, pretensamente buscava uma melhor integração das ações do governo no campo do desenvolvimento urbano, como conselho de cunho interministerial, tem como presidente o próprio Ministro do Interior.
}

[Digite texto] 
propor programas anuais e plurianuais de investimentos urbanos e a programação de apoio financeiro oficial ao desenvolvimento urbano; propor a programação anual do Fundo Nacional de Apoio ao Desenvolvimento Urbano e de outros recursos destinados a programas de desenvolvimento urbano, a serem despendidos diretamente pela União e transferidos aos Estados, Distrito Federal e Municípios, para transporte urbano e administração metropolitana e municipal; propor os instrumentos fiscais, financeiros e creditícios; propor a legislação básica e complementar; expedir normas e diretrizes. ${ }^{81}$

Diante da insustentável situação urbana do Brasil e especificamente do Rio de Janeiro, em que a especulação imobiliária tomou proporções desmesuráveis ao ponto de suscitar um novo debate político, visando modificar a legislação vigente em vista de garantir um controle público mais severo sobre o desenvolvimento urbano, o CNDU formulou no início dos anos de 1980 o anteprojeto de lei No 775 de 1983 que aumentava o poder público de intervenção sobre os instrumentos de desenvolvimento urbano a fim de assegurar a utilização da propriedade segundo suas funções sociais ${ }^{82}$, o que gerou inúmeras controvérsias entre diferentes setores da sociedade.

Envolto pela crise econômica, déficit público, recessão, desemprego, o processo de redemocratização do país não só significou o fim do período da ditadura militar, mas de mudanças na estrutura do governo como resposta a algumas reivindicações de setores da sociedade. As mudanças estiveram limitadas pela própria Constituição Federal de 1967 instituída no período autoritário. Novas reformas ministeriais foram acompanhadas de mudanças administrativas visando se adequarem aos novos parâmetros do governo,

\footnotetext{
81 Para a coordenação e acompanhamento da execução da política nacional de desenvolvimento urbano, o Conselho tinha como apoio técnico e administrativo a Subsecretaria de Desenvolvimento Urbano ligada a Secretaria-Geral do Ministério do Interior. A Subsecretaria estava estruturada em quatro Coordenadorias: Coordenadoria de Política e Legislação Urbana; Coordenadoria de Planejamento Setorial; Coordenadoria de Regiões Metropolitanas; Coordenadoria de Cidades de Médio e Pequeno Porte.

${ }^{82}$ A Lei 4132 de 1962 sancionada pelo presidente João Goulart definiu os casos de desapropriação por interesse social para promover a justa distribuição da propriedade ou condicionar o seu uso ao bem estar social na forma do art. 147 da Constituição Federal que dispôs o uso da propriedade será condicionado ao bem estar social. A lei poderá, com observância do disposto no art.141, $\S 16$ (É garantido o direito de propriedade, salvo o caso de desapropriação por necessidade ou utilidade pública, ou por interesse social mediante prévia e justa indenização em dinheiro. Em caso de perigo iminente, como guerra ou comoção intestina, as autoridades competentes poderão usar da propriedade particular, se assim o exigir o bem público, ficando, todavia, assegurado o direito a indenização ulterior), promover a justa distribuição da propriedade, com igual oportunidade para todos.
}

[Digite texto] 
impostos pelos interesses de setores da sociedade na tentativa de debelar uma crise política e econômica que atingia o país.

Após o diagnóstico do despreparo jurídico, institucional e administrativo do gerir a Região Metropolitana do Rio de Janeiro na perspectiva do planejamento do desenvolvimento territorial integrado a partir da presença intervencionista do governo, constata-se nos anos 80 o esgotamento da estratégia desenvolvimentista que já se anunciava nos anos $70 \mathrm{com}$ as crises mundiais, em função do quadro recessivo de desestabilização financeira e monetária que afetou todo o sistema de planejamento em todos os níveis de governo e levou à regressão da política regional.

Após alguns anos de governos populistas, na sua grande maioria indicados pelos governadores do Estado, as eleições diretas para prefeito em 1985 simbolizou mudanças administrativas direcionadas para descentralização das atividades do poder público a partir da criação de novas agências municipais e novas secretarias, assim como para promover a participação da população nas decisões governamentais foram criados os Conselhos GovernoComunidade, demonstrando uma mudança no cenário político.

As mudanças no quadro político pouco refletiram nas leis urbanísticas. O prefeito sancionou o decreto No 7138 em 1987, que dispõe que a legislação edilícia do Rio de Janeiro deveria ser um fator de democratização do espaço urbano, igualando os direitos dos cidadãos às regras mínimas de higiene e segurança sem distinção de classe social. Antecedendo ao primeiro plano diretor da cidade, o referido decreto buscou normatizar construções e não contemplou a realidade do crescimento das favelas e os impactos ambientais na cidade. A própria omissão do decreto reforça os embates para inserir esses espaços ao restante da cidade e a total falência das tentativas de regularização fundiária das favelas dos governos anteriores.

$\mathrm{Na}$ crise das finanças públicas do município do Rio de Janeiro, o prefeito na época Saturnino Braga (1986-1988), apontava para uma reforma e a urgente necessidade de aumentar a arrecadação e reduzir os gastos públicos. No entanto, em vista de atender aos interesses eleitoreiros do partido PDT, adotou medidas que sobrecarregaram os gastos da prefeitura a ponto de inviabilizar sua administração e em 1988 ser declarada falida pelo prefeito. 
Segundo Medeiros Júnior (2009:2), a cidade do Rio de Janeiro contou até o final da década de 80, no Governo Saturnino Braga, com uma secretaria de planejamento cuja estrutura possuía capilaridade para absorver informações sobre os mais variados projetos e viabilizá-los no nível orçamentário, após submetê-los à discussões em conselhos governo-comunidade vinculados à secretaria de governo, nos quais associações de classe e comunidades os debatiam e selecionavam. Aquela estrutura ruiu com o retorno de Marcello Alencar (1989-1993) em seu segundo governo municipal, e nunca mais foi restabelecida.

A Região Metropolitana do Rio de Janeiro apresenta características que dificultam significativamente as tentativas de gestão regional. De um lado, existe uma forte fragmentação social entre o núcleo metropolitano e o seu entorno regional, caracterizada principalmente por uma frágil identidade cultural, por trajetórias históricas distintas e por uma organização produtiva e social diferenciada. De outro, há uma acentuada desarticulação entre as forças políticas atuantes no espaço metropolitano, levantando obstáculos à integração de políticas que adotem soluções comuns e também ao surgimento de um pacto-territorial que imprima um efetivo processo de regionalização à área. 


\subsection{Capítulo 5 - As ameaças ao planejamento do desenvolvimento territorial:entre a ação planejada e as intervenções imediatistas}

Faz-se necessário retomar e avaliar as políticas de ordenamento territorial urbano na metrópole do Rio de Janeiro no contexto das mudanças ocorridas após a Constituição Federal de 1988, com base no processo de redemocratização e descentralização de recursos e atributos pelos níveis de governo. Estados e municípios assumiriam um papel relevante no ordenamento territorial urbano sob os novos paradigmas da economia de mercado e de mudanças no planejamento governamental.

Após o período de crise nos anos de 1980 e o esgotamento da estratégia desenvolvimentista do governo central em comandar o ordenamento territorial em nível nacional em vista do crescimento econômico, o sistema de planejamento integrado e as políticas de ordenamento territorial foram abandonadas, com sensível agravamento das condições sociais e de infraestrutura urbana, principalmente nas grandes metrópoles.

O elevado déficit público, a desaceleração da taxa de crescimento da economia, a perda da capacidade fiscal, a queda da carga tributária e o descontrole das medidas predatórias de isenções fiscais concedidas pelos Estados e municípios conduziram o governo central a abandonar toda a estratégia de desenvolvimento urbano e regional e a direcionar esforços no controle inflacionário e na estabilização monetária no país.

A crise fiscal e financeira do governo afetou por completo os sistemas de planejamento, seja o nacional, os estaduais ou setoriais em decorrência de fatores como a redução de recursos financeiros destinados à promoção de programas e projetos, a perda da capacidade de captação de financiamento externo, bem como de empréstimos multilaterais. Decisões quanto aos resultados de curto prazo passaram a predominar sobre decisões de médio e longo prazo no ordenamento territorial. As demandas internacionais apontavam para uma urgente estabilização monetária, um ajuste da dívida externa e um controle rígido fiscal interno além da melhoria dos índices sociais. 
As relações intergovernamentais foram abaladas pela dificuldade de sustentação dos programas de gastos fiscais e com o sensível agravamento dos setores de atividades econômicas e de serviços dependentes dos repasses do governo federal como saúde, habitação, saneamento, transporte e educação. Os governos municipais, principalmente os das capitais, se viram impotentes para dar continuidade às políticas de desenvolvimento. Planos e programas de ordenamento territorial foram abandonados tanto pela falta de recursos internos e externos como pela incapacidade do governo de promover reformas abrangentes e de frear a deterioração das condições gerais de financiamento concomitantes ao elevado déficit público, como pela elevada taxa de inflação e as tentativas de democratização e descentralização tributária no país.

Os recursos de financiamento dos projetos de desenvolvimento do país vindos das instituições financeiras mundiais tornaram-se escassos e envolvidos em exigências de uma urgente estabilização financeira e monetária do país, de descentralização das atribuições do governo federal, maior legitimidade das políticas públicas a partir da participação da sociedade nas decisões e controle do governo. Alguns projetos de desenvolvimento importantes para o país tiveram a redução de seus recursos devido à instabilidade econômica, às elevadas taxas inflacionárias e às deficiências do sistema de planejamento do governo brasileiro da época. As condições impostas pelo Banco Mundial ao Brasil para dar continuidade à política de financiamento dos projetos de desenvolvimento foram: transparência orçamentária, alívio à repressão financeira, programa de privatização, preços justos e a abertura comercial ao exterior, fatores que foram se estruturando e se legitimando nos anos seguintes, a partir de reformas e mudanças nas estruturas do governo.

A reforma tributária expressa na Constituição Federal de 1988 baseouse na descentralização dos recursos arrecadados pela União a partir de transferências fiscais aos Estados e municípios, com base na alteração das alíquotas aplicadas aos impostos de repartição obrigatória constitucionalmente disposta, bem como à autonomia de gastos dos governos locais sobre os recursos recebidos. A reforma tributária não contemplou mudanças da autonomia para Estados e municípios tributarem, reforçando a dependência dessas instâncias das transferências fiscais da União e a ausência de vínculo e 
compromisso entre que instância arrecada e que instância gasta, proporcionando verdadeiro desequilíbrio fiscal por parte dos governos subnacionais, principalmente dos municípios das capitais de regiões metropolitanas, que se deparam com elevados gastos para manterem bens e serviços sobre seu território.

Em destaque, a Constituição Federal de 1988 atribuiu à União a competência de elaborar e executar planos nacionais e regionais de ordenação do território e de desenvolvimento econômico e social (art.21: IX); aos Estados a competência de instituir regiões metropolitanas, aglomerações urbanas e microrregiões constituídas por agrupamentos de municípios limítrofes, para integrar a organização, o planejamento e a execução de funções públicas de interesse comum (art. $25 \S 3^{\circ}$ ) e aos municípios, legislar sobre assuntos de interesse local (art. 30: I) e promover, no que couber, adequado ordenamento territorial, mediante planejamento e controle do uso, do parcelamento e da ocupação do solo urbano (art. 30: VIII).

No entanto, para cada instância do governo foi atribuída uma competência sobre o desenvolvimento territorial reforçando a importância das relações estabelecidas entre os níveis de governo sem a explicitação necessária dos mecanismos de articulação entre as instâncias de governo no ordenamento territorial das grandes metrópoles como a do Rio de Janeiro. No caso, a institucionalização do planejamento metropolitano e os mecanismos de viabilização das políticas de desenvolvimento territorial na metrópole ficaram a cargo da constituição estadual de cada Estado, mas não proporcionou, de fato, grandes avanços na perspectiva do desenvolvimento regional.

Um ano após a promulgação da Constituição Federal, foi promulgada a Constituição do Estado do Rio de Janeiro, em 1989, que, em acordo ao Art. 25 $\S^{\circ}$ da CF88, detalha no Art. $75 \S^{\circ}$ sobre a competência do Estado em, mediante lei complementar, criar Regiões Metropolitanas, Aglomerações Urbanas e Microrregiões, constituídas por agrupamentos de municípios limítrofes para integrar a organização, o planejamento e a execução de funções públicas e serviços de interesse comum, dispondo de um órgão executivo e de um Conselho Deliberativo composto na forma da lei complementar que incluiria representantes dos poderes Executivo e Legislativo, de entidades comunitárias e da sociedade civil. Já o Art. 76 dispõe sobre a formação dos Consórcios [Digite texto] 
Públicos Intermunicipais. De fato, algumas leis complementares $^{83}$ foram promulgadas desde a década de 1990 em reconhecimento da realidade metropolitana, mas sem que houvesse a instituição do Plano Diretor Metropolitano e dos Consórcios Públicos Intermunicipais se tornasse realidade no país.

Em 1989, no governo do prefeito Marcello Alencar, medidas de empréstimos com o Banco Mundial via CEF, e a reforma tributária que permitia um ajuste do IPTU, a cobrança de outros impostos, a colaboração da população, a política salarial da prefeitura e o Plano Verão do governo federal, permitiram ao prefeito sanear as finanças do município. No entanto, o prefeito conseguiu aprovação do aumento dos impostos alegando a reconstrução dos serviços públicos no meio de severas oposições ao governo federal e ao governo estadual, resultando em dificuldades políticas para o futuro da cidade.

O governo do Estado se deparava com uma perda expressiva na arrecadação de impostos, perda dos investimentos privados e aumento da dívida pública interna. A falta de recursos foi alegada pelo governador Moreira Franco na época para justificar a inércia do governo em desapropriar e regularizar os terrenos referentes a algumas favelas, alvo de inúmeras invasões pela população de baixa renda e das correspondentes inúmeras ações violentas contra essas ocupações, pelo governo. A ausência do planejamento do ordenamento territorial e a casuísmo das ações do governo referente aos graves problemas urbanos conduziram aos mais drásticos índices de favelização, desemprego, violência, deficientes serviços públicos e impactos ambientais na cidade.

As relações político-partidárias conflituosas entre governos sempre marcaram os impasses nas transferências de recursos federais e influenciaram as políticas de ordenamento territorial. Os repasses de verbas do governo federal para o município evidenciou uma estreita ligação aos apoios políticos à

\footnotetext{
${ }^{83}$ A Lei Complementar No 64/90 dispunha sobre o Plano Diretor Metropolitano e foi revogada pela Lei Complementar No 87/97 que dispunha sobre a região metropolitana do Rio de Janeiro, sua composição, organização e gestão e sobre a microrregião dos lagos, define as funções públicas e serviços de interesse comum e dá outras providências, que sofreu alteração pela Lei Complementar No 87/98 e mais recente a Lei Complementar No 133/2009 que dispõe sobre a Região Metropolitana do Rio de Janeiro e das Microrregiões dos Lagos e a Lei No 11.107/05 ou Lei dos Consórcios Públicos que trata das normas gerais de contratação de consórcios públicos.
}

[Digite texto] 
época, pela permanência por mais um ano do presidente José Sarney no governo. Moreira Franco (1987-1991), por não ter dado o apoio no documento conhecido como "Carta do Rio de Janeiro" em que governadores manifestaram apoio ao mandato de cinco anos para Sarney e defendiam a manutenção do presidencialismo, levaram a que o Estado do Rio de Janeiro sofresse boicotes aos repasses de verbas do governo federal, comprometendo ainda mais as condições sociais e econômicas da cidade.

Diante das mudanças que estariam por vir com o fim da Guerra Fria, alguns encontros marcaram novos posicionamentos dos governos latinoamericanos diante das novas imposições das economias de mercado, em destaque a reunião sobre "Planejamento Governamental e a Nova Realidade Constitucional" promovido pela Secretaria de Planejamento da Presidência da República em 1989, cujos anais de reunião encontram-se nos documentos selecionados sobre planejamento em economias de mercado do ILPES ${ }^{84}$.

Novas exigências foram impostas ao governo diante de uma nova ordem mundial que se estabeleceu nos anos 90, impondo a diminuição das ações intervencionistas do governo federal nas políticas de ordenamento territorial, apostando na capacidade do município em impulsionar o desenvolvimento local, regional e nacional mediante o fortalecimento político, administrativo e de organização financeira, propiciando sua autonomia mediante ampla e real participação democrática de seus habitantes nos processos de planejamento e tomadas de decisões.

Embora a Constituição Federal de 1988 tenha disposto sobre o papel político do plano diretor no ordenamento territorial, uma nova racionalidade era

\footnotetext{
${ }^{84}$ Os documentos selecionados sobre Planificación em economias de mercado ofereciam algumas bases para o Colóquio Internacional sobre novas orientações para o Planejamento em Economias de mercado e indicavam mudanças no planejamento governamental dos países latino- americanos a partir dos anos de 1990 sob os novos paradigmas da globalização econômica que consistiam na abertura comercial e financeira, na captação de capitais externos para financiar o desenvolvimento, renegociação parcial da dívida externa, redefinir manejo macroeconômico de curto prazo, definir políticas de relacionamento externo para assegurar um ritmo sustentável de crescimento no médio e longo prazos, conformação de um projeto político de desenvolvimento, estreitamento nas relações entre o governo e a sociedade civil, fortalecimento do planejamento em resposta a crise, elaboração de planos de médio a longo prazos, minimização da ação interventora do governo, reformulação dos órgãos nacionais de planejamento em decorrência de reordenamentos legais ou de projetos de reestruturação administrativa e no processo de descentralização das políticas públicas resgatar o município como célula vital para impulsionar o desenvolvimento local, regional e nacional mediante o fortalecimento político-administrativo e de organização financeira, propiciando sua autonomia mediante ampla e real participação democrática de seus habitantes nos processos de planejamento e tomada de decisões.
}

[Digite texto] 
introduzida nas estruturas dos governos locais, apoiadas pelas diretrizes do Consenso de Washington ${ }^{85}$ e dos paradigmas da máxima internacionalização econômica e de competitividade de lugares para se tornarem atraentes aos diversos empreendedores nos chamados planos estratégicos de cidades. $O$ ideário de uma gestão estratégica local impôs total desestruturação do sistema de planejamento no país

Desde a elaboração do plano diretor como preconizado nos anos $90 \mathrm{e}$ dos sucessivos planos estratégicos de cidades, assim como da legislação urbanística, a cidade do Rio de Janeiro tornou-se palco de intensos conflitos das diferentes racionalidades desses instrumentos urbanísticos elaborados no processo de produção e apropriação do espaço urbano. Numerosas mudanças organizacionais dispostas e estabelecidas nos planos estratégicos elaborados pela administração pública local em parceria com o setor privado ocorreram na prática do planejamento urbano $\mathrm{A}$ racionalidade democrática proposta pelo plano diretor deu lugar aos ideários empreendedoristas das ações do governo e do setor privado.

A sobreposição desses instrumentos no direcionamento das políticas públicas na construção do espaço urbano, como o plano diretor, o plano estratégico de cidades e as leis e normas quanto ao uso e a ocupação do solo, contribui ao quadro complexo quanto ao ideário do ordenamento territorial urbano. O plano diretor, o plano estratégico de cidades e a legislação urbanística transformaram a cidade do Rio de Janeiro numa arena de intensos conflitos em sua estruturação e consolidação físico-territorial.

No contexto de mudanças radicais na administração pública local pautada por uma gestão empresarial susceptível aos resultados imediatos a fim de redinamizar a economia local, a visão estratégica da cidade expressa nos planos estratégicos de cidades se sobrepôs às determinações do plano diretor, que incorporara o ideário econômico-social, de participação popular e de

\footnotetext{
${ }^{85}$ Os princípios fundadores do Consenso de Washington foram elaborados em 1989 pelo FMI, Banco Mundial e o Departamento do Tesouro dos Estados Unidos e se tornou a política oficial do FMI nos anos de 1990, indicada aos países em desenvolvimento que passavam por dificuldades financeiras apoiavamse na disciplina fiscal, na reorganização das despesas públicas, a reforma tributária, a liberalização do setor financeiro, na consolidação das taxas de importação e exportação competitivas, a liberalização comercial, mecanismos atrativos para investimentos estrangeiros diretos, a privatização de estatais e a desregulamentação da economia.
}

[Digite texto] 
redefinição das regras de uso e ocupação do solo a fim de fazer cumprir a função social da cidade.

Após um longo período de decadência econômica e social do município do Rio de Janeiro, foi elaborado em $1992^{86}$ o primeiro plano diretor, Plano Diretor Decenal da Cidade do Rio de Janeiro, em conformidade ao artigo 182 da Constituição Federal de 1988 que dispõe sobre a importância do plano diretor na política de desenvolvimento e expansão urbana, executado pelo poder público municipal a fim de ordenar o pleno desenvolvimento das funções sociais da cidade e garantir o bem-estar de seus habitantes. Ao se tornar lei na última Constituição Federal, a elaboração do plano diretor tornou-se ação importante e se insere na lógica de atrair recursos do BID e do Banco Mundial, destinados aos eventos e projetos susceptíveis aos grandes negócios.

O primeiro plano diretor foi uma resposta às exigências da sociedade civil organizada de formulá-lo com base nos artigos 452 a 456 da Lei orgânica do Município ${ }^{87}$ elaborada em 1990. Os referidos artigos dispõem sucintamente que o plano diretor é o instrumento básico da política urbana, é parte integrante do processo contínuo de planejamento municipal, abrangendo a totalidade do território do município e contendo diretrizes de uso e ocupação do solo, zoneamento, índices urbanísticos e áreas de especial interesse, articuladas com os aspectos econômicos, financeiros e administrativos. Todas as etapas do processo de planejamento municipal foram destinadas ao poder executivo com a garantida participação de representantes da sociedade civil organizada e aprovado pela Câmara Municipal. O plano diretor deve estar atrelado ao orçamento municipal e deve respeitar a fisionomia urbana tradicional da cidade.

\footnotetext{
${ }^{86}$ O primeiro Plano Diretor da Cidade do Rio de Janeiro foi instituído pela Lei Complementar No 16 de 1992. De cunho físico-territorial, em seu conteúdo reafirmou o preceito constitucional das funções sociais da cidade; instituiu meios de negociação e participação popular; dispôs instrumentos referentes à Reforma Urbana; propôs um ordenamento do conjunto da legislação urbanística municipal. Considerando as determinações na Constituição Federal de 1988, devemos considerar que o primeiro plano diretor da cidade do Rio de Janeiro no contexto da democratização da política urbana municipal teve seus trabalhos iniciados em 1989, sob a administração de Marcello Alencar, prefeito eleito pelo PDT- Partido Democrático Trabalhista, de base populista fundado por Leonel Brizola de grande representação na política urbana carioca.

${ }^{87}$ A Constituição Federal de 1988 inscreveu pela primeira vez o município como ente da federação e que passou a ser regido por uma lei orgânica que tem caráter de uma constituição municipal. Assim, a competência municipal inscrita na constituição foi ampliada. Entre várias competências, os municípios passaram a promover o ordenamento de seu território, mediante planejamento e controle do uso, do parcelamento e da ocupação do solo urbano.
}

[Digite texto] 
Os objetivos e diretrizes do plano diretor constarão, obrigatoriamente, do plano plurianual e serão contemplados no orçamento plurianual de investimentos.

O primeiro plano diretor da cidade incorporou determinações do PUB RIO da década de 1970, com a divisão territorial do município em AP's- Áreas de Planejamento, em contraposição à anterior divisão em regiões administrativas, e determinou uma "macrodefinição para o zoneamento, deixando as definições das áreas para os Projetos de Estruturação Urbana PEU, institucionalizando-os como instrumento de planejamento complementar.

Foram incorporados ao plano diretor, além dos instrumentos propostos pelo Movimento Nacional pela Reforma Urbana, como o IPTU Progressivo (art. 33 a 37); o reconhecimento da cidade real com a criação de Áreas de Especial Interesse Social (art.107;141 a 145); a criação de programas habitacionais voltados para o estabelecimento do direito social de moradia (art.138 a 167); o solo criado (art. 23 a 27); o estabelecimento de instrumentos de controle de impacto ambiental (art.118 a 121); além da criação de Conselhos Municipais, do reconhecimento do princípio da não remoção de favelas e de participação da sociedade na administração pública da cidade.

$\mathrm{Na}$ última gestão do prefeito César Maia foi sancionado o Decreto No. 28801/2007 com base nos estudos realizados para a revisão do plano diretor e que cria o macrozoneamento da cidade do Rio de Janeiro para orientar as ações de planejamento e de controle do uso do solo do município. Segundo o referido decreto, as macrozonas de ocupação do solo: controlada, incentivada, condicionada e assistida ${ }^{88}$, tem por base as diferentes características da ocupação e estágios de desenvolvimento econômico da cidade, a necessidade de orientar as ações de planejamento urbano e do controle do uso do solo no município em função da situação de ocupação de cada área e a necessidade de orientar o desenvolvimento urbano de acordo com as potencialidades de diferentes áreas da cidade.

\footnotetext{
${ }^{88}$ A macrozona controlada corresponde à Zona Sul, parte do Centro e Alto da Boa Vista. As regras de ocupação são mais restritivas, para evitar maior adensamento populacional; a macrozona condicionada corresponde boa parte da Barra e do Recreio. A liberação de projetos é atrelada a investimentos em infraestrutura, que podem ser públicos ou privados; a macrozona incentivada corresponde a boa parte da Zona Norte e a idéia é que a legislação na região seja mais flexível, para promover a ocupação de vazios urbanos, aproveitando a infraestrutura já instalada; a macrozona assistida corresponde à Zona Oeste, entre Bangu e Santa Cruz e o poder público entra com investimentos de infraestrutura, para incentivar o desenvolvimento da área.
}

[Digite texto] 
Figura 9 - Áreas de Planejamento - Macrozonas de Ocupação

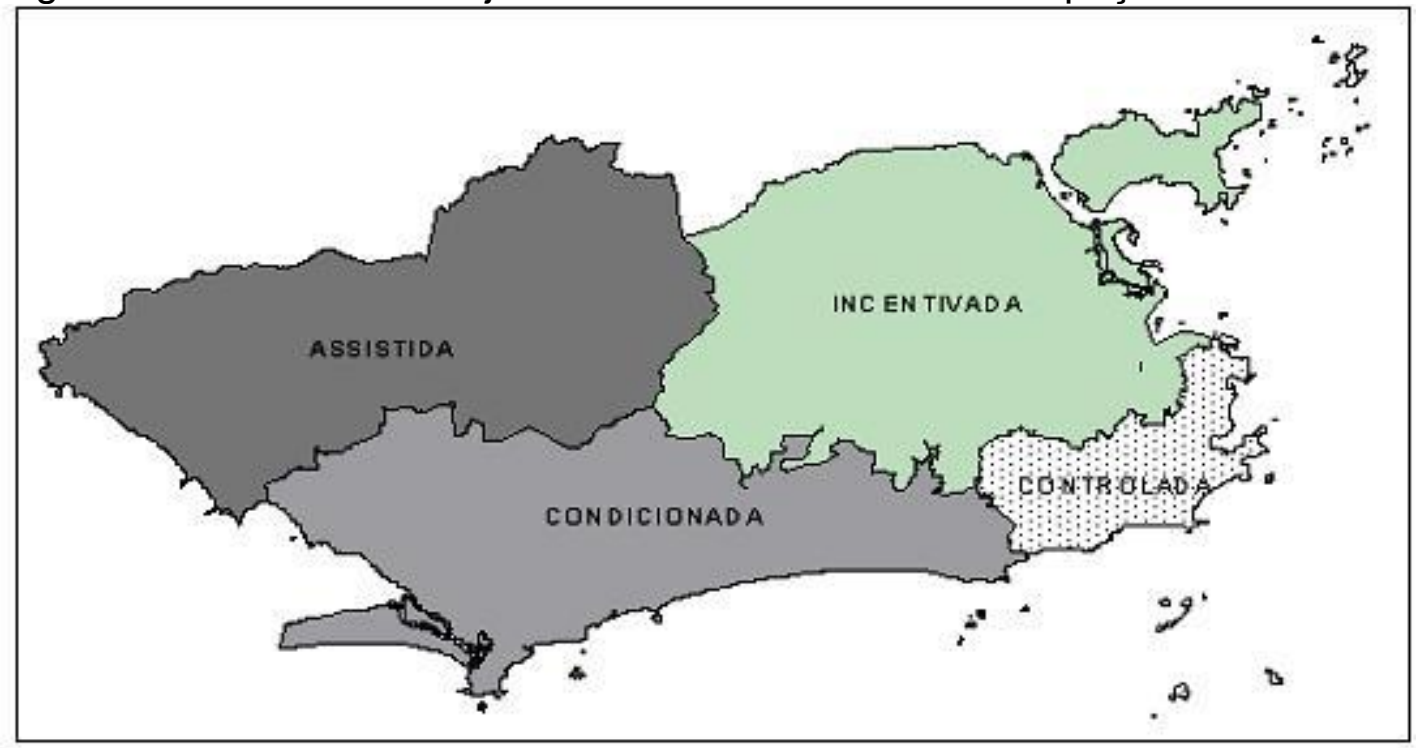

Fonte: www.rio.rj.gov. br.

A conscientização sobre a necessidade de preservação do meio ambiente e de uma mudança da política habitacional nas cidades, assim como de transportes e de urbanização alcançados na década de 1980, resultou nos primeiros esforços de proteção ambiental, somados ao de preservação, reestruturação e desenvolvimento urbanos a partir da Lei Orgânica e do primeiro plano diretor urbanístico estabelecidos em 1992. Os referidos instrumentos buscaram uma aproximação entre o espaço urbano do Rio de Janeiro e seu suporte físico-ambiental às questões sociais, ao tentar compatibilizar o desenvolvimento urbano com a proteção do meio ambiente e a construção de unidades habitacionais para a população de baixa renda, definir e estabelecer critérios para a criação de Unidades de Conservação e Zonas Especiais de Interesse Social para a realização de estudos de impacto ambiental e para a proteção de elementos da paisagem urbana ${ }^{89}$.

\footnotetext{
${ }^{89}$ O primeiro plano diretor urbanístico da cidade do Rio simbolizou o primeiro diagnóstico ambiental: as APA'S- Áreas de Proteção Ambiental; APARU'S- Áreas de Proteção Ambiental e Recuperação Urbana; as APAC'S- Áreas de Proteção do Meio Ambiente Cultural; áreas de relevante interesse ecológico; as reservas biológicas; as estações ecológicas; os parques e as APP'S- Àreas de Preservação Permanente. Toda legislação estabelecida em âmbito municipal foi considerada uma das mais avançadas dos país. Tempos depois, o SNUC - Sistema Nacional de Unidades de Conservação da Natureza foi instituído pela lei federal 9985/2000 que definiu o Grupo das Unidades de Uso Sustentável. As ZEIS- Zona Especial de Interesse Social são porções do território destinadas prioritariamente, à recuperação urbanística, à regularização fundiária e produção de Habitações de Interesse Social - HIS ou Habitações do Mercado
}

[Digite texto] 
A reforma tributária com base na última Constituição Federal, ao reduzir consideravelmente os recursos dos Estados, que passaram a não cumprir com os crescentes gastos e viram agravada essa situação pela autonomia concedida em determinar alíquotas e conceder isenções do ICMS. A ausência de uma legislação capaz de regulamentar as isenções do imposto, reforçou a chamada guerra fiscal entre Estados com sérios comprometimentos das receitas e muitas dificuldades para cumprir com o encargo de realizar políticas de desenvolvimento regional. No governo de Marcello Alencar (1995-1998), a situação administrativa insustentável do Estado, inclusive pelas denúncias de desfalques nas contas públicas, os alarmantes índices de violência, o déficit orçamentário, levou o governador a propor estudo de viabilidade de decretar o estado de defesa no Rio de Janeiro, previsto pelo art. 136 da Constituição Federal e apoiado na época pelo presidente Fernando Henrique Cardoso.

Ao longo do governo de Marcello Alencar (1995-1998), várias medidas de privatização foram tomadas justificando-se pela substituição dos métodos anacrônicos de governo por novas práticas gerenciais que seriam 0 pressuposto da modernização do aparelho estatal. Inúmeras empresas estaduais foram privatizadas, mas sem a garantia da melhoria dos índices sociais e econômicos do Estado.

Em contraposição à crítica situação financeira do Estado, a prefeitura do Rio de Janeiro encontrava-se em situação de superávit orçamentário por conta de políticas rigorosas de contenção de despesas e pelo reajuste nos valores dos impostos no governo de César Maia (1993-1997), que permitiu sucessivas obras de cunho urbanístico na cidade. A incompatibilidade política entre os governos municipal e estadual resultava em duras críticas de César Maia ao governo de Marcelo Alencar, em prejuízo à elaboração de políticas integradoras e, por conseguinte impedindo maiores avanços nas políticas de integração e institucionalização da região metropolitana.

Os governos de César Maia (1993-1997,2001-2005,2005-2009) e Luiz Paulo Conde (1997-2000) simbolizaram uma ruptura da política municipal até

Popular - HMP incluindo a recuperação de imóveis degradados a provisão de equipamentos sociais e culturais, espaços públicos, serviços e comércio de caráter local. As ZEIS são definidas pela legislação urbanística e principalmente as chamadas Leis de Uso e Ocupação do Solo ou Leis de Zoneamento. (www.usp.br/fau/depprojeto/labhab/biblioteca/produtos/acesso-solo-zeis.pdf)

[Digite texto] 
então em vigor e o suposto fim de um longo período de dominação de forças populistas no Rio de Janeiro. Adotaram uma política urbana fora dos órgãos de planejamento urbano e regional comandada por projetos pontuais que se valiam do discurso do marketing urbano e dos recursos disponibilizados pelas agências financeiras multilaterais.

No contexto de mudanças radicais na administração da cidade, entidades privadas $^{90}$ foram criadas com a finalidade de agilizar a promoção e gerenciamento de contratos de concessão de utilização dos espaços urbanos, captar recursos privados para a realização de projetos intermediando as negociações entre o poder executivo municipal e o empresariado. Novos modelos administrativos e intervencionistas, inseridos numa tendência de maior competitividade, foram implantados para alicerçarem os chamados Planos Estratégicos de Cidades.

Segundo Amendola (2002:33) o Plano Estratégico de Cidades, na verdade, é uma operação de marketing da cidade que tem por objetivo torná-la competitiva, para a sua inserção na economia global como centro do setor terciário superior. Portanto, as qualidades de vida, cidadania e cultura estão assim mais relacionadas à questão da imagem para a promoção da cidade junto ao mercado externo e, consequentemente, para atrair investimentos, do que amenizar os conflitos sociais gerados pela escassez de postos de trabalho e pela queda da qualidade de vida, típicos das grandes cidades. A busca dessa imagem está associada à busca da competitividade da cidade na disputa com outras por novos investimentos.

A elaboração do primeiro plano estratégico para a cidade do Rio de Janeiro veio no bojo das radicais mudanças administrativas e intervencionistas locais em vista de imediatas medidas para a recuperação econômica da cidade tendo por fonte inspiradora o caso de Barcelona. ${ }^{91} \mathrm{Na}$ tentativa de impor uma

\footnotetext{
90 Inicialmente a administração municipal enviou ao legislativo o Projeto de Lei Complementar No 01 de 1997 que instituía o Programa de Desenvolvimento Urbano e autorizava a criação da Companhia de Desenvolvimento Urbano que transferiria ao setor privado as prerrogativas públicas de legislar, executar obras e de dispor do patrimônio imobiliário municipal, mas que pela forte reação contrária ao projeto, foi substituída pela Agência de Desenvolvimento da Cidade denominada de Agência Rio, criada pelos empresários que participaram da elaboração do Plano Estratégico da Cidade, funcionou de 1997 a 2000 viabilizando a realização dos projetos urbanos.

91 O tema foi desenvolvido pela autora na dissertação de mestrado em Ordenamento Territorial e Ambiental do curso de Pós-Graduação de Geografia da UFF- Universidade Federal Fluminense em 2002,

[Digite texto]
} 
ordem à cidade, a proposta inicial do plano estratégico era disciplinar o espaço urbano. Algumas políticas públicas apoiavam-se na reconquista do espaço público, estimulando conflitos urbanos, lançando mão de mecanismos para expulsar os comerciantes ambulantes informais e interagindo com projetos de embelezamento da cidade. A questão administrativa apoiava-se em programas de terceirização/privatização visando desonerar os encargos do governo e a implementação da reengenharia nos órgãos de governo, substituindo o modelo verticalizado, com muitas funções de controle e altamente burocratizado, por uma organização supostamente mais flexível, ágil e descentralizada.

Ao lançar o primeiro plano estratégico da cidade em 1995, como instrumento de um acordo estabelecido com a ACRJ- Associação Comercial do Rio de Janeiro e com a Firjan- Federação das Indústrias do Estado do Rio de Janeiro, contou com a participação das sociedades privadas e diferentes associações patronais que instauraram um grupo organizador do Plano Estratégico da Cidade do Rio de Janeiro - Rio Sempre Rio, assegurando os recursos para o financiamento das atividades e particularmente para firmar 0 contrato com os experientes urbanistas internacionais, Jordi Borja e Manuel Castells, que então se encarregaram da direção executiva do plano. Outras estruturas foram instaladas, como o Conselho da Cidade, o Conselho Diretor, o Comitê Executivo, que contavam com a participação do setor empresarial, setores do governo e da sociedade civil organizada.

Para o governo municipal, o plano simbolizou um corte nas tendências do passado, que primeiro consideravam os governos federal e estadual para assistir as condições econômicas dos cidadãos e seu bem-estar; para avistar o setor privado e as organizações não governamentais como parceiros mais importantes no progresso. Embora contemplasse poucos municípios constituintes da região metropolitana, determinados projetos concentraram-se no município do Rio de Janeiro, em contraposição aos demais municípios de sua respectiva região metropolitana. A maioria dos projetos explícitos no plano

titulado "Uma Leitura Geográfica dos Planos Estratégicos da Cidade do Rio de Janeiro" que realiza uma correlação entre os planos estratégicos de Barcelona e os planos estratégicos da cidade do Rio de Janeiro avaliando seus respectivos impactos econômicos, urbanísticos, infraestruturais, sociais, ambientais, turísticos na perspectiva do ordenamento territorial.

[Digite texto] 
estratégico se contrapôs às idéias do Banco Mundial ${ }^{92}$ de considerar a metrópole como um espaço importante de crescimento econômico.

O plano estratégico do governo César Maia foi anunciado como um pacto social apoiado na parceria público/privado a fim de ampliar as "potencialidades" da cidade e torná-la atraente aos investidores. Assim, foi apresentado como sendo de natureza menos normativa e mais participativa que 0 plano diretor e tornar-se-ia 0 instrumento de referência da política municipal de sua administração. Segundo o plano, a nova forma de gestão levaria a cidade a ser considerada uma metrópole competitiva e empreendedora e um centro científico de negócios internacionais. O plano não menciona estar inserido em algum contexto de planejamento do governo. A cidade passou a ser administrada por projetos pontuais dissociados da perspectiva de planejamento urbano e regional.

Alguns projetos foram emblemáticos na política urbana da administração de César Maia como: o Projeto Rio Cidade, que consistiu na urbanização de bairros, a construção da Linha Amarela, a ampliação da linha do metrô, o Teleporto, o Favela-Bairro, entre outros concentrados na metrópole. O ideário do referido projeto apoiava-se na requalificação dos eixos estratégicos de circulação viária da cidade, promovendo a melhoria da infraestrutura e seu funcionamento. Por sua vez, o Projeto Favela Bairro visava criar condições de incorporar as favelas ao tecido urbano de modo a não apenas instaurar os serviços públicos nesses espaços, mas principalmente permitir a acessibilidade a esses locais e consequentemente viabilizar a regularização fundiária. $O$ projeto se tornou mais conhecido pelas intervenções urbanísticas do que pelas conquistas sociais.

A tentativa de regularização fundiária dos terrenos da favela com o Projeto Favela Bairro não foi muito bem sucedida pelo ineficiente cadastro imobiliário, que se mostrava semi-privado, complexo e passível de corrupção. Tal constatação indica como a ausência de um adequado cadastro dificulta a integração desse sistema à política urbana de regularização fundiária; além da dinâmica do número de habitações informais, os elevados valores e a

\footnotetext{
92 Rio de Janeiro: a city study (vol 1 e 2)- 1999 in Banco Mundial- Publicações Brasil - Pobreza e Sociedade- HTTP://web.worlbank.org.
}

[Digite texto] 
burocracia de registrar a propriedade. Essa realidade se agrava pela falta de interesse dos setores ligados ao mercado imobiliário informal que reforçam os entraves para legalizar "o ilegal" e garantir o direito à habitação das parcelas desfavorecidas da sociedade.

A gestão César Maia inaugurou uma forma de conceber os problemas urbanos de forma desintegrada do todo e receptores de tratamento setorializado nos órgãos do governo. Cada questão foi entregue a um determinado setor que tomava as decisões de modo a atender aos interesses predominantes que dessem maior visibilidade à cidade em detrimento de soluções mais efetivas e benéficas à maior parte da população. Quanto à necessidade premente de ordenar os espaços das favelas, a questão foi entregue ao GEAP- Grupo Executivo de Assentamento Popular da Secretaria Municipal de Habitação que tinha por objetivo concentrar todas as ações municipais sobre expansão de favelas e de loteamentos informais da periferia. Esse grupo deveria definir as ZEIS- Zonas Especiais de Interesse Social, em vista de instaurar vasto projeto de regularização fundiária e estudar os tipos de ocupação do solo da cidade a fim de formular alternativas legais, institucionais e fiscais susceptíveis de aumentar o acesso à habitação.

Considerando as perdas significativas de recursos fiscais municipais provocadas pelas irregularidades urbanísticas e pela ausência de controle de dados periodicamente atualizados de propriedade do solo urbano ao longo dos anos, a administração pública do governo César Maia buscou mecanismos para transformar as favelas em espaços passíveis de arrecadação de impostos e a população favelada em potenciais contribuintes. Os diversos mecanismos de intervenção do governo nas favelas sob o discurso de integrá-las à cidade visavam garantir recursos aos cofres do município. De modo a reduzir os encargos do governo local, a prefeitura delegou alguns serviços de sua alçada às ONG's - Organizações Não Governamentais, permitindo a continuidade das relações clientelistas tão típicas ao longo da história da cidade do Rio de Janeiro.

O governo estadual se deparava com elevado déficit das contas públicas e continuava sempre voltado para as questões do município do Rio de Janeiro, e a situação de crise social caracterizada pelas altas taxas de violência, desemprego e estagnação econômica fez com que o governo solicitasse [Digite texto] 
empréstimos ao governo federal para adotar medidas repressivas sem grande alcance na melhoria das condições sociais. As políticas sociais seriam centralizadas em um único programa de transferência de renda: o Bolsa Família, reforçando a influência direta dos repasses de recursos da União aos municípios e excluindo o Estado desse processo.

As mudanças ocorridas na dinâmica da estruturação da cidade e 0 incremento no número de representantes da sociedade civil passaram a expor os interesses destes últimos, transformando a administração urbana em uma grande arena de conflitos de interesses. A ausência de um sistema de planejamento adequado à dinâmica da cidade reforçou uma expansão da mesma sem diretrizes, permitindo improvisações, estagnação da dinâmica social e econômica, ocupações irregulares sujeitas às calamidades, sobrecarga da infraestrutura e serviços urbanos, uso indevido dos instrumentos urbanísticos, desperdício de recursos do governo.

Após a elaboração do Estatuto da Cidade em 2001, lei federal de desenvolvimento urbano, exigida constitucionalmente e regulamentadora dos instrumentos urbanísticos, tributários e jurídicos, foi reforçada a importância do plano diretor na elaboração das políticas urbanas na esfera municipal, para o cumprimento da função social da propriedade urbana. Somente no ano de Desenvolvimento Urbano Sustentável do Município do Rio de Janeiro - ou Lei Complementar No 111/2011, com um atraso de quase vinte anos, num processo envolto em conflitos de interesses, tendo por intenção principal oferecer as necessárias diretrizes de crescimento da cidade numa retomada da importância do papel do plano diretor no ordenamento territorial urbano.

O novo plano diretor caracterizou-se pela definição de instrumentos úteis à gestão, mas inovou negativamente ao tratar a cidade genericamente deixando de observar suas espacialidades identitárias. É inegável que o quadro político institucional não favoreça o compartilhamento decisório na construção da cidade numa perspectiva integrada. Antes, aceita um compromisso difuso com a cidade como se vê no atual plano diretor generalista. Tendo mais de 300 artigos, apenas três deles $(33,117,163)$ citam ambientes do Rio. Os demais artigos poderiam se aplicar a muitas cidades. Temas relevantes ficaram fora da lei. 
Ao ser a cidade do Rio de Janeiro eleita uma das cidades brasileiras para sediar a Copa do Mundo de 2014 e os Jogos Olímpicos e Paraolímpicos de 2016, foi desencadeado outro rumo das políticas urbanas, incorporando o ideário empreendedorista na administração local e delegando as diretrizes dos investimentos urbanos às entidades internacionais e nacionais como a $\mathrm{COI}$ Comitê Olímpico Internacional, a FIFA - Federação Internacional do Futebol, o COB- Comitê Olímpico Brasileiro, a EOM- Empresa Olímpica Municipal, entre outras. A fim de "capacitar" a cidade aos referidos eventos, o governo local sancionou o Decreto No 32886/2010 que define o "Legadômetro" e determinou as diretrizes a serem observadas na avaliação das intervenções urbanas e dos equipamentos esportivos e de apoio, seguindo o disposto pelas macrozonas de ocupação do solo.

A fim de criar os mecanismos para legitimar os chamados grandes projetos urbanos para sediar a Copa do Mundo de 2014 e os Jogos Olímpicos e Paraolímpicos de 2016, foi elaborado o Legado Urbano cujos projetos serão analisados pela Comissão de Avaliação dos Projetos de Legado Urbano a ser composta por representantes das Secretarias Municipais de Urbanismo, de Meio Ambiente, de Transportes e de Obras, e que emitirá parecer preliminar a respeito, sem prejuízo das análises técnicas a serem feitas pelos órgãos de licenciamento da prefeitura.

Segundo o Decreto No 32886/2010, as análises feitas pela comissão deverão considerar aspectos econômicos, sociais, ambientais, paisagísticos, de circulação de veículos, estéticos e de adequação das construções aos padrões de sustentabilidade e de conforto ambiental. Os chamados Projetos de Legado Urbano serão submetidos a futuras avaliações sobre seus impactos. As normas urbanísticas e ambientais para construção de equipamentos e instalações serão objeto de decreto a ser publicado pelo poder municipal.

A escolha da cidade como sede da Copa do Mundo de 2014 e dos Jogos Olímpicos de 2016 vem estimulando uma profusão de projetos inspirados em experiências estrangeiras que objetivam melhorias nas cidadessedes, mas com a preocupação de deixar um legado, aproveitando o momento de muitos investimentos no Rio. Os projetos olímpicos impõem uma nova lógica intervencionista na metrópole, que se sobrepõe a uma realidade 
expressa territorialmente nas relações sociais estabelecidas num processo histórico e político de construção do espaço ao longo dos anos.

O pacote olímpico prevê emendas do legislativo nas propostas que viabilizem os investimentos aguardados pelo governo, que se utiliza de incentivos aos setores considerados fundamentais para as intervenções urbanísticas e de infraestrutura para a cidade sediar os eventos, como a rede hoteleira, de construção civil, de turismo entre outras. Os incentivos concedidos pela prefeitura correspondem às isenções ou abatimentos em tributos municipais como IPTU - Imposto Predial e Territorial Urbano, ISS - Imposto sobre Serviços e ITBI - Imposto de Transmissão de Bens Intervivos, direcionados aos setores empreendedoristas.

Os chamados "Grandes Projetos Urbanos" e os "Projetos de Revitalização" direcionam os investimentos na cidade a fim de prepará-la aos futuros eventos mundiais. Destacamos a projeto Porto Maravilha, que se propõe revitalizar a zona portuária a partir de alterações urbanísticas locais e de marketing urbano a fim de torná-la atraente aos investimentos futuros. 0 governo local conta em atrair recursos de investidores para a região portuária a partir de manobras estratégicas para recuperar essas áreas degradadas da cidade.

De modo a adaptar o espaço urbano às exigências dos eventos, o pacote olímpico, quando encaminhado pelo governo local à Câmara dos Vereadores, recebeu emendas do legislativo nas propostas que tratam de incentivos aos setores considerados imprescindíveis ao evento e de que a cidade não dispõe, como no caso da rede hoteleira. O governo local propôs que incentivos fiscais oferecidos pela prefeitura (isenções ou abatimentos em IPTU, ISS e ITBI) para a construção de novos hotéis até dez de 2015 sejam estendidos também para empreendimentos que se encontram inacabados.

Cabe lembrar que história do Rio de Janeiro, há mais de cem anos, é indissociável das favelas. No começo, foram consideradas efêmeras, problema que o desenvolvimento do país equacionaria. Lei de 1937 proibiu que o mapa da cidade incluísse suas favelas. Quando ultrapassavam as centenas, passouse à política de remoção compulsória. A reação social a inviabilizou. Não sem antes produzir grandes guetos localizados nas fraldas da cidade e que após quarenta anos, ainda são lugares isolados e de muita pobreza. A revisão 
política dos anos 1980 reconheceu as favelas como realidade social e urbanística. Implantaram-se as primeiras redes sanitárias. Como já referido, em meados da década de 90, a partir de uma revisão doutrinária, a prefeitura do Rio iniciou o Programa Favela Bairro com financiamento do BID e da Caixa Econômica Federal na suposta tentativa de inseri-las no contexto urbano.

Ao longo do tempo, as estratégias públicas para as favelas basearam-se na política de remoção/assentamento de elevado custo aos cofres públicos sem se inserir numa perspectiva maior de uma política nacional de habitação no contexto do ordenamento territorial ${ }^{93}$. Embora as remoções tenham adquirido um discurso de justiça social, as políticas públicas se voltaram para a reurbanização e regularização fundiária das favelas, sem grandes e efetivos resultados. A descontinuidade das políticas públicas direcionadas às favelas é atribuída aos sucessores no governo que não prezam pela continuidade dos projetos vinculados ao político antecessor.

No contexto do legado urbano de preparar a cidade para os eventos de 2014 e 2016, foi lançado pela prefeitura da cidade do Rio de Janeiro, o Programa Morar Carioca ou o Plano Municipal de Integração de Assentamentos Precários Informais de Baixa Renda de reurbanização das favelas, como continuação do Programa Favela Bairro que não solucionou a problemática das ocupações irregulares e seu crescimento. O referido programa conta com os recursos do BID, do Banco Mundial, de repasses do governo federal, estadual e municipal e de parcerias público-privadas num total de $R \$ 8$ bilhões até o ano de 2020. A prefeitura intenciona ser um programa mais aperfeiçoado que o anterior a partir de ações de equipes das Secretarias Municipais de Conservação, Ordem Pública, Urbanismo e Habitação efetuadas

\footnotetext{
${ }^{93}$ As obras para urbanizar favelas e ocupações irregulares, além da remoção de famílias de áreas de risco na cidade nos últimos anos, vem onerando os cofres públicos principalmente nos projetos de grande porte como o Favela-Bairro, Bairrinho e Programa de Aceleração de Desenvolvimento. Até a década de 1980, a principal política era a remoção dos moradores para áreas distantes, sem efetivos resultados já que os conjuntos habitacionais construídos foram favelizados por falta de políticas públicas adequadas. A situação mudou a partir do primeiro governo Leonel Brizola (1983-1986), que passou a investir em programas de urbanização e regularização fundiária, sem grandes resultados. Em 1992, a Lei Orgânica do Município incluiu um dispositivo que impede as remoções sem indenizações ou reassentamento em locais próximos, exceto em áreas non aedificandi (onde é proibido construir), que possam pôr a vida do morador em risco, como encostas, e em faixas de proteção de rios e lagoas. Em 2004, as mudanças no orçamento público impediram a conclusão de muitas obras do Favela Bairro que ficaram incompletas ou se degradaram com o tempo.
}

[Digite texto] 
com o fim de restringir o crescimento horizontal das favelas, com base nos estudos elaborados pelo IPP - Instituto Pereira Passos e da presença dos chamados POUSOS - Posto de Orientação Urbanística e Social que controla e fiscaliza a expansão das favelas.

O Projeto Morar Carioca para reurbanizar todas as favelas do Rio até 2020 prevê um objetivo ousado que se compõe ao legado social dos grandes eventos que a cidade sediará. O Morar Carioca procura aproveitar as diversas experiências das últimas décadas, seus erros acertos e desvios de rumo, buscando ampliá-las, no objetivo da superação plena desse enorme desafio de integração social e urbanística.

O Morar Carioca prevê remoções de favelas que se encontram em áreas de risco. A população removida será direcionada para conjuntos habitacionais construídos com os recursos do PAC, do governo federal, do Programa Minha Casa, Minha Vida lançado pelo governo federal em 2009 e que conta com a linha de financiamento pela Caixa Econômica Federal, concessão de incentivos fiscais e tributários pelo município do Rio para esse tipo de obra, direcionada para a Zona Norte e Oeste e subúrbio da cidade a fim de atender a demanda reprimida.

Concomitantemente ao programa Morar Carioca de urbanização das favelas em função dos grandes eventos esportivos em 2014 e 2016, o legado social dos jogos olímpicos prevê a remoção de aproximadamente 123 comunidades até 2012, consideradas localizadas em áreas de risco e que paradoxalmente encontram-se nas proximidades das vias de acesso aos estádios esportivos que sediarão os eventos. Pelo imediatismo das ações dos órgãos do governo local e pela falta de planejamento, as medidas de remoção não são acompanhadas pelo necessário número de habitações para atender a demanda. De modo a restringir a expansão espacial das favelas na cidade, a prefeitura vem lançando mão de fotos aéreas e satélites, de áreas ocupadas para identificar novas invasões de ano em ano, pouco atentando para uma necessária política habitacional relacionada ao ordenamento do espaço urbano. A Secretaria de Ordem Pública tem como prioridade combater 0 crescimento horizontal das comunidades com base nos estudos feitos pelo IPP- Instituto Pereira Passos para delimitar as áreas. 
As idéias e propostas para a reurbanização das favelas contam com a histórica presença do IAB - Instituto de Arquitetos do Brasil na escolha dos escritórios de arquitetura responsáveis pelas idéias e propostas e da elaboração de decretos para fixar regras de expansão das favelas. Em oposição ao Programa Favela-Bairro, o Programa Morar Carioca está focado na manutenção da infraestrutura implantada, na contenção do crescimento desordenado das favelas e na racionalização de equipamentos públicos e em estender os mesmos serviços públicos às favelas até 2020 fixando regras para cada favela. Todas as secretarias do governo seguem regras para conter a expansão ilegal das favelas, inclusive com a presença dos POUSOS ${ }^{94}$. No caso de favelas não urbanizáveis por se localizarem em áreas consideradas de proteção ambiental ou de risco estaria prevista a remoção dos moradores que deverão ser beneficiados pelo Programa Minha Casa, Minha Vida.

Por quase vinte anos, a cidade do Rio de Janeiro observou a legislação editada na década de 1970 para o ordenamento do território e o controle de seu uso e ocupação apesar de ter sofrido algumas alterações pontuais, chamadas de "projetos urbanos" mediante interesses de agentes públicos e privados na construção e consolidação do espaço da cidade. Até os dias atuais, os "projetos urbanos" de cunho urbanístico se contrapõem ao propósito do planejamento urbano e às determinações do plano diretor, instrumento legal da política urbana. A maioria desses projetos que regem intervenções pontuais na cidade são resultado dos interesses dos grupos influentes e com o apoio do governo até mesmo burlam a legislação urbanística a partir de decretos que alteram as determinações das normas urbanísticas a fim de viabilizá-los.

Os longos anos de oposição do governo municipal do Rio de Janeiro ao governo estadual e federal dificultaram os investimentos públicos e privados na cidade. O problema habitacional se agravou principalmente nos grandes centros a ponto das tensões sociais se acirrarem. As tentativas de regularização dos terrenos ocupados ilegalmente na cidade se deparavam com

\footnotetext{
94 Pouso - Posto de Orientação Urbanística e Social, pertence à SMU- Secretaria Municipal de Urbanismo e insere-se no contexto da administração descentralizada do governo local apoiada no discurso de atender as necessidades desses espaços informais. Tem por objetivo promover a regularidade urbanística dentro das favelas beneficiadas pelo programa Favela Bairro. O objetivo principal seria a consolidação desses bairros e sua integração à cidade. As obras são supostamente fiscalizadas e trabalhos sociais são desenvolvidos de forma participativa dos moradores
}

[Digite texto] 
ações de expropriação/usucapião incapazes de darem uma resposta satisfatória pela grande defasagem jurídica quanto à ocupação do solo. Tais instrumentos legais, previstos como meios de regularização fundiária tornaramse inaplicáveis pela incompatibilidade da legalidade desses instrumentos sobre uma situação de ocupação ilegal fora do devido controle do governo e pela complexidade da situação; seu cumprimento exigiria procedimentos administrativos e jurídicos do governo que criaria situações conflitantes com interesses de setores da sociedade.

Consideramos o intenso conflito deflagrado no processo de dominação, ocupação e expansão do espaço urbano carioca e intensificado após a elaboração do plano diretor que por sua vez, estabelece diretrizes nesse processo sobre o território com acentuadas influências nas relações sociais, que se estabelecem distantes de um considerável consenso. No entanto, percebemos que o planejamento urbano praticado no Rio de Janeiro adquiriu características peculiares quanto ao arcabouço legal inscrito no plano diretor e as normas específicas e pontuais que na maioria das vezes se sobrepõem ao estabelecido para a cidade, resultando num retrato multifacetado do planejamento urbano carioca.

Os conflitos daí deflagrados são numerosos, mas basicamente inseridos na superposição de normas que revogam ou alteram as anteriores, pela vulnerabilidade das influências das visões que passam a predominar ao longo da história do pensamento urbanístico, como inicialmente da higienista/sanitarista; da modernista; da aparência do conjunto urbano; da divisão do território em áreas de planejamento com funções e padrões similares, mas que recebem "tratamentos" diferenciados pelo poder público e privado; do ordenamento das atividades de usos; da delimitação entre o domínio público e privado; das sucessivas mudanças no tecido urbano para beneficiar os ganhos da iniciativa privada; da tentativa de solução do problema habitacional de classe proletária a partir do estabelecimento dos padrões mínimos de habitabilidade; dos princípios da sustentabilidade; do embate das dimensões social, cultural e ambiental da cidade e o direito à propriedade; da informalidade e da ilegalidade das relações que se estabelecem ao acesso à terra urbana, entre outras. 
A história do ordenamento territorial da cidade do Rio de Janeiro evidencia numerosos conflitos expressos territorialmente entre os interesses dos setores imobiliários e investidores, que diante da escassez de terrenos assistidos pela limitada infraestrutura urbana pressionam o governo que tende a desconsiderar leis e normas. As políticas de urbanização e regularização das favelas, baseadas nos princípios da função social da propriedade urbana elaboradas pelo governo, estiveram sempre acompanhadas pela necessidade de remoção pelo perigo iminente de desabamento das casas e de desapropriação para viabilizar a execução de projetos. Tal discurso escondia interesses de concessão de áreas para edificações ou a incapacidade ou simplesmente falta de interesse político em estender a infraestrutura mínima a esses locais.

A partir da exigência de se elaborar um plano diretor para cidades com mais de vinte mil habitantes como o principal instrumento de planejamento urbano indicado na Constituição Federal de 1988 e anos depois, ratificado pelo Estatuto da Cidade, o plano diretor incorporou teoricamente a responsabilidade de diagnosticar e solucionar os grandes problemas da cidade. Diante da complexidade de uma metrópole como o Rio de Janeiro, o plano diretor como principal instrumento de planejamento, asseguraria em longo prazo um desenvolvimento urbano sustentável; mas na realidade evidencia certa incapacidade de conciliar interesses de diversos segmentos da sociedade, resumindo-se numa coletânea de propostas por vezes surreais, demasiadamente ideológicas e à parte da complexa realidade da cidade.

Consideramos que a cidade é resultado de uma espacialidade de conflitos e contradições que a modificam permanentemente por razões de diversas naturezas. O plano diretor é um conjunto de políticas urbanas que foi transformado em lei municipal, com a função de diagnosticar problemas inerentes à expansão urbana das cidades e, subsequentemente, estabelecer metas para compatibilizar o crescimento com os aspectos físico-territoriais, sociais, econômicos, culturais, ambientais e políticos envolvidos nesse processo. O plano diretor apresentaria projeções futuras que incorporariam os ideários de construção de uma cidade plural, democrática e coerente com suas vocações e potencialidades a partir da realização de debates com os diversos 
representantes da sociedade organizada com o objetivo de melhor conhecer e avaliar as demandas da população.

No entanto, reconhecemos o quanto o quadro político institucional desfavorece o compartilhamento de decisões na construção da cidade ideal e o quanto o plano diretor adquiriu caráter generalista pelo desconhecimento do legislador das peculiaridades do lugar. Daí, os compromissos firmados são difusos dando margem às interpretações que favorecem determinados interesses especulativos de segmentos da sociedade. As pressões de diversos segmentos da sociedade para alterar o conteúdo do plano diretor da cidade em vista dos recursos e investimentos previstos com os eventos da Copa e das Olimpíadas, transgrediram princípios básicos do ordenamento territorial da cidade.

O ordenamento territorial do município disposto no plano diretor deveria estar em conformidade com os vetores de crescimento da cidade, 0 macrozoneamento e as diretrizes de uso e ocupação do solo que indicariam os padrões de ocupação urbana a serem adotados no processo de adensamento e de expansão da cidade, as prioridades de investimentos e os instrumentos que seriam aplicados no controle do desenvolvimento urbano. A ordenação do território observaria também as condições ambientais, tendo como referência as bacias e sub-bacias hidrográficas definidas pelos maciços montanhosos e baixadas.

Após inúmeras manifestações de interesses conflituosos, o texto final do plano diretor impõe mudanças urgentes na legislação urbanística da cidade para que as regras estabelecidas sejam efetivamente importantes para 0 planejamento da cidade. A cidade foi dividida em quatro grandes macrozonas para o planejamento e aplicação de políticas públicas que determinam, por exemplo, onde o adensamento deve ser estimulado ou desencorajado com medidas que dificultem a construção de novos prédios. A macrozona controlada (zona sul e parte do centro) tem como características reunir regiões de boa infraestrutura e densamente povoadas. Nelas devem ser desestimuladas novas construções. A macrozona incentivada (zona norte, porto e parte de Jacarepaguá) inclui áreas que dispõem de boa infraestrutura, onde há espaço para incentivar a construção de moradias. A macrozona assistida (entre Bangu e Sepetiba) inclui regiões onde a infraestrutura é [Digite texto] 
insuficiente e exige investimentos públicos, pois a população tem baixo poder aquisitivo. A macrozona condicionada (Barra, Recreio, Guaratiba e Vargem Grande) reúne regiões com infraestrutura deficiente, onde novas licenças para prédios serão condicionadas a investimentos prévios, públicos e privados, em obras de infraestrutura.

O atual plano diretor, Lei Complementar No. 111 de $1^{\circ}$ de fevereiro de 2011, passou por inúmeros substitutivos e inúmeras emendas pouco antes de sua aprovação, demonstrando favorecimento aos interesses da especulação imobiliária e total desrespeito com a sociedade. Quando a prefeitura propõe um PEU-Projetos de Estruturação Urbana (os PEU's são instrumentos legais que fixam regras como gabarito, áreas mínimas que os imóveis devem ter e que tipos de atividades econômicas (comercial ou industrial) são permitidas em cada rua ou avenida), considerando o efeito que ele terá na estratégia de planejar e desenvolver a cidade como um todo. A mesma visão macro não é compartilhada pelo legislativo que insistentemente se queda às pressões para alterarem as regras urbanísticas e permitir intervenções em desajuste com as definições estabelecidas no plano diretor.

$O$ atual plano diretor dificulta novas construções em áreas de risco, como encostas e margens de rios, incorporando o conceito de que a paisagem da cidade, encravada entre o mar e a montanha, é o seu maior bem e deve ser protegida. Assim, a ocupação urbana que no plano anterior não estava subordinada a esse conceito, passou a ser condicionada à preservação de morros, florestas, orla marítima e margens de rios e lagoas. A lei atual, em vigor desde 1992, já previa restrições à ocupação de morros e das faixas de proteção de cursos d'água, mas enfatizava mais o direito à habitação do que a repressão ao crescimento considerado desordenado da cidade. A proibição de novas ocupações nas áreas de risco e a impossibilidade de regularizações nessas áreas são citadas explicitamente. E o desenvolvimento urbano deve passar a considerar a paisagem, preservando-a e protegendo-a.

O plano diretor anterior refletiu conceitos da Constituição Federal de 1988, que por ter um clima de repúdio ao autoritarismo instituiu uma série bastante grande de direitos ao cidadão. O princípio era o da não remoção de moradores das áreas de risco. Nesse caso cabia ao poder público provar que havia risco e quase sempre a questão acabava na justiça. $O$ atual plano diretor 
propõe maior controle das áreas de risco, mas não necessariamente cria os meios para a remoção automática de favelas ou prédios que obstruam a paisagem natural. No caso das favelas, o plano permite que ocupações consolidadas sejam mantidas e urbanizadas pelo programa Morar Carioca contando com o programa Minha Casa Minha Vida do governo federal, mas com regras específicas, como os gabaritos para cada região.

Muito longe de um consenso, a elaboração do plano diretor, como um dos principais instrumentos de planejamento urbano, refletiu inúmeras discordâncias entre os pontos principais que a prefeitura considerava que deveria constar numa lei que fixa diretrizes que orientarão o crescimento da cidade nas próximas décadas e as pressões que segmentos da sociedade impunham a fim de ludibriar e subestimar as diretrizes do planejamento da cidade. Um dos temas mais polêmicos é o que tratava das emendas propostas para a criação de mais áreas de habitação para as populações de baixa renda próximas às áreas com maior presença de elementos de infraestrutura. $O$ Poder Executivo avaliava que o fracionamento dessas áreas poderia ter um efeito contrário e favorecer o processo de favelização na cidade, pois não se asseguraria o essencial nessas áreas que seriam subaproveitadas e acabariam alvos de invasões.

Dentre várias emendas encaminhadas, poucos dias antes de sua aprovação, estava evidente a intenção de exclusão de clausulas que desburocratizariam a concessão de licenças de projetos a fim de torná-la mais ágil, principalmente pela aproximação dos eventos da Copa e das Olimpíadas e das exigências do "Pacote Olímpico" como, por exemplo, a destinação dos terrenos disponíveis nos chamados núcleos residenciais do Plano Lúcio Costa, que deram origem aos condomínios de vinte andares ou mais na Avenida das Américas, na Barra da Tijuca, onde estão as áreas mais cobiçadas pelo setor hoteleiro para erguer novas unidades e que contarão com a concessão de incentivos fiscais e padrões urbanísticos especiais para a construção de hotéis nessa localidade.

Um dos mecanismos previstos pelo atual plano diretor para garantir 0 aumento da área a ser construída e a alterar o uso do solo é conhecido como outorga onerosa, realizada a partir do pagamento de taxa à prefeitura, e vem sendo incentivado pelo governo nas áreas destinadas aos grandes eventos 
mundiais, como a zona portuária, as áreas dos PEU's de Vargem Grande, o entorno do Estádio Olímpico João Havelange e os corredores de ônibus articulado (BRT) ou Transcarioca (que ligará a Barra da Tijuca ao Aeroporto Internacional), a Transoeste (que ligará Barra a Santa Cruz), a Transolímpica (que ligará a Barra a Deodoro) e a expansão da linha 4 do metro que ligará a zona sul a Barra. Dessa forma a prefeitura almeja arrecadar recursos a fim de garantir os investimentos considerados prioritários para a cidade sediar os eventos.

Muitas regras estabelecidas no atual plano diretor vêm gerando numerosos conflitos de interesses, inclusive acarretando ações judiciais, como no caso dos imóveis tombados, cujos proprietários que mantêm as características originais do prédio recebem o incentivo da isenção do IPTU. No entanto, os críticos do tombamento de imóveis (APA's - Área de Preservação Ambiental e APAC's - Áreas de Preservação do Ambiente Cultural, questionam na justiça a inclusão na política de preservação de imóveis cujos proprietários buscam liberdade para dispor como quiserem de seus imóveis e não simplesmente receberem incentivos para preservá-los.

O plano diretor, por si só, não garante as regras básicas para o planejamento urbano ideal pelo excessivo grau de generalidades que o instrui. Como exemplo: sob o pretexto de moralizar o uso dos espaços públicos da cidade e garantir o convívio social nessas áreas acaba-se promovendo na prática justamente o contrário, deixando brechas para entregar, por concessão, áreas públicas à iniciativa privada. No caso de atividades de longa permanência nos espaços públicos, a prefeitura poderá conceder a área a título precário ou por concessão, mas não fica definido qual o critério para fazer essa escolha. Segundo disposições do Direito Administrativo, trata-se de uma contradição porque a concessão de bens públicos gera direitos. Permissão se dá por ato precário, modificável e revogável unilateralmente pela administração, quando o interesse público 0 exigir. Normalmente, não implicaria indenização, a menos que isso tenha sido pactuado. Já no caso da concessão de uso, se dá por contrato, gerando uma estabilidade e direito para o concessionário. A revogação é mais difícil até na justiça. No caso, as regras do plano diretor deixam brechas para grandes empresas assinarem contratos 
de exclusividade de espaços públicos, atualmente entregues precariamente a pessoas físicas.

Enfim, a elaboração do atual plano diretor esteve envolta em inúmeros conflitos de interesses entre os segmentos da sociedade e de pouco conhecimento e discussão mais ampla pela sociedade. Cada segmento da sociedade encaminhava suas emendas para aprovação na Câmara dos Vereadores sem se chegar a qualquer consenso, de modo apressado, para se cumprir apenas com as obrigações em lei excluindo de todas as formas os princípios democráticos do país. No caso dos parâmetros urbanísticos, foram mantidos os índices estabelecidos pelo plano diretor anterior porque segundo a prefeitura seria mais apropriado abordar o tema nos PEU's - Projetos de Estruturação Urbana, que tratam em detalhes das regras de edificações nos bairros. O equívoco envolveu os IAT - Índices de Aproveitamento de Terreno dos bairros, que definem o seu valor de mercado. No caso de uma área de mil metros quadrados, por exemplo, e o IAT fosse de 1,5, o dono poderia construir até 1,5 mil metros quadrados, respeitando o gabarito. A proposta oficializada na época pela prefeitura e depois rejeitada propunha aumentar o IAT de Santa Tereza, Urca e Paquetá de 1,0 para 1,5; na zona sul (exceto Urca), o IAT, que varia hoje de 3,5 a 4,0 seria padronizado em 2,5. Nesse caso, o proprietário poderia construir conforme regras antigas se pagasse uma taxa ao município (a outorga onerosa). Essa proposta, como outras, revelou total falta de atenção na forma como foram conduzidas as propostas; se fossem reduzidos os parâmetros urbanísticos da zona sul, mas permitida a outorga onerosa, de modo explícito o plano diretor estaria favorecendo a especulação imobiliária e as construtoras repassariam o custo adicional para os preços dos imóveis.

Do modo como foi conduzida a elaboração do atual plano diretor com inúmeras emendas encaminhadas à Comissão de Revisão do plano diretor, Justiça e Redação e Orçamento e Fiscalização Financeira, num curto espaço de tempo, sem uma discussão aberta com a sociedade e na constatação da incapacidade do governo equalizar na prática os interesses dos diversos segmentos da sociedade fez com que o plano diretor se tornasse um repertório de propostas elaboradas unicamente por um viés ideológico nem sempre coerente com a complexa realidade que o envolve e por isso contribuirá pouco de fato no ordenamento territorial no processo de planejamento da cidade do 
futuro. Não nos esqueçamos de que a cidade é uma espacialidade de conflitos e contradições que a modificam permanentemente por razões de diversas naturezas.

A ausência de uma infraestrutura de planejamento nunca impediu que projetos fossem desenvolvidos na cidade. No entanto, os diversos projetos quando implementados se deparam com situações inesperadas e inusitadas, pela própria ausência de um sistema de planejamento e necessário conhecimento das condições locais do ponto de vista físico e estrutural e das situações fundiárias e jurídicas, acabando por gerar aumento de custo pelas desapropriações, indenizações e improvisações a que estão sujeitos.

O ordenamento territorial urbano na metrópole carioca a partir dos anos 90 se insere no contexto de profundas mudanças políticas, jurídicas, administrativas e tributárias legitimadas pela Constituição Federal de 1988, pela importância do papel político do plano diretor, pelos instrumentos urbanísticos dispostos no Estatuto da Cidade, do ideário dos Planos Estratégicos de Cidades, do arcabouço de leis e normas urbanísticas que passaram a influenciar as políticas urbanas elaboradas pelo governo local.

Embora o plano diretor se reafirme como principal instrumento de ordenamento territorial urbano, a sobreposição dos Planos Estratégicos de Cidades resulta num novo rumo de ações e intervenções, à parte de uma estrutura de planejamento que impõe outra lógica de apropriação do espaço urbano direcionada pelas leis de mercado. Os investimentos relacionados aos eventos esportivos se sobrepõem à ordem estabelecida numa construção política e histórica do espaço urbano.

A própria estrutura das relações entre os níveis de governo, o sistema tributário, a valorização do papel político do plano diretor, a forte influência da racionalidade de competitividade entre cidades, a municipalização dos atributos, o desmonte dos órgãos de planejamento substituídos por órgãos de gestão administrativa, o esvaziamento do papel político e de recursos dos Estados federados impedem maiores avanços na perspectiva do desenvolvimento territorial integrado e contribuem para o agravamento dos problemas no Rio de Janeiro e nas demais grandes metrópoles do país. 


\section{CONSIDERAÇÕES FINAIS}

Esta tese teve por intenção contribuir, ao longo do seu desenvolvimento, à preocupação com o fato de que as políticas de ordenamento territorial urbano aplicadas à realidade política, às condições administrativas e ao quadro institucional da metrópole do Rio de Janeiro não se mostraram capazes de transformar ações e intervenções efetivadas em meios de se obter maior funcionalidade do território e bem-estar de seus habitantes. Funcionalidade territorial e melhores condições de vida não são necessariamente alcançadas pelo processo de crescimento econômico, mas ao de desenvolvimento.

A análise do ordenamento territorial como uma evolução técnica, política e científica de atuar sobre o território em busca do desenvolvimento, nos permite aferir no período atual que além da concepção original de ordenar o território segundo recursos dispostos e disponíveis visando à funcionalidade e o bem-estar dos cidadãos a fim de garantir a reprodução das relações capitalistas nos países menos desenvolvidos, há outra percepção do ordenamento territorial que acrescenta à concepção original, outras novas variáveis inclusive indeterminadas na capacidade de arbitrar e conciliar conflitos de interesses que se entrecruzam sobre o território e que precisam ser consideradas.

O ideário de ordenamento territorial no Brasil, sob influências externas, permitiu que ao longo dos anos o país se inserisse no próprio ordenamento econômico mundial a partir dos discursos de: reduzir os desequilíbrios interregionais, de maior funcionalidade territorial e de melhores condições de vida dos habitantes. No entanto, as políticas de ordenamento territorial se deparam com um déficit jurídico, institucional, administrativo e de planejamento que agravam consideravelmente as condições de vida das metrópoles.

A partir dos novos arranjos territoriais e dos novos pactos territoriais, 0 processo de democratização e descentralização de recursos e atributos entre as instâncias do governo desencadeado após a última Constituição Federal, impõe mudanças nas relações verticais e horizontais, assim como indica a necessidade de reforma tributária e fiscal para melhor gerir espaços 
metropolitanos. Estados e municípios encontram-se despreparados e sem apoio político da sociedade para o planejamento integrado.

Por sua vez, os instrumentos urbanísticos encontram-se compartimentados e desconexos de um objetivo comum de ordenamento territorial urbano. O desafio de ordenar regiões metropolitanas impõe reformas jurídicas, institucionais e administrativas, assim como implica numa renovada concepção do planejamento governamental. Faz-se urgente um novo projeto de país, um novo projeto de nação para que o planejamento governamental retome a sua importância para o desenvolvimento do país.

A metrópole do Rio de Janeiro não se mostra capaz de ordenar seu território. Há defasagens políticas importantes a superar a partir de novos arranjos institucionais que conciliem os interesses dos diversos atores em cena no contínuo processo de desenvolvimento territorial. Há necessidade de pensar a médio e longo prazo o desenvolvimento do país. Há uma urgente mudança que implicaria em romper com os limites impostos pelas arraigadas relações de dominação e dependência em vista de maior autonomia das instituições e de toda a sociedade nas decisões. Há necessidade de urgentes reformas na própria constituição político-administrativa do país. Estamos preparados para ordenarmos as forças vivas da sociedade?

A realidade aponta que os governos locais se mostram incapazes de se inserirem numa proposta mais arrojada de ordenamento territorial urbano, necessitando contar com as intervenções do poder central e de outras instituições e organizações nesse processo. As articulações nas relações entre governos, o poder de governança e a capacitação de agentes e instituições numa perspectiva de planejamento a médio e longo prazos são concebidas como premissas básicas do ordenamento territorial urbano.

O ordenamento territorial da metrópole do Rio de Janeiro se depara com um quadro complexo de condições físicas, estruturais, políticas, institucionais e históricas que dificultam maiores avanços na perspectiva de se obter a funcionalidade do território e o bem-estar de seus habitantes. Por outro lado, a sucessão de planos elaborados e mal implementados reforça o papel central da cidade em detrimento da própria realidade das relações sociais constituídas regionalmente. O plano diretor, eleito principal instrumento de planejamento, é desprovido de uma perspectiva regional de desenvolvimento susceptível às 
influências externas no ordenamento de seu território. Diante da dinâmica das relações que se estabelecem territorialmente no mundo globalizado, o plano diretor tornou-se um instrumento ineficaz no ordenamento territorial urbano pelo caráter político hermético assumido que não atende às diretrizes de desenvolvimento da metrópole carioca.

Propõe-se em primeiro lugar combater o crescimento desordenado e 0 disciplinamento a partir do conhecimento amplo do espaço abarcando aspectos naturais, culturais e políticos em diferentes escalas que se interagem de modo que permitam uma percepção do regional, atentando para um aprofundamento nas análises quando baseadas nas estatísticas. Considerando a intensa disputa entre as atividades agrícolas, as cidades e as indústrias, ordenar e disciplinar a ocupação torna-se uma tarefa muito importante. O papel da cartografia é essencial porque permite criar um inventário dos recursos dispostos e disponíveis e consequentemente planificar os usos do solo numa perspectiva dinâmica de atualizações constantes de informações que subsidiariam o ordenamento territorial.

Uma das ideias elaboradas ao longo do trabalho foi de alguma forma apontar certos obstáculos das condições político-administrativas da região em questão, assim como avançar na análise da situação de propriedade das terras e terrenos de extrema importância para o ordenamento territorial. Depois de tantas intervenções urbanísticas e as situações escusas quanto à propriedade, a desordem do processo de expansão urbana e o esgotamento dos recursos naturais; faz-se necessário um suporte destas informações em bases cartográficas de modo que o "inventário" de todas as situações expressa no território se atualize constantemente e subsidie a proposta de ordenamento territorial.

O trabalho buscou enfatizar a importância das condições políticoadministrativas atribuídas à cidade do Rio de Janeiro como Distrito Federal, Estado da Guanabara e atual município e capital do estado do Rio de Janeiro no ordenamento territorial. As intervenções urbanas ao longo desse período reafirmaram a ausência de uma unidade de política urbana, uma estruturação desordenada e socialmente segmentada de pouca articulada com a sua região de influência, incompatibilidades político-partidárias entre governos com 
resultados diretos na descontinuidade das políticas urbanas, ausência de uma percepção metropolitana nas políticas públicas, a incapacidade administrativa de integração, um arcabouço de leis urbanísticas, planos urbanos e órgãos governamentais desconexos e sobrepostos num contexto de grandes influências do governo federal no seu ordenamento territorial.

A estruturação do espaço da Região Metropolitana do Rio de Janeiro caracterizou-se pela fragilidade política, jurídica e administrativa que favoreceu o quadro de superposições de racionalidades diferenciadas ao longo dos anos. Desde o período autoritário do regime de governo que contou com presença de instituições e órgãos do governo federal, em destaque a SERSE, articulados com outros órgãos estaduais, em destaque a FUNDREM, em acordo com programas e planos da prefeitura municipal numa perspectiva de ordenamento territorial no período do regime autoritário até completa desintegração dessa estrutura e a aposta na capacidade do município em impulsionar o desenvolvimento local, regional e nacional, a Região Metropolitana do Rio de Janeiro aguarda por avanços políticos, administrativos e jurídicos direcionados à proposta do ordenamento de seu território visando à funcionalidade territorial e o bem-estar de seus habitantes.

O federalismo brasileiro e as relações estabelecidas entre governos significou o suporte à proposta de ordenamento territorial no trabalho e de certa maneira permitiu desvendar alguns obstáculos. A partir da Constituição Federal de 1988, a relação entre governos reforçou a pulverização de recursos centralizados pela União entre os numerosos municípios e a dependência dessas instâncias dos repasses de recursos do governo federal. Não tendo a intenção de esgotar a análise proposta, o trabalho aponta para maiores investigações como a desproporcionalidade da representação políticopartidária entre os estados brasileiros, principalmente quanto às aprovações orçamentárias que tendem a beneficiar estados de menor índice demográfico em detrimento de estados mais populosos, deixando claro o disparate entre representação política, divisão político administrativa do território brasileiro e as necessárias bases regionais que levariam a uma reformulação dessa representatividade no parlamento. 
Outros obstáculos foram tratados no trabalho que se baseiam no processo estabelecido após a Constituição Federal de 1988 a partir do processo de descentralização de competências entre as instâncias do governo no novo arranjo federativo brasileiro. Constata-se que a ausência de um sistema de planejamento integrado e a maior precisão das competências delegadas às instâncias governamentais são considerados verdadeiros obstáculos à proposta de ordenamento territorial. Os níveis subnacionais de governo se deparam com dificuldades para desempenharem suas funções administrativas e encontram-se despreparados para enfrentar os atuais desafios do ordenamento territorial.

Outra percepção, o trabalho procurou apontar que seria o resgate do papel dos estados federados no ordenamento territorial que foram gradativamente perdendo atribuições e instituições relacionadas ao ordenamento territorial integrado, mesmo apresentando importantes recursos orçamentários e infraestrutura administrativa nessa direção. No entanto, uma suposta reforma tributária do sistema tributário nacional se depara com a impossibilidade de aumentar tributos pela elevada carga tributária do país e por outro lado, o governo federal busca manter o controle da União a partir da concentração de recursos e de seu poder de barganha e patronagem política com estados e municípios, impedindo que essas instâncias alcance sua autonomia tributária e administrativa tão fundamental na proposta de ordenamento territorial.

Diante dos assuntos tratados, o trabalho em si desperta para a fragilidade do papel político do plano diretor, como principal instrumento de planejamento local, principalmente pela ineficiência de sua proposta em controlar o uso e domínio do solo, os recursos hídricos e de acesso aos bens e serviços urbanos e à habitação pelos seus habitantes, e aponta para a sobreposição de planos, leis e normas urbanísticas distantes de uma unidade de política urbana.

Ao final do período das investigações acadêmicas e da troca de numerosas ideias e contatando pessoas relevantes na história do planejamento governamental do país, a realização da entrevista com o ex-ministro do 
planejamento do governo Geisel, o Sr. Reis Veloso contribuiu e subsidiou de forma efetiva, em suas opiniões, informações e críticas elaboradas ao longo do trabalho. Nas suas colocações, o Sr. Reis Velloso deixa claro a importância do planejamento como órgão da Presidência da República no período autoritário no país, da administração pública descentralizada e com flexibilidade e da importância dos órgãos, autarquias, empresas e fundações públicas nesse processo. Aponta para a urgente necessidade de elaborar um projeto de desenvolvimento para o país, assim como do retorno do projeto de desenvolvimento metropolitano e de reformas na administração pública que flexibilize as relações de prestação de serviços e contratos de profissionais especializados em planejamento governamental, de fundamental importância para a qualidade do trabalho desenvolvido pelas instituições como o IBGE e o IPEA para o país.

É necessário que as reflexões científicas se tornem um contínuo aprendizado e subsidie posicionamentos políticos como ações que se complementam e se integram visando sempre à condição humana. Não temos a intenção de esgotar a temática, nem tampouco idealizar práticas de planejamento para o desenvolvimento territorial, mas de certa forma contribuir nas reflexões quanto à realidade que se apresenta identificando pontos e contrapontos no embasamento teórico, no discurso e na prática. 


\section{REFERÊNCIAS}

ABLAS, Luiz. O "Estudo dos Eixos" como instrumento de planejamento regional. In Regiões e Cidades nas regiões: o desafio urbano-regional/org. Maria Flora Gonçalves, Carlos Antônio Brandão, Antônio Carlos Filgueira Galvão. São Paulo: Ed. UNESP: ANPUR, 2003.

ABREU, Silvana de. Planejamento governamental: a SUDECO no espaço mato-grossense: contexto, propósito e contradições. 2001. $328 \mathrm{f}$. Tese (Doutorado em Geografia Humana) - Departamento de Geografia, Universidade de São Paulo, São Paulo, 2001.

ALBUQUERQUE, Roberto Cavalcanti de. Agenda para o planejamento na década dos 90 - SEPLAN/PR. Coletânea SEPES/IPLAN SNP 01/90. Contribuições para reformulação do Sistema Nacional de Planejamento. Brasília, 1990.

ALVES, Alaor Caffé. Planejamento metropolitano e autonomia municipal no direito brasileiro. São Paulo: Bushatsky: Emplasa, 1981.

AMENDOLA, Monica. Uma leitura geográfica dos planos estratégicos da Cidade do Rio de Janeiro. 2002. 216f. Dissertação (Mestrado em Geografia) - Departamento de Geografia, Universidade Federal Fluminense, Niterói, 2002.

ANDRADE, Manuel Correia de. Espaço, Polarização e desenvolvimento:a teoria dos pólos de desenvolvimento e a realidade. Ed. Grijalbo, 1977.

ARAUJO, Fernando Consenza. Ordenamento das finanças públicas e as condições fiscais dos Estados Brasileiros. FGV/EAESP. (2006). Disponível na Internet www.fgv.br. Acesso em 15/08/2009.

AREAL, César A. G.S. O planejamento no Brasil- Processo e Organização-subsídios para a História com ênfase no IPEA. SEPLAN/PR Coletânea SEPES/IPLAN SNP 01/90. Contribuições para reformulação do Sistema Nacional de Planejamento. Brasília, 1990.

BALEEIRO, Aliomar. Direito Tributário Brasileiro. Rio de Janeiro, Ed. Forense, 2000.

BANCO INTERNACIONAL DE RECONSTRUCCION Y FOMENTO. EI Banco Mundial la CFI- Corporación Financeira Internacional y la AIFAsociacíon Internacional de Fomento sus Normas y Operaciones. Washigton, D.C. 1972. 
BANCO MUNDIAL. América Latina y el Caribe : diez años después de la crisis de la deuda. Oficina Regional de América Latina y el Caribe. Washington, D.C, 1993. Urban Policy and Economic Development. An Agenda for the 1990's. A World Bank Policy Paper. Washigton, D.C. 1991.

Banco Internacional para a reconstrução e o desenvolvimento e corporação financeira internacional- Relatório de progresso de estratégia de assistência ao país para 2004-2007- República Federativa do Brasil. 2006. Disponível na Internet www.worldbank.org. Acesso em 20/08/2009.

BARAT, Josef. Política de Desenvolvimento Urbano : Aspectos Metropolitanos e Locais. Série Monográfica. Rio de Janeiro, IPEA/INPES, 1976.

BATISTA JUNIOR, Paulo Nogueira. International financial flows to Brazil since late 1960s. World Bank discussion papers. Library of Congress Cataloging in Publication Data, The World Bank, Washington, D.C. 1987.

BERGAMO, Pedro. Processo de Planejamento Governamental Federal para articulação, negociação e condução institucional. Contribuições para reformulação do Sistema Nacional de planejamento.Coletânea SEPES/IPLAN, Brasília, 1989.

BERNARDES, Lysia Maria Cavalcanti. Rio de Janeiro e sua região. Rio de Janeiro: Secretaria Municipal de Cultura: Departamento Geral de Documentação e Informação Cultural, Rio de Janeiro,1987.

BERNARDES, L.M.C ; MAGALHÃES, V.L. Considerações sobre o Desenvolvimento Regional. Ano 63, No 3, Ed. Vozes, Petrópolis, 1969.

BEZZON, J.C.F. Ação Coordenada para o desenvolvimento Urbano : a institucionalização da Política e do Planejamento Urbano no Brasil na década de 1970. EESC/USP, 2003, 21p. Relatório da disciplina Urbanismo e Planejamento no Brasil Pó-40.

BIELSCHOWSKY, Ricardo (Org.). Cinquenta anos de pensamento na CEPAL- Volumes 1 e 2. Rio de Janeiro : Record, 2000.

BOMFIM, A. N; SHAH, A. Macroeconomic Management and the Division of Powers in Brazil - Perspectives for the Nineties. Working Papers. Country Economics Department, The World Bank, Washigton, 1991.

BOUDEVILLE, Jacques R. Aménagement du territoire et polarisation. Ed. M.TH Génin- Librairies Techniques, 1972. 
BRASIL. Código Tributário Nacional- Lei no 5.172 de 25 de outubro de 1966. Brasília, 1966. Disponível em www.receita.fazenda.gov.br. Acesso em 18/09/2009.

. Constituição (1946). Constituição da República Federativa do Brasil.DF: Senado, 1946. Disponível em www.planalto.gov.br. Acesso em 14/02/2008.

. Constituição (1967). Constituição da República Federativa do Brasil. Brasília, DF: Senado, 1967. Disponível em www.planalto.gov.br. Acesso em 18/01/2008.

. Constituição (1967). Emenda Constitucional No 1, de 17 de outubro de 1969. Decreta recesso do Congresso Nacional e o Poder Executivo fica autorizado a legislar sobre todas as matérias, e dá outras providências. Disponível em: www.planalto.gov.br. Acesso em: 15/03/2009.

. Constituição (1988). Constituição da República Federativa do Brasil. Brasília, DF: Senado, 1988. Disponível em www.planalto.gov.br. Acesso em: 04/07/2008.

. Diretrizes para o desenvolvimento regional, subsídios ao I PND da Nova República. Ministério do Interior. Brasília, 1985.

. Estatuto da Cidade: guia para implementação pelos municípios e cidadãos. 2 ed. Brasília. Câmara dos Deputados, Coord. De Publicações, 2002.

. Ministério da Fazenda. Perfil e Evolução das Finanças Municipais (1998-2007). 2008. Disponível na Internet www.fazenda.gov.br. Acesso em 12/11/2008.

- Ministério da Integração Nacional. Política Nacional de Ordenamento Territorial. 2006. Disponível na Internet www.integração.gov.br. Acesso em 16/08/2009.

. First National Development Plan 1972/74. . Ministério do Interior. II Plano Nacional de Desenvolvimento: programa de ação do governo para a Região Sudeste 1975-1979. Brasília, 1975.

. Ministério do Interior. Diretrizes para o desenvolvimento regional, subsídios ao I PND da Nova República. Brasília, 1985.

. Ministério da Integração Nacional. Para pensar uma política nacional de ordenamento territorial. SDR-Secretaria de Políticas de 
Desenvolvimento Regional. Brasília, 2005. Disponível em www. Mi.gov.br. Acesso em 10/03/2010.

. Ministério da Administração Federal e Reforma do Estado.

Plano Diretor da Reforma do Aparelho do Estado. Brasília, 1995.

. Secretaria de Planejamento. ILPES. Reunião sobre

Planejamento Governamental e a Nova realidade constitucional.

Documentos selecionados sobre planificação em decisões: base jurídica, descentralização e programação. Tomo I e II. Organizado por

SEPES/SEPLAN/PR. Brasília, 1989.

. Ministério do Planejamento, Orçamento e Gestão. Plano

Plurianual 2004-2007: pactos para a gestão territorial integrada. Texto para discussão. Brasília: MP, 2005.

Ministério do Planejamento, Orçamento e Gestão. Estudo da

dimensão territorial do PPA. Secretaria de Planejamento e Investimentos Estratégicos e Centro de Gestão e Estudos Estratégicos. Brasília:

SPI/MP,2006.

. Plano Diretor da Reforma do Aparelho do Estado.

Presidência da República, Câmara da Reforma do Estado, Ministério da Administração Federal e Reforma do Estado. Brasília, 1995.

SERSE-Secretaria Especial da Região Sudeste.

Programas e atividades/Ministério do Interior, 1983.

Lei Complementar No 101 de 04 de maio de 2000.

Estabelece normas de finanças públicas voltadas para a responsabilidade na gestão fiscal. Disponível na Internet www.tesouro.fazenda.gov.br. Acesso em 22/06/2010.

NATIONAL DEVELOPEMENT PLAN, 1972/74.

. PLANO DIRETOR DA REFORMA DO APARELHO DO

ESTADO. Presidência da República, Câmara da Reforma do Estado, Ministério da Administração Federal e Reforma do Estado, 1995.

.PLANO NACIONAL DE ORDENAMENTO TERRITORIAL.

Disponível na internet www.integração.gov.br. Acesso em em 12/03/2009.

PLANO NACIONAL DE DESENVOLVIMENTO URBANO.

Disponível na internet www.integração.gov.br. Acesso em 17/03/2009. 
BRASILEIRO, Ana Maria. Região Metropolitana do Grande Rio: serviços de interesse comum. Centro de Pesquisas Urbanas do IBAM/IPEA, 1976, Brasília.

Brasília, DF, IPEA/IPLA, 1979.

A fusão: análise de uma política pública.

CAFFÉ, Alaor Alves. Planejamento Metropolitano e autonomia municipal no direito brasileiro. São Paulo: Bushatsky, Emplasa, 1981.

CASTRO, Therezinha de. Notas sobre a Cidade do Rio de Janeiro. In Geografia e Geopolítica- A contribuição de Delgado de Carvalho e Therezinha de Castro. Rio de Janeiro: IBGE, 2009.

CEPAL/ILPES. Planificación regional y urbana em América Latina. Seminario sobre Planificación Regional y Urbana en América Latina. México: Siglo Veintiuno, 1974.

CHEIN, Flávia Lúcia Feres. Planejamento governamental e política regional: o Brasil frente ao novo paradigma. Dissertação. EAESP/FGV, 2001.349p.

CINTRA, Antônio Octávio, HADDAD, Paulo Roberto. Dilemas do Planejamento Urbano e Regional no Brasil. Ed. Zahar, 1978.

COSTA, Jorge Gustavo da Costa. Planejamento Governamental. A Experiência Brasileira. FGV, Rio de Janeiro-GB, 1971.

COUTO E SILVA, Golbery do. Geopolítica do Brasil. Ed. José Olympio, Rio de Janeiro,1967.

DALLARI, Adilson Abreu; FERRAZ, Sérgio (Coord). Estatuto da Cidade (Comentários à Lei Federal 10.257/2001). São Paulo, Ed. Mallheiros, 2006.

D'ARAUJO, Maria Celina e CASTRO, Celso. Ernesto Geisel. Rio de Janeiro: Ed. FGV, 1997.

*DESENVOLVIMENTO REGIONAL E ESTRUTURAÇÃO DA REDE URBANA. IPEA, IBGE, UNICAMP/IE/NESUR, Brasília: IPEA, 2001.

DINIZ, Eli. Crise, reforma do Estado e governabilidade. São Paulo: Editora FGV, 1997.

DREIFUSS, René Armand. 1964: a conquista do Estado-Ação Política, Poder e Golpe de Classe.Ed. Vozes, Petrópolis, 1981. 
EVANGELISTA, Helio de Araujo. A fusão dos estados da Guanabara e do Rio de Janeiro. Rio de Janeiro: Arquivo Público do Estado do Rio de Janeiro, 1998.

ESTADO DO RIO DE JANEIRO. Constituição do Estado do Rio de Janeiro. Rio de Janeiro, RJ: Assembleia Legislativa, 1989. Disponível em www.aleri.ri.gov.br. Acesso em 21/09/2009.

Código Tributário do Estado do Rio de Janeiro- DecretoLei No 05 de 15 de março de 1975. Rio de Janeiro, RJ: Secretaria de Fazenda, 1975. Disponível em: www.fazenda.ri.gov.br. Acesso em: 21/09/2009.

ESCOLA SUPERIOR DE GUERRA. Avaliação da conjuntura. Centro de Atividades Externas da Escola Superior de Guerra. 2006. Disponível na Internet www.esg.br. Arquivo consultado em 25/08/2009.

ESTIENNE, Gustavo. A reconstrução do Rio de Janeiro - A questão do Patrimônio Municipal, Rio de Janeiro: Typ do Jornal do Comércio, de Rodrigues \&C., 1904.

FARAH, Marta Ferreira Santos. Gestão pública local, novos arranjos institucionais e articulação urbano-regional. Regiões e Cidade, Cidades nas regiões: o desafio urbano-regional/org. Maria Flora Gonçalves, Carlos Antônio Brandão, Antônio Carlos Filgueira Galvão. São Paulo: Ed: UNESP: ANPUR, 2003.

FELDMAN, Sarah. Política urbana e regional em cidades nãometropolitanas. In Regiões e Cidades, cidades nas regiões - $O$ Desafio urbano - regional. São Paulo: Ed: UNESP: ANPUR, 2003.

FRANÇA. Commissariat Generale du Plan. Rapport du Comité Aménagement du Territoire. La documentation française. 1980.

FREIRE, Américo, SARMENTO, Carlos Eduardo e MOTTA, Marly Silva da. Um estado em questão: os 25 anos do Rio de Janeiro. Rio de Janeiro, Ed. FGV, 2001.

GALVÃO, Antônio Carlos Filgueira. Novos elementos para repensar o Planejamento Regional. Diagnóstico, Indicadores e Cenários para a Ação Governamental e Políticas Públicas. IPEA, 1995.

Gestão do uso do solo e disfunções do crescimento urbano: instrumentos de planejamento e gestão urbana: Brasília e Rio de Janeiro/IPEA, USP, UnB, UFRJ. Brasília: IPEA, 2001. 
GARCIA, R.C. A Reorganização do Processo de Planejamento do Governo Federal: O PPA 2000-2003. Texto para Discussão. Brasília, No 726, p 5-41, Mai/2000. Disponível em www.ipea.gov.br. Acesso em: 28/09/2009.

GARDIN, Cleonice. A Comissão Interestadual da Bacia ParanáUruguai no planejamento regional brasileiro (1951-1972). Dourados-MS, Ed. Da UFGD, 2009.

GIUBERTI, Ana Carolina. Efeitos da Lei de Responsabilidade Fiscal sobre os gastos dos municípios brasileiros. FEA/USP- PPGE, São Paulo, 2005. Disponível em www.usp.br/dissertações. Aceso em: 19/08/2009.

GOHN, Maria da Glória. Teoria dos Movimentos SociaisParadigmas clássicos e contemporâneos. São Paulo, Ed. Loyola, 1997.

GONDIM, Linda Maria de Pontes. Planners in the face of power, The case of the metropolitan region of Rio de Janeiro, Latin American Studies Program, Dissertation Series, Cornell University, Brazil, 1986.

GONÇALVES, Rafael Soares. Les favelas de Rio de Janeiro: histoire d droit XIXe - Xxe siècles. Paris, L'Harmattan, 2010.

GONÇALVES, Maria Flora, BRANDÃO, Carlos Antônio, GALVÃO, Antônio Carlos(Org). Regiões e Cidades, Cidades nas Regiões: $O$ desafio urbano-regional. São Paulo: ANPUR. Ed. Unesp, 2003.

GRAU, Eros Roberto. Regiões Metropolitanas- Regime Jurídico. São Paulo, Ed. Bushatsky, 1974.

GUIMARÃES, Nathália Arruda Guimarães. Os municípios e o Estatuto da Cidade. Rio de Janeiro, Ed. Temas e Ideias, 2004.

GUIMARÃES, Paulo César Vaz. Um estudo sobre o Banco Mundial e o desenvolvimento municipal. São Paulo, EAESP/FGV, 1993.

HADDAD, Paulo Roberto. O que fazer com o planejamento regional no Brasil da próxima década? Ed. Face: CEDEPLAR, 1989 e SCHWARTZMAN, Jacques. Teoria dos pólos de desenvolvimento: um estudo de caso. Belo Horizonte: CEDEPLAR, 1972.

HAESBAERT, Rogério. 0 mito da desterritorialização: do "fim dos territórios" à multiterritorialidade. Rio de Janeiro: Bertrand Brasil, 2004.

HOUÉE, Paul. Um éveilleur d'humanité -Louis Joseph Lebret. Paris: Les Éditions de l'Atelier/Éditions Ouvrières, 1997. 
IANNI, Octavio. Estado e Planejamento Econômico no Brasil. Ed. Civilização Brasileira S.A. Rio de Janeiro, 1986.

IBGE - Instituto Brasileiro de Geografia e Estatística/CNG - Conselho Nacional de Geografia. Guia de excursão pelo Estado da Guanabara. Biblioteca Geográfica Brasileira, Divisão de Geografia, Publicação No 19, Rio de Janeiro, 1965.

ILPES- Instituto Latinoamericano y Del Caribe de Planificacion Econômica y Social. Planejamento Governamental e a Nova realidade constitucional.SEPES/SEPLAN/PR, Brasília, 1989.

IPEA- Instituto de Pesquisa Econômica Aplicada. Estado, Instituições e Democracia: república. Projeto Perspectivas do Desenvolvimento Brasileiro. IPEA, Livro 9, v1, Brasília, 2010. Disponível em www.ipea.gov.br. Acesso em: 09/03/2010.

KERCHES, Cristiane. O processo de Ordenamento fiscal no Brasil na década de 1990 e a Lei de Responsabilidade Fiscal. USP/FFLCHDepartamento de Ciência Política, São Paulo,2005. Disponível em: www.usp.br/dissertações. Acesso em 03/10/2009.

LABASSE, Jean. La Organização Del Espacio: elementos de geografia aplicada. Instituto de Estudios de Administración Local, 1960.

LACOSTE, Y. De La géopolitique aux paysages-Dictionnaire de La géographie, Armand Colin, 2003.

LAVINAS, Lena; MAGINA, M.A. Federalismo e Desenvolvimento Regional: Debates da Revisão Constitucional. Texto para discussão. Rio de Jajneiro, IPEA, No 390, p. 1-30, Nov.1995. Disponível em www.ipea.gov.br. Acesso em 02/06/2010.

LE, Yoon Joo. The spatial structure of metropolitan regions of Brazil. World Bank Discussion papers. Library of Congress Cataloging in Publication Data, The World Bank, Washington, D.C.1987.

LEBRET, J.L. Guide Pratique dé'enquête sociale. IV. L'enquête en vue de l'aménagement regional. Presses Universitaires de France. Paris, 1958.

Guide Pratique de L'enquête sociale. I Manuel de

l'enquêteur. Presses Universitaires de France. Paris, 1952. 
Suicide ou Survie de L'Occident? Dossier pour comprende lês problèmes de CE temps. Presses Universitaires de France, Paris, 1956.

Dynamique concrète du développement. Presses Universitaires de France, Paris, 1961.

LESSA, Carlos. O Rio de todos os brasis. Rio de Janeiro: Record, 2000.

LOPREATO, Francisco Luiz Cazeiro. 0 colapso das finanças estaduais e a crise da federação/Francisco Luiz Cazeiro Lopreato. São Paulo: Ed. UNESP. IE-Unicamp, 2002.

MACHADO, Denise Barcellos Pinheiro, PEREIRA,Margareth da Silva e SILVA, Rachel Coutinho Marques da. Urbanismo em questão. Rio de Janeiro: UFRJ/PROURB, 2003.

MARTONE, C.L. Macroeconomic Policies, Debt Accumulation, and Adjustment in Brazil, 1965-84. World Bank Discussion papers. Library of Congress Cataloging in Publication Data. The World Bank, Washington, D.C, 1987.

Fiscal Policy and Stabilization in Brazil. Working Papers.

World Development Report, The World Bank, Washington, D.C, 1989.

MATUS, Carlos R. Adeus, senhor presidente: governantes governados. São Paulo: FUNDAP, 1996.

MEIRELES, Hely Lopes. Direito Municipal Brasileiro. Ed. Malheiros 14a d. São Paulo, 2006.

MINISTÉRIO DO INTERIOR-Secretaria Geral. II Plano Nacional de Desenvolvimento: programa de ação do governo para a Região Sudeste 1975-1979, Brasília, 1975.

.II Plano Nacional

de Desenvolvimento. Programa de Ação do Governo na Área do Desenvolvimento Urbano- 1975/79. Brasília, 1975.

Secretaria

Especial da Região Sudeste. SERSE- Atividades e Programas. Rio de Janeiro-SERSE, 1983. 
SERFHAU.

Planejamento Metropolitano. Anais do II Curso de Planejamento Urbano e Local- Serfhau, Gegran, Cogep, OEA.

Diretrizes para o

desenvolvimento regional, subsídios ao I PND da Nova República.

Brasília, 1985.

MINISTÉRIO DO PLANEJAMENTO E COORDENAÇÃO ECONÔMICA - Plano Decenal de Desenvolvimento Econômico e Social. Tomo VII, versão preliminar, Desenvolvimento Urbano no Brasil - I Aspectos significativos do Processo de Urbanização. Março, 1967.

MONOD, Jérôme d CASTELBAJAC, Philippe de. L'Aménagement du Territoire, Ed. PUF, 2010.

MOTA, Marly S. A fusão da Guanabara com o Estado do Rio de Janeiro: desafios e desencontros. In. (Coord) FREIRE, Américo etti d. Um Estado em Questão: os 25 anos do RJ. Rio de Janeiro, Ed. FGV, 2001. , SARMENTO, Carlos Eduardo. A construção de um estado: a fusão em debate. Rio de Janeiro: Ed. FGV, 2001.

MONTE-MOR, Roberto Luís M. A questão urbana e o Planejamento Urbano- Regional no Brasil Contemporâneo. 2004. Disponível na Internet www.cedeplar.ufmg.br. Arquivo consultado em 11/09/2009.

MORA, Mônica. Federalismo e dívida. Texto para discussão. Rio de Janeiro, IPEA, No 866, p. 1-90, Mar.2002. Disponível em www.ipea.gov.br. Acesso em: 25/08/2009.

NASCIMENTO, Edson Ronaldo. Lei Complementar No 101/2000: entendendo a Lei de Responsabilidade Fiscal/llvo Debus. Brasília: ESAF, 2002.

PARISI, Licio. Modo de producción y metropolización en América Latina (I). ILDIS- Instituto LatinoAmericano de Investigaciones Sociales. Santiago de Chile, 1972.

PELLETIER, Denis. Economie et Humanisme - De l'utopie communautaire au combat pour le tiers-monde (1941-1966). Paris, Les éditions du Cerf, 1996.

PEREIRA, Luiz Carlos Bresser. A reforma do aparelho do Estado e a Constituição Brasileira. MARE-(Ministério da Administração Federal e Reforma do Estado)/ENAP, 1995. 
PERRIN, J.C. Le développement regional. Paris: Presses Universitaire de France, 1974.

PERROUX, François. Consideraciones en torno a la nocion de polo de crecimiento. In Cuadernos de la Sociedad Venezolana de Planificación, ILPES/CEPAL, Caracas, v.II, No 3-4, p. 1-15 1963.

PIANCASTELLI, M; CAMILLO, R. Redistribuição do Gasto Público em democracias federativas: análise do caso brasileiro. Texto para discussão. Brasília, IPEA, No 1001, Nov.2003. Disponível em www.ipea.gov.br. Acesso em: 14/02/2010.

POGGIESE, Héctor Atilio. Política urbana e participação popular na Região Metropolitna do Rio de Janeiro (1975-1982). Monografia de Mestrado em Administração Pública, FGV, 1985, EBAP, p. 319.

POLETTO, Cleide, A exploração de pedreiras na Região Metropolitana de São Paulo no contexto do planejamento e gestão do território. 2006. 236f. Tese - Departamento de Geografia, Universidade de São Paulo, São Paulo, 2006.

PREFEITURA DA CIDADE DO RIO DE JANEIRO. Plano Diretor Decenal de 1992: déia os para sua revisão. IPP/SMU,2005.Disponível na Internet www.armazemdedados.ri.gov.br. Arquivo consultado em 11/10/2009.

Plano Estratégico da Cidade do Rio de Janeiro- Rio Sempre Rio. Imprensa da Cidade, Rio de Janeiro,1996.

\section{Estudos para} integração de políticas públicas na Região Metropolitana do Rio de Janeiro. IPLANRIO, Rio de Janeiro, 1994.

Desenvolvimento Institucional e Gestão do Espaço Metropolitano do Rio de Janeiro alternativas e propostas. IplanRio, Rio de Janeiro, maio, 1995. . Lei Orgânica do Município do Rio de Janeiro. Disponível em www2.rio.rj.gov.br. Acesso em 11/05/2009.

RIBEIRO, Ana Clara Torres e SILVA, Cátia Antônia da. Tendências da metropolização brasileira: ação e déia os . In Revista da Região Metropolitana do Rio de Janeiro- Rio Urbano 2: o crescente papel da "periferia" do "centro" ano... 
ROCHEFORT, Michel. O problema da regionalização no Brasil. Ministério do Planejamento e Coordenação Geral/IPEA, 1969 No 145.

RAFFESTIN, Claude. Por uma geografia do poder. São Paulo, Ed. Ática, 1993.

ROLNIK, Raquel e SOMEKH, Nádia. Governar as metrópoles: dilemas da recentralização. In Regiões e Cidades, Cidades nas regiões: $O$ desafio urbano-regional. São Paulo. Ed: UNESP: ANPUR, 2003.

SÁ, Luis. Razões do Poder Local, Finanças Locais, Adensamento do Território, Regionalização. Caminho Poder Local, Lisboa, 1991.

SANTOS, Milton. A Natureza do espaço: espaço e tempo: razão e emoção. São Paulo: Hucitec, 1999.

SANTOS JUNIOR, Orlando Alves dos. O Fórum Nacional de Reforma Urbana: incidência e exigibilidade pelo direito à cidade. Rio de Janeiro: FASE, 2009.

SHAH, Anwar. The new fiscal déia os in Brazil. World Bank discussion papers. Library of Congress Cataloging in Plubication Data, The World Bank, Washington, D.C. 1991.

SCHLEE, Mônica Bahia; TÂNGARI, Vera Regina. As montanhas e suas águas: a paisagem carioca na legislação municipal (1937 -2007). Cadernos Metrópole, Rio de Janeiro, n19, p 271-291, 1ํsem. 2008. Disponível em: Acesso em 05/11/2010.

SECRETARIA DE ECONOMIA E PLANEJAMENTO DO ESTADO DE SÃO PAULO- Áreas Metropolitanas. Artigo: Aspectos Institucionais das Áreas Metropolitanas (texto de conferência proferida no Seminário Internacional sobre Planejamento Metropolitano, promovida pela OEA- In Anais do II Curso de planejamento Urbano e Local, d. Do SERFHAU, Guanabara. In GEGRAN. São Paulo, 1972.

SILVA, Golbery do Couto. Geopolítica do Brasil. Rio de Janeiro, Ed. José Olympio, 1967.

SILVEIRA, R; MALPEZZI, S. Welfare Analysis of Rent Control in BrazilThe case of Rio de Janeiro. Discussion Paper. Infrastructure and Urban Development Department, The World Bank, Washington, D.C. 1991.

SKIDMORE, Thomas E. Brasil: de Getúlio Vargas a Castelo Branco (1930-1964). Rio de Janeiro-GB: Paz e Terra, 1976.

1985). Rio de Janeiro: Paz e Terra, 1988.

Brasil: de Castelo a Tancredo, (1964- 
SOARES, Ricardo Pereira. Dívida Publica Externa: Empréstimos do BIRD ao Brasil. Texto para discussão No 642. IPEA. Brasília, maio de 1999.

SUBRA, Philippe. Géopolitique de L'Aménagement du Territoire. Paris, Ed. Armand Colin, 2007.

SMITH, Neil. Desenvolvimento Desigual- Natureza, Capital e a Produção do Espaço. Rio de Janeiro: Ed. Bertrand,1988.

TAVARES, Maria da Conceição- Reflexões sobre o estado e o planejamento. UFRJ/IEI, Rio de Janeiro, 1987.

SOUZA, Marcelo Lopes de. A prisão e a ágora: reflexões em torno da democratização do planejamento e da gestão das cidades. Rio de Janeiro: Bertrand Brasil, 2006.

VALLADARES, Licia do Prado. A invenção da favela - Do mito de origem a favela.com. Rio de Janeiro: Editora FGV, 2005.

VARSANO, Ricardo. A evolução do sistema tributário brasileiro ao longo do século: anotações e reflexões para futuras reformas. Texto para discussão. Rio de Janeiro, IPEA, No 405, p. 1-34,Jan.1996. Disponível em www.ipea.gov.br. Acesso em 01/09/2010.

VÁZQUEZ-BARQUERO A. Desarrolo local. Uma estratégia de creación de empleo, Editorial Pirámide, Madrid, 1998.

Política déia os local. La respuesta de lãs ciudades a los déia os Del ajuste productivo. Editorial Pirámide, Madrid, 1993.

Crescimiento endógeno o desarrolo endógeno?, em Cuadernos Del Claeh, No 78-79, Montevideo, 1997.

VIEIRA, José Ribas. Introdução à teoria do estado. Porto Alegre: Síntese, 1999.

VILLAÇA, Flávio. Dilemas do Plano Diretor. In: CEPAM. O município no século XXI: cenários e perspectivas. São Paulo: Fundação Prefeito Faria Lima- CEPAM, 1999.

XAVIER, Rafael. O município no Brasil. In O IBGE na história do municipalismo e sua atuação nos municípios: o pensamento de Teixeira de Freitas e de Rafael Xavier/IBGE, CDDI- Rio de Janeiro: IBGE, 2008.

WIRTH, Louis. El urbanismo como modo de vida. Buenos Aires, Ed. Paidós, 1962. 


\section{RELATÓRIOS}

ALVES, J.V; REIS, J.C. Tomada de contas da Secretaria Especial da Região Sudeste - SERSE do exercício de 1987. Brasília: MINTER/CISET, 1988. 8fls. Relatório de Auditoria- Processo No 10768.008003/88-14.

DAIN, I; PORTO, F.N.M. Tomada de contas da Secretaria Especial da Região Sudeste - SERSE do exercício de 1983. Rio de Janeiro: SERSE, 1984,9fls. Relatório de Auditoria - Processo No 02.0235/84/SEPLAN/PR/RJ.

FREIRE, A. Um painel do campo político carioca. Rio de Janeiro: Rio Estudos, 2002, No 80. Disponível em www.armazemdedados.rio.ri.gov.br. Acesso em 12/03/2009.

HOLANDA, A.N.C. Aspectos Políticos e Econômicos das Receitas e dos Gastos Públicos no Brasil. Rio de Janeiro, IPEA, 1993. Texto para Discussão No. 297. Disponível em WWW.ipea.gov.br.

LEMOS, M.B. Diretrizes para Formulação de Políticas de Desenvolvimento Regional e de Ordenação do Território Brasileiro. Belo Horizonte: SPDR: M.I, 2004, 29f. Relatório Regionalização: Análise da Experiência Brasileira Recente, CEDEPLAR. Disponível em www.mi.gov.br . Acesso em 29/03/2009.

MONTE-MOR, R.L. Diretrizes para Formulação de Políticas de Desenvolvimento Regional e de Ordenação do Território Brasileiro. Belo Horizonte: SPDR: MI, 2004, 20p. Relatório A questão Urbana e o Planejamento Urbano e Regional no Brasil Contemporâneo, CEDEPLAR. Disponível em: www.mi.gov.br. Acesso em 07/05/2009.

OLIVEIRA, J.C; LIMA, Z.M.S. Tomada de contas da Secretaria Especial da Região Sudeste - SERSE do exercício de 1980. Brasília: MINTER/SCI, 1981, 14fls. Certificado de Auditoria. Processo No 00-81-014139 - MINTER.

SILVA, F. Tomada de contas da Representação do Ministério do Interior no Rio de Janeiro - REMI do exercício de 1978. Brasília: MINTER/REMI, 1979, 7fls. Certificado de auditoria. Processo No 063/REMI/RJ/79.

SILVA, M.E; SILVA, M e DAIN, I. Tomada de contas conjuntas da unidade gestora Secretaria Especial da Região Sudeste do exercício de 1982. Rio de Janeiro: MINTER/SCI, 1983, 11fls. Relatório 00048. Processo No SEPLAN/PR/No 181/83-RJ. 
VARSANO, R. A evolução do sistema tributário brasileiro ao longo do século: anotações e reflexões para futuras reformas. Pesquisa Planejamento Econômico. Rio de Janeiro, V.27, n.1, Abr,1997. Disponível em www..ipea.gov.br.

\section{ARTIGOS EM REVISTAS}

BAER, W.;GEIGER,P.P. Industrialização, urbanização e a persistência das desigualdades regionais do Brasil. Revista Brasileira de Geografia, Rio de Janeiro, n2, p. 3-99, Abr/Jun, 1976. Disponível em: www.biblioteca.ibge.gov.br. Acesso em 11/10/2009.

BECKER, B.; BERNARDES, N. Considerações sobre o desenvolvimento regional e a localização espacial das atividades em países em desenvolvimento. Revista Brasileira de Geografia, Rio de Janeiro, n3, p.135150, 1979. Disponível em: www.biblioteca.ibge.gov.br. Acesso em 11/10/2009.

BERNARDES, L.M. Importância da posição como fator do desenvolvimento do Rio de Janeiro. Aspectos da Geografia Carioca, Rio de Janeiro, v9, p.3-17,1962.

BERNARDES, L. M.C. Expansão do espaço urbano no Rio de Janeiro. Revista Brasileira de Geografia, Rio de Janeiro, n3, p. 495-526, Jul/Set, 1961. Disponível em: www.biblioteca.ibge.gov.br. Acesso em 26/02/2009.

BERNARDES, L.M.C. Geografia e Poder Nacional. Revista Brasileira de Geografia, Rio de Janeiro, n3, p. 267-281, Jul/Set, 1966. Disponível em: www.biblioteca.ibge.gov.br. Acesso em 18/05/2009.

BERNARDES, L.M. Considerações sobre a região do Rio de Janeiro. Revista Brasileira de Geografia, Rio de Janeiro, n4, p. 99-108, Out/Dez, 1971. Disponível em: www.biblioteca.ibge.gov.br. Acesso em 25/08/2009.

BECKER, B. Expansão do mercado urbano e transformação da economia pastoril. Revista Brasileira de Geografia, Rio de Janeiro, n4, p.207328, Out/Dez, 1966. Disponível em: www.biblioteca.ibge.gov.br. Acesso em 18/05/2009.

BOISIER, Sérgio. «Política económica, organização social y desarrolo regional », Cuadernos del ILPES No 29, 5a edición, Santiago de Chile, 1991. 
«Desarrolo regional endógeno en Chile. Utopia o necessidad?, en Ambiente y Desarrollo, Vol. IX-2, CIPMA, Santiago de Chile,1993.

«El vuelo de una cometa. Una metáfora para una teoría del desarrolo territorial », en Revista Eure, No 69, P.U.C/I.E.U, Santiago de Chile,1997.

«Post-scriptum sobre desarrolo regional : modelo reales y modelos mentales ", en Anales de Geografia de la Universidad Complutense, No 18, Madrid, 1998.

«El desarrolo territorial a partir de la construcción de capital sinergético » en Estudios Sociales, No 99, C.P.U., Santiago de Chile, 1999.

Em busca do esquivo desenvolvimento regional: entre a caixa preta e o projeto político, 1996. . Ensayo sobre descentralización e desenrollo regional. Cuadernos do Ilpes. Santiago, Chile. Ano.

BREMAECKER, François E. J. Efeitos da proposta de Reforma Tributária nas finanças municipais. Série Estudos Especiais No 51. IBAM/IBAMCO.Rio de Janeiro, 2003. Disponível na Internet www.ibam.org. Arquivo consultado em 04/08/2009.

CASTRO, T. Evolução Política e Crescimento da Cidade do Rio de Janeiro. Revista Brasileira de Geografia, Rio de Janeiro, n4, p.569-588, Out/Dez,1965. Disponível em: www.biblioteca.ibge.gov.br. Acesso em 11/05/2009.

COMIM, Alvaro A. e FREIRE, Carlos Torres. Além do ambiente de investimentos: por que as relações entre atores públicos e privados importam para o desenvolvimento. 07/2008. Disponível em: www.cebrap.org.br. Acesso em 08/03/2009.

CORREA, R.L. Os estudos de redes urbanas no Brasil. Revista Brasileira de Geografia, Rio de Janeiro, n4, p. 93-116, Out/Dez, 1967. Disponível em: www.biblioteca.ibge.gov.br. Acesso em 13/06/2009.

CORREA, R. L.; Contribuição ao estudo do papel dirigente das metrópoles brasileiras. Revista Brasileira de Geografia, Rio de Janeiro, n2, p. 56-87, Abri/Jun, 1968. Disponível em: www.biblioteca.ibge.gov.br. Acesso em 13/06/2009.

CROCCO, Marco,G. Frederico e Jr. Jayme. Diretrizes para formulação de políticas de Desenvolvimento Regional e de Ordenação do território 
brasileiro - Relatório de Avaliação das condições de financiamento de políticas regionais. FACE/CEDEPLAR-UFMG. (2005). Disponível na página www.integração.gov.br. Acesso em 23/11/2008.

DINIZ, Eli. Governabilidade, governança e reforma do Estado: considerações sobre o novo paradigma. Revista do Serviço Público. Brasília: ENAP, 1996.

DINIZ, Clélio Campolina. Desenvolvimento Poligonal no Brasil: nem desconcentração, nem contínua polarização. Revista Nova Economia, Vol 3 N.1. Belo Horizonte, CEDEPLAR, 1993.

e perspectivas. FUNDAP, 1995. Sudeste: heterogeneidade estrutural

DOMINGUES, A.J.P. O planejamento geográfico e a participação do CNG. Revista Brasileira de Geografia, Rio de Janeiro, n2, p.217-220, Abr/Jun, 1964. Disponível em: www.biblioteca.ibge.gov.br. Acesso em 06/11/2009.

DUARTE, H.S.B. A cidade do Rio de Janeiro: descentralização das Atividades Terciárias - os centros funcionais. Revista Brasileira de Geografia, Rio de Janeiro, n1, p. 53-98, Jan/Mar, 1974. Disponível em: www.biblioteca.ibge.gov.br. Acesso em 06/09/2009.

FAISSOL, S. A Estrutura Urbana Brasileira: Uma visão do Processo Brasileiro de Desenvolvimento Econômico. Revista Brasileira de Geografia, Rio de Janeiro, n3, p. 19-123, Jun/Set, 1972. Disponível em: www.biblioteca.ibge.gov.br. Acesso em 25/08/2009.

FAISSOL, S. A organização espacial do Sistema Urbano Brasileiro: relações entre a estrutura das cidades e as relações entre elas. Revista Brasileira de Geografia, Rio de Janeiro, n3, p. 75-90, Jun/Set, 1974. Disponível em: www.biblioteca.ibge.gov.br. Acesso em 06/09/2009.

FOLHA DE SÃO PAULO. Lebret, precursor do Grande São Paulo, Grande São Paulo: o desafio do ano 2000. Suplemento Especial, Setembro/Outubro de 1967.

FREIRE, Américo, SARMENTO, Carlos Eduardo e MOTTA, Marly Silva da. Um painel do campo político carioca- Três faces da cidade: um estudo sobre a institucionalização e a dinâmica do campo político carioca (18891969), 2002. Disponível na página www.armazémdedados.ri.gov.br. Arquivo consultado em 11/11/2009.

FREIRE, A. Três faces da cidade: um estudo sobre a institucionalização e a dinâmica do campo político carioca (1889-1969). 
Coleção Estudos da Cidade. Rio de Janeiro, Rio Estudos, No 80, p. 1 22,Nov.2002. Disponível em: www.armazemdedados.rio.ri.gov.br. Acesso em $11 / 04 / 2009$.

GALVÃO, M.V., FAISSOL, S., LIMA, O.M.B; ALMEIDA, J.M. Áreas de pesquisa para determinação de áreas metropolitanas. Revista brasileira de geografia, Rio de Janeiro, n4, p. 53-128, Out/Dez, 1969. Disponível em: www.biblioteca.ibge.gov.br. Acesso em 22/07/2009.

GEIGER, P.P. Ensaio para a estrutura urbana do Rio de Janeiro. Revista Brasileira de Geografia, Rio de Janeiro, n1, p. 3 46, Jan/Mar, 1960. Disponível em: www.biblioteca.ibge.gov.br. Acesso em 22/09/2009.

GEIGER, P.P. e DAVIDOVICH, F. Aspectos do fato urbano no Brasil. Revista Brasileira de Geografia, Rio de Janeiro, n2, p.263-362, Abr/Jun, 1961. Disponível em: www.biblioteca.ibge.gov.br. Acesso em 18/09/2009.

GEIGER, Pedro Pinchas. Geografia e Planejamento. Revista Brasileira de Geografia, Rio de Janeiro, n3, p. 111-118, Jul/Set, 1967. Disponível em: www.biblioteca.ibge.gov.br. Acesso em 13/06/2009.

GEIGER, P.P. Regionalização. Revista Brasileira de Geografia, Rio de Janeiro, n1, p.5-25, Jan/Mar, 1969. Disponível em: www.biblioteca.ibge.gov.br. Acesso em 21/07/2009.

GEIGER, P.P. Divisão regional e problema regional. Revista Brasileira de Geografia, Rio de Janeiro, n2, p. 157-170, Abr/Jun, 1970. Disponível em: www.biblioteca.ibge.gov.br. Acesso em 22/07/2009.

GEIGER, P.P.DAVIDOVICH, F.R. Reflexões sobre a evolução da estrutura espacial do Brasil sob o efeito da industrialização. Revista Brasileira de Geografia, Rio de Janeiro, n3, p.3-29, Jun/Set, 1974. Disponível em: www.biblioteca.ibge.gov.br. Acesso em 06/09/2009.

GUIMARÃES, F.M.S. O planalto central e o problema da mudança da capital do Brasil. Revista Brasileira de Geografia, Rio de Janeiro, n4, p. 471542 , Out/Dez,1949. Disponível em: www.biblioteca.ibge.gov.br. Acesso em 12/06/2009.

KORNIN, Thaís e MOURA, Rosa. Metropolização e Governança urbana: relações transescalares em oposição a práticas municipalistas. Revista Geousp-Espaço e Tempo, São Paulo, No 16, 2004. Disponível na Internet www.geografia.fflch.usp. Acesso em 06/07/2009.

LAVALLE, A. G; CASTELO, G;BICHIR, R.M. Protagonistas na Sociedade Civil: Redes e Centralidades de Organizações Civis em São Paulo. 
Revista de Ciências Sociais, Rio de Janeiro, Vol. 50, no 3, d. 465-498, 2007. Disponível em www.anpocs.org.br. Acesso em 05/03/2010.

LAVALLE, A. G; HOUTZAGER, P.P; CASTELO, G. Representação Política e Organizações Civis: Novas instâncias de mediação e os desafios da legitimidade. Revista Brasileira de Ciências Sociais, Rio de Janeiro, Vol. 21 No 60, Fev, 2006. Disponível em: www.anpocs.org.br. Acesso em 05/03/2010.

MAIMON,D.; BAER,W.; GEIGER, P.P. O impacto regional das políticas econômicas no Brasil. Revista Brasileira de Geografia, Rio de Janeiro, n3, p. ,Jul/Set,1977. Disponível em: www.biblioteca.ibge.gov.br. Acesso em 11/10/2009.

MARIZ, V. A política externa do Brasil nos últimos 50 anos. Revista da Escola Superior de Guerra, Rio de Janeiro, Ano XIII, No 37, v.1, no Dez. 1983. Disponível em: www.esg.br. Acesso 01/06/2009.

MEDEIROS JUNIOR, H. A política econômica na cidade do Rio de Janeiro. Coleção Estudos Cariocas. Rio de Janeiro, Plano Estratégico/Prefeitura da Cidade do Rio de Janeiro, No 20031101, p. 113,Nov. 2003. Disponível em: www.armazemdedados.ri.gov.br. Acesso em $12 / 10 / 2009$.

Planejamento ausente, resignação presente: diferenciais negativos do desenvolvimento carioca entre 1991 e 2000. Coleção Estudos Cariocas. Rio de Janeiro, IPP/Prefeitura da Cidade do Rio de Janeiro, No 2009/202, p. 1-24, Dez.2009. Disponível em: www.armazemdedados.ri.gov.br. Acesso em 12/10/2009.

MORRIS, F.B. A geografia social no Rio de Janeiro. Revista Brasileira de Geografia, Rio de Janeiro, n1, p. 3-70, Jan/Mar, 1973. Disponível em: www.biblioteca.ibge.gov.br. Acesso em 26/08/2009.

O ESTADO DE SÃO PAULO. Aspectos Humanos da Favela CariocaEstudo sócio-econômico elaborado por SAGMACS. Suplemento Especial, abril de 1960.

O GLOBO. Guanabara + Rio de Janeiro: A crise dos trinta. Suplemento Especial, março de 2005.

OLIVEIRA, Fabrício Leal. Notas sobre as estimativas do déficit habitacional no Brasil e no Rio de Janeiro. Coleção Estudos Cariocas. IPP e SMU,2007. Disponível na Internet www.armazemdedados.ri.gov.br. Arquivo consultado em 26/06/2009. 
OLIVEIRA, W.F. Planificação Econômica. Revista Brasileira de Geografia, Rio de Janeiro, n3, p.383-388, Jul/Set, 1963. Disponível em: www.biblioteca.ibge.gov.br. Acesso em 06/11/2009.

PINTO, M.N. A cidade do Rio de Janeiro: evolução física e humana. Revista Brasileira de Geografia, Rio de Janeiro, n2, p. 191-232, Abr/Jun, 1965. Disponível em: www.biblioteca.ibge.gov.br. Acesso em 08/05/2009.

REIS, A.C.F. O planejamento Regional - Suas características e particularidades, ensinamentos decorrentes de experiências estrangeiras.

Revista Brasileira de Geografia, Rio de Janeiro, n4, p.3-43, Out/Dez,1958. Disponível em: www.biblioteca.ibge.gov.br. Acesso em 12/06/2009.

RODRIGUES, C.C. As relações entre Brasil e os Estados Unidos. Revista Brasileira de Geografia, Rio de Janeiro, n2, p. 251-260, Abr/Jun, 1964. Disponível em: www.biblioteca.ibge.gov.br. Acesso em 07/04/2009.

SANTANA, M.N.C. Elaboração de um modelo de estrutura espacial para o sistema administrativo do novo Estado do Rio de Janeiro. Revista Brasileira de Geografia, Rio de Janeiro, n3, p.31-92, Jul/Set,1976. Disponível em: www.biblioteca.ibge.gov.br. Acesso em 11/10/2009.

SANTOS, Milton. Geografia e Desenvolvimento Econômico - A contribuição dos geógrafos ao planejamento. Revista Brasileira de Geografia, Rio de Janeiro, n4, p. 539-550, Out/Dez, 1959. Disponível em: www.biblioteca.ibge.gov.br. Acesso em 19/04/2009.

SEREBRENICK, S. Planejamento regional. Revista Brasileira de Geografia, Rio de Janeiro, n1, p. 95-118, Jan/Mar, 1963. Disponível em: www.biblioteca.ibge.gov.br. Acesso em 13/07/2009.

SOARES, M.T.S. Nova Iguaçu: absorção de uma célula urbana pelo grande Rio de Janeiro. Revista Brasileira de Geografia, Rio de Janeiro, n2, p. 155-255, Abr/Jun, 1962. Disponível em: www.biblioteca.ibge.gov.br. Acesso em 04/08/2009.

SOBRAL, Silvio. Plano Estratégico da Cidade do Rio de Janeiro. Publicado em Rio Estudos No 78. 2002. Disponível na Internet www.armazemdedados.gov.br. Arquivo consultado em 26/09/2009.

TEIXEIRA, A. T.; GUERRA, I. A. L. Subsídios para uma nova divisão política do Brasil. Revista Brasileira de Geografia, Rio de Janeiro, n2, p. 169208 , 1960. Disponível em: www.biblioteca.ibge.gov.br. Acesso em 22/09/2009.

TEIXEIRA, M.P.V. Padrões de Ligações e Sistemas Urbano: uma análise aplicada aos Estados da Guanabara e Rio de Janeiro. Revista 
Brasileira de Geografia, Rio de Janeiro, n3, p.16-55, Jul/Set, 1975. Disponível em: www.biblioteca.ibge.gov.br. Acesso em 06/09/2009.

VETTER, D. M.; MASSENA, R. M. R.; RODRIGUES, E. F. Espaço, valor da terra e equidade dos investimentos em infraestrutura do município do Rio de Janeiro. Revista Brasileira de Geografia, Rio de Janeiro, n1,2,p. 32-71, 1979. Disponível em: www.biblioteca.ibge.gov.br. Acesso em 11/10/2009.

\section{ARTIGO EM JORNAIS}

ALVAREZ, R; JUNGBLUT,C;BECK;M. O artigo descreve que os cortes do governo federal no orçamento público atingirão o PAC e a área social comdestaque o programa Minha Casa, Minha Vida. O Globo, Rio de Janeiro, 1 mar. 2011, O País, p. 3.

ANTUNES, L. O artigo descreve que o site da Google modificará seus mapas sobre o Rio para que favelas não tenham mais destaque do que bairros. O Globo, Rio de Janeiro, 26 abr. 2011, Rio, p.17.

BARRETO, D. O artigo descreve que moradores e vizinhos de Exfavelas discordam de critérios da prefeitura porque muitas apresentam saneamento incompleto, obras inacabadas e urbanização precária. $\mathbf{O}$ Globo, Rio de Janeiro, 30 mai. 2011, Rio, p. 13.

BASTOS, J; LIMA, L; CANDIDA,S. O artigo descreve que o governo do estado planeja erguer torres sobre a rodoviária Novo Rio e a prefeitura defende a transferência de rodoviária para terreno em Irajá. O Globo, Rio de Janeiro, 18 jun. 2011, Rio, p. 23.

BASTOS, I; SCHMIDT, S. O artigo descreve que a Câmara Municipal aprova pacote de isenção ou descontos de IPTU, ISS e ITBI na Região Portuária em vista do Projeto de Revitalização para o região. O Globo, Rio de Janeiro, 5 dez. 2009, Rio, p. 17.

BASTOS, J. O artigo descreve que a concessionária Porto Novo assumiu os serviços públicos municipais na Zona Portuária e em parte do Centro que se encontram desassistidos e em péssimas condições. $\mathbf{O}$ Globo, Rio de Janeiro, 14 jun. 2011.

BASTOS, I. Consórcio formado pelas construtoras OAS, Carioca Engenharia e Odebrecht assume serviços como coleta de lixo, iluminação 
pública, pavimentação e ordenamento do trânsito por 15 anos na Região Portuária. O Globo, Rio de Janeiro, 14 jun. 2011, p.8.

BASTOS, I. O artigo descreve que a Região do Porto vem recebendo canteiros de obras para a perfuração de três túneis na região para receber a circulação viária alterada com a demolição do Elevado da Perimetral. As obras serão executadas pela concessionária Porto Novo. O Globo, Rio de Janeiro, 4 jul. 2011, Rio, 2 ${ }^{\mathrm{a}}$ d, p.12.

CANDIDA. S. O artigo descreve as intervenções na Barra para viabilizar a Transcarioca vêm desapropriando imóveis ao longo do traçado da obra que se tornam onerosas aos cofres públicos, principalmente pelos numerosos recursos dos proprietários na justiça. O Globo, Rio de Janeiro, 18 mar. 2011, Rio, p.17.

COSTA, J; MARQUEIRO, P E BRANDÃO, T. O artigo descreve que há 100 anos o Rio de Janeiro começava a ser planejado a partir das intervenções urbanísticas no processo de ocupação e expansão da cidade. O Globo, Rio de Janeiro, 5 nov.2005. Suplemento Especial, p. 1-12.

DAFLON, R; SCHIMIDT,S. O artigo descreve que especialistas do IPP discutem reclassificação de 44 comuniddes e listam pré-requesitos para um lugar deixar de ser favela. O Globo, Rio de Janeiro, 5 jun. 2011. Rio, ExFavelas na Berlinda, p.22.

DAFLON, R. O artigo descreve o vencedor do concurso Porto Olímpico no auditório do IAB- Instituto dos Arquitetos do Brasil que prevê a instalação de equipamentos para os jogos de 2016 na Região Portuária. O vencedor se associou ao escritório catalão do arquiteto Ignasi Riera. O Globo, Rio de Janeiro, 29 jun. 2011. Rio, p.20.

DAFLON, R; BERTA,R. O artigo descreve que as obras do PAC na Rocinha estão paradas aguardando liberação de verbas do governo federal. 0 Globo, Rio de Janeiro, 20 jul. 2011, Rio, p. 14.

DUARTE, A. O artigo descreve que a cidade do Rio de Janeiro tornouse um ancoradouro de projetos que não acontecem porque projetos não estão incluídos no planejamento da cidade e não têm continuidade devido aos problemas fundiários da área. Para que os projetos se realizem é preciso que o município se planeje e realize parcerias com a União e proprietários dos terrenos. O Globo, Rio de Janeiro, 1 ago. 2008. Eleições 2008/O que muda uma cidade, O país, p.9.

FABRINI, F; MAGALHÃES, L.E. O artigo descreve que o TCU- Tribunal de Contas da União suspende licitação de terminal do Porto porque relatório apontou indícios de sobrepreço. O Globo, 1 out. 2011. Rio, Rio 2016, p.26. 
GALDO, R; DAFLON, R. O artigo descreve que os conjuntos habitacionais construídos para receberem a população removida das favelas dos anos 50,60,70 encontram-se desassistidos pelo governo, carentes de investimentos e dominados por traficantes e milicianos. 0 Globo, Rio de Janeiro, 13 mai. 2011, Rio/Vida em Blocos, p.14.

LISBOA, V. O artigo descreve a implosão do prédio do extinto Moinho Marilu faz parte do projeto privado de revitalização do Porto. O Globo, Rio de Janeiro, 27 jun. 2011, Rio, p. 15.

LEITE, R. O artigo descreve que os conflitos gerados pela extensão da linha 4 do metrô. O clube de engenharia solicita maior acesso à pesquisa do traçado e todas as informações relativas à futura expansão da rede. 0 Globo, Rio de Janeiro, 13 set, 2011, Rio, p.17.

MAGALHÃES, L.E. O artigo descreve que a Vila Autódromo entre na reta final e a minuta de edital prevê remoção da favela Parque Carioca até 2013 para obras do Parque Olímpico. O Globo, Rio de Janeiro, 4 out. 2011. Rio, Depois do Rock'n Roll, p. 12.

MAGALHÃES, L.E. O artigo descreve que a maioria das indenizações das desapropriações para a construção da BRT's- Bus Rapid Transit é paga em juízo e moradore reclamam dos valores calculados. O Globo, Rio de Janeiro, 28 mai. 2011, Rio 2016, p. 24.

MAGALHÃES, L.E. O artigo descreve que as detonações realizadas nas obras de expansão da linha 1 à linha 4 do metrô causa polêmicas com os moradores que segerem um outro traçado alternativo. 0 Globo, Rio de Janeiro, 25 jul. 2011, Rio, p. 22.

MAGALHÃES, L.E. O artigo descreve que a prefeitura reconhece o erro de ter mantido os índices que definem o valor do metro quadrado dos terrenos da gestão anterior sem discutir parâmetros urbanísticos que atingem os IAT's - Índice de Aproveitamento de Terreno dos bairros. Tal displicência da prefeitura foi considerada pela sociedade civil organizada como uma medida favorecedora da especulação imobiliária. O Globo, Rio de Janeiro, 6 jul. 2010, Rio, p. 15.

MAGALHÃES, L.E. O artigo descreve que emenda à revisão do Plano Diretor da cidade do Rio de Janeiro modifica classificação de bairro da llha do Governador para permitir obra do novo terminal pesqueiro (projeto do Ministério da Pesca e Aquicultura). O Globo, Rio de Janeiro, 07 jul. 2010, Rio.

MAGALHÃES, L.E. O artigo descreve que emenda facilita concessão de áreas públicas e abre brecha para multiplicação de camelôs e exploração de barracas em praças por empresas 
MAGALHÃES, L.E. O artigo descreve que a prefeitura se mobiliza para derrubar 135 pontos que a desagradam no Novo Plano Diretor. O Globo, Rio de Janeiro, 31 ago. 2010, Rio, p.14.

NOGUEIRA, I. O artigo descreve que a falta de planejamento está aumentando o índice de criminalidade em Macaé pela migração desordenada. Folha de São Paulo, São Paulo, 15 mai, 2011. Caderno Mercado, B1.

OLIVEIRA, F. O artigo descreve que a Rodoviária Novo Rio está fora do Projeto de Revitalização do Porto. O Globo, Rio de Janeiro, 17 jun. 2011. Negócios \&Cia.

ROCHA, C d d. O artigo descreve os períodos de governo de César Maia (1993-1997, 2001-2004 e 2005-2008) que promoveu o ordenamento urbano, o controle financeiro, a construção da Linha Amarela e a implantação dos programas Rio-Cidade e Favela-Bairro nos dois primeiros mandatos e 0 abandono administrativo na sua última gestão. O Globo, Rio de Janeiro, 14 dez. 2008. Suplemento Espacial, p. 1-12.

ROCHA, C; MAGALHÃES, L. E. O artigo descreve que prefeitura não acha herdeiros para pagar $\mathrm{R} \$ 3,1$ milhões por imóvel a ser desapropriado para a construção da Transoeste. O Globo, Rio de Janeiro, 22 abr. 2011, Rio, p.10.

ROCHA, C. O artigo descreve que o Projeto para conter inundações é contestado pelo Clube de Engenharia que alega se tratar de um projeto de elevado custo de manutenção sem garantias de resolver o problema típico da cidade. O Globo, Rio de Janeiro, 22 ago. 2011, Rio, p.12.

SANTOS, R. O artigo descreve que o Grupo Ação Ecológica entram com uma representação no Ministério Público contra a construção de hotéis na Barra da Tijuca. O Globo, Rio de Janeiro, 7 out. 2011. Rio, p.24. 


\section{ANEXOS}

\section{ANEXO A \\ ENTREVISTA COM O EX-MINISTRO DO PLANEJAMENTO JOÃO PAULO DOS REIS VELLOSO}

Hoje, dia 18 de julho de 2011, estamos aqui na sede do INAEInstituto Nacional de Altos Estudos com o ex: Ministro do Planejamento dos governos de Médici e Geisel de 1969 a 1979, o Sr. João Paulo dos Reis Velloso que foi criador e presidente do IPEA- Instituto de Pesquisas Econômicas Aplicadas, e criador do FINEP- Financiadora de Estudos e Projetos em 1967, empresa pública vinculada ao MCT- Ministério de Ciência e Tecnologia. Atualmente, é presidente do IBMEC- Mercado de Capitais, Membro do CDES- Conselho de Desenvolvimento Econômico e Social da Presidência da República, Professor da EPGE- Escola de Pós-Graduação em Economia, da Fundação Getúlio Vargas e Presidente do Fórum Nacional com sede no INAE.

- Sr. Reis Velloso: sou pesquisadora do curso de doutorado do Instituto de Geografia da Faculdade de Filosofia, Línguas e Ciências Humanas da Universidade de São Paulo sob a orientação da Professora Doutora Ana Maria Marques Camargo Marangoni. Desenvolvemos um trabalho desde 2008 que tem por objetivo principal avaliar o papel da cidade do Rio de Janeiro na perspectiva do ordenamento territorial urbano a partir dos anos de 1970, quando verificamos a constituição de organismos de desenvolvimento urbano e a institucionalização do planejamento nos três níveis de governo com a finalidade de ordenar a concentração urbana das metrópoles, oriunda das migrações com base em numerosos problemas urbanos que se agravaram ao longo do tempo. E isso em função de vários fatores inclusive a mudança da concepção do planejamento refletido nas leis, normas, planos e programas nas últimas décadas.

1- No período em que o governo elaborou o I PND e o II PND, o Sr, como Ministro do Planejamento, esperava-se a efetiva institucionalização de um sistema "integrado" de planejamento abrangendo não somente a fase de elaboração de planos e projetos, mas, também as etapas posteriores de acompanhamento, avaliação, revisão e controle ou seja: destacar o caráter do planejamento como 
processo, evitando o caráter descontínuo e intermitente, um dos defeitos mais comuns desse processo. Como o $\mathrm{Sr}$ avaliaria a proposta de planejamento com base nos resultados desse período e o atual sistema de planejamento do governo?

(Reis Velloso)- - Nós talvez pudéssemos dizer que realmente o planejamento institucionalizado sob a forma de sistema, de modo que a Secretaria de Planejamento da Presidência da República de que eu era ministro, era o órgão central e em todos os ministérios na secretaria geral como se chamava a época havia a unidade de planejamento, a unidade de execução de acompanhamento da execução e controle dentro da idéia de que se não houvesse controle da execução, não haveria execução. E Isso realmente o que acontece. E há um ponto a salientar é que o planejamento era da orla da Presidência da República porque o presidente Geisel me perguntou: se eu achava que planejamento deveria ser um ministério. Eu respondi: ou é órgão da Presidência da República ou não deve existir porque o planejamento é uma entidade auxiliar do presidente dá coordenadas. Como eu já disse havia o sistema de planejamento e havia também o sistema de orçamento que é de extremamente importante porque garantia os recursos para execução e fazia também a articulação com o setor privado porque os projetos eram conjuntos do governo com o setor privado ou havia um sistema de incentivos que cabia ao governo e a implementação ao setor privado. De modo que a minha conviç̧ão era ou é órgão da presidência ou não vai funcionar, de modo que nós tínhamos também uma outra dimensão que era da chamada reforma administrativa para que 0 governo funcionasse de forma descentralizada e com flexibilidade. O IPEA, por exemplo era integrado a esse sistema de planejamento. Eu recebia os estudos do IPEA, por exemplo, para elaborar o II PND, quando desabou sobre o Brasil, a primeira crise do petróleo, outubro de 1973, nós já tínhamos vários estudos em andamento. E foi graças a esses estudos que nós podemos dar uma resposta adequada. Foi diferente do caminho seguido pelos outros países porque os países desenvolvidos em geral fizeram uma recessão e no caso brasileiro nós não fizemos recessão. Nós desaceleramos a economia a taxa de crescimento veio caindo. Nós tínhamos passado por uma fase de alto crescimento $10 \%, 11 \%$ ao ano no PIB e $13 \%$ ao ano na média nas exportações de modo que nós fomos desacelerando e em 1977/78 já estava em 5\%. E porque mantivemos o crescimento mesmo desacelerado? Por que o governo tinha de investir e o setor privado tinha de fazer enormes investimentos nas grandes prioridades do II PND. De um lado energia, principalmente energia elétrica e petróleo, houve grandes programas nessa área e foi nessa época que se descobriu o primeiro grande campo de petróleo no Brasil, na Bacia de Campos, novembro de 1974. De outro lado, nós tínhamos os grandes programas de investimentos nos chamados insumos industriais básicos. Que bicho é esse? São setores como siderurgia, petroquímica, celulose, papel, 
metais não ferrosos, minerais não metálicos em que 0 Brasil era potencialmente muito competitivo, mas em que na realidade nós éramos grandes importadores. Então, além disso, houve um programa de investimentos em certos segmentos da área de bens de capital ou seja: equipamentos. Eram essas as prioridades do II PND e ao mesmo tempo nós estávamos fazendo o desenvolvimento dos Cerrados que até então eram considerados uma área sem maior importância e através de um estudo feito pelo IPEA ficou claro que era enorme o potencial dos cerrados. Nós criamos um programa específico chamado POLOCENTRO para o desenvolvimento dos Cerrados. Hoje nós sabemos que existem Cerrados naquele tempo era principalmente Goiás, Mato Grosso e Oeste de Minas. Hoje, nós sabemos que existem Cerrados no sul do Pará, no sul do Maranhão, sul do Piauí, oeste da Bahia. Isso é uma grande riqueza nacional de modo que foi possível fazer tudo isto durante a grande crise do petróleo e ao lado disso havia um grande programa cultural: nós fizemos um programa de cidades históricas, em que havia a restauração de cidades inteiras no nordeste, em Minas Gerais. As cidades históricas de Minas Gerais foram restauradas inteiramente e houve também restauração no Estado do Rio de Janeiro, no Espírito Santo. Pelo menos cinco ou seis cidades do nordeste foram completamente restauradas. Eu me lembro bem, uma das cenas mais bonitas que eu vi na vida, numa noite que dormi na cidade de Marechal Deodoro, ao longo do Rio São Francisco, a cidade tinha acabado de ser restaurada com lampiões do século XVIII começo do século XIX, de modo que foi possível fazer tudo isso, é claro muito desses programas só foram sendo concluídos já no começo dos anos 80 , mas estava tudo encaminhado graças ao sistema de planejamento que havia sido montado.

2- Quais seriam as concepções de planejamento desse período em relação a atual?

(Sr. Reis Velloso) - Eu acho que a concepção do planejamento deve ser a mesma. Ela está num estudo de um grande escritor espanhol, Salvador de Madariaga. Ele diz: "o planejamento é para ordenar as forças vivas da sociedade". Não é planejamento de tipo GOSPLAN da União Soviética. Ele impulsiona a iniciativa privada. Ele é complementar a iniciativa privada. Só faz aquilo que o setor privado não tem condições de fazer. O Brasil tinha naquela época, uma excelente infraestrutura, mas eram entidades estatais que depois foram tenderam naturalmente a ser desprivatizadas. (????) Hoje você pode fazer através de concessões. Ótimo, ótimo! Há um outro ponto: que é o que nós chamamos de a grande concepção. Isso significa, Projeto de Brasil. É preciso ter um projeto de país, por trás. E no meu entender já houve três grandes concepções, três projetos de país. No governo Vargas, no governo JK 
e no governo Geisel. E já está na hora de termos uma nova grande concepção. Para onde vai o país? Como nós queremos que seja o Brasil que nós vamos entregar à próxima geração? É isso que eu colocaria para os planejadores de hoje.

3- De que forma poderíamos chegar a essa grande concepção? Que caminho devemos percorrer?

(Sr. Reis Velloso) - Existe hoje a possibilidade (ele se levanta e busca três livros). Aqui. A economia do conhecimento. Nós podemos usar a economia do conhecimento para criar uma era de grandes oportunidades para o Brasil. Que é economia do conhecimento? No nosso entender, ...Veja aqui! O Brasil e a economia do conhecimento. O modelo, a primeira sistematização da economia do conhecimento foi feita pelo Banco Mundial no seu relatório sobre desenvolvimento de 1998/99. E nós tomamos as idéias e adaptamos ao caso brasileiro e fizemos o modelo em duas dimensões: a primeira dimensão é levar o conhecimento, no sentido amplo, para todos os setores da economia com o objetivo de dar conteúdo de conhecimento a todos eles. Torná-los setores de média e alta tecnologia, mesmo a agricultura, mineração. Acabar com essa idéia de setores primários, commodities primárias. Não. Todos os setores são de médio e alto controle tecnológico. A outra dimensão que é econômico e social, é levar o conhecimento novamente em sentido amplo, a todos os segmentos da sociedade para evitar as exclusões. Exclusão educacional, exclusão digital, exclusão cultural e com base nessa idéia da economia do conhecimento, nós podemos aproveitar as grandes oportunidades de que dispõe o Brasil, tanto na área de setores intensivos em recursos naturais como - Pré-Sal, como na área de tecnologia de informação, tecnologia de telecomunicações ou uma grande tecnologia do século XXI que é biotecnologia à base da biodiversidade. $\mathrm{O}$ Brasil tem a maior biodiversidade do mundo: na Floresta Amazônica, nos Cerrados, na Caatinga, na Mata Atlântica, no litoral brasileiro de modo que existem todas essas grandes oportunidades. Eu disse: o Brasil tem a maior biodiversidade do mundo, mas, só usa $1 \%$ da biodiversidade que tem. Então é uma oportunidade não aproveitada.

4- Quanto ao planejamento regional executado no Brasil pelo governo federal, foi criado um aparato institucional como as superintendências e os fundos de incentivos fiscais, no final da década de 50 e nos anos $60 \mathrm{com}$ a fundação da SUDENE, da SUDAM, do SUDESUL, do SUDECO e SERSE (órgão extinto, de pouca divulgação e de acervo documental muito reduzido direcionado para a região sudeste.) Quanto aos estímulos fiscais e financeiros do governo federal na política regional, como a região sudeste se inseria nesse contexto? 
(Sr. Reis Velloso) - Vamos dar a nossa concepção de desenvolvimento regional. No nosso entender desenvolvimento regional é para o nordeste e a Amazônia. Ou seja: as regiões menos desenvolvidas do país e a concepção de ser de aproveitamento de oportunidades. Quais são as oportunidades que existem para o desenvolvimento do nordeste? Quais são as oportunidades que existem para o desenvolvimento da Amazônia? No caso da Amazônia, antes de tudo, a grande, a enorme oportunidade é a biotecnologia à base da biodiversidade, eu já mencionei. O governo pode apoiar projetos no sudeste ou de iniciativa dos estados ou de iniciativa do próprio governo federal. No nosso entender isso não constitui desenvolvimento regional. Os próprios ministérios podem desempenhar o papel que cabe ao governo federal. Agora, é importante que haja, por exemplo: um plano de desenvolvimento da Bacia do Rio São Francisco, um plano de desenvolvimento da Bacia do Parnaíba, de passagem eu sou de Parnaíba, Piauí) e, como disse: um plano para o nordeste e um para Amazônia, mas sempre naquela visão de aproveitamento de oportunidades.

5- E como o Rio de Janeiro se inseria nessa política regional direcionada para a região sudeste?

(Sr. Reis Velloso) - Incentivo fiscal no sentido que se desenvolveu no Brasil, nossa déia deveria ser apenas para o nordeste e a Amazônia, e hoje já até avançamos. Vamos pesquisar as oportunidades e vamos tornar uma realidade essas oportunidades. Ainda existem mecanismos aí com o Banco do Nordeste, como o Banco da Amazônia, eu já citei o caso da CODEVASF que trata da Bacia do São Francisco, da Bacia do Parnaíba. E no mais você pode usar a ação dos ministérios e ter uma concepção de desenvolvimento metropolitano que desapareceu do Brasil. Extinguiram as regiões metropolitanas. Foi um erro! Por que nós vemos aqui: Região Metropolitana do Rio de Janeiro, Região Metropolitana de São Paulo. Seria boa idéia ter um mecanismo de caráter metropolitano, mesmo que não tenha personalidade jurídica. Não precisamos criar o órgão. Mas criamos um grupo executivo, um comitê chamar, mas que tenha a visão da região metropolitana porque não é possível separar o município do Rio de Janeiro, por exemplo, de Duque de Caxias, de Nova Iguaçu, de Nilópolis, de Japeri. A mesma coisa acontece em São Paulo. Não há solução de continuidade e até do ponto de vista de pobreza. Nós estamos querendo fazer um plano de desenvolvimento de vinte comunidades da Região Metropolitana do Rio de Janeiro. Falando claramente, vinte favelas. E várias delas vão estar fora do município do Rio de Janeiro. Essas que eu citei. Mas, vão desde a Rocinha, Santa Marta, Pavão e Pavãozinho, e aí vai Complexo da Maré, Complexo de Manguinhos que vai as favelas. Só o Complexo da Maré são dezesseis favelas. E vai descendo até chegar à Baixada Fluminense e lá você toma os principais municípios favelados, para fazer um plano de desenvolvimento. Desenvolvimento econômico, social e cultural. Quando há 
dois anos atrás, nós fizemos um programa de integração de favelas, eram dez as lideranças das favelas que fizeram as propostas e todas pediram cultura de modo que o desenvolvimento cultural tem de ser incluído. Mas voltando ao ponto. Nós temos que ter numa visão de desenvolvimento metropolitano, região metropolitana. ( Ele anuncia que eu só tenho mais um pergunta a fazer e eu peço pelo menos mais duas e ele concorda)

\section{6- Insistindo: qual era o papel do Rio de Janeiro na política regional?}

(Sr. Reis Velloso) - Foi à época em que se fez a fusão da Guanabara e o Estado do Rio de Janeiro porque não tinha o menor sentido um negócio chamado Estado da Guanabara. Havia a necessidade de uma base física para fazer o desenvolvimento do ponto de vista agrícola, industrial, de certos serviços e foi feita a fusão. O Célio Borja fez a parte jurídica e política; e eu fiz a parte econômica, de modo a... Qual foi a concepção? Nós temos São Paulo, a grande força econômica do país. A idéia era que houvesse uma outra área que também tivesse grande densidade econômica e fizemos a separação, divisão de Mato Grosso em Mato Grosso do Sul para evitar que ficasse uma área grande demais que fosse trazer desequilíbrios. A idéia toda é do equilíbrio dentro do país. Então veja no caso fusão, no outro divisão. São Paulo deixa como está. Agora em todos os casos visão metropolitana, visão metropolitana.

7- Consideramos a tamanha importância dos órgãos de conceituada credibilidade divulgadores de dados e informações de diversas naturezas como os econômicos, financeiros, produtivos, demográficos, físicos, sociais para o planejamento do governo como foi o IBGE e como foi o IPEA nesse período. Como o Sr.. avaliaria o papel do IBGE e do IPEA?

(Sr. Reis Velloso) - Nós fizemos uma reestruturação do IBGE que estava, isso foi na altura de 64/65. Criei um grupo de trabalho, que eu coordenava, eu era presidente do IPEA e fizemos então, a reestruturação do IBGE que foi transformado em fundação, como é hoje, porque em 65, o IBGE não havia apurado o censo de 1960. Então, para dar ao IBGE condições de funcionar bem porque é um papel fundamental, houve a transformação em fundação. Passou de autarquia à fundação; e no caso do IPEA que era um simples escritório, tanto que era EPEA: Escritório de Pesquisas Econômicas Aplicadas, com a reforma administrativa de 1967, ele foi transformado em fundação pública que é até hoje, já com uma outra função. A função do IPEA é tomar os dados do IBGE e pensar o país no médio e longo prazo elaborar os estudos necessários para que possa haver realmente o planejamento, a fim de que 0 
planejamento em si, não seja um órgão gigantesco. Assim, é que foi concebido o sistema e ao lado disso haviam órgãos de reforma administrativa para cuidar de uma administração pública que fosse eficiente, descentralizada e flexível. Lamentavelmente, a Constituição de 1988 que teve o grande mérito de criar no Brasil, de institucionalizar no Brasil: a República Democrática de direito, criou um monstrengo que é algo chamado Regime Jurídico Único. No meu entender, não tem o menor sentido. É incompatível com a boa administração pública. No caso do IPEA, por exemplo, o IPEA tinha a sua própria carreira. Não era parte da carreira de técnico de planejamento federal, porque as exigências para 0 IPEA eram muito maiores porque recrutavam gente com pós-graduação no exterior ou grandes especialistas de modo que quanto mais cedo possível, acho que devemos acabar com a RJU-Regime Jurídico Único.

8- O Sr.. acha que houve um esvaziamento da importância desses órgãos para o planejamento?

(Sr. Reis Velloso) - Não eles são usados de forma diferente, mas os dois funcionam bem e nada há que impeça que eles continuem desempenhando a função que eu acho que devem desempenhar naquela nova grande concepção que nós devemos ter. A única dificuldade é esse Regime Jurídico Único. Mas, talvez até mesmo isso seja superado. O IPEA tinha a sua própria carreira e depois quando se criou o RJU foi uma dificuldade até para o IPEA entrar na carreira geral do serviço público: técnico de planejamento. E nós temos que entender o seguinte: há órgãos em que o técnico de planejamento não desempenha funções muito sofisticadas. No IPEA, isso é vital! Quer dizer: que tem que haver alto nível. O IPEA tem conseguido manter o alto nível do seu pessoal, mas o RJU cria dificuldades. Ok?

(Entrevista encerrada duração de 40 minutos) 


\section{ANEXO B}

\section{Terceira Parle \\ A Urbanização do Distrito Federal e sua Repercussão Sobre o Problema das Favelas}

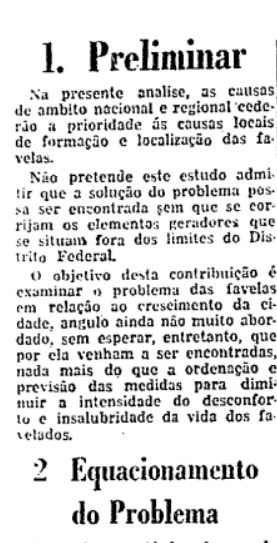

\section{Helio Modesto - Arquiteto}

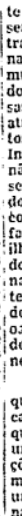

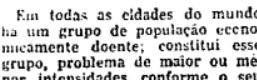
grupo, problema de maior ou me
nor intensidades, conforme o o se
rnconhecimento por parte das a

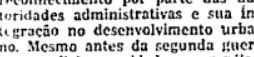
ra. Mesmo antes da segunda touct
ra muntial, as eidades européta
"onsideravam o problema da b bitaçà como uma das atribuicōece
principais de suas administraçéc

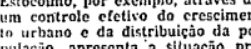

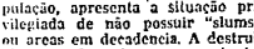

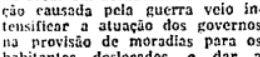
habitantes deslocados, e dar
oportunidade de adotar planos be

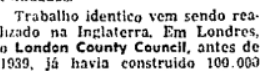
1939. ja havia construido 100.009
habitacóes de varios tipos o demo
lido

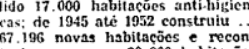
lruiu e reparou 80.000 habitaçóc
Todo esse estorgo is parte inte
arante de um plano de distribut krante de um plano de distribu
cáa de populacia, localizacio de i
durtrias e desenvolvimento do paj Nos Estados Unidos da Ameri
ca do Norte, pode.se mostrar reconhecimento da responsabiltda.
te das autoridadas municipais,
matriciona ado o Plano de Chicago que sirexiu em conseguencia
Grande Exposicâno de 1893 e v uer elaborado em 1909. O rel
lorio do Plano de Chicasoo 19009
do autoria de Daniel H. Durnham considerando os "slums" com
unma ameaca is saude ficica e mo
ral colo:
crto trecho: "Chicago ainda näo atingiu
ponto em que a municipatidade ne.

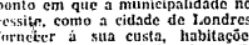
para as pessoas deslocadas pec
pressia ceconomica; mas, a meno que o problema seja encerando d
mediato, essa medida sera forca
ia per aqueles que, detradadados pe ia per aqueles que, defradados pe
as vida nos "slums, perderam

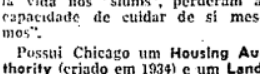

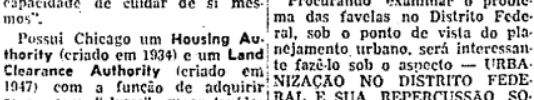

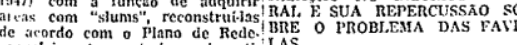

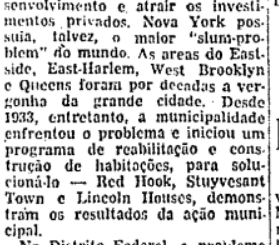
3. Resumo Historico da Evolução Urbana

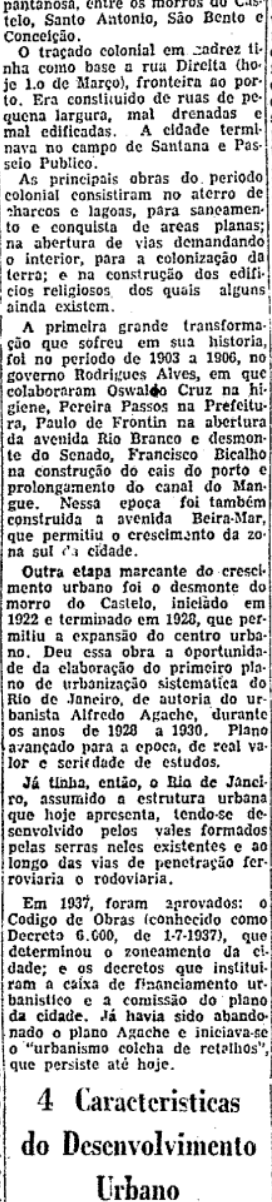
ais surpreende é a absoluta fa
de controle na distribuicão o adades de populaçáa para caá

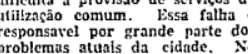

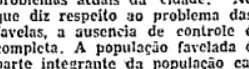

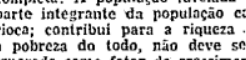
gnorada como fator dc crescimen aio pode deixar de, considers.llo
inda que sob aspectos negatisos.
Procurando examinar Procurando examinar o proble
a das favclas no Distrito Fed. A topogarafia do Distrito Federal,
uteús macicos montanhosos di Am très macicos montanhosos di.
idmudo- em duas areas principais
constituindo yarios vales com
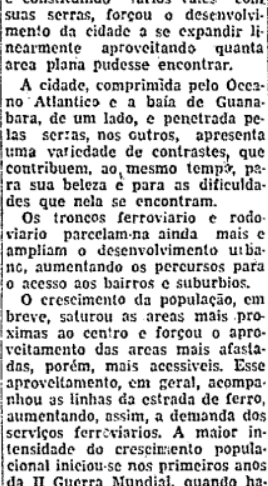
vin trandes dificuldades para a ob

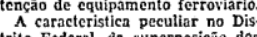

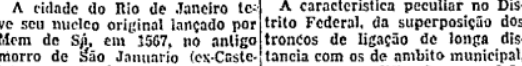

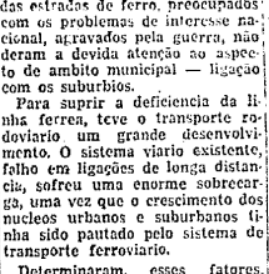

Determinaram, esses fatores, cos bairros mais proximos ao cen.
tro. A industria de construça ci.
vil, com o aprimoramento da tec. vica no omprego das estruturas
de conoceto armado, se firmou
foresceu a partir de 1930 . Os pre. floresceu a partir de 1930 . Os pre.
dios altos, cidificados na Epplanada
do Castelo e nos bairros da zona
sul da cidade, nostraram as novas sul da cidade, mostraram as novas
possibilidades de utilizaça dos dos
terrenos, colaborando, assim, para arrenos, colaborando, assim, para
a malor valorizacia dessas areas. A.
legislação reguladora do cresci.

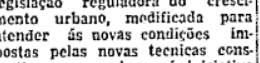

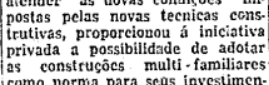

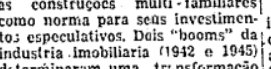

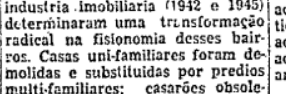

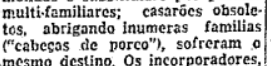
mesemo destino. Os incorporadores
para obter o malor numero de apartamentos em cada predio, fi.
xaram como padráa de construçán
03 mirimos permitidos pelos regu. oz mir imos permitidos pelos regu
amentos: visando, assim, maior Fentabilidade ao capital investido.
os apartamentos foram aumenta.
dos em numero e reduzidos em dos em numaero e r situsção atual de congestiong

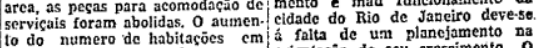

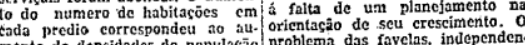

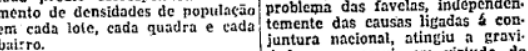

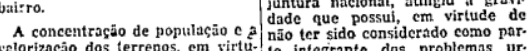

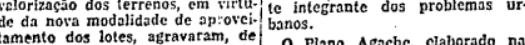
Corma acentuada, a provisāo de de o plano Agache, claborado na
forma

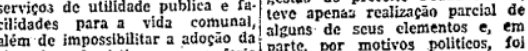

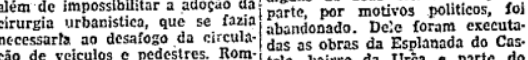

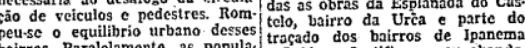
cóes economicamente menos faso. c L Leblon. Justifica o seu abando recidas foram obritgadas a deles se
retirarem e a se estabelecerem em

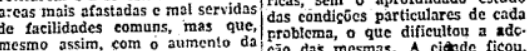
mesmo assim, com o aumento da
procura, sofreram grande valori. As altas densidades populacio. $\begin{aligned} & \text { teresse, como, por exemplo, os co } \\ & \text { nais do circunvalaçẫo dos morro }\end{aligned}$ Aais dos bairros que sofrerame so. para prevencāo das inundacōocs a

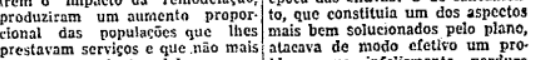
mentravam dentro deles as aco-j blema que, infelizmente, perdura modasūes que nezessitavam, nem até lioje.
os meios para pagar os elevádos rm, então, se alojar nos lugaraes importantes, visando a ellfrentar 0 sais proximos, indo engrošar a problema da urbanizziça do
to Federal, foram tomadas pela ce porce" existentes.
Embora täo haja estudos preci-

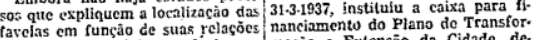

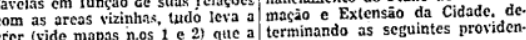
incidencia das favelas é maior pro- cias:
ximo aos bairros de maior densi- - Organizaçáo da Planta Geral

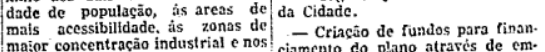
masor concentracão industrial e nos ciamento do plano atrasés de cm.
morros cujo aproveitamento a ex

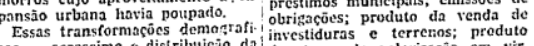

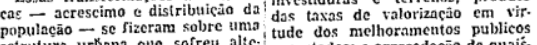

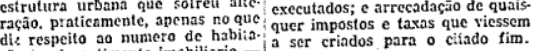

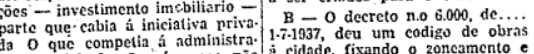

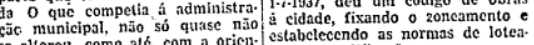
se alterou, como ató, com a oricn-
tacào fixada, piorou as condícoses

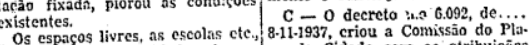

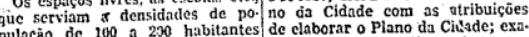
pos projetos de' zonea. vir a populacōós de $400,1.000 \mathrm{e}$ até
2.000 mento, planos e subestóes relativos
2 habitantes por hectare, com a quaisquer modificaçóes da cida. as mesmas areas e numero de uni. de; colaborar nos projetos de
dades que antes possuiam. A des. proporçấo entre o numero de es. verno da Uniáa, de forma a har mero necessario fez florescer a in.
colas 
monizstos com o plano gerat 'da Ira de realizacues sistematicas do
plano da Cidade; entrar em enten Himentos com as autoridades po blices e municipais do Fstado do ordenar as empreendimentus a q as nesmas se propunliam e que
pudessem interessar zonas do Dis trito Federal. Era a Comissio do duas subcomissūess:
$1-A$ Subcomissäo de Elator $1-\Lambda$ Subcomissia de Elathora
cầo, constituida pelo pessoal tec nieo e administrativo, pertencent is repartiçōes municipais. raçuo, de carater consultivo e in formativo, constituida por elemen tos designades pelos departamen
tos oficiais da vinižo ou da Prefei tura, c pelos das associaçies e cm. presas que, pela natureza de suas
atividades, pudessern opinar sobr - Plano da Cidade.
Apesar do texto dessas teis in dicar que scus autores posstiano, cada de planejamento urbano, são nao atingiu os niveis preten
d:dos; faltou-the a compreensão do problema urbanistico, abrantendo
o desenvolvimento do Distrito Federal como um todo homogeneo, abarcando o inter-relacionamento
dos problemas fisico, economico $e$ dos problemas fisico, economico
social. sem detrimento de um em buneficio de outro. Preocupou-se
a Comissão, apenas, com os' aspec tos construtivo, viartio e de em.
belczannento paisagistico e arqui.

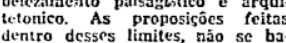
etonico. As proposisoes reitas
dentro desses limites, náo se ba
searam no real conhecimento dos searam no real conhecimento do
problemas que se propunham $r$ solver $e$, quando executadas. cau
saram consequencias perturbado ras ao equilibrio urbano. Fises fatos apontam uma das
maiores deficiencias do desenvol. imento do urbanismo no Brasil: a
fatta de escolas e tecnicos com orientasũo adequada. $\boldsymbol{A}$ atualizas dos conhecimentos urbanisticos. teratura, apresentando, por exem.
pio, os estagios finais do planej mento urkano em outros paise metodos e a formaçán pronissional
de sgus autores. Justificava-se, as. de sutus autores. Justificava-se, as.
sim, $\Rightarrow$ existencia, na legislacáa
entüo referendado, dos preceitos entuo referendad, dos precelta
attualizados de tecrica adiministro tiva de urbanismo. Aos respons
veis pela sua aplicasão faltava, en
tretanto, uma formaçáo adequa an estudo, ao equacionamento do
problentas, á analise dos elemento culizidos e a a formulaşâa das proposiçóes. A formasâa profissional
diaqueles a quem cabia o planeja. mento urbano carecia do conhe cessus que deveriam aplicar no As atribuiçōes que lhes foram
conferidas pela legtislação, foran conferidas pela legislaça, for
cumpridas empirica
mente. Pode isto ser facilmenta romprovado pelo exame dos ir
ballhos da Comissão do plano cidade durante o periodo de sua - Projeto de alargamento d av. Frasmo Braga - aprova
do em marso de 1938 . - Projeto para urbanização da
area da Esplanada do Caste. $10 .-$ aprovado em junho de
1039 . quadra compreendida entr
a rua 7 de Sctembro, prac
15 de Novembro 15 de Novembro e as ruas
Misericordia, Assemblétia

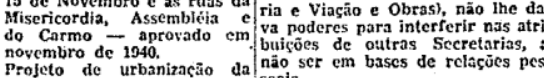
area atingida pelo prolonga-
mentu da avenida do Man. mentu da avenida do Man
oue, para a ubertura da ave aprousto $\mathrm{cm}$ dezembro do Proj:to para urbanização da lagoa Rudrito de Freitas e
Jardim Dotanico. Hocalizando
a Sociednde Hipien Erasileira a Sociednde Hipiea Erasileira
e o Clute Mili'ar -- aprovado em janniro de 104 . xa "non-edificandi" e regulan do longo da avenida da $\mathrm{T}$ juca - aprovado em fevere
ro te 19.31 . pravimento tixando o numero rem ennstruites nos nas avenida
Vicira Souto e Delphim Mo reira - aprovado em ma Projecto do plano de urbani 2açáo da Esplanadia do Cas
telo, resultante do desmont dreas adjacentos $c$ do pro
longamento da avenida Dia gonat - aprovado $\mathrm{cm}$ 3i de

- Projeto fixando o numero de
pavimentos dos predios a se.

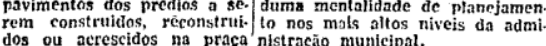
bro de 1941.
Projeto determinando o zo
neamento para o bairro Jar neamento para o bairro Ja
dim Visconde de Albuquer 1942. limites para a zuna industria de 1.7.1937 - aprovado em n. 7.366).
Irojeto determinando os ga na rua do Ouvidor - aprova cada caso, deixando de apre
centar o Plano da Cidade, para Esses projactos e estudos, por
Eso ter sido executada a planto dastral do Distrito Federal, fo
$m$ ralizados sobre o levants. mento parcial, que nâo sofrera se a sido elaborado em 1926 parta
rvir de tase ao Piano Agache dos scrvicos de utilizaşáa comum mento das favelas nos bairros atin
idos pelos referidos projetos. car), apenas fixando a subordina
são do Departamento á Secretaria sáa do de Viaçáo e Obras e os pa
Geral des dos ocupantes das chefias.
drōes
o trabatho realizado por este D partamento nada difere do que vi. sâo do plano. Nele transparcce a a
mesma preocupacäo com projetos fixaçáo de gabaritos e projetos

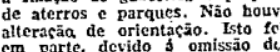
em parte, devido omissão de
responsaveis pelo Departamento
de Urbanismo e, em parte, a estru.
turaçáo administrativa da Prefeitu. turação administrativa da Prefeitu.
ra do Distrito Federal, que, sira do Distrito Federai, que, si.
tuando-o numa posisão hierarquica
sceundaria (stabordinado a Secreta.
ria e Viaçáo e Obras), não the da. va poderes para interferir nas atri.
buisōes de outras Secretarias,
não ser em bascs de relasúes pes.
soais. Houve, na realidade, um Diretor
do Departamento de Urbanismo que tentou alterar o sistema ate
entao sesuido, mas não o conss. cuiu por falta de apoio e compre.
ensão da administraçáa superior.

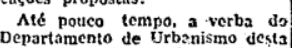
Departamento de Urbenismo des
cidade de mais de trós milhōes cidiade de mais de trés milhōes de
labitantes cra abcnas de Cr\$
$500.000,00$. Com esta soma. natid
poderia ter sido feito além do qua roi conseguido!
Os planos de urbanismo, com
têm sido elaborados até agora, vi. sando apenas orientas a desenvol.
vimento fisico da cidade, sāo.

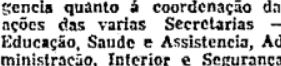
ministraçüo Interior e Seguranç
Viaçán e Obras, Agricultura e F nancas - num plano visando o d
senvolvimento global da cidade

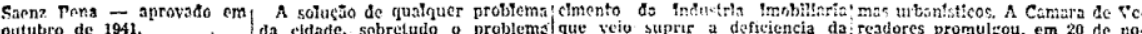

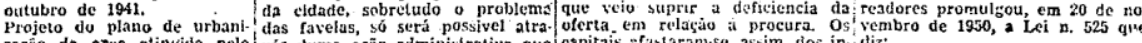
prolungamento da averida abranja a organizaçáa do todo à compreendido entre as pra. deira - aprovado $\mathrm{cm}$ dezem Projeto determinando as ga
baritos dos, predios a serem
construidos ou reconstruido Projeto determinarido novos ciativas muito aquém das necessi- aprovado $\mathrm{em}$ julhu de excuşäo. Deve-se essa situastá ao

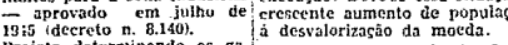

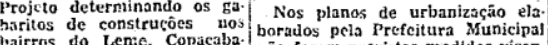
na, Ipanema e Leblon a não foram previstas medidas visan. aprovado em dezembro ede
19.45 tiecreto:tei n. 8.264).

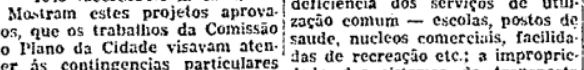
Surprecende verificar que a açán

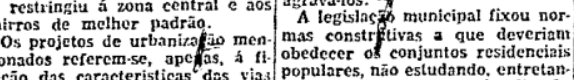
circulaçâa e á altura e ares de to, normas para a sua localizacâa

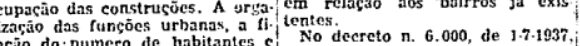

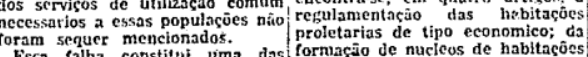
causas do aparceimento e incer. de tipo minimo e a de extingăn 0 decreto-lel 8.304, de 6.12-1945, prt. 346- Fixou as condiçūes da Cidade $\mathrm{cm}$ Departamento de rz as elasses proletarias em ZR3

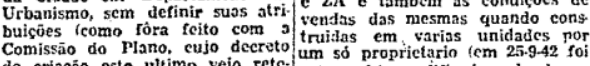
vimento fisico da cidade, são de.
ficientes c prejudiciais. A negli.
sencis quanto á coordenação dis 6.000) pelo Art. 346 do Decreto ấo dos problemas do Distrito Fe.

\section{Habitacões}

problema da provisão de labis-
pits

\section{.}

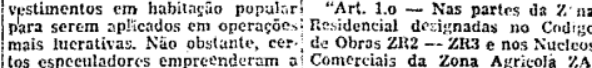

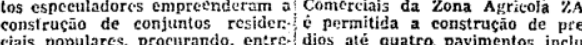
anto, compensar a deficiencia do sime, devendo as ruas cm que os batxamento do custo da construçüo materiais adotados.
Para salvaguardar a segurançal nemos forem edificados ter $p 0$
minimio doza metros de largura $e$ aitura das rachadas ter no maxi. 5 qu - Nas ruas ainda existen
tes com nove, dez ou onze metros (es com nove, dez ou onze metros de largura apenas essas constru-
cöes scräo permitidas Gesde que
o afastamento normal obrigatorlo

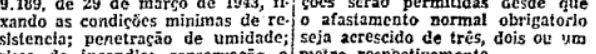
risco de incendio; conservaçäo metro respectivamente.
Art. 2.0 - Fiez elevado parz seis creto, sclar o interesse da iniciati. pavimentos e vinte e trés metros
de altura maxima o gabarito das a privada em investimentos para construscoes nas zonas ZR2, ZR3
construgáo de conjuntos residen. Z1, dessde que tenham frente para ciais proletarios.
$\mathrm{Na}$ estrutura da secretaria de Viaçio e Obras da Prefeitura do tentes ou projetadas.
Distrito Federal, foi criado o De. Art. 4. - Nas ruas de vida das

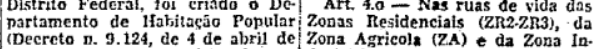

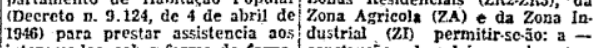
interesados, sob a forma de forne- construcàa de dois pavimentos,
imento de lipos de projetos de ca. quando as mesmas tiverem largu sas proletarias, que, se construidos. ra de scis metros no minimo, cor beriam, por preso de tabela, a cota
bota Convém ressaltar neste ponto
que os projetos de urbanizasáo pa. que os projetos de urbanizasáa pa
ra construçấo de conjuntos residen. ciais proletarios, eram aprovados
no Departamento de Edifíaçóses ou
no Departamento de Habitacio Po. pular sem passar pelo Departamen. to de Urbanismo fa Comissão do
Plano da Cidade foi, nelo Dec. n.
8.304, de 6 de de 7 embro de 1945 . Orbanismol.
Para contornar o problema cauPara contornar o problema cau-
sado pela diminuiçáo de eonstru
são de conjuntos residenciais do ipo popular, veio o Decreto $n$. cgulamentar um fato que vinhs
correndo ilegalmente -3 cons. ruşẩo de mais de um predio den
ro do mesmo lote. Foran indiscri minadiamente, atteradas as densi-
ades de populaćá etn quase toda anto, para avaliar a extensía des.
sa medida, é necersario relacioná com a Lei n. 83 , de 9 de jutho de
a "Nas partes da Zona Residencial
esiznada no Codigo de Obras ZR? ZR3 e nos nucleos comerciais, permitida a construsãa de predios,
até 4 pavimentos inclusive, devendo as ruas em que os mesmos fo.
rem cdificados ter no minimo dore
natros de lareura

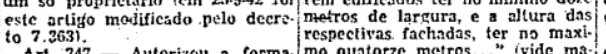
Art. $347-$ Autorizou a forma.
căo de nucleos de habitacuves bara. tas, de tipo minimo, em substitui-
caio ís farelas, 5 medida em que
lossem serho extintas, para ven. nobres. Art. 348 - Determinou que
construçäo ou formacão de corti. cos ou estalagens fosse absoluta
mente proibida, enu qualqu!ter zona.
Art. 349 - Estabeleceit que formaşäo de favelas, isto é, de con glomerados de dois on mais ca
scbres regularmente dispostos ou $\mathrm{cm}$ desordem, censtruidios com
$\mathrm{materins}$ improsisados e em desacorủo com as disposiç̄es do de
creto, não fosse absolutamente per mitida. - Nas ravelas existentes ou construir noros cascbres, ese. cutar qualquer obra nos que exis.
tem ou fazer qualquer construçäo".
Esses artigos podem ser consi. Esses artirgos podem ser consi
derados como que constituindo para enfrentar os problemas de
habitaça popular $\mathrm{e}$ habitaçós in salubres. Infelizmente, nẫo tive.
ram o alcance pretendido, permitindo a cvoluşāio do problema até
situaçăo encontrada atualmente.

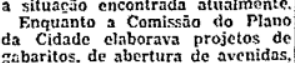
Fabaritos, de abertura de avenidas,
de urbanizasio de areas de des.
monte e de detathes de zoneamen. monte e de detalthes de zoneamen.
to sem se preocupar com a distri-
suição e densidade de populaçẫo o problema de habitasâo popular
aumeritava dia a dia. O Decreto n. 7.363 , de 25 de se
tembro de 1942, fixout as condicūe tembro de 1942 , fixou as condliçōes
(em arca, etc) que dercriarn aten.
der as habitaçoses proletarias para a n. 3).
Isto significa que, na maloris $\mathrm{da}$ Isto significa que, na maioria da
area urbana do Distrito Federal, é
facultada a construsão, em cada lo. e, de dois predios de quatro pavi-
mentos. Assim. os lotes uni-familia. es. com dencidades de populoşäo
e 100-200 habitantes por héctare, tiveram o sea anroveitamento mo-
dificado. podendo apresentar, cons. truidos ou reconstruices de acor
do com a lei, densidades superio. do com a lei, densidades superio.
res a 1.000 habitantes por hectare.
Como se ná bastasse autorizar
esse aumento na concentracĩo da

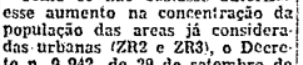
to n. 9.942 , de 29 de setembro de
1949 , veio delimitar a srea de ex. pansĩo urbana do Distrito Federal
(vide mapa n. 4) aumentando-a, as. sim, de muito em relaşấo á fixada
pelo zoneamento do Decreto 6.000 vide mapa n. 3). A nova area de.
limitada acompanhou as linhas.
tronco de circulacão já existentes. tronco de cireulacáa já ex existentes.
No mapa n. 4 pode ser constatada. a forma tentacular, com uima lar-
gura de 600 metros apenas, de tre. cho da area de expansão fixada.
Tals condicóes propiciarsom o crces.
cimento urbano ao longo das cita. cimento urbano ao longo das cita-
das vins, congestionando-as $\mathrm{e} \mathrm{crian.}$
do inconvenientes devido a sua $\mathrm{ex}$ tensão. Esse tipo de urbanizaciá,
conhecido como "Ribbon-develop. ment", costuma ser evitado pelas
desvantagens que oferece. Comparanciose o mapa in. 4, que
mostra a expansão urbana, cim o principais do Plano Diretor, d.) De. partamento de Urbanismo," nota.se
que o programa de. obras da Pre. reilura concentra-se numa area
muito redurida em relaçáa a que
foi fixada para a expansão da cióa e, ficande esta $\mathrm{sem}$, ao menos, o
eneficio de um sistema viario or. Para

existentes de descont:ole do con pulaşáo urbano, distribuição da po pulaşáo e paralclo aumento do va.
los dos terrenos, em virzude dos sociedades e firmes colctivas ou Acentuarn-se, nn cpoca, o aumen
dividuas

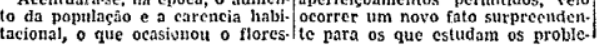

trés pavimento quando as mesmas tenham oito me
ros de largura e também quando tendo as: ruas de vila apenas seis
metros de largura, só existam edi. ricasoes de um lado; c c - constriçâ de quatro pavimentos, quando argura e também quando, tend so existam edificaçées de um lado.
Art 5.0 - Ficam também in Art 5.0 - Ficam também in. ine se refere o art. 2.0 desta lel mencionadas, quando situados en crem parte do bloco ou nucico comercial aprovado oficialmente; b qarteiräo, em que estiverem situa suas testadas ocupactas jor constru-
ges de uso comercial ou industrial 1.0 pavimento.
Art. 7.0 - $\mathrm{A}_{5}$ construçöes pre Artes nesta lei, quanto a oupaçaçao.
poderão cobrir até $70 \%$ da area tal do lote". A Lei 525, que substituin a Le
3 , além do aumento de densisado e populacâa e e edificacââ jón permi. ido por esta, vejo estender o acres atras areas que possuiam ruas nas do, modificar o indice de ocupa.
$\overline{3} 0$ do terreno de $60 \%$ pare $70 \%$. e Vereadores, sem estar basseada m estudos da situaçâa urbanistica das as esperansas de racionaliza A par dessa sequencia de leis, culativo do que o bem comum, sur.
giu a Iet 551 , de 5 de dezembra do 1950, permitindo, o que era dó intâo proibido, durante o prazo de
nco anos, isto é, 2 construsáo do asas de madeira. Condicionava a - prova de que o interessa. ava que nele pode construir, ca
o esteja pagando em prestaçós. pagamento $\mathrm{em}$ selos da taxa
- $\mathrm{Cr}$ 20,00; c apresentacáa do desenho do terreno onde será assi-
nalado o local e 2 area de constru5 metros do alinhamento da vi publica e de $1,50 \mathrm{~m}$ das divisas la Em 13 de janeiro de 1951, fol Lei pulo Decreto n.o 10.743, fixan. do a obrigatoriedade da constru-
câo de instzaçáes sanitarias em venaria, de instalasia de agua po
vel quando houvesse rede no 10 gradouro, de chuveiro, de tanque,
de vaso sanitario ligado á fossa hio ica ou essoto e de reservatori de litros. Só permitia o empre go de madeira de lei. Essas exigen
cias oneravam 2 construsasa da ca. 5a. de madeira, quase igualando-a,
em preso, á de alvenaria. $\mathrm{Na}$ epo ca, uma casa, atendendo a essas
condiçoes, com vinte e scis metros quadrados, custaria aproximada 


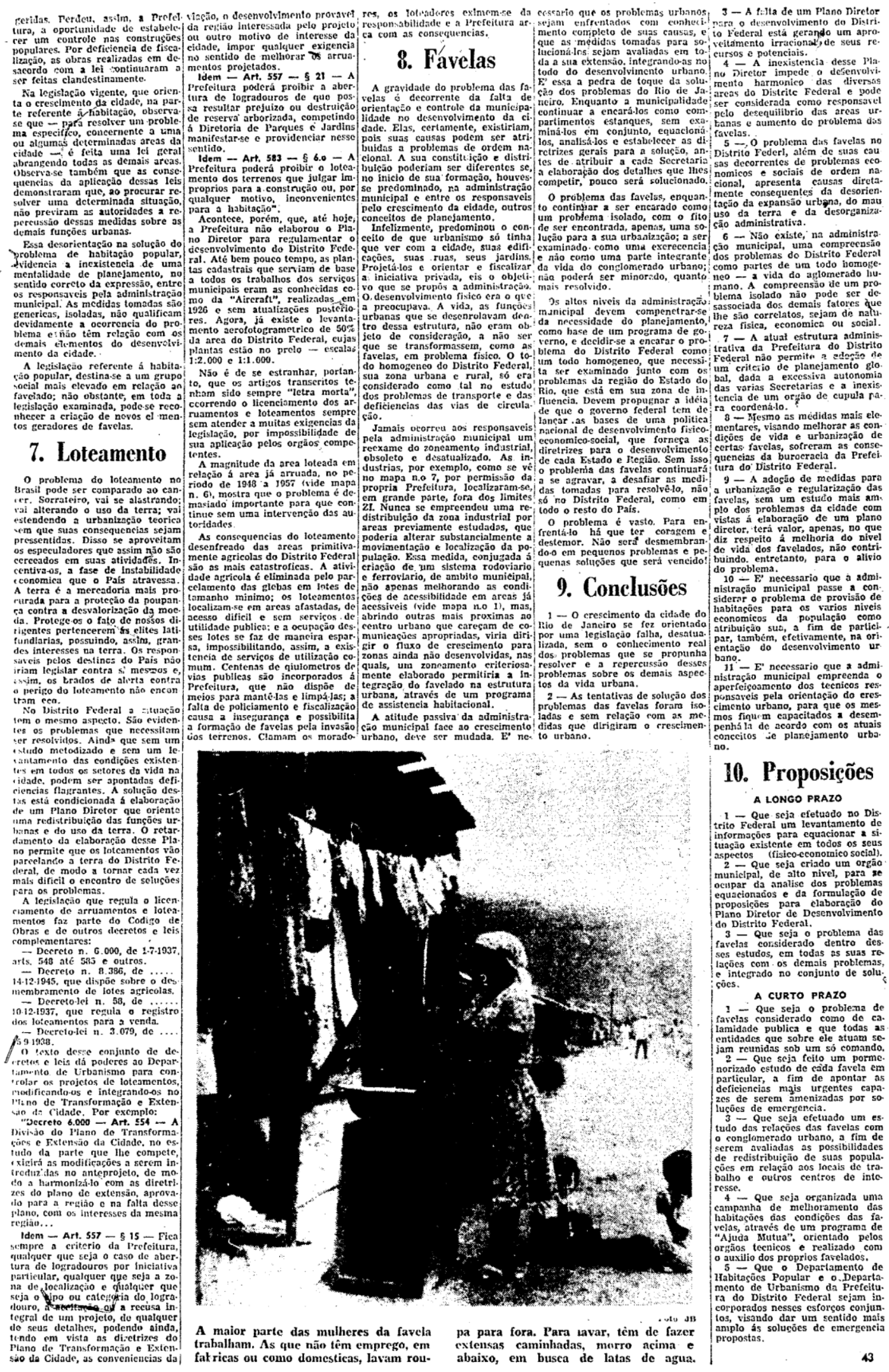

[Digite texto] 


\section{ANEXO C}

\section{AS MÚLTIPLAS INTERVENÇÕES DE INSTITUIÇÕES GOVERNAMENTAIS E RELIGIOSAS NAS FAVELAS DURANTE 1941-1980}

\section{O Relatório Moura, 1940}

Em novembro de 1940, Dr. Vitor Tavares de Moura, diretor do Albergue da Boa Vontade, apresenta ao Secretário Geral de Saúde do Governo Henrique Dodsworth um plano para o estudo e solução do problema das favelas.

O Estudo Moura foi baseado na premissa de que faltavam os dados corretos para chegar a uma solução. Daí a grande preocupação no relatório, com dados os mais detalhados e mais precisos possíveis. Nesse relatório, quando chegava a prever o trabalho prático que deveria ser executado, sugeria os locais para construir casas "modestas e higiênicas" aquelas áreas muito pouco habitadas que separavam os bairros entre si. Isto enfeitaria tais zonas e depois, com a evolução da cidade, aconteceria como em todas as grandes cidades do mundo, os tipos de casas modestas iriam dando lugar a melhor construção, enquanto que os mais humildes se encaminhariam para a periferia da cidade.

O Relatório Moura sugeria ações preventivas:

a) O controle de entrada no Rio de Janeiro de indivíduos de baixa condição social;

b) O recâmbio de indivíduos de tal condição para os seus Estados de origem;

c) A fiscalização severa quanto às leis que proíbem a construção e reconstrução de casebres;

d) A fiscalização dos indivíduos acolhidos pelas instituições de amparo;

e) Promover forte campanha de reeducação social entre os moradores da favelas, de modo a corrigir hábitos pessoais de uns e incentivar a escolha de melhor moradia;

E sugeria ações realizadoras: 
a) "Casas provisórias, pelo menos do tipo mínimo permitido pela lei, serão imediatamente construídas e para elas transferidos os moradores dos casebres, tendo em vista as suas condições de saúde, de trabalho e de defesa contra a varíola, difteria, doenças do grupo colitífico, além de inspeção torácica e apurações de conduta social."

A Comissão que surgiu a partir da proposta de Vitor Moura propôs, no seu relatório, que se promovesse uma "forte campanha de reeducação social entre os moradores das favelas, de modo a corrigir hábitos pessoais de uns e incentivar a escolha de melhor moradia."

\section{Os Parques Proletários, 1942}

O governo inicia a concretização do um plano que eventualmente deveria abrigar mais de 300.000 habitantes. Moradores eram removidos das áreas consideradas insalubres para os chamados Parques Proletários como por exemplo, o Parque Proletário da Gávea ou Parque No 1 e o Parque Proletário do Caju.

\section{Fundação Leão XIII, 1947}

Encabeçado por D. Jaime de Barros Câmara, um setor expressivo na Igreja preocupado com os avanços dos comunistas nas favelas procura as autoridades federais, propondo a criação de uma fundação que atuasse nas favelas. O governo federal encampa a déia: "E necessário subir o morro, antes que dele desçam os comunistas."

A finalidade da instituição em seus estatutos era:

a) "dar assistência material e moral aos habitantes dos morros e favelas do Rio de Janeiro."

Para operacionalizar esta proposta, a Fundação Leão XIII propôs-se:

b) a manter "escolas, ambulatórios, creches, maternidades, cozinhas e vilas populares."

Segundo a Fundação, "O povo, quando bem orientado, tem capacidade de resolver seus problemas", mas é necessário "dar às populações faveladas o sentido moral da vida e criar-lhes o senso de responsabilidade."

Por sua vez, a Fundação Leão XIII achava necessário ganhar "a confiança dos favelados na base da educação social, com um seguro 
critério de sinceridade. Estabelecer no coração da favela um Centro Social que atenda às necessidades de saúde, educação.". Assim, seria necessário que fosse planejada uma norma de reeducação e adaptação (...) com a disciplina, com o espírito de solidariedade e com o respeito às opiniões alheias.

A Fundação Leão XIII considerava que seu programa pretendia "dar orientação prévia para a urbanização"; e "a participação do povo seria sempre possível de ser obtida, através de organizações locais". Nesse sentido, achava que "as associações (de moradores) desenvolvem iniciativas capazes de mitigar, se não puder resolvê-los, os problemas que angustiam as famílias da favela". Assim, "a maneira mais acertada e possível de resolver o problema das favelas" seria com "o dinheiro e trabalho do povo".

\section{Cruzada São Sebastião, 1955}

Liderada por D. Helder Câmara, bispo auxiliar da igreja católica, propõe a construção do conjunto habitacional do Leblon chamado "Cruzada São Sebastião" que tinha por finalidade:

a) dar assistência material e moral à população favelada através da manutenção de escolas, ambulatórios, creches, maternidades, cozinhas e vilas populares;

b) dar solução racional, humana e cristã ao problema das favelas do Rio de Janeiro.

Para tanto, traçou como objetivo desenvolver "uma ação educativa de humanização e cristianização no sentido comunitário, partindo da urbanização como condição mínima de vivência humana e elevação moral, intelectual, social e econômica.

Os assistentes sociais da Cruzada de São Sebastião "procuravam conscientizar moradores acerca do "valor moral e social do Conselho de Moradores." A Cruzada de São Sebastião, por sua vez, achava que a urbanização seria condição mínima de vivência humana e elevação moral, intelectual, social e econômica."

O objetivo dos encontros promovidos pela Cruzada São Sebastião era "o estudo em comum dos problemas do conjunto, necessidades e aspirações dos moradores, para, através daí, leva-los a descobrir os recursos ao seu alcance, (relacionando-os com as necessidades existentes), planejar a solução dos problemas e melhorias a empreender ou recursos a criar". 


\section{O Relatório SAGMACS, 1958}

O estudo Aspectos Humanos da Favela Carioca, uma análise sócio-econômica elaborada pela Sociedade de Análises Gráficas e Mecanográficas Aplicadas aos Complexos Sociais - SAGMACS, foi encomendado pelo Estado de São Paulo, levou dois anos para ser concluído e foi efetuado por uma equipe de mais de 20 técnicos. Publicado no próprio Estado de São Paulo, em abril de 1960, como suplemento especial, teve sua orientação imprimida principalmente pelo Padre Louis Joseph Lebret e José Arthur Rios, com a colaboração de Carlos Alberto de Medina.

Segundo o relatório, "O sentimento de independência, o senso de responsabilidade seriam passos importantes para a educação dos favelados"; e "o papel das autoridades é esse: orientar e dar apoio moral a essa gente, dar-Ihe responsabilidade moral".

Descrevendo as atividades da Fundação Leão XIII, no entanto, o grupo SAGMACS percebeu que, quando os moradores pensaram em "construir casas de alvenaria, seus líderes acabavam aconselhando-os a não fazê-lo porque, se vier a urbanização da favela, pouco deverão aproveitar do material demolido, ao passo que, sendo seus barracos de tábuas, poderão aproveitá-las e construir novamente em outro lugar. A urbanização tornou-se uma espécie de bicho-papão do favelado."

O grupo SAGMACS achava que nem d Fundação Leão XIII, nem a Cruzada São Sebastião poderiam resolver a questão da favela, e que a solução "deve ser procurada pelo próprio favelado". Nesse sentido, dever-se-ia "confiar a ele a tarefa de sua própria recuperação." As sociedades de melhoramentos que fossem desenvolvidas deveriam ser "imunes à influência política". Dessa maneira, as autoridades poderiam "delegar tarefas, desobrigando-se de encargos custosos e de reduzida eficácia".

\section{SERFHA, 1958}

Propõe o Relatório SAGMACS, nas suas recomendações, que seja formulada uma política mais flexível em relação às favelas, onde 0 SERFHA (Serviço Especial de Recuperação de Favelas e Habitações Anti-Higiênicas) seria o órgão naturalmente indicado para implementá-la. 
Quase coincidindo com a criação da Cruzada São Sebastião, o governo do Distrito Federal instituiu o SERFHA, nos fins do ano de 1956. Inicialmente sem recursos, o SERFHA funcionou, na realidade, apenas apoiando iniciativas da Fundação Leão XIII e da Cruzada São Sebastião.

Para o estudo do grupo SAGMACS, seria na organização de "grupos auto-suficientes que radicar-se-ia todo o problema educacional."

\section{Ação Comunitário do Brasil (ACB), 1967}

A ação Comunitária do Brasil era parte da concretização da proposta do desenvolvimento comunitário da USAID, nas favelas do Rio de Janeiro.

Esta instituição era filial da Acción Internacional, fundada em Nova Yorque, em 1965, atuando em vários países das Américas, inclusive nos Estados Unidos. A própria ACB se define como "uma entidade fundada e dirigida por empresários, organizada em moldes empresariais e patrocinada pelo comércio e pela indústria. Seu objetivo era criar o espírito de auto ajuda entre os favelados e capacitá-los para a solução dos seus problemas com esforço próprio. Para isso, utiliza técnicos treinados dentro de uma metodologia apropriada, para motivar e assessorar a execução pelos favelados de projetos comunitários."

A ação Comunitária do Brasil tocava que as razões psicológicas da miséria, incentivadas pelos políticos desonestos (...) fazendo com que o favelado se acostumasse a receber e não lutar."

A ACB se definia como uma entidade fundada e dirigida por empresários cujo objetivo era criar o "espírito de auto-ajuda entre os favelados e capacitá-los para a solução dos seus problemas com esforço próprio, (...) a execução pelos favelados de projetos comunitários."

\section{CHISAM, 1968}

Em 1968 foi criada, a nível federal, a Coordenadoria da Habitação de Interesse Social da Área Metropolitana do Rio de Janeiro (CHISAM), responsável pelas grandes remoções de moradores até 1973. 
Subordinada ao Ministério do Interior e ao $\mathrm{BNH}$, a CHISAM foi justificada através da déia de que as favelas constituem um problema social.

As razões para a criação da CHISAM:

a) a população favelada era alienada da sociedade por causa da sua habitação;

b) a população favelada não teria os benefícios de serviços porque não pagaria impostos

c) a família favelada necessitaria de uma reabilitação social, moral, econômica e sanitária;

d) era necessária a integração dos moradores à comunidade, não somente no modo de habitar, mas também no modo de pensar e viver

e) era necessário alterar o panorama urbano deformado.

Segundo o relatório da CHISAM "a família favelada necessitaria de uma reabilitação social, moral, econômica e sanitária”.

Para aqueles que elaboraram o relatório da CHISAM, era "necessário a integração dos moradores à comunidade, não somente no modo de habitar, mas também no modo de pensar e viver."

\section{Administração do Prefeito Klabin, 1979}

Desde o início da administração do Prefeito Israel Klabin, a equipe da SDS- Secretaria de Desenvolvimento Social realizou um estudo sobre o problema: Diretrizes para o Estabelecimento de uma Política de Ação para as Favelas do Município do Rio de Janeiro que criticava violentamente não apenas o caráter autoritário das políticas anteriores, como toda a legislação que rege essas comunidades, taxando-as de coibidoras e denunciando a incapacidade, ou melhor, a incompetência de qualquer um dos órgãos responsáveis para tratar o assunto.

\section{Secretaria Municipal de Obras, FEEMA/COMLURB, 1979}

Após a retirada de várias toneladas de lixo de seis favelas na cidade, o plano da prefeitura era orientar a comunidade favelada sobre manter limpo o local e conscientizar os favelados para os problemas da sujeira. Foram utilizados apresentações de slides e esclarecimentos sobre as más condições do acúmulo de lixo e da falta de saneamento em geral.

PROMORAR E Projeto Rio, 1979 
O Ministério do Interior, através do Ministro Andreazza, anunciou o PROMORAR, demonstrando que o governo federal também estaria preocupado e atento ao problema habitacional. O PROMORAR (Programa de Erradicação de Favelas), aprovado pelo Presidente da República em 28/06/1979, visava solucionar o problema das habitações sub-humanas, as favelas e as palafitas, urbanizando-as quando possível, e erradicando-as quando fosse "caso perdido". Ficou conhecido como o Projeto Rio.

\section{Administração do Prefeito Júlio Coutinho, 1980}

Após assumir a prefeitura em 1980, Julio Coutinho daria continuidade ao projeto SDM/UNICEF iniciado na gestão de Klabin de acordo com o documento Propostas para Ação nas Favelas Cariocas.

Segundo o grupo de trabalho da Secretaria Municipal de Desenvolvimento Social/UNICEF, "a formalização de tarefas comunitárias permitirá estabelecer a responsabilidade local"; e "o planejamento de serviços básicos nas áreas de baixa renda deveria dar ênfase a programas de Divulgação e Educação e deveria incluir um componente educacional em todas as atividades técnicas."

O grupo de assessoria do Secretário de Desenvolvimento Social, Marcos Candau, no seu documento que nunca foi reconhecido como oficial, nota que "os primeiros passos concretos nessa direção seriam a legalização da propriedade de terra e a promulgação de legislação especial para as áreas faveladas no que toca ao uso e parcelamento do solo e às condições de edificações, sem o que nenhum programa de urbanização das referidas áreas será completo.

A Coordenação de Serviços Sociais, nos termos de acordo elaborado com as Associações, mencionava o compromisso das Associações de Moradores: "Contribuir para a substituição progressiva dos barracos por construções mais adequadas e cooperar, através de mobilização de trabalho, para a realização de outros trabalhos de emergência na favela - Operação Auto-Ajuda (...). Impedir a construção de novos barracos, vindo, quando necessário, a esta coordenação para o apoio policial."

A Secretaria Municipal de Desenvolvimento Social acentuava a "participação da população, quando afirmou que "o processo de desenvolvimento enfatiza o significado da participação na definição de necessidades específicas, na adaptação de recursos e na organização de esforço humano para servir tais necessidades." 


\section{ANEXO D - Documentos - REMI E SERSE ${ }^{95}$}

SERVICO PUBBLICO FEDERAL

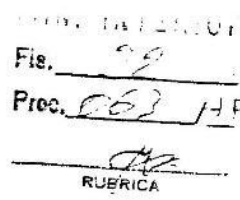

Processo n $\mathrm{n}^{\circ}$ 063/REMI/RJ/79

Tomada de Contas da Representa ção do Ministério do Interior no Rio de Janeiro - K E M I

Exercício de 1978

Tendo sido expedidos os Certificado e Relatório de Auditoria ( $f 1 s .17 / 21$ ), está o processo en condiçōes de ser subme tido à elevada consideração do Senhor Ministro para o pronunciamen to previsto no art? 82 do Decreto-Lei 200/67, e posterior encami nhamento ao Egrégio Tribunal de Contas da União.

A consideração do Senhor Inspetor-Geral de Finanças. $\mathrm{UI} / \mathrm{IGF} / \mathrm{DAT}$. EM/CEL/CD/1979

$$
\text { OKanoflfotolcantide CAlbuquerque }
$$

Senhor Ministro:

Submeto à consideraçāo de Vossa Excelência a Tomada de Contas da Representação do Ministério do Interior no Rio de Ja neiro - REMI, exercício de 1978, manifestando-me favoravelmente à sua aprovação de acordo com o parecer acima da Divisão de Auditoria. IGFI, $6,3,99$

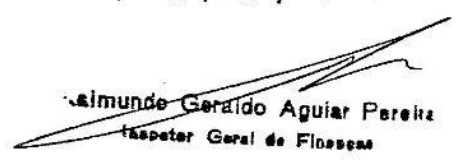

Com o parecer supra do Inspetor-Geral de Finanças que aprovo, relativo à Tomada de Contas da Representação do Minis tério do Interior no Rio de Janeiro - REMI, referente ao exercício de 1978, submeta-se o processo à consiaeração do Egrégio Tribunal de Contas da União, para fins constitucionais e legais.

MI, $06 / 03 / 79$

MAURICIO RANGEL REIS

Ninistro

95 Os documentos mais antigos ou anteriores a década de 1990 foram escaneados e apresentam problemas de impressão dos caracteres.

[Digite texto] 
049
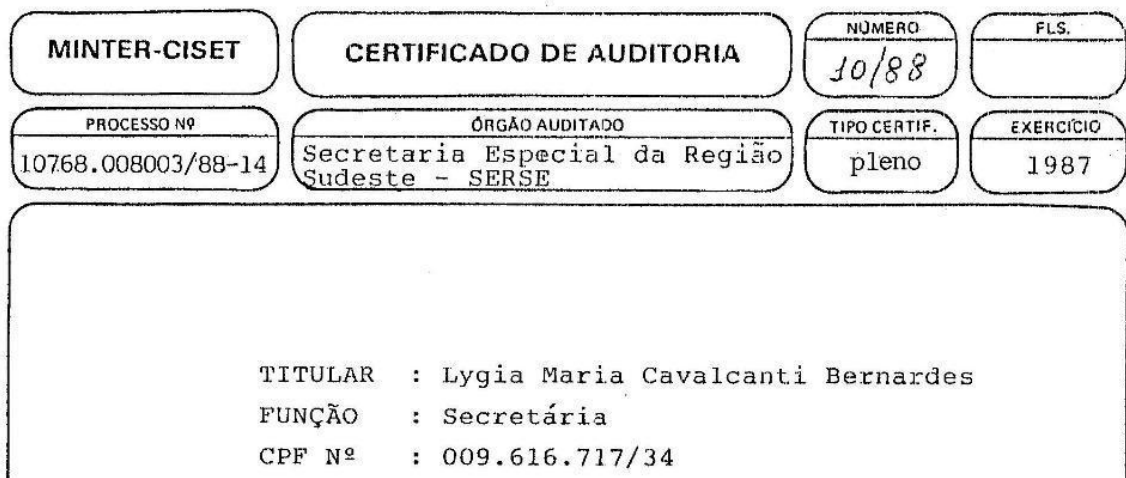

Examinamos os registros, as demonstrações contábeis e os documentos que deram origem aos elementos constantes deste pro cesso de tomada de contas dos titulares em referência e de seus agentes, nos períodos mencionados na relação anexa aos autos preseñ tes, não se verificando débito para com a Fazenda Nacional.

2 .

o exame foi efetuado por amostragem, na extensão juI gada necessária nas circunstâncias, de acordo com as normas de audi toria aplicadas ao serviço público.

3. malidades legais.

A documentação comprobatória está revestida das for 4 .

Nos registros e demonstrações contábeis foram obser vadas as normas vigentes e os princípios de contabilidade geralmen. te aceitos, aplicados de maneira uniforne em relação ao exercício anterior.

5. En face dos exames realizados, cerificamos a regulą ridade das contas dos responsáveis tratados na presente tomada de contas.

Brasília-DF', 23 de maio de 1988

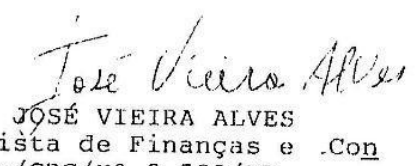

Analista de Finança $e$.Con

trole/CRC/No 2.509/DF

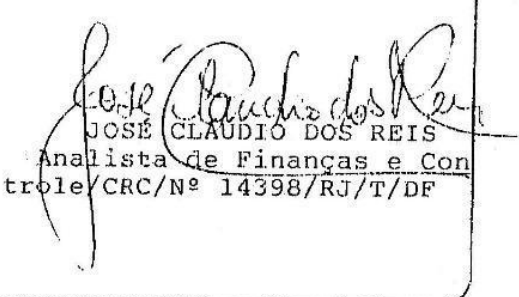

MOD. CISET 03/88 


\section{Pg. 59. Seção 1. Diário Oficial da União (DOU) de $11 / 08 / 1992^{96}$}

(Grupo II - Classe III)

TC $-575.661 / 90-9$

Pelo expediente da fl.1, a Delegacia do Tesouro Nacional no Rio de Janeiro comunica a este Tribunal que deixou de levantar a tomada de contas extraordinária da Secretaria Especial da Região Sudeste - Serse, referente ao período de 01.01 a 15.02.89, extinta pela Lei no $=7.731 / 89$, tendo em vista o que dispõe o item 1.3 da IN/STN nำ16/88.

Na sessão de 20 de novembro de 1991, este Tribunal, ao acolher, o VOTO que proferi, decidiu converter o julgamento do presente processo em diligência, a ser realizada por intermédio da CISET competente, para a Delegacia do Tesouro Nacional promovesse o levantamento, no prazo de 15 (quinze) dias, da Tomada de Contas Extraordinária da extinta Secretaria Especial da Região Sudeste, relativa ao período de 01.01 a 15.02.89, de responsabilidade das Sras. Lysia Maria Cavalcanti Bernardes e Maria Pimentel Lima, e a encaminhasse ao Controle Interno para fins regulamentares.

Cientificada da decisão supra, a CISET/MAS, ao remeter cópia do parecer COAUD no 43/92, solicita ser encerrado o questionamento sobre a matéria, "no que concerne à elaboração do processo de Tomada de Contas Extraordinária", conquanto no período de 01.01 a 15.02.89 não houve a ocorrência de qualquer fato passível de registro contábil.

Os pareceres do IRCE/RJ, uniformes, são no sentido de que esta corte reexamine a decisão proferida, em razão dos argumentos apresentados pelo Sr. Secretário de Controle Interno do MAS.

A D. Procuradoria, representada nos autos pelo Sr. Procurador-Geral, Prof. Francisco de Salles Mourão Branco divergindo da IRCE/RJ, no mérito, assim se manifesta:

5. Vê-se que as alegações da CISET/MAS amparam-se na impossibilidade material de atendimento da v. decisão deste Tribunal. Observa-se, também, que a não organização da Tomada de Contas Extraordinária teve por base prescrição da norma técnica do Controle Interno. Malgrado as alegações e o posicionamento da IRCE, pensamos que o v. decisum de fis. merece ser cumprido, transformando-se o presente processo em Tomada de Contas Extraordinária, cujos fatos contábeis descritos na diligência in loco (cf. fls. 7) e demais informações contidas nos autos configuram elementos bastantes para suprir aqueles exigidos no art. 21 da Resolução TCU no 206-80, alterada e consolidada pelas de № 213-83 e 254-91.

6. Poder-se-á, então, determinar o retorno do processo à Inspetoria Regional competente, para a proposta de mérito, quanto ao julgamento das contas dos Ordenadores de Despesa, arrolados às fls. 7 , e de Encarregada do Almoxarifado, nominada às fls. 34, em caráter excepcionai e por economia processual.

7. No que tange às observações da CISET/MAS, pensamos que caberá ser a mesma cientificada acerca da orientação prevalecente neste Tribunal, forte, naturalmente, na reafirmação do conceito de gestão consagrado em diversas assentadas, ao qual, aliás, se

\footnotetext{
${ }^{96}$ Os documentos mais antigos, anteriores à década de 1990, foram escaneados e apresentam problemas na impressão dos caracteres.
}

[Digite texto] 
compadece á promoção desta Procuradoria às fls. 37/38 (cf. v.g., proc. TC 279.076/91-6, Relator; Ministro FERNANDO GONÇALVES e proc. TC,-024.997/91-9, Relator: Ministro HOMERO SANTOS, ambos na Sessão de 03-2-1992, Ata no 26/92).

É o relatório.

\section{VOTO}

A instauração da Tomada de Contas (ordinária ou extraordinária) é uma obrigação legal do Órgão de Contabilidade Analítica e visa, além do resguardo do interesse público, assegurar o direito do Ordenador de Despesa e demais responsáveis de obterem a prestação jurisdicional sobre os atos de sua gestão.

O Sr. Coordenador da COAUD argumenta, em defesa de seu pedido de reconsideração, que, "no período de janeiro de 1989 a 15 de fevereiro do mesmo ano, não houve ocorrência de qualquer fato (orçamentário, financeiro ou patrimonial) passível de registro contábil" e que "os atos praticados naquele lapso de tempo (trinta e um dias) úteis, ficaram adstritos a preparativos de desativação daquela unidade, aliás, simples escritório de representação do então Ministério do Interior.

Em diligência, in loco, efetuada pela IRCE/RJ verificou-se que:

a) o saldo de Cz\$38.591.639,23, disponível para o exercício de 1989, foi recolhido ao Tesouro Nacional através do NL 05739, de 25.04.89, portanto após um mês da extinção do órgão (16.03.89);

b) foi procedida à liquidação dos valores, inscritos em "Restos a Pagar", no valor de $\mathrm{Cz} \$$ 35.414.359,57, através de transferência para a Unidade Gestora (CISET/MINTER), conforme NL 90019/89, de 31.03.89.

Durante o período daquela diligência não foi possível obter informações quanto à destinação dos materiais em estoque no Almoxarifado, sendo que, posteriormente, a CISET/MAS informou que dito material "encontrava-se sob a guarda do Serviço da Sedec no Rio de Janeiro".

Assim, os procedimentos acima indicados, de natureza financeira e patrimonial, seria passíveis de registros contábeis, caracterizada, portanto, a gestão da coisa pública. Ademais, o encerramento das atividades de uma unidade gestora não pode se esgotar com a determinação legal de sua extinção ou desativação, requerendo que sejam adotadas todas as medidas administrativas que visem dar ao procedimento lisura e transparência, inclusive e necessariamente, o resguardo do patrimônio público. Aqui se inclui o levantamento da Tomada de Contas Extraordinária, havendo ou não no período de gestão ocorrido movimentação de recursos financeiros, mesmo que tenham de vir ao Tribunal demonstrativos em que simplesmente conste o nada a declarar.

\section{Pg. 60. Seção 1. Diário Oficial da União (DOU) de 11/08/1992}

[...] Sugere, a D, Procuradoria, que sejam os elementos constantes deste processo recebidos como Tomada de Contas Extraordinária da unidade em questão, encaminhando-se os autos à Inspetoria competente para pronunciamento de mérito. Data venia, não me parece aceitável a

[Digite texto] 
adoção deste procedimento, porquanto, além de implicar um delicado precedente para o caso de extinção de unidade gestora, os documentos (listagem do SIAFI) encaminhados apenas demonstram a inexistência de empenhos emitidos pela unidade SERSE. Por outro lado, a transferência do material permanente ou de consumo, dos saldos existentes e das obrigações assumidas devem ser objeto de certificação pelo órgão de Controle Interno.

Assim, divergindo dos pareceres, o meu VOTO é no sentido de que o Tribunal adote a decisão que ora submeto à deliberação do Plenário.

Sala das Sessões, em 29 de julho de 1992.

HOMERO SANTOS

Ministro-Relator

Proc. TC - 575.661/90-9

Tomada de Contas

PARECER

Retornam estes autos, que tratam da Tomada de Contas Extraordinária (afinai não instaurada) da Secretaria Especial da Região Sudeste-SERSE, extinta em razão dá Lei no. 7.731, de 14-02-1989.

2.A Decisão no 351/91-Plenário (cf. fls. 42) determinou DTN/RJ o efetivo levantamento dessa Tomada de Contas, que não havia sido providenciada, sob a invocação de norma da também extinta Secretaria do Tesouro Nacional, - norma essa hoje revogada, onde se previa a dispensa desse procedimento quando o dirigente não praticasse atos de gestão.,

3. O Sr. Secretário de Controle Interno do Ministério da Ação Social solicita que seja "encerrado o questionamento, no que concerne à laboração do Processo de Tomada de Contas Extraordinária" (cf. fls. 44), ante o que argui a sua Coordenação de Auditoria-COAUD), que considera não haver nada a registrar ou auditar no período de 1ำ-01-1989 até extinção da Serse, juntando-se, a propósito, informação sobre pesquisa no SIAFI acerca da inexistência de atos de gestão (cf. fls. 43/55)..

4, A instrução do processo, a cargo de zelosa IRCE/RJ, entendendo, à vista dos elementos carreados aos autos, que "não houve, ocorrência de qualquer fato orçamentário, financeiro ou patrimonial,, passível de registro contábil", propõe o reexame da questão, na forma\ proposta péla CISET/MAS.

5. Somos distinguido com a audiência solicitada pelo eminente Ministro-Relator, HOMERO SANTOS, em seu v. despacho de 24-3-1992, às fls. 59.

5. . Vê-se que as alegações da CISET/MAS amparam-se na impossibilidade material de atendimento da v. decisão deste Tribunal. Observa-se, também, que a não organização da Tomada de Contas Extraordinária teve por base prescrição da norma técnica do Controle Interno. Malgrado as alegações e o posicionamento da IRCE, pensamos que o v. decisum de fis. merece ser cumprido, transformando-se o presente processo em Tomada de Contas Extraordinária, cujos fatos contábeis descritos na diligência in loco (cf. fls. 7) e demais informações contidas nos autos configuram elementos bastantes para suprir aqueles exigidos no art. 21 da Resolução TCU no 206-80, alterada e consolidada pelas de no 213-83 e 254-91.

6. Poder-se-á, então, determinar o retorno do processo à Inspetoria Regional competente, para a proposta de mérito, quanto ao julgamento das contas dos Ordenadores de Despesa,

[Digite texto] 
arrolados às fls. 7, e de Encarregada do Almoxarifado, nominada às fls. 34, em caráter excepcionai e por economia processual.

7. No que tange às observações da CISET/MAS, pensamos que caberá ser a mesma cientificada acerca da orientação prevalecente neste Tribunal, forte, naturalmente, na reafirmação do conceito de gestão consagrado em diversas assentadas, ao qual, aliás, se compadece á promoção desta Procuradoria às fls. $37 / 38$ (cf. v.g., proc. TC 279.076/91-6, Relator; Ministro FERNANDO GONÇALVES e proc. TC,-024.997/91-9, Relator: Ministro

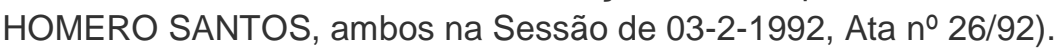

Procuradoria, em 15 de julho de 1992

FRANCISCO DE SALLES MOURÃO.BRANCO

Procurador-Geral

DECISÃO № 379/92 Plenário

I. Processo no TC-575.661/90-9

2. Classe de Assunto; III - Comunicação quanto à dispensa de levantamento de Tomada de Contas Extraordinária

3. Responsável : Lysia Maria Cavalcanti Bernardes

4, Unidade:. SERSE - Secretaria Especial da Região Sudeste Vincuiação.; ex-Minter

5. Relator: Ministro Homero Santos

6. Representante do Ministério Público; Prof. Francisco de Salles MeurãO Branco

7. Órgão de Instrução; IRCE/RJ

8, Decisão; O Tribunal Pleno, diante das razões expostos pelo Relator, DECIDE :

8,1 - conhecer do expediente do Sr. Secretário de Controlo Interno do Ministério da Ação Social como pedido de reconsideração da Decisão no 35.1/91-Plenário, de 20.11.91, para negar-Ihe acolhimento, mantendo-se no seus exatos termos aquela Decisão e fixando-se o prazo, improrrogável, de 30 (trinta) dias para o seu integral cumprimento;

8,2. alertar a CISET/MAS e a Delegacia Regional do Tesouro Nacional nó Rio de Janeiro no sentido de que:

8.2.1. é obrigatório o levantamento da Tomada de Contas Extraordinária de unidades gestoras extintas, por estarem sujeitos os seus responsáveis à jurisdição do Tribunal, vez que só poderão ser liberados de suas responsabilidades por ato desta Corte, havendo ou não movimentação de recursos financeiros;

8.2.2. observe, quanto à definição e utilização do conceito de gestão pública, o entendimento desta Corte firmado na Sessão de 19.06.91 (TC-000.786/91-1 .- Anexo V da Ata no 29/91 - Relator: Ministro Bento Bugarin), e de 03/06/92 (TC-279.076/91-6 - Relator: Ministro Fernando Gonçalves e TC-024.997/91-9 - Relator: Ministro Homero Santos, constantes, respectivamente, das Decisões no 280 e. 286 da Ata no 26/92-P) e no sentido de que a gestão não deve ser encarada exclusivamente sob o prisma financeiro e orçamentário, mas como ato que envolve aspectos contábeis, operacionais, financeiros, orçamentários e patrimoniais no gerenciamento da coisa pública, devendo obrigatoriamente ser considerados na apreciação da regularidade ou não da gestão refletida nas respectivas contas. 
9. Ata nº 36/92 - Plenário.

10. Data da Sessão: 29 / $07 / 1992$

CARLOS ATILA ALVARES DA SILVA

Presidente

HOMERO SANTOS

Ministro-Relator

\section{Pg. 202. Seção 1. Diário Oficial da União (DOU) de 30/12/1986}

Of. $216 / 86$

Secretaria Especial da Região Sudeste

EXTRATOS DE TERMÕS ADITIVOS

ESPECIE: Termo Aditivo n9 01 ao Convênio n9 017/SERSE/86 entre o MINTER, através de sua Secretaria Especial da Região Sudeste e a Secretaria de Trabalho e Ação Social do Governo de Minas Gerais, objetivando assegurar a continuidade do Programa de Pagrações Internas do MINTER.

OBJETO: O Termo Aditivo tem por objeto alterar a vigência do Convênio n9 17/SE/86 - Fita alterada a Cláusula Nona do Convênio original. Da Vigência - Estabelendo-se novo termo que expirará na data de 07.07.87.

DATA E ASSINATURAS: 19 de dezembro de 1986. Lysia Maria Cavalcanti Bernardes Secretária da SERSE. Mário Ribeiro da Silveira - Secretária da SETAS.

ESPÉCIE: Primeiro Termo Aditivo ao Convênio n9 089/SERSE/85 que entre si celebram o MINTER através de sua Secretaria Especial da Região Sudeste e a Fundação de Desenvolvimento da Pesquisa para a Aplicação dos Recursos de Administração e Acompanhamento Previstos na Programação de 1986 do POLOCENTRO para o Estado de Minas Gerais.

OBJETO: Constitui objeto do presente instrumento o aditamento ao Convênio original, alterando o seu valor e sua vigência, com base na sua Cláusula Décima Primeira. DOS RECURSOS: Fica suplementada financeiramente 7 com a importância de CZ\$525.000,00 (quinhentos e vinte e cinco mil cruzados) a Cláusula Quinta do Convênio ora aditado, cujo o valor total passa a ser de CZ\$720.200,00 (setecentos e vinte mil e duzentos cruzados): VIGÊNCIA: Fica alterada a Cláusula Décima Primeira do Convênio ora adita do apenas quanto ao prazo de vigência, que fica prorrogado até 31 de dezembro de 1987. Ficam ratificadas todas as Cláusulas e condições do Convênio original. DATA E ASSINATURAS: 18 de dezembro de 1986. Lysia Maria Cavalcanti Bernardes - Secretária da SERSE. Marcello de Vasconcellos Coelho - Secretário-Executivo da FUNDEP. ESPÉCIE: Segundo Termo Aditivo ao Convênio n9 054/SERSE/85, entre o Ministério do Interior, através da SERSE, o Governo do Estado de 
Minas Gerais, através da Secretaria de Planejamento e Coordenação Geral e a Comissão de Desenvolvimento do Vale do Jequitinhonha, objetivando dar continuidade aos Projetos de Desenvolvimento do supracitado Vale.

OBJETO: O presente Termo Aditivo tem por objeto alterar os termos da Clausula Quinta, item I e parágrafo Segundo do Convênio original, bem como da Cláusula Primeira e item I do Termo Aditivo n9 2 do Convênio n9 5:4' SERSE/85, que passa a viger com nova redação. Ficam ratificadas as de mais Cláusulas e condições do Convênio original e do seu primeiro Termo de Aditivo, assinado em 07.10 .85 e que não contrariem, implícita ou explicitamente as previstas neste instrumento. DATA E ASSINATURAS: 18 de dezembro de 1986. Lysia Maria Cavalcanti Bernardes - Secretária da SERSE.

Evandro de Pádua Abreu - Secretária da SEPLAN/MG. Humberto de Matos Reis Diretor-Geral da CODEVALE, em exercício.

ESPÉCIE: Termo Aditivo ao Convênio n9 088/SERSE/85, celebrado em 19 de dezembro de 1985, entre o Ministério do Interior, através de sua Secreta ria Especial da Região Sudeste e o Estado de Minas Gerais, através de sua Secretaria de Planejamento e Coordenação Geral, objetivando alterações no referido convênio. OBJETO: O Termo Aditivo tem por objeto compatibilizar às Cláusulas do c.,-,Evg-IIro n9 088/SERSE/85, às alterações resistentes da reprogramação aprovada pela Portaria SEPLAN/PR n9 137, de 13710.86 e prorrogar a vigência do convênio original. Fica também a referida vigência prorrogada até 31 de dezembro de 1987, podendo ser alterado mediante Termos Aditivos. DATA E ASSINATURAS: 19 de dezembro de 1986.

Lysia Maria Cavalcanti Bernardes - Secretária da SERSE. Evandro de Pádua Abreu Secretário da SEPLAN/MG.

de

\section{EXTRATO DO CONVENTO N9 457 /SERSE/86}

CONVENENTES: Ministério do Interior através de sua Secretaria Especial da Região Sudeste e o Governo do Estado de Minas Gerais, através de sua Secretaria de Estado do Planejamento.

OBJETO: Execução de projetos e atividades integrantes do POLOCENTRO Programa de Desenvolvimento dos Cerrados de Minas Gerais, relativos à implantação da infraestrutura básica complementar às ações da Reforma Agrária com base na Portaria SEPLAN/PR n9 137, de 13.10.86. RECURSOS: Lei 7.420, de 17.12.85 - Unidade Orçamentária 2802.07401833404 - Elemento de Despesa 4.3-2.2.01. EMPENHO: N9 585/00-0, de 18 de dezembro de 1986. VALOR: CZ\$ 8.225.000,00 (oito milhões, duzentos e vinte e cinco cruzados) VIGÊNCIA: O Convênio que será publicado no D.O.U. terá vigência de (01) hum ano a partir da data de sua assinatura, podendo ser alterado macb.amte Termo Aditivo, se assim convier os partes. DATA E ASSINATURAS: 18 de dezembro de 1986.. Lysia Maria Cavalcanti Bernardes - Secretária da SERSE. Evandro de Pádna Abreu - Secretária da SEPLAN/MG. EXTRATO DO CONVÊNIO NO 458/SERSE/86 CONVENENTES: Ministério do Interior através de sua Secretaria Especial da Região Sudeste e a Prefeitura Municipal de São Gotargo-MG.

OBJETO: Execução de projetos e atividades integrantes do POLOCENTRO-MG -Programa de Desenvolvimento dos Cerrados de Minas Gerais relativos à Programação constante da Portaria SEPLAN/PR N9 137, de 13.10.86. DOS RECURSOS: Lei n9 7.420, de 17.12.85 - Unidade Orçamentária Secretaria-Geral - Programa de Trabalho 2802.07401833.404 - Elemento de Despesa 4130.48. EMPENHO: N9 580/00-0, de 18 de dezembro de 1986. VALOR: CZ\$ 
175.000,00 (cento e setenta e cinco mil cruzados) VIGÊNCIA: O Convênio que será publicado em DOU, terá vigência de 01 (um) ano, a contar da data de sua assinatura, podendo ser modificado mediante Termo Aditivo. DATA E ASSINATURAS: 18 de dezembro de 1986. Lysia Maria Cavalcanti Bernardas - Secretária da SERSE. Paulo Uejo - Prefeito Municipal de São Gotargo, Estado de Minas Gerais. EXTRATO DO CONVENTO N9 459/SERSE/86 CONVENENTES: Ministério do Interior através de sua Secretaria Especial da Região. Sudeste e a Empresa de Serviços e Insumos Básicos para a Agropecuária do Estado do Rio de JaneiroSIAGRO/Rio e o Instituto Nacional de Colonização e Reforma Agrária-INCRA. OBJETO: Conjugação de esforços técnicos, materiais e financeiros entre o MINTER, SIAGRA/RIO e o INCRA em ações complementares à Reforma Agrária visando o fornecimento de insumos (corretivos, sementes, adubos, fertilizantes e outros) nos projetos' de Assentamento em Amas de Reforma Agrária do INCRA/RJ. DOS RECURSOS: Lei n9 7.420, de 17.12.85 r Unidade Orçamentaria 2802 -Programa 07401833.337 - Elemento de Despesa 4322.01. EMPENHO: NO 582/00-4, de 18.12.86. VIGÊNCIA: O Convênio será publicado no D.O.U., e terá vigência de 01 (um) ano, a partir da data de sua assinatura, podendo ser alterado mediante Termo Aditivo. DATA E ASSINATURAS: 18 de dezembro de 1986. Lysia Maria Cavalcanti Bernardes Secretária da SERSE. Paulo Alberto Schmidt - Diretor-Presidente da SIAGRO/RIO. Agostinho Guerreiro - Superintendente Regional do INCRA. VALOR: CZ\$ 350.000,00 (trezentos e cinquenta mil cruzados).

\section{Pg. 203. Seção 1. Diário Oficial da União (DOU) de 30/12/1986}

\section{[...] EXTRATO DO CONVÊNIO 460/SERSE/86}

CONVENENTES: Ministério do Interior através de sua Secretaria Especial da Região Sudeste e a Prefeitura Municipal de Guarda-M6r-MG.

OBJETO: Execução de projetos e atividades integrantes do POLOCENTRO-MG Programa de Desenvolvimento dos Cerrados de Minas Gerais, relativos Programação constante-da Portaria SEPLAN/PR n9 137, de 13.10.86. DOS RECUROS: Lei n9 7.420, de 17.12.85 - Unidade Orçamentária 1902 - Secretaria Geral - Programa de Trabalho 2802.07401833.404 - Elemento de Despesa 4120.48. EMPENHO: N9 581/00-2, de 18 de dezembro de 1986. VALOR:CZ\$ 175.000,00 (cento e setenta e cinco mil cruzados) VIGENCIA:"0 Convênio que será publicado no DOU, terá vigência de 01 (um) ano, a contar da data de sua assinatura, podendo ser modificado mediante Termo Aditivo. DATA E ASSINATURAS: 18 de dezembro de 1986. Lysia Maria Cavalcanti Bernardas - Secretaria da SERSE. Osório Severino Botelho -Pra feito de Guarda-M6r, Estado de Minas Gerais. EXTRATO DO CONVÊNIO N9 461/SERSE/86

CONVENENTES: Ministério do Interior através de sua Secretaria Especial da Região Sudeste, Prefeitura Municipal de Cabo Frio e o Instituto de Colonização e Reforma Agrária. OBJETO: Conjugação de esforços técnicos' materiais e financeiros entre o MINTER, a PREFEITURA e o INCRA, em ações complementares ã Reforma Agrária, que para efeito deste instrumento, compreendem construção de dois postos de saúde, reforma e ampliação de prédio escolar, no núcleo do INCRA em Campos Novos, Município de Cabo Frio: DOS RECURSOS: Lei n9 7.420, de 17.12.85 - Unidade Orçamentária 2802 -Programa 07401833.337 - Elemento de Despesa 4130.48. EMPENHO: N9 579/00-4, de 18 de dezembro de 1986. VALOR: CZ $\$ 1.820 .000,00$ (hum milhão, oitocentos e vinte mil cruzados). VIGÊNCIA: O Convênio que será publicado em D.O.U., terá vigência de 12 (doze) meses, a partir da data de sua assinatura, podendo ser alterado mediante Termo Aditivo. 
-DATA E ASSINATURAS: 18 de dezembro de 1986. Lysia Maria Cavalcanti Bernardes Secretária da SERSE. Alair Francisco Correa - Prefeito. Agostinho Guerreiro - Superintendente Regional do INCRA.

\section{EXTRATO DO CONVÊNIO N9 462/SERSE/86}

CONVENENTES: Ministério do Interior através de sua Secretaria Especial e o Governo do Estado de Minas Gerais, através da. Secretaria de Ciência e Tecnologia do Estado de Minas Gerais da Região Sudeste .

OBJETO: O Convénio tem por objeto a elaboração de diagn6stico da situação atual, dos recursos ambientais e do quadro antrópico da Bacia Hidrográfica do Rio das Mortes e de uma proposta de macrozoneamento da Bacia que forneça diretrizes e normas para o uso do solo e as ações de proteção ambiental, de modo a evitar a recorrência de enchentes calamitosas no próprio Rio das Mortes e no Rio Grande.

DOS RECURSOS: Lei n9 7.420, de 17.12.85 - Unidade Orçamentária 1902 Secretaria Geral Programa de Trabalho 0707043-2008 - Elemento de Despesa 3.1.3.2-00. EMPENHO: N9 578/00-2, de 18 de dezembro de 1986.

VALOR: CZ\$2.609.000,00 (dois milhões, seiscentos e nove mil cruzados).

VIGÊNCIA: O Convênio que será publicado no DOU, terá vigência de hum ano a partir da data de sua assinatura, podendo ser alterado mediante Termo Aditivo. DATA E ASSINATURAS: 18 de dezembro de 1986. Lysia Maria Cavalcante Bernardas - Secretária da SERSE. Walfrido Silvino dos Mares Guia Neto - Secretária da SECT.

(Of. n9 215/86)

Superintendência do Desenvolvimento da Região Sul

$25 / 86$

CONTRATO N 5

PARTES: SUDESUL/ C. R. ALMEIDA S.A. ENGENHARIA E CONSTRUÇÕES.

OBJETO: construção das Barragens sobre os Rios Leão e Bonito e obras complementares, compreendendo basicamente as fundações, maciço ferroso, de carregador de fundo, chaminé de equilíbrio, vertedor de soleira fixa, canal de vertedor de soleira fixa, canal de vertedor com dissipadores de compra e montagem de equipamento -energia, e demais obras civis, alem estes elementos deverão estar de acordo com o Protos mecânicos, todo projeto elaborado pela MAGNA ENGENHARIA LTDA. . CRÉDITO: O valor total estimado deste Contrato e de Cz\$ $98.285,151,79$ ( noventa e oito milhões, duzentos e oitenta e cinco mil, cento e cinquenta e um cruzados e setenta e nove centavos 900 (novecentos) dias consecutivos, contados a partir da VIGÊNCIA natura do Contrato. ASSINATURA: 22.12.86 ASSINAM: Pela SUDESUL - Francisco Jose Pereira, Superintendente Pela C.R. ALMEIDA S.A. - p.p. Marinaldo Ramos Lopes. Of". 102/86 MINISTÉRIO DAS COMUNICAÇÕES Gabinete do Ministro EDITAL No 224 /86-GM postas para a execução e exploração de serviço de 'Recebimento de proradiodiofusão sonora em onda média, na cidade de União, Estado do Piauí.

O MINISTRO DE ESTADO DAS COMUNICAÇÕES, tendo em vista o disposto no artigo 10 do Decreto nO 70.568. de 18 de maio de 1972, e de acordo com as normas estabelecidas no Regulamento dos Serviços de 'Radiodifusão em vigor, torna público que, transcorridos 45 
(quarenta e cinco) dias, contados do dia seguinte ao da publicação deste Edital no prazo de 15 (quinze)

Diário Oficial da União, estará recebendo pela proposta para a execução e exploração de serviço de dias, radiodifusão sonora, com as-características e condições que se seguem:

1. Serviço ONDA MEDIA

União-PI

2. Local

Freqüência 830 kHz

3.

4. Potência : Diurna $1 \mathrm{~kW}$

Noturna $0,25 \mathrm{~kW}$

5. Sistema irradiante Onidirecional

5.1 altura máxima $73 \mathrm{~m}$

5.2 altura mínima $\cdot 55$ In

6. Capital mínimo exigido 200 (duzentas) MOR

7. Horário de funcionamento llimitado

As demais condições deste Edital fazem parte do processo que lhe deu origem e encontram-se à disposição- dos interessados na Diretoria Regional do DENTEL, em Fortaleza-CE, situada na Avenida Estados Unidos, 2500 - Aldeota, onde seus representantes legais deverão entregar suas propostas.

Brasília-DF, 23 de dezembro de 1986.

ANTONIO CARLOS MAGALHÃES

Of. $157 / 86$

\section{Pg. 93. Seção 1. Diário Oficial da União (DOU) de 05/12/1988}

\section{Secretaria Geral}

Secretaria Especial da Região Sudeste

EXTRATO DO CONVÊNIO N9 081/SERSE/88

[Digite texto] 
CONVENENTES: Ministério do Interior, através da Secretaria Especial da Região SudesteSERSE e a Fundação Norte Fluminense de Desenvolvimento Regional- FUNMENOR. OBJETO: A) elaboração de cartilha sobre pesca visando desenvolver a pesca comunitária São João da Barra-RJ; b) capitação de mão-de-obra para agricultura em operador de tratorOlhos D'agua e Pitanqueiras, Campos-RJ; c) complementação de projeto de irrigação comunitária a no Córrego da Onça - Natividade - Porciúncula-RJ; d) organização comunitária, pequenos produtores do Córrego da Onça - Natividade-Porciúncula-RJ; e) aquisição de sementes e mudas para uso comunitário de 11 associações de pequenos produtores do Noroeste-Fluminense. DOS RECURSOS: Lei n9 7.632, de 03.12.87, Programa de Trabalho n9 07401831.253, E-reTnento de Despesa 4130,50. VALOR: CZ\$ 4.300.000,00. EMPENHO:'N9 88NE... 00605, de 25.11.88. VIGÊNCIA: 12 (doze) meses, contados, da data de sua assinatura, podendo ser alterado ou prorrogado através de Termo Aditivo, na forma da legislação vigente. DATA E ASSINATURAS: 25.11.88. Lysia Maria Cavalcanti Bernardes Secretaria da SERSE. Jose Carlos Azevedo de Menezes - Presidente da FUNDENOR.

\section{EXTRATO DO CONVÊNIO N9 82/SERSE/88}

CONVENENTES: Ministério do Interior, através da Secretaria Especial da

Região Sudeste-SERSE e a Prefeitura Municipal de Natividade-RJ, com interveniência da Delegacia Federal da Agricultura do Estado do Rio de Janeiro. OBJETO: Apoiar a produção e comercialização dos Pequenos Produtores associados da região noroeste do Estado do Rio de Janeiro, através da reforma de galpão e complementação de valor para implantação de uma fábrica de tijolos-olaria para uso comunitário. DOS RECURSOS: Lei n97.632, de 03.12.87 Programa de Trabalho 07401831.253, Elemento de Despesa 4323.01. VALOR: CZ\$ 1.300.000,00. EMPENHO: N9 00611, de 28.11.88.7

VIGÊNCIA: 06 (seis) meses, contados da data de sua assinatura, podendo ser alterado através de Termo Aditivo, na forma da legislação vigente.

DATA E ASSINATURAS: 28.11.88. Lysia Maria Cavalcanti Bernardes - Secretaria da SERSE. Murilo Alves Ribeiro - Prefeito Municipal de Natividade/RJ. Octávio Denys Neto - Delegado da DFA/RJ.

\section{EXTRATO DE TERMO ADITIVO}

ESPÉCIE: Primeiro Termo Aditivo ao Convênio n9 141/SERSE/87, celebrado entre o Ministério do Interior, através da Secretaria Especial da Região Sudeste, o Ministério da Reforma e do Desenvolvimento Agrário, através da sua Delegacia Regional no Rio de Janeiro e a Superintendência Estadual de Rios e Lagos do Rio de Janeiro. OBJETO: Acrescentar movavedação às Cláusulas Quarta, Décima e Subcláusula-Wimeira da Cláusula .Q.,e incluir a Subcláusula Terceira na Cláusula Quarta do Convênio Original. VALOR: CZ\$ 16.000.000,00. EMPENHO: N9 88NE00606, de 25.11.88....

VIGÊNCIA: 22 (vinte e dois) meses, contados da data de sua assinatura podendo ser prorrogado através de Termo Aditivo, mediante justificativa por escrito da SERLA e previamente autorizada pela. SERSE. DATA E ASSINATURAS: 25.11.88. Lysia Maria Cavalcanti Bernardes - Secretária da SERSE

Deodoro Oliveira Lima - Delegado do MIRAD-RJ. Augusto Sergio Pinto Gui-..! IffP marães Presidente da SERLA.

(Of. n9 261/88) 


\title{
Pg. 124. Seção 1. Diário Oficial da União (DOU) de 18/12/1986
}

\author{
Secretaria Especial da Região Sudeste \\ EXTRATO DO CONVÊNIO N9 383/SERSE/86
}

CONVENENTES: Ministério do Interior, através da Secretaria Especial da Região Sudeste e a Secretaria de Ciência e Tecnologia do Estado de Minas Gerais. OBJETO: 0 Convênio tem por objeto a realização da primeira parte do Programa de Recuperação e Proteção da Bacia Hidrográfica do Rio das Mortes com o intuito de iniciar o processo de recuperação ambiental dessa bacia objetivando reduzir a violência de enchentes calamitosas nesse Vale e no do Rio Grande. DOS RECURSOS: Os recursos correrão J. conta dos Recursos orçamentários consignados ao MINTER através da Lei n9 7..420 de 17.12.85, Programa de Trabalho n9 07390216.187 - Elemento de Despesa 3.1.3.2. EMPENHO:N9 00533/00 de 11.12.86. VALOR:CZ\$200.000, 00(duzentos mil cruzados).VIGÊNCIA: O Convênio que mera publicado em forma de Extrato no D.O.U., terá vigência de 08 (oito) meses, a partir da data de sua assinatura, podendo ser prorrogado mediante Termo Aditivo. DATA E ASSINATURA: 11 de dezembro de 1986. Lysia Maria Cavalcanti -Bernardes - Secretária da SERSE - Wãlfrido Silvino dos Mares Guia Neto - Secretário de Ciência e Tecnologia - Estado de Minas Gerais.

\section{EXTRATO DO CONVÊNIO N9 384/SERSE/86}

CONVENENTES: Ministério do Interior, através da Secretaria Especial da Região Sudeste e a Prefeitura Municipal de Paraty, Estado do Rio de Janeiro. OBJETO: transferência de recursos financeiros pela SERSE á Prefeitura destinados a aquisição de veículo automotor, prioritariamente, e aparelhos transceptores de radiofonia a serem utilizados pela Defesa Ci vil nos serviços de atendimento às populações situadas no Município de Paraty/RJ, nos casos de emergência em razão da Central Usina Nuclear 1, instalada, em Angra dos Reis/RJ. DOS RECURSOS: o apoio financeiro correrá á conta dos recursos orçamentários consignados ao MINTER, através da Lei n9 7.420 de 17.12.85, Unidade Orçamentária 1902 - Atividade 03811784.029, Elementos de Despesa 4130-48. VALOR:CZ\$270.000,00 (duzentos e setenta mil cruzados). EMPENHO: N9 005.WO de 11.12.86. VIGENCIA: O Convênio que será publicado no D.O.U., terá vigência de 5(cinco) anos a partir da data de assinatura, podendo ser alterado e prorrogado, mediante Termo Aditivo. DATA E ASSINATURA: 11 de dezembro de 1986. Lysia Maria Cavalcanti Bernardes - Secretária da SERSE - Edson Didimo Lacerda -Prefeito de Paraty/RJ.

\section{EXTRATO DO CONVÊNIO N9 385/SERSE/86}

CONVENENTES:Ministério do Interior, através da Secretária Especial da Região Sudeste e o Instituto Nacional de Colonização e Reforma Agrária-INCRA. OBJETO: o Convênio tem por objeto a conjugação de esforços técnicos, materiais e financeiros entre o MINTER e o INCRA, em ações complementares à Reforma Agrária, que para efeito deste instrumento, compreende: de a organização comunitária das famílias assentadas nos núcleos do INCRA em Campos Novos, Município de Cabo Frio/RJ e Imburo, Município Macaé/RJ.DOS RECURSOS: à conta dos recursos orçamentários consignados ao MINTER através da Lei n9 7.420 de 17.12 .85 Unidade Orçamentária 2802 - Programa 07.401833.337 - Elemento de Despesa 4130.44. EMPENHO:N9 00556/00 de 11.12.86. VALOR:CZ $\$ 280.000,00$ e CZ $\$ 210.000,00$ Total CZ $\$ 490000,00$ (quatrocentos e noventa mil cruzados).VIGÊNCIA:0 Convênio que será publicado no Diário Oficial da União terá vigência de 12 (doze) meses, a partir da data de sua assinatura, podendo ser alterado mediante Termo Aditivo.DATA E ASSINATURA: 12 de 
dezembro d e1986. Lysia Maria Cavalcanti Bernardes - Secretária da SERSE - Agostinho Guerreiro - Superintendente Regional - INCRA.

(Of. n9 209/86)

\title{
Pg. 124. Seção 1. Diário Oficial da União (DOU) de 18/12/1986
}

\author{
Secretaria Especial da Região Sudeste \\ EXTRATO DO CONVÊNIO N9 383/SERSE/86
}

CONVENENTES: Ministério do Interior, através da Secretaria Especial da Região Sudeste e a Secretaria de Ciência e Tecnologia do Estado de Mi nas Gerais. OBJETO: o Convênio tem por objeto a realização da primeira parte do Programa de Recuperação e Proteção da Bacia Hidrográfica do Rio das Mortes com o intuito de iniciar o processo de recuperação ambiental dessa bacia objetivando reduzir a violência de enchentes calamitosas nesse Vale e no do Rio Grande. DOS RECURSOS: Os recursos correrão J. conta dos Recursos orçamentários consignados ao MINTER através da Lei n9 7..420 de 17.12.85, Programa de Trabalho n9 07390216.187 - Elemento de Despesa 3.1.3.2. EMPENHO:N9 00533/00 de 11.12.86. VALOR:CZ\$200.000, 00(duzentos mil cruzados).VIGÊNCIA: O Convênio que mera publicado em forma de Extrato no D.O.U., terá vigência de 08 (oito) meses, a partir da data de sua assinatura, podendo ser prorrogado mediante Termo Aditivo. DATA E ASSINATURA: 11 de dezembro de 1986. Lysia Maria Cavalcanti -Bernardes - Secretária da SERSE - Wãlfrido Silvino dos Mares Guia Neto - Secretário de Ciência e Tecnologia - Estado de Minas Gerais.

\section{EXTRATO DO CONVÊNIO N9 384/SERSE/86}

CONVENENTES: Ministério do Interior, através da Secretaria Especial da Região Sudeste e a Prefeitura Municipal de Paraty, Estado do Rio de Janeiro. OBJETO: Transferência de recursos financeiros pela SERSE á Prefeitura destinados à aquisição de veículo automotor, prioritariamente, e aparelhos transceptores de radiofonia a serem utilizados pela Defesa Ci vil nos serviços de atendimento às populações situadas no Município de Paraty/RJ, nos casos de emergência em razão da Central Usina Nuclear 1, instalada, em Angra dos Reis/RJ. DOS RECURSOS: o apoio financeiro correrá á conta dos recursos orçamentários consignados ao MINTER, através da Lei n9 7.420 de 17.12.85, Unidade Orçamentária 1902 - Atividade 03811784.029, Elementos de Despesa 4130-48. VALOR:CZ\$270.000,00 (duzentos e setenta mil cruzados). EMPENHO:N9 005.WO de 11.12.86.VIGENCIA: O Convênio que será publicado no D.O.U., terá vigência de 5(cinco) anos a partir da data de assinatura, podendo ser alterado e prorrogado, mediante Termo Aditivo. DATA E ASSINATURA: 11 de dezembro de1986. Lysia Maria Cavalcanti Bernardes - Secretária da SERSE - Edson Didimo Lacerda -Prefeito de Paraty/RJ.

\section{EXTRATO DO CONVÊNIO N9 385/SERSE/86}

CONVENENTES: Ministério do Interior, através da Secretária Especial da Região Sudeste e o Instituto Nacional de Colonização e Reforma Agrária-INCRA. OBJETO: o Convênio tem por objeto a conjugação de esforços Técnicos, materiais e financeiros entre o MINTER e o INCRA, em ações complementares à Reforma Agrária, que para efeito deste instrumento, compreende a organização comunitária das famílias assentadas nos núcleos do INCRA em Campos Novos, Município de Cabo Frio/RJ e Imburo, Município Macaé/RJ.DOS RECURSOS: à conta dos 
recursos orçamentários consignados ao MINTER através da Lei n9 7.420 de 17.12 .85 Unidade Orçamentária 2802 - Programa 07.401833.337 - Elemento de Despesa 4130.44. EMPENHO:,N9 00556/00 de 11.12.86. VALOR:CZ $\$ 280.000,00$ e CZ $\$ 210.000,00$ Total CZ\$490-000,00(quatrocentos e noventa mil cruzados).VIGÊNCIA:0 Convênio que será publicado no Diário Oficial da União terá vigência de 12 (doze) meses, a partir da data de sua assinatura, podendo ser alterado mediante Termo Aditivo. DATA E ASSINATURA: 12 de dezembro d e1986. Lysia Maria Cavalcanti Bernardes - Secretária da SERSE - Agostinho Guerreiro - Superintendente Regional - INCRA.

(Of. n9 209/86) 